\title{
Rosamaria Barbara
}

\section{A DANÇA DAS AIABÁS}

Dança, corpo e cotidiano das mulheres de candomblé

Tese de Doutorado em Sociologia apresentada ao Departamento de Sociologia da Faculdade de Filosofia, Letras e Ciências Humanas da Universidade de São Paulo, sob orientação do Prof. Dr. Reginaldo Prandi. 


\section{Rosamaria Susanna Barbara}

\section{A DANÇA DAS AIABÁS}

Dança, corpo e cotidiano das mulheres de candomblé 


\title{
Resumo
}

Este trabalho trata do complexo processo ritual do candomblé, que é individual e coletivo. Através do processo que leva o fiel a se aproximar ao candomblé, o indivíduo é conduzido a viver intensamente no próprio corpo a experiência religiosa que o levará à transformação do sofrimento e da dor até um novo renascimento na força e na alegria de viver. O processo é corporal, é o corpo que sente e que conhece por meio da ampliação das percepções sensoriais. $O$ fiel é levado assim a ter confiança nas suas sensações porque trata-se de um outro tipo de conhecimento, um conhecimento corporal, fundamentado no corpo e na valorização da própria experiência de vida. Esse processo levará à iniciação e à possibilidade de dançar no rito público do candomblé. A dança, que é dança de transe, adquire um duplo papel: de um lado dá-se a demonstração da experiência mística do fiel na transformação interior, do outro, por meio dos passos das coreografias, conta a história mítica e revela a visão de mundo do grupo. A pesquisa foi desenvolvida com uma metodologia fenomenológica e realizada em um dos terreiros mais antigos de Salvador, no qual por tradição a chefia sacerdotal é transmitida por via feminina.

\section{Riassunto}

Questa ricerca vuole mostrare il complesso processo rituale del candomblé che è individuale e sociale. Attraverso il processo che induce il fedele ad avvicinarsi al candomblé, la persona è portata a vivere intensamente nel proprio corpo l'esperienza religiosa che lo condurrà attraverso la trasformazione della sofferenza e del dolore ad una nuova ri-nascita nella forza e nella gioia della vita. Il processo è corporeo, infatti è il corpo che sente e che conosce attraverso l'ampliamento dei sensi. Si spinge così il fedele ad avere fiducia nelle sue sensazioni perché si tratta di un altro tipo di conoscenza, una conoscenza corporea, fondata nel corpo e nel dar valore alla propria esperienza di vita. Questo processo porterà all'iniziazione e alla possibilità di danzare nel rito pubblico del candomblé. La danza che è danza di trance assume così un duplice ruolo: da una parte è la dimostrazione dell'esperienza mistica del fedele e della trasformazione interiore, dall'altra attraverso i passi delle coreografie racconta la storia mitica e la visione di mondo del gruppo. La ricerca si basa su una metodologia fenomenologica e si è svolta in uno dei terreiros più antichi di Salvador, dove per tradizione la reggenza è trasmessa per via femminile.

\begin{abstract}
This research aims to show the complex ritual process of the Candomble, which is basically an organic one and consequently individual and social. Through the process which induces the believer to approach the Candomble the person is brought to live deeply in his own body the religious experience which will bring him to the transformation of suffering and pain to a re-birth into the strength and happiness of life. This process is a corporeal one - in fact, it is the body who feels and knows through the amplification of the corporeal senses. The believer is conducted to take confidence in those sensations because it is a matter of another kind of knowledge, a corporeal knowledge, based on the body and in giving value to one's own life experience. This process will bring the believer to the initiation and to the possibility of dancing in the public ritual of Candomblé. The dance which is a trance dance has a double role: in one way it is the demonstration of the mystical experience of the believer and of the inner transformation, on the other way, through the choreographic movements, it tells about the mythic history and the vision of the world of the believer. The research is developed with a phenomenological methodology and has been carried out in one of the most old terreiros of Salvador, in which by tradition the regency is transmitted trough feminine line.
\end{abstract}


Para todas as mulheres que dançam 


\section{Sumário}

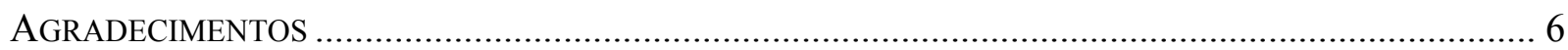

INTRODUÇÃO

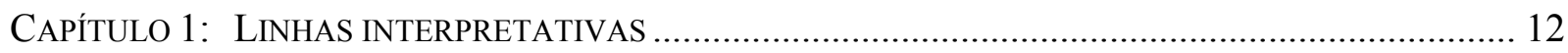

CAPÍTULO 2: MÃE ÁfriCA, MULHERES NEGRAS: MÃES E SACERDOTISAS ....................................... 23

2.1. Questões preliminares sobre o papel feminino ................................................................ 23

2.2. O terreiro Axé Opô Afonjá, o contexto da pesquisa, ...................................................... 29

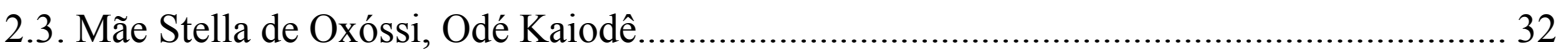

2.4. Uma quarta-feira no Axé Opô Afonjá............................................................................. 34

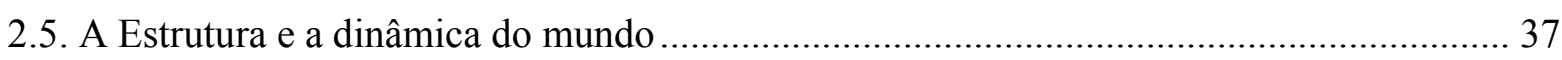

CAPÍTULO 3: A EXPERIÊNCIA DE UMA PESQUISADORA NUM TERREIRO DE CANDOMBLÉ:

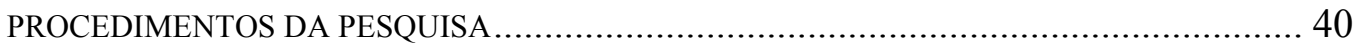

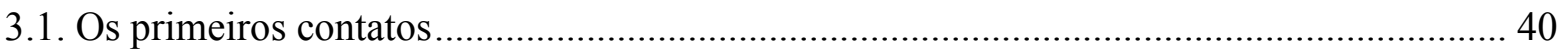

CAPÍtUlo 4: A CENTRALIDAdE EXISTENCIAL E O CORPo COMO FORÇA VITAL ............................... 52

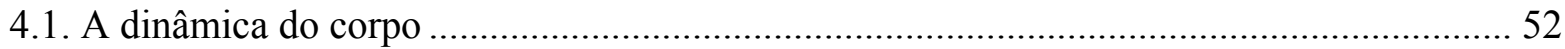

4.2. O sofrimento paralisa a vida: a falta da presença................................................................ 70

4.3. O orixá se aproxima: sensações e emoções......................................................................... 77

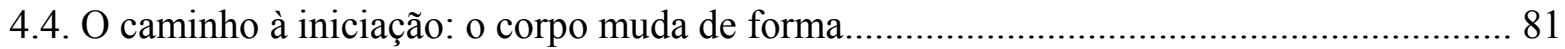

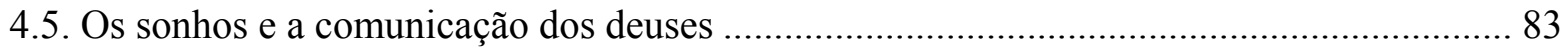

4.6. A construção da pessoa e a dinâmica do equilíbrio ............................................................ 87

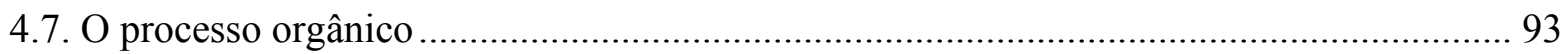

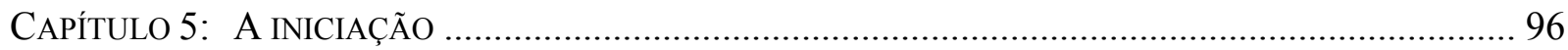

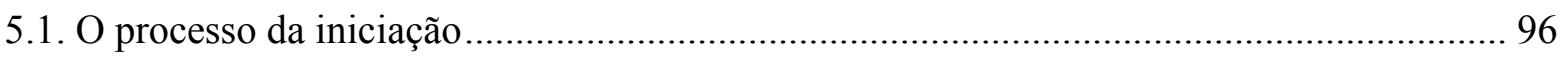

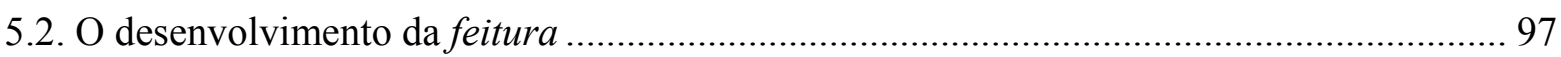

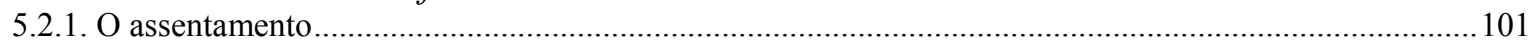

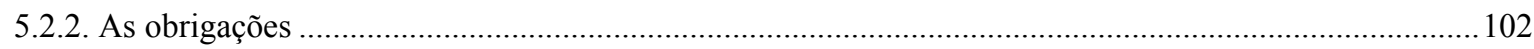

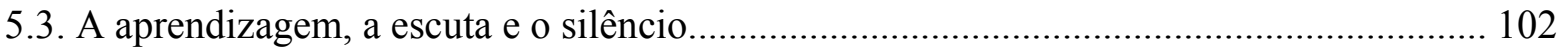

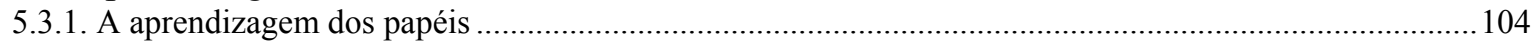


CAPÍTULO 6: A EXPERIÊNCIA DO TRANSE E O CORPO MÍSTICO .................................................... 105

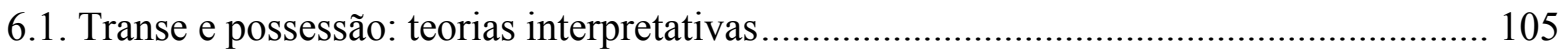

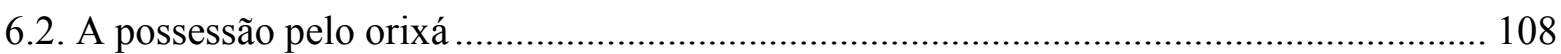

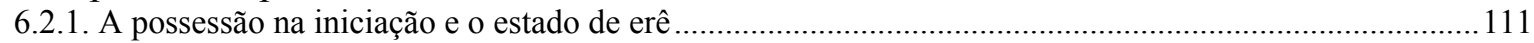

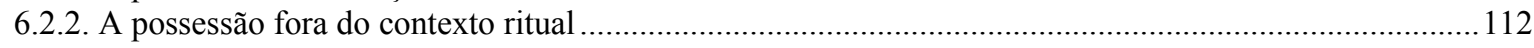

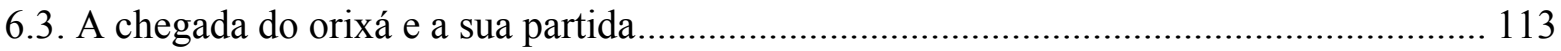

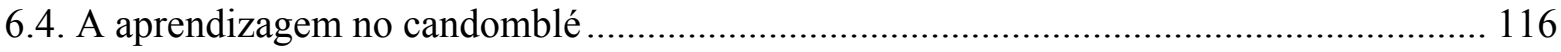

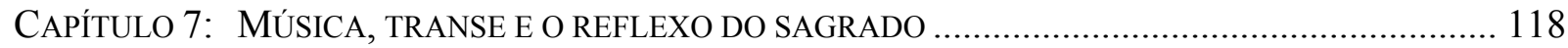

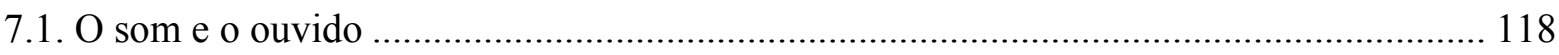

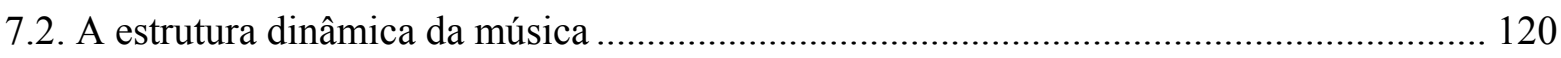

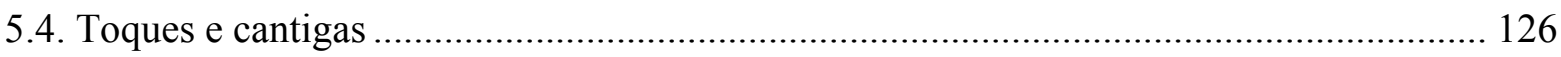

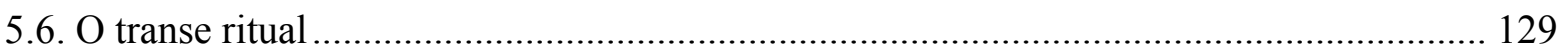

CAPÍTUlO 8: A DANÇA DAS AIABÁS E O CORPO COMO EXPERIÊNCIA SOCIAL E RITUAL.................. 132

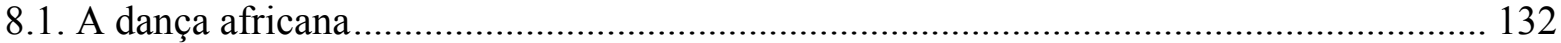

8.1.1. A atitude do corpo e a interpretação estética nativa da dança no candomblé ............................................134

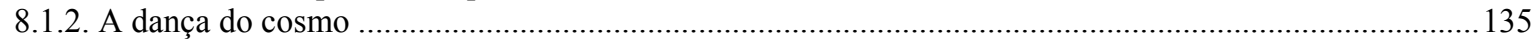

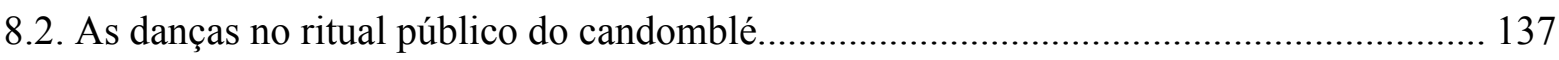

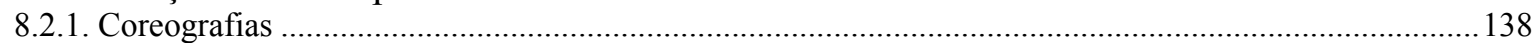

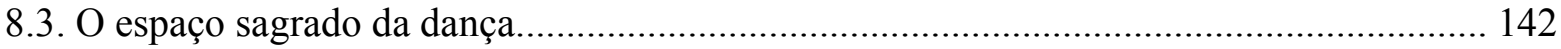

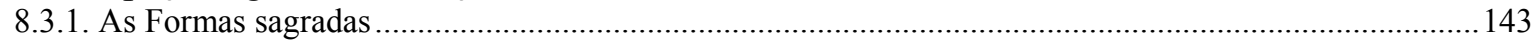

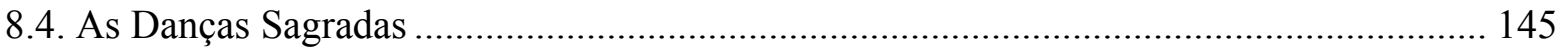

8.4.1. A descriçãa da dança das Aiabás: as frases corêuticas .......................................................................... 147

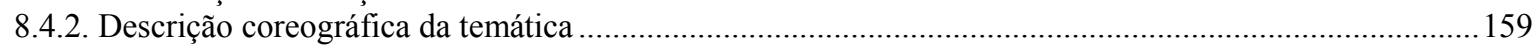

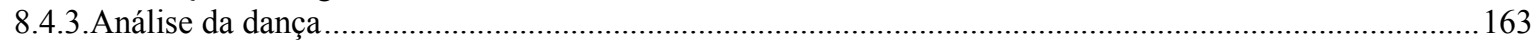

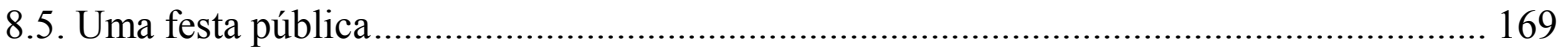

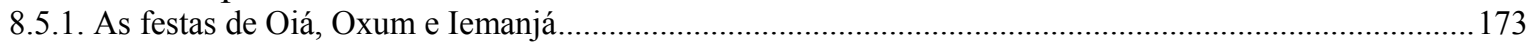

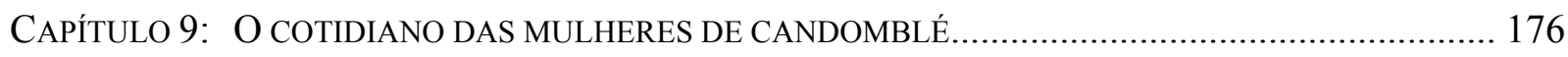

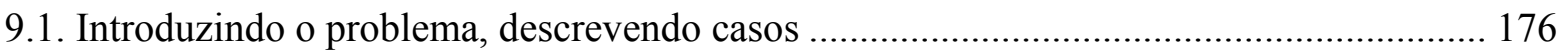

9.2. As mulheres como seres-no-mundo: o valor da experiência........................................... 182

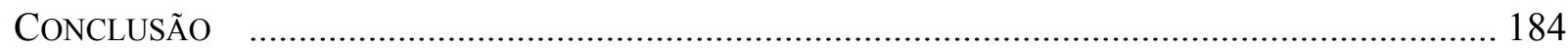

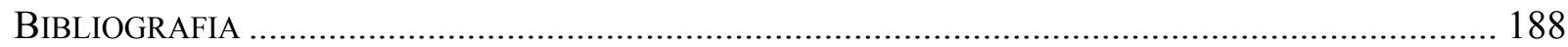




\section{Agradecimentos}

Sou grata ao Curso de Pós-Graduação em Sociologia da Universidade de São Paulo, pelo ambiente intelectual estimulante, e ao Prof. Dr. Reginaldo Prandi, meu orientador, sem cuja ajuda e confiança eu não teria concluído esta tese.

Devo agradecer o apoio do CNPq, Conselho Nacional de Desenvolvimento Científico e Tecnológico, que concedeu meios necessários para a execução da tese por meio de bolsa de doutorado.

Sou também devedora a muitas outras instituições e pessoas que me ajudaram das mais diversas formas, as quais quero citar em agradecimento:

A comunidade toda do Axé Opô Afonjá, e, particularmente, muito de seus integrantes. Primeiramente a querida Mãe Stella de Oxóssi, ialorixá do terreiro, que me permitiu a experiência decisiva de morar em sua comunidade, abrindo-me generosamente as portas de um dos principais terreiros de Salvador. Também a ebômi Ivalda, Elpidia e Mãe Aida, pelo afeto e carinho com que me acolheram e me ajudaram. A ebômi Cleo, Vera e Mariana pelas nossas conversas;

A Prof ${ }^{a}$ Dr $^{\mathrm{a}}$ Teresinha Bernardo, da PUC-SP, por sua grande generosidade, pela acolhida em sua casa e pelas sugestões preciosas; o Prof. Dr. Fábio Leite, da USP, pelos valiosos conselhos. Ambos compuseram a minha banca de qualificação;

Os Profs. Drs. Miriam Rabelo, Carlos Espinheira, Angela Lühning, todos da UFBA, e a Prof ${ }^{a}$ Luisa Faldini Pizzorno, da Universidade de Gênova, pelo diálogo que mantiveram sempre aberto;

Mãe Beata de Logum Edé, do Ilé Logum Edé Alakei Koysan, pelos preciosos conselhos que me permitiram entender melhor o comportamento no candomblé, pela disponibilidade frente às minhas perguntas e, sobretudo, pela confiança e pelo afeto que nos liga; Pai Zequinha, grande cantor dos Filhos de Gandhi; Mãe Anália, da Irmandade da Boa Morte, de Cachoeira, pela grande 
confiança em mim depositada; e Mãe Nancy (Ceci) de Oxalá, do Ilê Axé Opô Aganju, de Lauro de Freitas, grande figura, grande contadora de histórias;

Pai Armando de Ogum, babalorixá do Candomblé Casa das Águas, de São Paulo, e meu colega de doutorado, pela amizade e apoio; Gamo Paz, do Gantois, pela ajuda na parte musical; e Mãe Terezinha, do Ilê Axé Oxumarê, outra grande contadora de histórias;

Os colegas da Fundação Pierre Fatumbi Verger pela inestimável colaboração na consulta a fontes da pesquisa;

Alessandro e meus amigos Carlo e Jassi, que me acompanharam nas minhas peregrinações, e especialmente o Prof. Giuseppe Cosma, grande amigo e conhecedor de religião e filosofia;

Luciano Gomes Freire, pela ajuda na revisão dos originais, e minha querida amiga Giliola Vesentini, pelas belas ilustrações;

Meu marido Fúria e minha mãe, que me apoiaram durante toda a redação da tese, e meu avô Stefano, que apesar da velhice me incentivou até o final deste trabalho.

Muito obrigada a todos. 


\section{INTRODUÇÃO}

Este é um estudo sobre a dança no candomblé. Ao longo da pesquisa de campo na Bahia, que durou quatro anos, enquanto me familiarizava com os rituais e com a comunidade, o que aconteceu em diferentes etapas, com as minhas visitas ao terreiro me fazendo cada vez mais próxima dos membros da comunidade, fui percebendo o papel fundamental do corpo e da dança na religião dos orixás. A dança, como pude constatar, não é uma simples e fria repetição automática de gestos ou de coreografias, mas uma nova experiência do corpo, um corpo que passou por todo um processo ritual.

O presente trabalho visa a compreender a experiência do corpo no candomblé, o processo que leva à dança de transe e, especificamente, a relação que as mulheres conseguem construir com os próprios corpos ao longo do processo iniciático.

Concentrei a pesquisa no universo feminino, pois é gritante sua superioridade numérica em relação aos homens, assim como é notória sua "autoridade" no terreiro de candomblé no qual meu trabalho foi desenvolvido — o Axé Opô Afonjá —, assim como em muitos outros terreiros visitados. A líder do Axé Opô Afonjá tem sido sempre uma mulher, embora também existam no terreiro homens iniciados, desde o tempo da fundadora, Mãe Aninha Obabii. Foi a atual mãe-desanto, Mãe Stella de Oxóssi, que permitiu a entrada de homens na roda-de-santo ${ }^{1}$. A propósito, uma velha iniciada me disse: "Na minha época, eu nunca vi homem dançando".

$\mathrm{Na}$ Casa Branca do Engenho Velho², o terreiro mais antigo de tradição queto na Bahia, a iniciação para receber o orixá em transe permanece ainda exclusiva para as mulheres, e, em

\footnotetext{
${ }^{1}$ A roda é formada na primeira parte do ritual público do candomblé, quando as filhas e os filhos-de-santo dançam em círculo, criando um espaço sagrado onde irão "descer" os deuses convidados para a festa.

${ }^{2}$ A Casa Branca do Engenho Velho, cujo nome oficial é Ilê Ianassô, é o mais antigo candomblé da nação queto. Situado na avenida Vasco da Gama, em Salvador, foi fundado por antigas sacerdotisas nascidas na África. Sobre a sua história, ver Lima da Costa (1977), Verger (1981), Prandi (1991a).
} 
outros terreiros, como o de Oxumarê $\hat{\mathrm{B}}^{3}$, a entrada na roda é proibida aos homens, como pudemos observar in loco e nos foi explicado no próprio terreiro.

Pessoalmente, o fato de eu ser mulher também contribuiu para que eu delimitasse a pesquisa a partir de um recorte de gênero, o que me ajudou muito no acesso ao terreiro, permitindo, depois de muito tempo, a intimidade e cumplicidade com muitas das sacerdotisas com as quais tive maior aproximação, e facilitou minha participação em atividades de obrigação feminina, como a preparação das comidas para as festas dos orixás ${ }^{4}$. A cozinha de fato é um dos lugares mais sagrados do terreiro, e é sobretudo feminina.

Ao longo do trabalho de campo, pude perceber toda uma especificidade do discurso das mulheres, compartilhado e transmitido através de um itinerário feminino que se fundamenta em um "sentir" e um "perceber". A força das emoções, as inquietações e os conflitos das mulheres têm uma gramática própria que é transmitida pela família e pelas redes de sociabilidade, em geral. Existe um compartilhar de sentimentos e emoções que se dá entre as mulheres e que pode ser vivenciado em momentos especiais da vida do terreiro.

Por trás da tranqüilidade, do equilíbrio e da dignidade das sacerdotisas, há, na maioria dos casos, mulheres negras que sofreram e sofrem por sua situação econômica, afetiva e racial, mas que souberam e sabem inventar novas estratégias de sobrevivência.

Uma vez que as mulheres necessitam trabalhar num sistema social que bloqueia e freia seus interesses, sentimentos e objetivos, elas conseguem desenvolver meios diferentes de ver, sentir, e agir que parecem ser mais "intuitivos" e não "sistemáticos", que lhes permite sobreviver mais facilmente (Rosaldo, Lamphere, 1979).

Ao longo do processo ritual, as sacerdotisas adquirem uma sabedoria sobre o corpo e através do corpo que as ajuda e as fortalece no desempenho de tarefas cotidianas; esse processo, abre a possibilidade corporal de criar e orientar novas maneiras de viver. A experiência da fé transborda na força e alegria evidenciadas nos rituais através do grande cuidado para e com o orixá, experiência que a condição histórica das mulheres negras trazidas ao Brasil como escravas não conseguiu abalar. As mulheres afro-descendentes continuam no candomblé a cultuar suas divindades, continuam a louvar as águas, continuam, enfim, praticando os preceitos das "antigas", como dizem as velhas sacerdotisas, dando força a si mesmas e conselhos a quem as procuram 5 (Landes, 1967; Verger, 1985; Bernardo, 1986; Drewal, 1992; de Azevedo, 1993; Lawal, 1996).

Síntese e amostra do processo ritual e espiritual são as danças dos orixás que juntam o aspeto social ao aspecto mais individual: a experiência do transe. É fundamental a comunicação

\footnotetext{
${ }^{3}$ O terreiro de Oxumarê é um dos candomblés tradicionais da Bahia, hoje na quinta geração de dirigentes. Como relata Costa Lima, "o padroeiro da casa é Oxumarê, mas o dono da roça é Xangô". Também de tradição jeje-nagô, está situado na avenida Vasco da Gama.

${ }^{4}$ Minha participação no preparo da comida dos orixás estava evidentemente limitada à ajuda na limpeza das verduras e das carnes, porque a preparação dos pratos é permitida somente às sacerdotisas com atribuições específicas.

${ }^{5}$ Neste sentido destaca-se a figura de Mãe Stella de Oxóssi, líder do Axé Opô Afonjá, que, devido às suas posições contrárias ao sincretismo católico as religiões africanas, se tornou um modelo de luta político-religiosa para todos os descendentes de africanos que sofreram com a escravidão e demais seguidores do candomblé.
} 
corporal, pois o corpo não é algo diferente de mim, um meu apêndice, e sim minha experiência no mundo e algo que me orienta.

Atrás dos corpos dançantes em transe há histórias pessoais várias e diferente que mostram, através de sua postura corporal e da fluidez gestual, trajetórias e processos de vida muito diversificados. Tudo isso mudou um pouco nossos objetivos finais porque aqueles corpos místicos que dançavam com grande fluidez e doçura nos rituais noturnos, e que tínhamos procurado como foco principal de nossa pesquisa, eram corpos de mulheres com uma riquíssima e complexa bagagem de vida, que expressam a complexidade da realidade que os circunda e que eu não poderias, nem de longe, conhecer ou perceber, se não tivesse tido uma familiaridade grande com elas e a comunidade.

Usando das atitudes de disfarçar ${ }^{6}$, o que é tipicamente baiano, as mulheres de candomblé entendem a seu modo os seres humanos, se ajudam e continuam a sustentar uma tradição antiga e por muito tempo muito desprezada, que se transformou em instrumento de resistência política e fonte de identidade ${ }^{7}$. Pudemos conhecer os conflitos de uma mulher negra e pobre, numa cidade majoritariamente negra, com grandes diferenças sócio-econômicas, que tem valores contraditórios, diversos de qualquer cidade ocidental da modernidade. Tais conflitos podem servir de espelho para qualquer sociedade e, em última análise, para qualquer ser que tenha sensibilidade e vontade de "ver" e respeitar a história e a cultura do outro.

Assim, a idéia inicial de nosso projeto transformou-se um pouco depois dessa "vivência" baiana; ele foi redirecionado para a tentativa de compreender os modelos femininos encarnados e vividos através da experiência corporal.

A pesquisa desenvolveu-se em torno de três assuntos principais:

1) A experiência do corpo, fundamental na aproximação do orixá, na iniciação e na vida como um todo;

2) Os novos papéis sociais que a filha-de-santo aprende após a iniciação e a nova relação estabelecida com o cotidiano mais amigo e menos ameaçador, visto que compartilhado com os orixás;

3) As danças de transe na qual a nova identidade sagrada atua nos movimentos, dando, de um lado, às filhas-de-santo, a possibilidade de experimentar a mitologia e o tempo das origens, através do ritual e, de outro, ao público, um meio de conhecer, simultaneamente, a visão de mundo da comunidade e toda a sua arte ritual: música, cantigas, oriquis, cenografia, cores, adorno com plantas, trajes etc.

\footnotetext{
${ }^{6} \mathrm{O}$ verbo "disfarçar" usado aqui indica a intenção de alguém de se livrar de uma pergunta ou de uma situação incômoda agindo como se nada estivesse acontecendo, ou como se ninguém estivesse presente em determinada situação.

${ }^{7}$ Não quero fazer uma exaltação dessas mulheres de candomblé, que são humanas e por isso têm entre si diferença de inteligência, sabedoria e capacidade. O meu intento é conferir a essas mulheres e às suas tradições a devida importância e reconhecimento.
} 
Para uma compreensão do universo feminino no contexto religioso do candomblé, a pesquisa teve o foco ajustado, então, nas esposas de Xangô, o dono do terreiro: Oxum, Oiá e Obá, e em sua mãe Iemanjá 


\section{Capítulo 1:}

\section{LINHAS INTERPRETATIVAS}

"A mulher pode ser importante, poderosa e influente, mas parece que em relação ao homem de sua idade e de seu status social, em todo o lugar carece de poder reconhecido e valorizado culturalmente."

Rosaldo (1979: 33)

Parece que existem modelos estruturais relacionados à organização cultural e social que permitem a oposição entre uma orientação "doméstica" e os laços extradomésticos ou "públicos" da mulher que, em muitas sociedades, são primordialmente acessíveis aos homens (Rosaldo, 1979). Essa perspectiva nos permite tanto compreender as muitas características gerais dos papéis sexuais humanos, quanto identificar algumas estratégias e motivações como fonte de valor e poder acessíveis às mulheres em vários grupos humanos.

As relações desiguais dos sexos foram explicadas em termos de uma causa universal e necessária. Essas explicações derivam da sugestiva hipótese de que em alguns momento os homens tomaram o poder das mulheres (Engels, 1891), ou de uma suposta inveja dos homens diante da possibilidade reprodutiva feminina (Bettelheim, 1954), ou ainda das diferenças biológicas humanas (Bardwick, 1971) impressas nos diferentes ciclos hormonais, nas capacidades sexuais ou nas orientações emocionais, tornando a mulher mais próxima da natureza e, por isso, desordenada em sentido negativo, em comparação aos homens, que seriam mais estruturados e portanto mais próximos do pólo cultural. Tudo isso foi proposto como justificativas possíveis da subordinação das mulheres aos homens.

Provavelmente, a desigualdade universal dos papéis sexuais seja o resultado de uma conjunção de diferentes fatores profundamente envolvidos no estabelecimento das sociedades. É 
interessante observar, porém, que em alguns tipos de religião, especialmente aquelas de possessão ${ }^{8}$, a mulher adquire lugares importantes na hierarquia a ponto de vir a ser líder do culto.

Desde sempre temos relatos de uma certa preponderância das mulheres nas religiões de possessão, como na Grécia antiga com os cultos de mistério das Mênades; ou com importantes papéis sagrados, como o da adivinhação da Sibila ou da Pítia, até a África, com os cultos de Ísis ou da grande mãe da Mesopotâmia, na bacia do Mediterrâneo ou na Índia. A interpretação disso tudo sempre foi elemento de polêmica; as respostas encontradas pelos estudiosos foram sempre limitadas. Lembramos autores que apontam a sobrevivência em alguns lugares do mundo de uma religião arcaica fundamentada em divindades femininas, como Grottanelli (1991) e Eliade (1975); ou, ainda, as hipóteses de Lewis (1972; 1993); ou aquela de Martino (1961: 143-146), com o tema do "Eros precluido", um tema que procura mais reproduzir um símbolo que interpretá-lo.

Conforme as mais recentes perspectivas, como a de Saraceno (1997),os dois níveis (o biológico e o social) têm de estar em comunicação a fim de não deixar a identidade feminina fora da construção social. O corpo feminino é uma experiência e não uma identidade já alcançada. Se verdade que todas as sociedades compartilham uma distinção qualquer que abranja a corporeidade entre masculino e feminino, as sociedades a moldam com uma grande variedade, na qual o feminino e o masculino são estruturados, também, nas manifestações corpóreas, de maneiras sutilmente diferentes. A proposta da leitura fenomenológica dos fundamentos corpóreos do feminino, observáveis na teias do "corpo contado" (Pandolfi, 1989; 1991) dentro de uma análise do contexto social poderia abrir uma nova perspectiva neste assunto.

$\mathrm{Na}$ religião do candomblé as mulheres alcançam elevados graus na hierarquia, fato relatado por vários estudiosos (Landes, 1967; Verger, 1985; Woortmann, 1987; Abiodun, 1989; Bernardo, 1986) e viajantes que sempre apontaram a presença e importância das mulheres no candomblé e, em geral, na cidade de Salvador, na Bahia.

Ruth Landes, após sua viagem à Bahia em 1930, pensou ter encontrado o matriarcado ou, ao menos, um lugar no qual as mulheres ocupam um lugar de maior prestígio em relação aos homens. Suas palavras, depois uma visita ao terreiro da Casa Branca do Engenho Velho, merecem ser lembradas: "Eu conclui que era verdadeiramente um templo matriarcal em que os homens, ainda que aceitos e necessários, não passavam de espectadores" (Landes, 1967: 55). E mais adiante, em um artigo, sublinhou o poder feminino na Bahia, lugar onde as mulheres "não têm medo dos homens" (1967) e fez notar a grande quantidade de mulheres ${ }^{10}$ participantes e com

\footnotetext{
${ }^{8}$ Para a definição de possessão uso a clássica diferenciação elaborada por Rouget (1986: 32), que distingue entre transe xamânico e de possessão. O primeira é visto como uma viajem no mundo dos espíritos, o segundo, como a entrada de um espírito no corpo.

${ }^{9}$ A teoria do corpo contado baseia-se na construção de um mundo e de experiências emotivas contadas através de uma linguagem sintomatológica do corpo, fundamentada em crenças estratificadas que coletam no corpo as histórias femininas. ${ }^{10}$ Preponderância feminina devida provavelmente, entre muitos fatores, ao fato de que as sacerdotisas que fundaram
esse terreiro seriam mulheres ligadas a um culto especial de Xangô no qual participavam só mulheres.
} 
um alto grau na hierarquia nos terreiros tradicionais de nação queto ${ }^{11}$ : Casa Branca, ${ }^{12}$ Gantois ${ }^{13} \mathrm{e}$ Axé Opô Afonján ${ }^{14}$.

Apesar de ter sido justamente criticada por suas colocações sobre o homossexualismo no candomblé — percebido não como uma construção social mas como uma diferença biológica a estudiosa americana teve o mérito de ter procurado uma tentativa de subordinar o significado das distinções sexuais a uma determinação social, proposta que não foi entendida pelos autores que a criticaram sobre sua análise da questão de gênero (Herskovits, 1947; Bastide, $1960^{15}$; Motta, 1984; Ortiz, 1979; Ramos, 1942; Verger, 1985). Landes procurava uma distinção de papéis ainda hoje difícil de se pensar fora do padrão marcado no plano físico-biológico. Devemos reconhecer, no entanto, que Landes fez com que percebêssemos as diferenças de sexuais presentes no candomblé, ou seja, no contexto de uma religião iniciática, numa situação na qual os indivíduos se relacionam intensamente com o desenvolvimento dos rituais e com conhecimento do sagrado.

A predominância feminina que se nota em certos terreiros da Bahia se originou provavelmente por razões histórico-sociais que se deram na época da escravidão na Bahia. Causas que permitiram uma certa liberdade (econômica e de movimento) vividas pelas afrodescendentes e que, talvez e em parte, pudessem explicar a superação pelas mulheres de dificuldades na disputa com os homens pelo poder religioso.

Este é um dos possíveis fatores que facilitaram a constituição de uma hierarquia feminina e talvez o pano de fundo desse fenômeno possa ser encontrado numa perspectiva mais "experiencial" e no mundo enraizado no corpo.

O candomblé é uma religião fundamentada no corpo e nas suas percepções, assim como na construção de um conhecimento que se dá ao longo de um processo ritual que, por sua vez, pressupõe uma experiência corporal que abre novas perspectivas de vida, oferecendo novas orientações. Podemos pensar, então, que a experiência corporal compartilhada pelas mulheres possibilitou sua união por afinidades nos candomblés. Assim, algumas concepções simbólicas e sociais que aparecem como que para restringir suas atividades podem ser usadas por elas como base para a solidariedade e para a continuação de seus valores femininos e culturais (como a importância de ser mãe ou de cozinhar, conforme a tradição tem reforçado), permitindo uma organização simbólica especificadamente feminina.

Pelo fato de pesquisar sobre a experiência do corpo, devo esclarecer alguns pontos, quase filosóficos, que nortearam a pesquisa e inspiraram a metodologia de cunho fenomenológico.

\footnotetext{
${ }^{11}$ A nação queto é uma das tradições mais importantes da Bahia. Sobre o conceito de nação ver: Costa Lima (1977) e Verger (1981).

${ }^{12}$ A Casa Branca é o primeiro terreiro de candomblé do qual se tem notícia certa. Foi fundado por três africanas de grande importância religiosa na África. Hoje está situado na avenida Vasco da Gama, Salvador (BA).

${ }^{13} \mathrm{O}$ Gantois nasceu de uma dissidência da Casa Branca e está situado no alto do Gantois, no bairro da Federação.

${ }^{14}$ Fundado em 1910, o Axé Opô Afonjá formou-se também com a saída de alguns componentes da casa Branca, entre eles Mãe Aninha.

${ }^{15}$ Fato citado no artigo de Healey (1996).
} 
Nos seres humanos existe uma procura de sentido, um significado em âmbito físico e emocional. Como esclarece P. F. D'Arcais (1999), "fazer sentido é o nosso trabalho como ser humano (...). A necessidade de sentido é uma necessidade primária do animal ser humano".

Parece que existe quase uma necessidade biológica do ser vivente de afastar ou remover de si a dor e o sofrimento da descoberta da morte através da imaginação, e uma necessidade de dizer frases construídas culturalmente que afirmem a esperança na vida. Disso deriva a formulação de uma concepção da "natureza humana" e de uma ética diferentes daquelas que até agora fundamentaram a tradição filosófica ocidental. Diferentes tanto de uma filosofia que coloca, depois dos gregos, a racionalidade como específico do ser humano, quanto daquela que não se interessa em ver como a subjetividade é construída emotivamente na relação com o outro. Faz parte do caráter humano fundamentar-se nessa relação através de uma psique estruturada num sistema integrado de emocionalidade-racionalidade, no qual o elemento emocional desenvolve o papel de puxar o pensamento (o impulso emotivo que a racionalidade tem o dever de racionalizar). Finalmente, o lado cultural constitui-se na relação com o outro. O cultural estabelece a passagem do eu ao nós e todo este processo é enxertado pela "emocionalidade".

O pensamento clássico grego tirou a raiz dionisíaca do thimos ${ }^{16}$, a dimensão do racional e do emocional que se comungavam e se exaltavam na interioridade humana. Enfim, o começo é embasado sobre a "emocionalidade" do ser e não sobre a contemplação-indagação da realidade. Ou seja, o ser biológico dá origem ao ser cultural e esse governa o seu jeito de ser, portanto, a produção de sentido está radicada no biológico, na dinâmica emocional da "alegria do sim à vida" e da "angústia do não".

A aprendizagem na experiência da vida e nas religiões se desenvolve procurando um sentido de valor entre a dinâmica dos sentimentos primários da alegria e da angústia. A procura de um sentido originou-se dessa eterna dinâmica emocional do sim e do não da vida e substituiu os condicionamentos instintivos. Esse "sim à vida" atua em um mundo de experiências que, genericamente, visa a mostrar como as pessoas vivem seu mundo, o que nos leva a discutir as idéias de consciência e subjetividade, mas, sobretudo as de intersubjetividade e ação social. Aprofundar a idéia de experiência significa mostrar a multiplicidade, a riqueza e a criatividade da vida das pessoas que não pode ser resumida em um sistema coerente e ordenado de idéias, símbolos ou representações.

Como sugerem Alves, Rabelo e Souza,

"O caráter fluido, multifacetado e, sobretudo, indeterminado da experiência escapa tanto aos cientistas sociais, que buscam decifrar códigos operantes subjacentes às práticas, quase sempre de modo inconsciente, quanto àqueles que explicam as práticas pelas idéias ou representações expressas a posteriori pelos atores" (Alves, Rabelo, Souza, 1999: 11).

"O conhecimento através do qual se vive não é necessariamente idêntico ao conhecimento através do qual se explica a vida" (Jackson, 1996: 2).

Em uma perspectiva fenomenológica, o modelo dicotômico ocidental que coloca sujeito e objeto em dois espaços bem definido não dá conta da complexidade da experiência. Nesse

\footnotetext{
${ }^{16}$ Significa vida no sentido de "força vital", ânimo.
} 
sentido, somente a modalidade com atitude reflexiva atua na compreensão da experiência. Mas essa atitude reflexiva pode se desenvolver porque existem outros tipos de experiência, a préreflexiva ou pré-objetiva. O mundo se nos apresenta, antes de se mostrar como objeto de conhecimento, como uma esfera de ação prática que se dá através de uma inserção na situação.

"Os fins da ação não são formulações abstratas que dominamos intelectualmente para depois por em prática; antes, se nos aparecem como parte integrante da própria situação $e$, assim sendo, não se destacam enquanto planos refletidos. Apenas quando nos vemos ante à dificuldade de sustentar esta imersão prática (pré-reflexiva) no mundo é que ingressamos em uma atitude reflexiva" (Alves, Rabelo, Souza, 1999: 12).

Mas essa inserção no mundo, essa vivência pré-reflexiva não significa buscar um base pré-cultural (ou pré-social) da experiência, mas, ao contrário, perceber os modos como os sujeitos trazem consigo o social e o cultural. Segundo Heidegger (1997) existe a idéia de uma cumplicidade ontológica entre ser e mundo que o filósofo chama de dasein ou presença. De Martino (1958) supera este conceito de presença colocando-a na história, o que significa "fornecer um horizonte ao sofrimento, objetivando numa forma particular de coerência cultural...". Chamada historicamente a "fazer no mundo", a presença é uma dinâmica que deve transformar as situações em sentido, em valor.

Retomando Heidegger (1988), a compreensão antes de ser uma operação intelectual é uma realização prática, apóia-se em um senso de cumplicidade com o mundo que antecede qualquer elaboração reflexiva sobre objetos e que nos orienta, possibilitando a ação. Para esse pensador, (1976), a compreensão está sempre vinculada a um tom afetivo, ao "mundo da vida", ou como diz o filósofo, está em sintonia com uma disposição. Em outras palavras, a compreensão está estritamente ligada à situação emotiva, ou seja, à "emocionalidade", à afetividade, e o especifico daquilo que tradicionalmente é chamado "sujeito" ou "conhecimento" não é o elemento "racional", mas aquele emocional. Diz Battistrada:

"O conhecer, contra a inteira tradição gnosiológica, não é mais a cartesiana relação racional entre sujeito e objeto, completamente dividido, mas "um jeito de ser do ser-nomundo como ser-no-mundo" (Battistrada, 1999: 53).

Ao mesmo tempo, a "emocionalidade" reveste-se de um papel primário como "modalidade existencial do ser".

"Mas o conhecer - sublinha Heidegger - não instaura uma troca entre o sujeito e o mundo nem surge desde uma ação do mundo sobre o sujeito. O conhecer é um modo do ser fundamentado no ser-no-mundo" (1976: 87).

Mais tarde, nos diálogos com M. Boss, Heidegger voltará a esses assuntos, afirmando que "o ser numa tonalidade afetiva" não é algo existente por si, mas pertence ao "ser-no-mundo". O mundo que se abre na compreensão não é, então, um objeto que contemplamos de fora, mas um mundo em que estamos envolvidos e que já nos afeta de alguma maneira. A experiência embasase em um passado de envolvimento com os outros e as coisas, fazendo com que a situação emergente seja percebida através das disposições. Na disposição estamos entregues a um estado de ânimo, ainda que não percebamos isso. 
Similarmente, nos encontramos envolvidos em um mundo, em uma história, na qual só algumas possibilidades foram acontecendo. Podemos dar um outro rumo à nossa vida só refletindo apenas sobre a nossa trajetória. Para Heidegger (1976), existe uma ligação entre a disposição e o "vigor de ter sido" que nos remete ao nosso enraizamento originário, a uma situação na qual já nos encontrávamos, e que mostra o terreno a partir do qual nos lançamos em direção às possibilidades. Além disto, a disposição nos remete aos contextos de ação/interação os quais são articulados já tendo uma certa tonalidade afetiva (e à qual é preciso responder). Dessa maneira, toda disposição também revela possibilidades de agir com outros, a partir da experiência de uma certa história pessoal.

A experiência então não está fechada em si mesma; sua estrutura é, antes, circular, isto é, seu movimento é a repetição de uma certa configuração já dada na cultura. Mas tal movimento circular não é mera repetição (Heidegger, 1988; Gadamer, 1997; Ricoeur, 1994), e sim uma reelaboração do sentido segundo uma certa direção que prevê uma conservação e uma criação que se dá na prática sem uma reflexão previa.

Conforme sublinha Gadamer (1997), assim como a experiência retoma uma configuração prévia de sentido, ela envolve sempre uma descoberta do sentido em sua aplicação e desenvolve a sua historicidade nesse movimento entre retomada e descoberta. Essa dinâmica mostra a forma como nela estão implicados passado e futuro. A relação entre essas fases do tempo não é linear.

Merlau-Ponty (1968a) sustenta que passado e futuro ecoam um no outro, porém não em um cadeia causal que explica a experiência. O passado é constantemente objeto de elaboração indefinida a partir de um horizonte de expectativas, apesar de poder parecer, por um lado, que a experiência seja sempre pré-moldada em padrões culturais já fundamentados, sendo determinada por seu passado. Por outro lado, pode-se ter a impressão de que o passado não é mais que a preparação para a plena realização de um sentido que antes se dava por incerto e vago.

"Mas se a experiência (...) não é nem criação incondicional, nem reprodução de padrões já instituídos, se nela passado e futuro "ecoam um no outro", é porque está fundamentada no corpo e não em uma consciência ou mente soberana" (Rabelo, de Souza, 2000).

Desse modo, do ponto de vista de uma filosofia da encarnação (embodiment), o passado permanece no corpo enquanto conjunto sedimentado de minhas abordagens no mundo; permanece também a dinâmica de reaquisição pela qual são atualizadas as possibilidades vividas em direção ao porvir (Merlau-Ponty, 1968b). Assim podemos dizer que a disposição constitui um senso encarnado de minha posição, em um dado contexto, que retoma um passado envolvido com o mundo e com os outros.

Nesse ponto é importante levar em consideração o papel do corpo na experiência e a questão da inter-subjetividade. O corpo está diretamente associado à idéia de experiência enquanto modo de estar no mundo. É um corpo em situação, segundo uma perspectiva fenomenológica. Todas as atividades humanas são formas de uma práxis corpórea e expressão das dinâmicas sociais. O corpo é a dimensão do nosso próprio ser. É ele que nos fornece a perspectiva pela qual nos colocamos no espaço e manipulamos os objetos e esses dois elementos adquirem um sentido, um valor para nós. A subjetividade não é uma consciência que avalia o mundo de longe, mas é sempre uma consciência-corpo ou corpo-consciência. 
O corpo é o locus em que se inscreve e são manifestadas as várias dimensões da vida. Tais dimensões vão se integrando em um esquema e forma corporais que expressam uma modalidade particular de ser no mundo. Assim como o conceito de compreensão deve ser reformulado na experiência, Merlau-Ponty sugere que é o corpo que compreende, através de um movimento exploratório que antecede a qualquer racionalização pela qual nos conformamos a uma situação e respondemos à sua demanda. Nesse movimento de imersão no mundo e exploração ativa dos contextos de convivência e ocupação reside o "poder que temos de dilatar nosso ser-no-mundo ou mudar de existência anexando a nós novos instrumentos" (ibid: 1994: 199). Para tanto, é importante termos a noção de habitus desenvolvida por Merlau-Ponty. Para ele o habitus é uma praktognasia $^{17}$ ou seja um modo de conhecimento que está no corpo. Tal conhecimento corporal não é uma forma intelectual de compreender o mundo, pois ela gera representações.

Bourdieu, retomando as questões de Merlau-Ponty, elabora a noção de habitus como "um esquema prático de percepção e de apreciação que existe em um nível infra-linguístico e que são fundamentalmente disposições corporificadas" (1977; 1996). Para Bourdieu, a sociedade imbui o corpo dos princípios fundamentais da cultura através de meios insignificantes, como os trajes, os comportamentos verbais e corporais etc. Mas esses princípios não são incorporados conscientemente, não são explícitos.

"Nada parece ser menos inefável, menos incomunicável, menos inimitável, e, por isso, mais precioso do que os valores transmitidos ao corpo, feitos corpo pela transubstanciação adquirida pela persuasão escondida de uma pedagogia implícita, capaz de insuflar toda uma cosmologia, uma ética, uma metafísica, uma filosofia política, através de mandamentos insignificantes como 'fique em pé' ou 'não pegue a faca com a mão esquerda' " (Bourdieu, 1987: 94).

A religião constrói o habitus na dinâmica corporal e na ocupação do espaço com posturas repetidas várias vezes e com o uso do tempo não linear. Então o habitus é um corpo socializado e estruturado que incorpora as estruturas do mundo e que comporta tanto a percepção quanto a ação.

Para Merlau-Ponty (1994), o habitus expressa uma orientação do corpo para nossos projetos, permitindo uma renovação (ou um remanejamento) do nosso esquema corporal que é itinerato ao longo do projeto.

Desse modo, a experiência e seu caráter encarnado oferecem pontos importantes à análise da sociologia, como, por exemplo, os fenômenos ligados às religiões de possessão transformados numa realidade socialmente reconhecida -; como também a experiência do corpo, que nos permite conhecer importantes dimensões do sofrimento e da dor e como elas são transformadas na religião; transformação que se dá num corpo (forte, vivido em condição para nossa relação com o mundo).

Neste sentido Merlau-Ponty, desenvolvendo a noção de "corpo próprio", argumenta ser ele uma estrutura original, não pertencente à ordem da "pura coisa" nem à ordem da "pura idéia", dando à experiência corporal a importância devida. O corpo é lugar que integra o "em-si" e o

\footnotetext{
${ }^{17}$ A palavra praktognasia vem do grego e significa conhecer por meio do agir.
} 
"para-si", onde o "verbo" se faz "carne" e a carne se faz "verbo". Seguindo essa concepção, o corpo não é reduzido a um puro mecanismo fisiológico, mas é o veículo das intenções individuais; modo singular de ser no mundo. Esse corpo é enraizado no espaço, um espaço que habita, que conhece e que é o seu ponto de referência, em que ele desenvolve uma experiência vivida, dinâmica e significativa. Tal experiência vivida do corpo permite a sua abertura às coisas e ao outro - possibilitada pelos afetos, pela sensibilidade motora e perceptiva.

"Não trata-se então de um corpo-texto, espelho da cultura, que substitui o corpo vivido, fundamento da nossa inserção no mundo da cultura e ponto de partida para a reconstrução continua deste mundo" (Alves, Rabelo, Souza, 1999).

Csordas, retomando essas questões fenomenológicas, relata a falta de análise de rituais religiosos quanto ao significado existencial dos agentes: "uma análise do sujeito encarnado tomando uma posição existencial no mundo" (1994: 287).

A relação entre a fenomenologia do corpo com o aspecto cultural e social nos remete a um caráter intersubjetivo. A idéia de "ser-em-situação" não indica só a unidade corpo-mente, mas também o enraizamento fundamental do indivíduo no contexto social, porque é sempre "ser" com outros. Existe, então, uma sociabilidade originária da qual lentamente nosso ponto de vista se separa.

Este diálogo contínuo da nossa relação com o social, conforme Merlau-Ponty, é a base permanente da nossa experiência, pois, segundo ele, a família, a religião, o gênero "não são fatalidades que submetam o individuo do exterior, nem tampouco valores que ele ponha do interior. Elas são modos de coexistência que o solicitam" (1994: 487).

As colocações feita pelo filósofo francês são fundamentais para a compreensão da experiência das práticas religiosas, nas quais é preciso compreender primeiramente a experiência subjetiva em termos de enraizamento no mundo da cultura. E, em segundo lugar, os processos sociais pelos quais os indivíduos definem e legitimam suas experiências religiosa.

Portanto, se a experiência se sedimentada no corpo de modo individual, existe também um corpo social que é um corpo-superfície de escritura, no qual a sociedade escreve o texto das suas leis, carimbando-o. Cada cicatriz é um traço indelével, um sinal que faz do corpo uma memória da experiência pessoal e social. Por isso as sociedades não ocidentais, os grupos secretos e, claro, o candomblé iniciavam (e iniciam) com rituais que prevêem desenho e marcações no corpo com pinturas ou incisões, porque o corpo deve ter o sinal do grupo, alguma marca da passagem da juventude à maioridade ou da entrada em um grupo secreto.

Entendem-se assim o uso da estética no rito e nas religiões que foram amplamente relatadas por vários antropólogos e sociólogos, como Durkheim (1989), Radcliffe Brown (1964), Turner $(1967 ; 1969 ; 1974 ; 1975)$. Estudos mais recentes de Tambiah (1979) e Kapferer (1979a, 1979b, 1991) propõem o ritual como uma performance, na qual os meios artísticos criam vibrações carregadas de emoção, com um papel transformativo que manipula os símbolos, e na qual o corpo é "trabalhado" como veículo para reestabilizar os equilíbrio cósmicos individual e social. 
Sugerimos, então, que a estética do corpo atua como um papel fundamental porque está ligada à sabedoria, não aquela expressa por meio de palavras, mas pela experiência do próprio corpo, afirmada nos cortes rituais, nos trajes litúrgicos, nos objetos sagrados, nas danças e nas músicas. Por isso, a estética em geral está ligada a uma sabedoria armazenada e enraizada corporalmente ao longo de um processo que se passa e atua, portanto, no e com o corpo. Chegase assim às danças de transe, síntese final do processo religioso.

Não existe nas culturas tradicionais o conceito ocidental de "art pour l'art"; a arte contém sempre uma função: é concebida como parte da vida e como veículo e simbolização do sagrado.

Como frisa Luz (1995: 565), o conceito do belo ocidental não faz parte da tradição iorubá, contudo os nagôs definem o belo com a palavra odara, que significa ao mesmo tempo "bom, útil e belo". A beleza exterior, para os iorubá, deve corresponder a uma beleza interna (ou a um bom caráter). A beleza em si não é um grande valor se não estiver acompanhada por boas virtudes.

Entende-se assim o motivo pelo qual a representação da divindade se dá através da arte ritual. Essa tem por função expressar o invisível, sendo seu objetivo chamar e transmitir as forças imateriais. Cada objeto, cada cor, cada enfeite tem um significado simbólico que remete a outro mundo, o das forças espirituais. Na cerimônia, a dança, a música, os trajes litúrgicos, as cores, os símbolos seguem os padrões culturais aprendidos na iniciação e que são interligados por uma rede semântica, em que cada forma estética existe em função da outra, tendo como fim a comunicação entre os mortais e os orixás.

A dança e a música são meios particularmente propícios de representação de uma vida emocional feita de energia, conflito, tensão, espontaneidade, crescimento. Essa vida emocional é difícil de ser comunicada, porém, como sugere a filosofia, existem dois tipos de comunicação: uma fundamentada na lógica e na linguagem e outra destinada a exprimir e articular os sentimentos por meio de um simbolismo não verbal. Os gestos têm um significado, uma força restauradora e criativa que somente o uso das palavras não consegue transmitir. Por isso a comunicação nos rituais é transmitida através da dança, da música, do canto, veículos de conteúdos não verbais dotados de emocionalidade que origina uma eficácia específica. Como sugere Waterman (1962: 49-50), a dança comunica a mensagem afetiva de modo direto, isto é, através do movimento do corpo, que desperta uma resposta no público. A comunicação empática inconsciente da dança é considerada melhor em comparação a qualquer outra atividade social humana.

Langer relata que "a arte é a criação de formas que simbolizam sentimentos humanos" (1980: 40). As danças de transe, desse modo, revelam vários aspetos do candomblé: um lado visível, no qual a sociedade, através da arte, escreve sobre o corpo um texto para ser lido na comunidade e que assinala o status ao qual a fiel chegou, a visão de mundo e o ethos do grupo; e um segundo lado que é o lado invisível, o da transformação, o do mistério, o da síntese com o orixá. Nesse sentido, o corpo é um campo existencial de cultura no qual são enraizados novos padrões de comportamento durante a iniciação.

O corpo, no candomblé, não é considerado só o recipiente no interior do qual existe algo mais precioso, o espírito, a alma, tal como considerado na cultura ocidental. Ele é concebido e 
vivido como divino, sagrado, e em comunicação contínua com o mundo da natureza que o abrange. A sua forma, as suas cores, a sua postura o ligam à natureza. Entende-se assim porque o corpo e a dança no candomblé desempenham um papel fundamental no ritual. Seja nas danças de transe ou no cotidiano, o corpo adquire uma postura e um modo específico de se relacionar com os outros. As abiãs ${ }^{18}$, por exemplo, quando passam em frente a uma sacerdotisa mais velha devem dobrar-se e ter uma postura de humildade e recolhimento, assim como deve, na frente de um ogã, pedir sua bênção unindo as mãos uma sobre a outra em forma de concha. Há toda uma "educação postural" aprendida durante a fase de abiã, ao longo da iniciação e após a cerimônia de iniciação. É um aprendizado constante marcado pelo elo fundamental entre corpo e crença. Tratase, pois, de um conhecimento que se pode denominar como nitidamente "encarnado", isto é, presente na carne, no que ela exibe, no como, no quanto e no onde exibe.

Vários estudiosos já haviam demonstrado a relevância que as sociedades não ocidentais atribuem ao corpo, sendo este o único espaço apto a levar a marca do tempo, da passagem, do destino. Por isso as várias fases pelas quais uma abiã e uma filha-de-santo devem passar são sublinhadas através de uma estética corporal e plástica que explicita o estado espiritual da fiel. Eis porque o aspecto estético, cultivando até os particulares menos importantes, sinaliza a presença do sagrado no cotidiano e o cuidado para com aquele.

De acordo com Thompson (1974: 4), é por esse motivo que "a arte africana transmite a força vital, expressando-se dinamicamente e em movimento". Segundo o estudioso, a África introduz uma história da arte "dançante", visível nos movimentos do corpo, nas esculturas, nos desenhos simbolizados nos tecidos, arte que transmite aos seres humanos a energia vital por meio das cores, das linhas, dos tecidos. Mas a dança é a única que pode cumprir a transformação do objeto secreto misterioso, o espírito, em presença visual que se movimenta, que dança. Nela, o corpo adquire toda a sua importância e imponência, tornando-se o instrumento da divindade e se mostrando divino por si mesmo. Por indicar a vida, a possibilidade de agir, é o movimento que interessa no pensamento africano. Os orixás dançam, portanto, demonstram que o espírito é eterno e dinâmico como a vida. Nessa perspectiva, Lühning propõe o ponto de vista que toma a música de candomblé como uma música para dançar, em contraste com a música para ser ouvida.

Como expõe Sachs,

"A dança é a mãe das artes. Música e poesia determinam-se no tempo, as artes figurativas e a arquitetura no espaço; a dança vive igualmente no tempo e no espaço. Nela, criador e criação, obra e artista, são um todo único, movimento rítmico em uma sucessão espaço-temporal, senso plástico do espaço, viva representação de uma realidade visivel e fantástica" (Sachs, 1980:21).

A dança de transe permite a experiência do tempo e do espaço não mais como algo longe do fiel; o corpo parte deles e vice-versa, numa totalidade que se manifesta na fluidez do movimento. Essa característica espaço-temporal é o que caracteriza a dança, uma vez que atualiza sempre o movimento, renovando-o cada vez em um espaço-tempo "eterno" (Galimberti, 1987).

\footnotetext{
${ }^{18}$ As abiãs são fiéis que estão ao começo da hierarquia. Podem ter contas lavadas ou ter já o santo assentado.
} 
No ritual, as danças dos orixás evocam e recriam episódios míticos. Como já observou Bastide,

"As danças constituem a evocação de certos episódios da história dos deuses. São fragmentos de mitos, e o mito deve ser representado ao mesmo tempo que falado para adquirir todo o poder evocador" (Bastide,1978: 22).

No entanto, outros estudiosos da religião afro-brasileira, como Rodrigues (1935), Verger (1981) e Lody (1995), relatam a centralidade das danças religiosas, às quais atribuem o caráter de narrativa. Cossard-Binon, observando a importância da dança no universo afro-baiano, afirma que:

"A dança reproduz em movimentos e gestos, com o apoio da indumentária, a história e os feitos dos seres sobrenaturais, ou orixás, que são cultuados pela comunidade" (CossardBinon (1981: 127).

Apesar das várias referências acerca da importância do corpo e da dança no candomblé, poucos foram os estudos que se dedicaram a compreendê-los em profundidade, decifrando o seu riquíssimo simbolismo, assim como todo o processo de crescimento que está por trás. Cito os trabalhos de Barros e Teixeira (1989), que se ocuparam da simbologia do corpo, e de Leal (1995), que se volta mais para a questão do corpo e do seu significado. Em relação à dança, pode-se mencionar os estudos de Oliveira Cunha, que tratou da gestualidade no candomblé (1986), da dançarina Nóbrega, que pesquisou a dança afro-brasileira como sincretismo dos movimentos (1993), a tese de doutorado de Martins sobre a dança de Iemanjá (1995), e a minha dissertação sobre o simbolismo da dança de Oiá-Iansã (Barbára, 1995).

Além destes estudos pioneiros, não há literatura que aprofunde a ligação entre a experiência corporal, a estética e as relações sociais com os simbolismos dos orixás. Poucos são, enfim, os trabalhos sobre a arte no rito. Os estudos sobre as artes rituais, como observa Omari (1990), são limitados em comparação com os estudos sobre outros temas da religião do candomblé.

Concluo com as palavras de Levi-Strauss quando, em 1947, escreveu:

"Um estudo sobre as técnicas corporais traria informações de uma riqueza insuspeitável sobre migrações, contatos culturais ou empréstimos que se situam em um passado remoto e sobre os quais os gestos, em sua aparência insignificante, transmitidos de geração em geração, protegidos por sua própria insignificância, freqüentemente testemunham muito mais do que jazidas arqueológicas ou momentos figurado (...) "...Esses estudos forneceriam aos historiadores das culturas conhecimentos tão preciosos quanto a préhistória ou a filologia" (Levi-Strauss, 1974: 5). 


\section{Capítulo 2:}

\section{MÃe ÁFriCA, MULHERES NEGRAS: MÃES E SACERDOTISAS}

\subsection{Questões preliminares sobre o papel feminino}

O lugar que as mulheres ocupam hoje no candomblé é provavelmente o resultado de um processo que se originou ao longo da escravidão e da construção de papéis sociais e sagrados que tinham uma origem na cultura africana. Conforme Woortman (1987: 238) existira um continuum entre a escravidão e a família matrifocal na Bahia, pois naquele sistema escravista havia fatores que minimizavam as possibilidades da formação de famílias monogâmicas estáveis entre os escravos. $\mathrm{O}$ autor também parece sugerir que as condições da escravidão atuavam contra as possibilidades de desempenho do papel de "pater" dominante pelo homem escravo. O pai escravo era, de fato e de iure, irresponsável e desprovido de qualquer autoridade reconhecida ${ }^{19}$.

Além da autonomia conquistada com a lei do Ventre Livre de 1870, as mães obtiveram a legitimação completa dos seus filhos. Mas as mulheres acostumaram-se a ter relações afetivas temporárias e a não pensar em manter relação mais duradoura, pensamento ainda hoje relatado por várias mulheres (Bernardo, 1986). Desse modo, reproduziu-se entre os afro-brasileiros um tipo de poligamia disfarçada e não institucionalizada ${ }^{20}$. Nesse sentido, poderíamos situar a

\footnotetext{
${ }^{19}$ Por várias razões, mas principalmente pelo fato de que, até 1869 , as famílias podiam ser vendidas separadamente, restando a mãe como única referência (Melheiros, 1944).

${ }^{20}$ Segundo Verger (1992), as mulheres escravas conseguiram se libertar mais rapidamente do que os homens. Enquanto elas tinham já, ao longo da escravidão, uma maior possibilidade de movimento que as deixou livre de trabalhar, os homens, ao contrário, foram mantidos mais submissos, posto que mais perigosos em situação de rebelião e indispensáveis para a economia agrícola e trabalhos pesados.
} 
matrifocalidade religiosa como um continuum sócio-cultural observável amplamente nos cultos afro-brasileiros, considerada a homologia existente entre a família e o grupo de culto (Woortmann, 1987: 257). De um lado, este último incorporou certos princípios do sistema de parentesco iorubá tradicional; por outro lado, desenvolveu um princípio de matrifocalidade e dominância feminina, atestado por vários estudiosos, como, Landes (1967), Carneiro (1948) e Costa Lima (1977). No candomblé, o grupo se estrutura através de uma linguagem de parentesco, por isso Costa Lima o estuda como uma família-de-santo $(1977$; 1982).

Verger (1985) relata que a grande autonomia das mulheres da Bahia era uma influência da sociedade iorubá. Nesta etnia, o homem é polígamo e a descendência é patrilinear. As mulheres não podiam ter relações sexuais ao longo da gravidez e da amamentação, mas, por outro lado, aproveitavam-se de uma maior liberdade de movimento, enquanto que o homem podia se relacionar com uma outra esposa. Por serem, em geral, boas comerciantes, elas acabavam viajando e tendo, por si mesmas, seus ganhos. Também Bastide (1977: 79) fala dessa independência das mulheres na Nigéria; elas podiam andar livremente e comerciar nos mercados locais e outros de cidades distantes e, em pouco tempo, tornavam-se mais ricas do que os próprios maridos, que não se sentiam desvalorizados, mas orgulhosos de suas esposas.

Tal autonomia econômica apóia-se numa longa tradição na África Ocidental e não está em contradição com outros aspectos do papel da mulher e sua situação no interior da estrutura da sociedade a qual pertence (Mintz, 1977).

No Brasil, as escravas e as africanas emancipadas se utilizaram da possibilidade de formar confrarias católicas, que eram divididas segundo as diferentes etnias, e que vieram a possibilitar a reorganização dos antigos cultos africanos ${ }^{21}$ e a sobrevivência da memória dos ancestrais.

Como relata Verger,

"A instituição de confrarias religiosas, sob a égide da Igreja católica, separava as etnias africanas. Os pretos de Angola formavam a Venerável Ordem terceira do Rosário de nossa Senhora das Portas do Carmo, fundada na Igreja de Nossa Senhora do Rosário do Pelourinho. Os daomeanos (jejes) reuniam-se sob a devoção de Nosso Senhor Bom Jesus das Necessidades e redenção dos Homens pretos, na Capela do Corpo Santo, na Cidade Baixa. Os nagôs, cuja maioria pertencia à nação queto, formavam duas irmandades: uma de mulheres, a de Nossa Senhora da Boa Morte; outra reservada aos homens, a de Nosso Senhor dos Martírios" (Verger, 1981: 28).

Essa formação deu aos escravos a possibilidade de se reagruparem e praticarem juntos novamente o culto de seus deuses africanos, em locais situados fora das igrejas. Conta a tradição que, por volta de 1830, algumas antigas escravas libertas, originárias da cidade de Ketu e pertencente à Irmandade de Nossa Senhora da Boa Morte da Igreja da Barroquinha, criaram um terreiro de candomblé que veio a ser chamado Iá Omi Axé Airá Intilé, localizado inicialmente numa casa na ladeira do Berquó, próximo à igreja da Barroquinha.

${ }^{21}$ Como a irmandade da Boa Morte, que reunia as mulheres nagôs na igreja da Barroquinha, bairro próximo do Pelourinho (Verger, 1992), enquanto os bantos do Congo e de Angola se reuniam na Igreja de Nossa Senhora do Rosário, e os dahomeanos na de Nosso Senhor das Necessidades. Nestas dois últimas só os homens podiam fazer parte. 
Há diferentes versões sobre esse assunto (Azevedo, 1993; Costa Lima, 1977, do Nascimento, 1998; Carneiro, 1977; Verger, 1981), mas quase todas relatam a existência de três sacerdotisas (ou uma só, conforme outra versão), que eram portadoras dos seguintes títulos honoríficos africanos: Ialussô Danadana ${ }^{22}$, Ianassô Acalá ou Ianassô $\hat{o}^{23}$ Ocá, auxiliadas por um certo Babá Assicá, até hoje saudado na cerimônia do padê $\hat{e}^{24}$. Conforme Costa Lima (1977: 24), Ianassô é um titulo altamente honorífico da corte do Alafin de Oió, e corresponde a funções religiosas específicas e da maior significação no cultura iorubá. Essa sacerdotisa é a encarregada do culto de Xangô, uma das principais divindades do panteão iorubá e o orixá principal do rei de Oió, cidade que foi a sede do último império em terras iorubás. É a Ianassô que cuida do santuário privado do Alafin e realiza todas as cerimônias propiciatórias do culto do orixá do rei.

Ialussô Danadana, segundo consta, voltou à África e lá morreu. Essa sacerdotisa tinha viajado com Marcelina da Silva, a qual não se sabe se era filia legítima ou espiritual da primeira ou uma sua prima (Costa Lima, 1977). Deram-lhe o nome de Obatossí. Com Marcelina-Obatossi, viajou também sua filha Madalena que, por sua vez, teve duas crianças na África e voltou ao Brasil grávida de uma terceira, Claudiana, que veio a ser a mãe de uma outra ilustre sacerdotisa da Bahia, Mãe Senhora, Oxum Muiuá. De volta com Ianassô e Obatossi chegou também um africano chamado Bangboxê, que no Brasil recebeu o nome de Rodolfo Martins de Andrade, saudado no padê como Essa Obitikô.

O terreiro que formaram mudou-se várias vezes até se estabelecer na avenida Vasco da Gama, com o nome de Ilê Ianassô ou, como mais familiarmente é chamado, Casa Branca do Engenho Velho. Segundo Johnson,

"Ela tinha direito ao terceiro lugar na hierarquia das oito sacerdotisas responsáveis pelo culto no palácio do rei e figurava entre os quatros dignitários que deviam acompanhar o Alafin de Oió na morte, suicidando-se quando ele passava desta vida para a outra" (Johnson,1921: 63).

Conforme Verger (1992: 114), é provável que uma escrava (embora emancipada) que fundou uma organização hierárquica e que tinha uma posição tão elevada como a de responsável pelos cultos do orixá no palácio do rei de Oió tenha contribuído para impor ao candomblé a influência das mulheres.

Dentre as diferentes tradições orais existentes na Bahia, a tradição do terreiro do Gantois, fundado em 1847, conta que a primeira mãe-de-santo teria sido Iá Acalá (distinta de Ianassô) e a segunda, Ianassô Ocá (e não Acalá). É difícil reconstruir os fatos históricos, sobretudo porque na memória dos velhos terreiros tudo é baseado na narrativa oral. Além do mais, tudo que dizia respeito aos orixás era escondido, revestido do maior sigilo, pois no início do século XIX a religião católica era a única religião autorizada.

\footnotetext{
${ }^{22}$ Segundo Costa Lima (1977: 24) a primeira das três sacerdotisas poderia ter nome também de Adetá.

${ }^{23}$ Como explica Costa Lima (1977: 24), Ianassô não é um nome próprio iorubá, mas antes um título, um oiê que se atribui às pessoas para determinar ou modificar o seu status na estratificação social do grupo ao qual pertencem.

${ }^{24}$ É um dos principais rituais no candomblé. Veja-se Elbein dos Santos (1977).
} 
Conforme Verger, com a morte de Marcelina-Obatossi, Maria Julia Figueiredo foi escolhida a nova mãe-de-santo. Também era chamada Omoniquê, Ialodê, e Erelu, na sociedade secreta das máscaras Gueledés. A sucessão provocou a saída de uma sacerdotisas insatisfeita com a escolha, que depois fundou o Iá Omi Axé Iamassê, no alto do Gantois, no bairro da Federação. Outra dissidência, ocorrida na sucessão seguinte, deu origem ao Axé Opô Afonjá, pelas mãos de Aninha Obabii e de Joaquim Vieira da Silva ${ }^{25}$, Obasaniá, saudado no padê como Essa Oburô. Em 1910, depois de temporariamente instalado no bairro do Camarão, esse terreiro mudou-se para o bairro do Rio Vermelho e, devido ao esforço e ao prestígio da mãe-de-santo, tornou-se rapidamente conhecido e chegou a ter uma grande popularidade.

Outro tipo de reconstrução ocorrida nos cultos afro-brasileiros foi de grande importância. Os escravos de descendência iorubana se reuniram também em sociedades secretas de máscaras, sobretudo a sociedade Guelede ${ }^{26}$, que cultua a ancestralidade feminina, e a dos Egunguns ${ }^{27}$, de culto aos antepassados masculinos. A sociedade Gueledé não foi adiante, mas a dos Egunguns até hoje se preserva na ilha de Itaparica (Braga, 1992), em Salvador, no Rio de Janeiro e em São Paulo.

As celebrações Gueledés são muito importantes na sociedade iorubá por duas razões: a primeira refere-se ao sentido da preservação da humanidade, dependente que é do papel da mulher como mãe; já a segunda liga-se à maternidade como um poder especial que conecta as mulheres à feitiçaria, que é considerada própria do poder feminino, poder que pode ser usado para o bem e para o mal. Os rito das máscaras destina-se ao apaziguamento das "antigas mães" 28 e à conciliação das diferentes posições de interesse em prol da paz e da harmonia social. A sociedade enfatiza a importância de se estar sempre consciente do perigo que as situações antisociais desenvolvem contra o equilíbrio da sociedade ${ }^{29}$. Neste sentido, contribui para o controle social, combatendo os desvios e ações indesejadas, sobretudo aquelas condizentes com a prática da magia negra.

Os iorubás (Drewal, 1992: 177) acreditam que a concentração de força vital nas mulheres, seu axé, seu poder de fazer as coisas acontecerem, gera um extraordinário potencial que pode ser canalizado de duas maneiras, uma positiva e a outra negativa. Uma série de expressões expressam essa ambígua dualidade, o bem e o mal, e o grande poder de transformação das mulheres como oloju meji, que significa com duas caras, ou abara meji, com dois corpos. Alguns

\footnotetext{
25 Tio Joaquim era tio carnal de Mãe Cantu, Cantulina Garcia Pacheco, que é a mãe-de-santo titular do Axé Opô Afonjá no Rio de Janeiro, mas que hoje, centenária, mora no Axé da Bahia.

${ }^{26}$ Ainda há no museu do Axé Opô Afonjá duas dessas máscaras e, de acordo com algumas informações por mim recolhidas, parece que até a época de mãe Senhora existiam alguns rituais ligados à elas. Gueledé (Lawal, 1996) é uma sociedade feminina que tem como função festejar o poder feminino contido na maternidade numa cultura patrilinear, a dos iorubás, na qual os homens dominam a instituição do poder profano (Drewal, 1992).

${ }^{27}$ A sociedade dos egunguns tem a função de dramatizar a crença iorubá na vida depois da morte. Suas máscaras representam os espíritos dos ancestrais que voltam à Terra para purificá-la e para visitar seus descendentes, assim como ajudar e abençoar os doentes e resolver as disputas sociais (Lawal, 1999).

${ }^{28}$ Veja-se neste sentido Verger (1992: 8-91).

${ }^{29}$ Pensamento relatado também por duas informantes nigerianas.
} 
versos de Ifá (1992: 178) falam das três categorias de poder das mulheres, chamadas eufemisticamente eleyé, "donas do pássaro", e mostram seu poder de transformação ${ }^{30}$. O poder ${ }^{31}$ pode ser eleyé branco ${ }^{32}$, com um sentido benéfico, o eleyé vermelho, que traz sofrimento, e o eleyé negro que traz a morte. Por meio desses poderes, as mulheres acreditam ter a possibilidade de se transformar em animais e, assim, ter acesso a coisas secretas.

A sociedade dos Egunguns, por sua vez, enfatiza a dominância masculina. Entre outras atribuições de justiça, essa sociedade pune as mulheres suspeitas de serem feiticeiras.

Entendemos, então, que os conceitos iorubá de poder masculino e feminino originam-se da divisão dos valores culturais resultantes da interpretação dos fatores biológicos, entendidos como opostos binários (Drewal, 1992: 179). Nesse sentido Drewal mostra, através de várias entrevistas com iorubás, a existência, mais que uma predominância masculina ou feminina, de uma simetria, uma complementaridade de opostos entre os dois sexos. Desse modo, a questão de gênero é uma construção que separa os sexos em duas categorias exclusivas para sublinhar as diferenças biológicas, tendo como efeito direcionar o comportamento humano (que não é biologicamente determinado). Ao se construir o gênero, sublinham-se as diferenças e se atribuem claramente os papéis a serem desempenhados pelas mulheres e pelos homens na sociedade. Para as mulheres os valores são a paciência (suuru), a gentileza (ero), a serenidade (itutu) e a perseverança (iroju).

Drewal continua apontando o fato de a continuidade por meio da progênie ser a base da ontologia e do ser iorubá. A procriação e a maternidade são os seus valores primários e é ao redor delas que são construídos novos valores e o ethos dessa civilização. Na ontologia iorubá existe uma ênfase à continuação da vida, à corrente que liga o ser humano ao seu antepassado e aos seus filhos, existe um fluxo físico de energia da vida que não pode ser quebrado. É a vida que continua, neste sentido Beier explica bem este conceito:

"Um orixá não é cultuado pela sua virtude, mas pela sua vitalidade. Aquilo que atrai os homens em Xangô é a intensidade da vida. Cultuando-o, os homens participam da sua força vital e recebem uma ajuda para chegar a uma vida mais alta. Ao mesmo tempo, a adoração rejuvenesce o poder do orixá. Pode-se também dizer que a comunidade dos fiéis o ajuda a estabelecer e a acrescentar seus poderes: a expressão iorubá para adorar é 'se orisa', que quer dizer 'criar' o deus."

Note-se que nessa frase "criar" tem o sentido de cuidar, zelar ${ }^{33}$, tomar conta, outra vez um dos papéis universais das mulheres. A esse respeito Abiodun (1989: 1-18) mostra a importância do feminino, enfatizando o lugar da mulher como mãe e nutridora.

\footnotetext{
${ }^{30}$ Sobre este assunto veja-se o artigo de Verger (1994).

${ }^{31}$ Talvez, ainda hoje exista no Brasil uma lembrança (e quem sabe uma continuação) desses cultos na Irmandade da Boa Morte, em Cachoeira, no Recôncavo baiano. As mulheres da Boa Morte saem por ocasião da Festa de Nossa Senhora com um traje especial que leva três cores: o branco, o vermelho e o preto. Veja-se Elbein dos Santos (1977: 41) e do Nascimento (1999).

${ }^{32}$ Sobre o simbolismo das cores veja-se Elbein dos Santos, 1977.

${ }^{33}$ Zelar é um verbo muito usado pelos velhos de candomblé, significa cuidar criar o orixá, cuidar de seu culto.
} 
Então, pode ser que na instalação dos cultos afro-brasileiros na Bahia tenha ocorrido uma complementaridade e divisão de competências religiosas. Como faziam os antigos em relação às sociedades secretas, distribuíram-se as tarefas: as mulheres, originalmente ligadas ao culto das máscaras Gueledés, deveriam ocupar-se dos orixás — orixá é coisa de mulheres - enquanto aos homens ocupar-se do culto dos Eguns, os antepassados.

Como relata Landes (1967: 32), Martiniano do Bonfim, o respeitado velho mestre do candomblé baiano que durante muito tempo orientou as mães-de-santo, observou que "sempre houve lugar para homens no templo como ogãs, orientadores e pessoas de fé, mas nunca como médiuns para serem possuídos pelos espiritos dos deuses". Alguns velhos terreiros, pouquíssimos, é verdade, ainda seguem essa orientação.

Deve ser esclarecido que no candomblé cada pessoa tem uma função e um papel sacerdotal a ser desempenhado, dependendo do orixá ao qual pertence, do posto já alcançado na hierarquia, ou de ser ou não aiabá ${ }^{34}$ (neste caso, filho ou filha de orixá feminino). Convém lembra que há sempre uma polaridade masculino-feminino. Em terreiros mais antigos da nação queto, a sacerdotisa suprema é uma mulher, assim como são mulheres as lideranças do terreiro, mas os homens, os axoguns, é que são os responsáveis exclusivos pelo sacrifício de animais de quatro patas. Do mesmo modo, nos cultos dos Eguns os sacerdotes são homens, os ojés, contudo, quem cozinha para os ancestrais são as mulheres.

Tal polaridade de poder feminino e masculino também é relatada na pesquisa da Birman (1995: 70) ${ }^{35}$, que retoma as questões propostas por Landes. Ambas tratam do gênero, e Birman procura entender o que seria a "normalidade" masculina e feminina no culto (Birman, 1995: 132). Depois de longa análise sobre os papéis sagrados e a hierarquia, propõe a existência de dois pólos: o feminino e o masculino. Um representa o pólo exterior às relações consangüíneas que une pais e filhos pela famosa filiação espiritual do candomblé ${ }^{36}$. No pólo masculino situam-se os ogãs, com seus papéis relacionados ao mundo externo como estabelecer relações entre o terreiro e o mundo exterior, sacrificar os animais, coletar as folhas etc. Contudo, segundo a autora, é no interior do pólo feminino que todos se aproximam e se relacionam como consangüíneos, partilhando da mesma casa e de vários atributos em comum.

Mas isto não significa que o gênero preenchido pelo sexo feminino seja um só, correspondente na sua figuração ao sexo biológico. Minha proposta é que o ser humano participante do candomblé se situa nalgum ponto de um continuum que vai do pólo masculino ao feminino, de acordo com as afinidades e escolhas que lhe são peculiares, sofrendo assim uma espécie de reformulação no âmbito nível do gênero. O gênero sem dúvida está ligado a papéis. A iniciação ${ }^{37}$ no candomblé corresponde sempre a um renascimento e é ao redor desta passagem, do

\footnotetext{
${ }^{34}$ As aiabás são os orixás femininos: Oxum, Obá, Oiá, Iemanjá, Euá e Nanã. A designação também se aplica aos filhos e filhas desses orixás.

${ }^{35}$ Apesar de Birman ter pesquisado no Rio de Janeiro, suas conclusões podem valer para outras localidades.

${ }^{36}$ Filiação espiritual no modelo simbólico da filiação iorubá (Costa Lima, 1977; Drewal, 1977).

${ }^{37} \mathrm{O}$ processo iniciático se conclui com a obrigação de sete anos.
} 
renascimento a uma nova vida, que se dá a construção religiosa dos papéis e da pessoa, sempre definidos a partir dos rituais dos orixás.

\subsection{O terreiro Axé Opô Afonjá, o contexto da pesquisa,}

Mãe Aninha, uma das grandes figuras dos candomblés da Bahia, nasceu em 1869, filha de dois africanos: Anió (nascido na África, mas batizado no Brasil) e de Azambrió (pertencente à etnia grúnci).

Como relata Mãe Stella ${ }^{38}$,

"Ainda era Iyalaxé da Casa Branca Julia Figueiredo, quando Aninha Oba Biyi", completando sete anos de iniciada, teve ordem de ser mãe-de-santo. Teve como primeira filha-de-santo Paula de Ogum, na própria Casa Branca. Com a morte de Maria Júlia, assumiu Marcelina, dai surgindo divergências, culminando com o afastamento de um grupo liderado por Aninha, que foi para a Rua do Camarão, numa roça, no Rio Vermelho, onde funcionava o Terreiro de Pai Joaquim - Obassainá - Essa Oburo".

Desde aquele época, mãe Aninha mudara-se para a Rua Santa Cruz, no bairro do Nordeste, sempre em Salvador. Fazia iniciações, como a de Rosalina de Oxalá, em sua residência, apesar de existir o espaço da roça de candomblé.

Em 1903 mudou-se para a rua Corriachito, onde iniciou mais duas filhas-de-santo, Salu de Airá e Maria das Dores de Oxóssi. Em 1907 mudou-se para a Ladeira da Praça, onde Mãe Senhora, Oxum Muiuá, foi iniciada com outras cinco irmãs de barco, além de outras iaôs ${ }^{40}$ recolhidas dias depois. Naquele tempo Mãe Aninha morava na ladeira da Praça, número 77, no Pelourinho. Em 1912, na residência da Ladeira da Praça, Mãe Aninha iniciou, ainda menino, o professor Agenor Miranda Rocha ${ }^{41}$, que veio a ser mais tarde o oluô do terreiro do Afonjá e de outros candomblés por ocasião do falecimento da mãe-de-santo. Conta-se que, pouco antes disso, Aninha teve um sonho no qual Xangô a mandava comprar uma roça. E em 1910 ela adquiriu um terreno no alto de São Gonçalo do Retiro e lá fundou seu próprio terreiro, ao qual deu nome de Axé Opô Afonjá. Nele, onde cada orixá tem a sua casa. Uma das mais misteriosas construções do terreiro de Mãe Aninha é a casa de Iá, a casa de Iemanjá, em cujo interior jorra uma fonte na qual se cultua Iá, divindade grúnci ${ }^{42}$ que Aninha herdou de seus pais. Com a ajuda do babalaô

\footnotetext{
${ }^{38}$ A atual mãe-de-santo do terreiro.

${ }^{39}$ Obabii significa o rei nascido nesta Terra.

${ }^{40}$ Iaô significava originalmente esposa, esposa do orixá. Hoje é sinônimo de filha ou filho-de-santo, a mulher ou homem iniciado para ser possuído pelo orixá.

${ }^{41}$ Sobre a história do Professor Agenor, o único oluô da tradição queto e balogum da Casa Branca, há vários livros (Rebouças Filho, 1998; Sodré e Lima, 1996).

${ }^{42}$ Os grúncis são um povo do grupo lingüístico gur que alguns autores chamam de voltaico e eram conhecidos na Bahia antigamente como "nação galinha" (Rodrigues, 1932: 312).
} 
Martiniano Elizeu do Bonfim ${ }^{43}$, elo de ligação entre o Axé e a Nigéria, a ialorixá do Afonjá organizou o corpo dos doze obás de Xangô ${ }^{44}$, responsáveis pela condução civil dos destinos do terreiro, reconstituição simbólica da corte africana de Oió. Conta-se que Mãe Aninha teria instituído que a chefia do terreiro deveria passar sempre pela linha feminina ${ }^{45}$.

Essa ialorixá criou uma casa de candomblé que, além dos rituais da religião, teve a possibilidade de abrigar filhos-de-santo menos favorecidos e mesmo amigos em difíceis conjunturas.

"Mãe Aninha costumava dizer à sua irmã carnal Andreza que criara a Roça para Xangô e para os seus filhos-de-santo. Ela era passageira, o Axé, não" (Azevedo e Martins, 1988).

Desse modo, vários filhos e filhas-de-santo foram socorridas pela ialorixá, tanto devido a dificuldades financeiras, quanto por causa de perseguição política, como foi o caso de Édison Carneiro, o qual, tendo se refugiado na Casa de Oxum, ficou aos cuidados de Senhora, que era então a ossi-daga $\tilde{a}^{46}$ do terreiro.

Mãe Aninha foi várias vezes ao Rio de Janeiro, onde fundou o Axé Opô Afonjá que é irmão daquele da Bahia. Com determinação e inteligência, essa mulher conseguiu junto a Getúlio Vargas, por meio do Decreto 1202, o reconhecimento e a liberação do culto afro-brasileiro, que até aquele momento era tido como "coisa de negro ignorante, prática fetichista e vergonha da Bahia". Algumas das velhas sacerdotisas do Axé dizem que mãe Aninha era uma personalidade imponente e que o seu Xangô era um grande mágico.

"Filha, lembro ainda eu pequena na festa do Xangô dela, ele dançava, dançava e de repente começou a cuspir pedras, sim, sim, pela boca. O Xangô de mãe Aninha cuspiu pedras de raio pela boca, mas era criança ainda não entendia nada das coisas e ai perdi as pedras. Se tivesse tido um pouco mais de cabeça! E não só eu vi esta magia, mas várias pessoas correram para pegar as pedras". ${ }^{47}$

Em 1936 realizou-se em Salvador o Segundo Congresso Afro-Brasileiro e nele mãe Aninha apresentou um relatório sobre a culinária do candomblé e ofereceu no final uma grande recepção, com danças rituais, toques e guloseimas baianas. Ela mesma inventou o hino do Axé que canta-se em ocasião de algumas festas. No mesmo ano ela criou o Centro Cruz Santa do Axé Opô Afonjá, que é a sociedade civil responsável pelos assuntos profanos do terreiro.

Mãe Aninha faleceu em 1938. Dizem seus descendentes espirituais que teria levado consigo muitos conhecimentos religiosos que não teve tempo de transmitir aos filhos.

\footnotetext{
${ }^{43}$ Martiniano do Bonfim e Felisberto Sowzer foram os últimos babalaôs, e muito respeitados, sobretudo o primeiro.

${ }^{44}$ Sobre este assunto, veja-se o artigo de Costa Lima, Os obás de Xangô, em de Moura, 1981: 87.

${ }^{45}$ Muitos estudiosos relataram que a liderança nos terreiros de candomblé de nação queto é feminina, enquanto nos de tradição Congo, angola e caboclo pode ser também masculina. Dificilmente se comprovaria tal hipótese.

${ }^{46}$ Ossi-dagã é um cargo que recebem as sacerdotisas que se ocupam do padê no Axé Opô Afonjá.

${ }^{47}$ Fala de uma informante do Axé, mãe Almira de Oiá.
} 
"Dizem que pouco antes de falecer chamou as pessoas mais próximas e falou em iorubá, mas ninguém entendeu nada, pela fala e quem sabe, ela estava já fraca. Mas quando as pessoas pediram para ouvir outra vez aquilo que ela tinha dito, mãe Aninha respondeu: não sabem o que perderam". ${ }^{48}$

Mãe Aninha tinha feito construir um cruzeiro em frente ao lugar de culto aos ancestrais, onde foi celebrada uma missa católica. Naquela época existia o costume, que ainda hoje se preserva em muitos candomblés, de rezar missa nos terreiros, assim como os costume de levar os novos filhos-de-santo, logo depois da iniciação, à igreja do Bonfim e a outros templos católicos.

Após a morte de Mãe Aninha, Mãe Bada Olufandeí, que tinha o cargo de baró, assumiu temporariamente o axé. Mãe Bada morreu em 1941 e, conforme o jogo de búzios realizado pelo Professor Agenor Miranda Rocha, Mãe Senhora, Oxum Muiuá, foi escolhida como a nova mãede-santo. Mãe Senhora, famosíssima na Bahia, dedicou-se ao Axé Opô Afonjá por mais de trinta anos. Tinha uma especial dedicação para com Xangô e sempre, como diz mãe Stella: "o consultava para as mínimas coisas, pois era seu orientador e confidente. Apesar da sua dedicação ao Axé nunca faltava nas festas do terreiro de egunguns, o Ilé Agboulá ${ }^{49}$, onde ocupava o importante posto de Iá-egbé, a chefe da sociedade feminina".

Por meio de uma complicada filiação, Mãe Senhora era bisneta de Obatossi por laços de sangue e, por laços espirituais de iniciação, sua neta. Mãe Senhora faleceu em 1967 e foi sucedida por Mãezinha Iwintonã, Ondina Valério Pimentel. O jogo de búzios para definir a sucessão foi efetuado pelo professor Agenor. Em 1975 morreu mãe Ondina e, novamente com o jogo de búzios do Professor Agenor, foi escolhida, no dia 17 de junho de 1976, Mãe Stella Odé Kaiodê, Maria Stella de Azevedo Santos, a atual mãe-de-santo.

No terreiro do Axé Opô Afonjá, que pela sua extensão e organização pode ser tomado como um modelo exemplar, existem dois espaços com características e funções diferentes: um espaço urbano, com construções de uso público e privado, e um espaço de mata que compreende as árvores e uma fonte. A parte urbana é constituída da seguinte maneira:

a) diversas casas dos orixás, sendo que cada orixá tem sua própria casa, exceto as divindades jejes, Omulu, Nanã e Oxumarê, que ocupam uma única casa, e a casa de Iá, que abriga também algumas outras divindades grúncis;

b) a casa de Oxalá que, além do quarto deste orixá e o das aiabás, contém os quartos em que os iaôs são recolhidos, uma cozinha ritual (com uma ante-sala) e vários quartos para abrigar algumas sacerdotisas nos dias de rituais e em outras ocasiões;

c) o barracão, que é o salão das danças públicas, e que foi reformado há pouco tempo, depois do tombamento do Axé pelo Patrimônio Histórico em dezembro do 2000;

d) um conjunto de casas residenciais para os iniciados que fazem parte do Axé e suas famílias;

e) o Ilê Ibó Iku, a casa dos ancestrais, situado um pouco mais afastado e circundado por plantas e árvores, do qual ninguém pode se aproximar, a não ser os sacerdotes preparados para esses mistérios;

\footnotetext{
${ }^{48}$ Entrevista com a ebômi Eugenia de Oxalá.

${ }^{49}$ Este é o terreiro dos eguns situado na ilha de Itaparica.
} 
f) um museu do Axé, que Mãe Stella fez instituir em 13 de novembro de 1981.

Sobre a construção do museu disse Mãe Stella:

"Eu quero fazer o possivel para quando o africano, ou outra pessoa interessada em restabelecer a tradição ritual queto desejar informações aqui em casa, no nosso Axé, a encontre, uma vez que os cultos originários desta cidade ou nação foram cruelmente destruidos durante a guerra do Abomey em 1886, e nós aqui os preservamos. Oni Kowé50, nós precisamos fazer o museu".

Nasceu então o Ilê Ohun Lailai, a "Casa das Coisas Antigas". O museu é formado por três salas repletas de objetos rituais do candomblé, fotografias das comidas e das principais folhas sagradas. As cadeiras e objetos pessoas das antigas mães-de-santo ocupam lugar de destaque. Numa sala interna estão expostas as antigas estatuetas dos santos católicos que mãe Stella tinha feito tirar dos quartos dos orixá — depois do famoso manifesto do 1983 , contra o sincretismo ${ }^{51}$ —, e duas máscaras das Gueledés.

No terreiro foi construída a Escola Eugênia Ana dos Santos, com o papel de democratizar ações educacionais, oferecendo iguais oportunidades de ensino para todos os que desejam matricular-se no primeiro grau $\left(1^{\mathrm{a}}\right.$ à $4^{\mathrm{a}}$ série), mas preocupando-se com a preservação das tradições de origem africana. A escola é a realização de um dos sonho de mãe Aninha, exposto no estatuto da Sociedade Cruz Santa, conforme publicação no Diário Oficial de 4 de janeiro de 1969. Ela é freqüentada por cerca de 150 crianças da comunidade e do bairro do Retiro. Desde 1997 existe também um projeto de mobilização social, chamado Criança em Risco - Comunidade Afonjá, com várias oficinas.

Já o espaço da mata cobre quase dois terços do terreiro e é pleno de árvores, arbustos, ervas. Ali são feitos os rituais ligados à mata, freqüentada pelos sacerdotes de Ossaim e de duas outras divindades associadas à mata, Oxóssi e Ogum.

A comunidade do Axé abriga umas cem famílias que moram estavelmente no terreiro. Cerca de 300 pessoas freqüentam o terreiro durante as festas, sem contar as pessoas que procuram esporadicamente a casa para o jogo de búzios, rituais de limpeza e outros serviços mágico-religiosos.

\subsection{Mãe Stella de Oxóssi, Odé Kaiodê}

Mãe Stella, a atual mãe-de-santo do Axé Opô Afonjá, como as mães-de-santo precedentes caracteriza-se por grande capacidade e firmeza na liderança. Desde o começo, manteve renomada postura política em prol da legitimação do candomblé na sociedade brasileira. Visitou a África

\footnotetext{
${ }^{50}$ Oni Kowé é o nome da pessoa encarregada de organizar o museu.

${ }^{51}$ Em julho do 1983, por ocasião da II Conferência Mundial da Tradição dos Orixá e Cultura, Mãe Stella assinou com outras mães-de-santo um manifesto contra o sincretismo. Foi uma peça política de grande importância para o povo de candomblé (Consorte, 1999). Sobre o movimento contra o sincretismo no candomblé, veja-se Prandi (1999a).
} 
duas vezes, colocando-se como figura capaz de fazer a religação do candomblé com aquele continente, e mostrando-se interessada em dar continuidade à busca das origens africanas. Em 1983 assinou o manifesto contra o sincretismo católico, iniciando uma verdadeira luta pela africanização e desligamento do candomblé do catolicismo, visto como uma depauperação da "pureza" dos cultos afro-brasileiros (Consorte, 1999).

Fato novo neste mundo tão ligado à transmissão oral, Mãe Stella, em co-autoria com a ebômi Cleo Martins, publicou dois livros, E daí aconteceu o encanto (1988), que relata a história do Axé e fala de Mãe Aninha, e Meu tempo é agora (1993), que trata da vida e da postura religiosa dos filhos e filhas-de-santo no terreiro. Este livro foi escrito porque, como ela mesma diz, "o que não se registra, o vento leva....". Este último livro procura chamar a atenção de seus filhos e filhas para uma postura ética e religiosa, sublinhando que a gente tem que viver do melhor jeito possível para a época à qual pertencemos e que cada época tem uma riqueza em si e porta uma transformação. Há uma frase no começo do livro que esclarece muito bem os percursos de vida e de religião que um fiel é chamado a fazer : "Só descobrindo por nós mesmos é que entendemos e adotamos um ideal..."

Com essas palavras percebemos que a mensagem do candomblé é a de procurar um diálogo com o nosso orixá. Tal diálogo deve levar as pessoas a aprender a escutar as "vozes" que vem do orixá e do sagrado. Isso é muito difícil num mundo que propõe exatamente o oposto. As mensagem são múltiplas e contínuas. Parar e escutar é uma arte que se desenvolve aos poucos, no curso das obrigações rituais.

Nesses anos que passei como pesquisadora no Axé, Mãe Stella e as outras velhas sacerdotisas sempre insistiram em me ensinar a parar e escutar. Foi assim desde a primeira vez que consegui falar com ela sobre a minha pesquisa, fato muito raro porque está sempre ocupada em fazer algo. Era uma tarde, lá pelas 18 horas, quando entrei na casa de Xangô, pensando : "será que Mãe Stella vai se lembrar de mim?" Ela não tinha esquecido de nosso compromisso, me esperava em companhia de seu cachorro, um belo setter irlandês e, coisa estranha, ninguém mais estava por perto.

Como em muitas outras vezes, me senti pequena perante essa senhora e seus olhos que pareciam feitos d'água. As palavras, no meu português de italiana, saíam com dificuldade. Ela me sorriu e, sem quê nem porquê, me perguntou de que eu tinha medo. Não era medo, mas apesar de da minha pesquisa, sentia que estava invadindo um território que não era o meu.

- Minha filha, não tenha medo. Quem chega aqui, até para pesquisar, é chamado por Xangô; então não se preocupe - ela disse. E com seu jeito singelo, me falou dos orixás e colocou algumas questões que mais tarde me pareceram muito difíceis.

Essa é Mãe Stella: dona de um axé e de uma fé inabalável que lhe permitem aproximar se de pessoas diferentes e de vários lugares do mundo com simplicidade e espontaneidade. Parece que uma verdadeira corrente liga as mães-de-santo, pois uma continua o trabalho da outra, atualizando-o, mas mantendo a tradição e a comunidade ao redor de si e do axé do patrono do terreiro. 


\subsection{Uma quarta-feira no Axé Opô Afonjá}

"Uma aiabá nunca carrega esteira, eu vou carregar para você, iaiá!" Uma grande e bela mulher pegou a esteira das mãos de outra, pondo-a debaixo do braço. As duas estavam indo na direção da casa de Xangô; a mais velha, com grande elegância e com uma postura real, enquanto a outra, de estatura mais alta, a seguia com um ar tímido e de quem não estava entendendo o que acontecia. Foi uma das minhas primeiras estadias como pesquisadora no templo da negritude baiana, o Axé Opô Afonjá. Como que encantada, segui as duas que entravam na casa de Xangô. Era dia de amala $^{52}$, a comida sagrada do rei. A primeira quarta-feira do mês é um dia de grande animação no terreiro; todo mundo vem para as oferendas e para participar daquele ritual de comunhão, o amalá de Xangô. Por causa dele, todas estas pessoas se encontram no Axé à procura de força e reparo na vida.

Os preparativos do ritual começam de manhã cedo, lá pelas seis horas, porém, quando há muito quiabo para ser cortado, as sacerdotisas mais velhas, que usualmente moram no terreiro, já o preparam desde a noite precedente. A rotina diária começa de manhã cedo: enquanto as filha de Xangô tomam conta do altar do orixá, mudando a água das quartinha e trocando a roupa do peji ${ }^{53}$, enfeitando-o com flores brancas e vermelhas e botando frutas num cesto, as outras cortam quiabo e cozinham. Na casa de Xangô há uma cozinha onde é preparada sua comida. Aí, sentada sobre um banco ou uma cadeira, as mais velhas cortam a verdura e conversam, enquanto as abiãs ficam sentadas numa esteira ou no outro quarto. Cada uma tem uma bacia e corta o quiabo seguindo uma técnica antiga que virou tradição do terreiro.

O quiabo deve ser cortado em rodelas bem finas, com graça, concentração e em um estado de espírito tranqüilo. Ao longo da preparação as mulheres pedem a Xangô força e proteção neste mundo tão difícil. Naquela quarta-feira, uma abia ${ }^{54}$, que visivelmente estava em processo de aprofundamento místico-ritual, de repente ficou imobilizada com a faca na mão, como se não conseguisse continuar. Mantinha o olhar parado e distante, parecendo ter dificuldade na respiração. - "É a proximidade do deus!" - diziam, baixinho, as mais velhas.

"É assim, cortar quiabo é um negocio serio, dá força. Olha ontem comecei cortar lá pelas 21 horas e hoje comecei cedo. Devo tudo a ele, ao meu senhor, ele me deu uma casa; dinheiro nunca me faltou para alimentar meus filhos. Ele sempre me ajuda na luta, que a vida, filha, é luta. E, olhe lá, uma mulher deve ser independente de marido. Com eles nunca se sabe, não prestam, homens não prestam... e de dinheiro. Quando precisei, Xangô sempre me ajudou a mim e à minha família" - Assim me falou uma sacerdotisa.

Após ter cortado todo o quiabo, que é supervisionado por uma sacerdotisa com o grau de ebômi, deve-se preparar a cebola e o tempero e pôr tudo para cozinhar. É quase sempre a mesma

\footnotetext{
${ }^{52}$ Amalá é a comida ritual de Xangô, feita com quiabo, camarão seco, cebola, azeite-de-dendê e sal.

${ }^{53} \mathrm{O}$ peji é o altar do orixá ou o quarto que contém os altares (assentamentos).

${ }^{54}$ As abiãs são as pessoas que estão começando o percurso religioso. Já passaram por alguns rituais, como o das contas lavadas e o bori. Algumas têm o santo assentado.
} 
velha sacerdotisa que cozinha, experimentando o sal e o tempero com um grande sorriso: "Ele gosta de sal e de um bom tempero!".

Mexendo as panelas com grande colheres de pau, ela põe atenção em tudo aquilo que faz, sorri quando está bom de sal, está satisfeita por ser a cozinheira de Xangô. As outras mulheres continuam conversando, contando casos íntimos ou relatando alguma história. É tudo muito divertido e alegre; Xangô gosta de alegria e de ter muitas mulheres por perto. "O nosso rei está feliz quando toda esta mulherada esta perto, ele gosta de ser cuidado e de um bom amalá".

Quando finalmente a comida fica pronta, lá pelas 11 horas, o amalá é colocado em algumas gamelas onde é servido o cozido, enfeitando-se cada gamela com doze quiabos (o número de Xangô) e um acaçá ${ }^{55}$. Algumas mulheres pegam as gamelas e, depois de terem tido a permissão, entram no quarto de Xangô e esperam o sinal da mãe-de-santo para deixarem a comida defronte ao peji. Umas vinte mulheres vestidas à moda do candomblé - com a saia de cores bem vivas ou de estamparia florida, pois Xangô gosta de cores vivas - e com o torço na cabeça circulavam entre o quarto de Xangô e a cozinha. Uma delas, após ter posto a comida no chão, girou sobre si mesma, pôs as mãos no rosto (como se o estivesse limpando), rodopiou outra vez e, após um tremor, deu o ilá, o grito do orixá... chegou Oiá ${ }^{56}$. E, como um vento sagrado, outras duas e depois três sacerdotisas, rapidamente, foram incorporadas por seus deuses ou deusas. Era um dia de grande animação, com muita gente, com muita energia, era a primeira quarta-feira do mês. Outras sacerdotisas entravam e saiam pela porta trazendo novos hóspedes e muitas pessoas aguardam a mãe-de-santo, fosse para marcar um encontro com ela, fosse apenas para bater um papo ou receber uma palavra de conforto.

Logo depois, a mãe-de-santo começou um canto em honra a Xangô, oferecendo o amalá. As sacerdotisas mais importantes ficaram na frente do peji de Xangô e, a seu lado, os demais iniciados. No final dos cantos, todo mundo se prostrou na frente do altar e pediu a proteção ao deus do trovão e da justiça, o dono do terreiro. As aiabás ${ }^{57}$ se debruçando no icá, virando-se para os dois lados, enquanto os homens se deitavam de bruços com a fronte voltada para o chão.

Ao final da cerimônia, todos saíram do quarto de Xangô e comeram do amalá e da farinha que as aiabás, saindo cozinha portando os pratos cheios, a todos ofereciam.

E então, como sempre, foi hora de muita conversa jogada fora, numa atmosfera de alegria e cumplicidade entre todos aqueles que se encontravam sob a proteção de Xangô. Um filho-desanto, de uns 50 anos, virou-se para uma filha-de-santo e disse: elegante!

- Oh! minha rainha, como vai você, há muito tempo queu não via a senhora tão

\footnotetext{
${ }^{55}$ Acaçá é um bolinho tenro de milho branco e água, deixado resfriar em folha de bananeira, simboliza a paz, a calma, o equilíbrio.

${ }^{56}$ Quando chega um orixá na Terra, depois de alguns movimentos corporais típicos, ele emite um grito que é particular de cada divindade, como que para dizer "cheguei".

${ }^{57}$ São também chamadas aiabás as pessoas que são filhas de um orixá feminino.
} 
- Eu vou bem e o meu esposo como está? Eu vejo ele sempre circundado com muitas aiabás! Não precisa mais de mim!

— Esse povo de Iemanjá ${ }^{58}$, com toda esta meiguice, observa tudo! Não é?

Os filhos e as filhas-de-santo falam entre si referindo-se às características dos orixás dos quais são filhos e se auto-elogiando com grande ênfase.

Repentinamente, a porta do quarto de Xangô se abriu e a mãe-de-santo saiu de lá, rápida, e com um andar real que demonstrava toda a importância da sacerdotisa suprema. Ela se sentou numa grande poltrona e, mais que depressa, um filho-de-santo se aproximou e falou com ela, se abaixando e pedindo orientação sobre as folhas.

Quando eu estava saindo do terreiro em companhia de um amigo que freqüentava o Axé havia muito tempo, vi o mesmo filho-de-santo voltando da mata e trazendo consigo um feixe de folhas. Mais ao longe, vi um outro que andava na frente de uma senhora, levando nas mãos uma bandeja de ferro com vários objetos, folhas e ovos. A senhora estava indo fazer uma "limpeza". Meu amigo fez o seguinte comentário:

"Tirar folha é coisa de santo homem! Nada de aiabá! Tem que descer no mato, tem que conhecer as folhas, tem que saber o horário para poder tomar as folhas, todo mundo acha de saber tudo e poder fazer tudo, mas é com o tempo que se aprende, observando e...", com uma mão faz um movimento na frente da boca e continua, "senta em cima, minha filha, entendeu? - Na verdade, eu não tinha entendido.

"Ah, se você quer pesquisar e não sabe, minha filha, observe e fique calada!"

"Então são só os homens que podem pegar as folhas?" — perguntei rapidamente.

"Olha, o candomblé é um negócio profundo e tem que participar para conhecer e entender. É preferivel que sejam os homens de santo homem a catar as folhas, mas, se no momento da procura não estão presentes, ou como aqui que é um terreiro grande, serão também as filhas de santo homens como Oxóssi ou Ogum a colher as folhas, mas sempre pessoas que saibam e que tenham axé. Não é a mesma coisa se cata folhas uma ebômi de Oxóssi ou eu".

É um dia de grande movimento como todas as primeiras quartas-feiras: alguns sacerdotes se ocupam em fazer a "limpeza" nas pessoas, outros coletando folhas, as mulheres cuidam da cozinha.

Essa foi uma de minhas primeiras visitas a esse terreiro da Bahia. A idéia que ficou desse universo foi de um mundo complexo e sutil, no qual existia uma clareza de papéis a serem desempenhados. Chamou minha atenção a exaltação de algumas características femininas assim como aquelas masculinas que serviam para dar continuidade à tradição, enfim, à vida.

A cultura ioruba é de tipo holístico e funcional: cada energia, cada pessoa, cada objeto tem uma função e um papel bem preciso. Esse aspecto permaneceu nas Américas e encontra-se no candomblé. Todos os fiéis têm de conhecer e aprender sua função no grupo. Existe uma

\footnotetext{
${ }^{58}$ Chamam-se povo de Iemanjá ou povo de Oxóssi todos os filhos e fillhas-de-santo que pertencem a um mesmo orixá, conforme um costume deixado por Mãe Aninha.
} 
complexa diversificação de papéis que segue uma lógica específica. Essa compreende o sexo do orixá dono da cabeça, o gênero do filho-de-santo, os anos de iniciação, o tipo e o grau de sacerdócio etc. Genericamente, as mulheres ocupam-se das atividades ligadas ao interior: a costura da roupa litúrgica e, sobretudo, os afazeres na cozinha. Conforme Monique Augras,

"Quem manda na cozinha são as grandes mães míticas. Lugar de transformação, onde a alquimia própria da culinária converte o sólido em líquido, o espesso em sutil, unifica o disperso e transubstancia os elementos, a cozinha guarda em seu interior mistérios uterinos, misturas de plasmas e seivas, que vão redundar em pratos saborosos, mas também construir, no mesmo processo, as identidades míticas de todos quantos compõem a comunidade do terreiro" (Augras, 1994: 4).

Os homens, por sua vez, ocupam-se das atividades externas, como a coleta das folhas, o sacrifício etc. Os músicos, os alabês, são sempre homens que não podem, e não devem, receber o orixá em transe.

Outra clara divisão dos sexos pode ser percebida ao longo do próprio rito, quando o público, não podendo sentar-se junto, divide-se entre mulheres do lado direito e homens, do lado esquerdo, como era o costume nas igrejas católicas até as reformas que vieram com o Concílio Vaticano Segundo. Tal ordem é invertida no axexê, o que claramente tem um sentido simbólico. Essa divisão entre as energias femininas e aquelas masculinas permaneceu e se padronizou com o tempo, simbolizando talvez os dois princípios da cabaça da origem, o feminino e o masculino.

A hierarquia é basicamente dividida em rodantes e não-rodantes. Os primeiros são os que entram em transe, que são possuídos pelos orixás, os segundos são os que não entram em transe, participando dos ritos com outras atribuições. Cada filha ou filho-de-santo sabe exatamente quando e o que fazer,e o mesmo ocorre com os mais jovens, como os abiãs, instruídos sobre as suas funções ao longo do ritual.

Parece-nos, ao observar um rito, que os papéis experimentados pelas mulheres e pelos homens são claramente definidos e limitados. Limites que não significam contudo a impossibilidade de se relacionarem, mas que implicam uma interligação entre si e com o todo. Sendo os ritos uma "re-atualização do ato cosmogônico" (Eliade, 1969), é necessário que a energia feminina e aquela masculina interajam para que possam originar o mundo, criado a partir da união harmônica de dois princípios , o feminino de Odudua ou, como diz Mãe Stella, de Aiyê, e o masculino de Obatalá. Esses dois princípios se encontram na dinâmica da dança de transe que se verifica através da fusão das energias da música e aquela da dançarina-sacerdotisa e em todos os rituais que são movimentados pela dinâmica das energias.

\subsection{A Estrutura e a dinâmica do mundo}

A religião nagô fundamenta-se num complexo sistema que foi reinterpretado em solo brasileiro. Neste item vou me propor a tratar apenas dos elementos mais marcantes que focalizam as idéias a respeito da organização do cosmo, do ser humano e do dinamismo das forças que se entrelaçam no sistema, pois há vários estudos sobre isso (Nina Rodrigues, 1932; Querino, 1938; 
Carneiro, 1977, 1981; Bastide, 1961; Lima da Costa, 1977; Braga, 1989, 1992; Elbein dos Santos, 1977; Verger, 1981; Prandi, 1991a, 1991b) e muitos outros que, a partir de várias abordagens, procuraram entender a religião, o ritual e o fenômeno da possessão.

Conforme Adebayo Adesanya (1958: 39), para a civilização africana é importante encontrar uma harmonia "que não seja só uma ligação entre fatos e religião, entre religião e razão, entre razão e realidade abrangente, mas também um liame entre todas as prescrições". Tudo isso pode-se aplicar muito bem ao candomblé que também procura ligar harmoniosamente todos os preceitos e o contexto sócio-cultural.

No pensamento nagô, sob Olodumare ${ }^{59}$, o deus suprema, há o arcabouço de um conhecimento pelo qual se entende que a mão divina se manifesta a partir dos elementos mais rudimentares, como a pedra, a folha, a natureza bruta, enfim. E o candomblé vai exatamente procurar encontrar e fortalecer a harmonia entre o homem e a natureza, entre o homem e o semelhante e a harmonia do homem consigo mesmo. Por isso, qualquer planta, qualquer pedra têm um sentido e uma ligação entre si.

O universo é sagrado e real ao mesmo tempo, e os fiéis "participam do mundo invisível", conforme Pâques (1991: 33), pois este mundo existe, os fiéis podem senti-lo. O mundo compõese de duas partes, o orum, o céu ou o mundo dos orixás, e o aiê, a terra, o mundo dos seres humanos. No começo os dois mundos estavam em contato, mas por causa de uma proibição não respeitada os dois mundos se separaram (Elbein dos Santos, 1977: 55):

"Em uma época antiga, quando o orum ${ }^{60}$ o "incognoscível", limitava-se diretamente com o aiyé61, o 'mundo', um ser humano tocou indevidamente o orum com mãos sujas, o que provocou a irritação de Olorum, entidade suprema. Este soprou, interpondo seu òfurufu, hálito divino, que, transformando-se em atmosfera, constituiu o sánmos, ou céu”.

Depois desta violação, o orum separou-se do aiê e a existência se desdobrou; os seres humanos não tiveram mais a possibilidade de ir ao orum e as divindades sofreram de saudade por não poderem mais encontrar os seres humanos. Assim, por causa da saudade dos dois, originouse o candomblé que em festas periódicas abre a comunicação entre os dois mundos (Prandi, 2000: 526).

O orum é um mundo paralelo ao real, e cada indivíduo, cada animal, cada planta possui um duplo espiritual e abstrato no orum. Em muitas representações encontradas nos templos, o universo é representado por uma cabaça cortada ao meio com suas duas metades unidas: a metade inferior é a Terra, enquanto a superior é o mundo dos espíritos.

Os pesquisadores que estudaram a cosmovisão iorubá encontraram um sistema de classificação do tipo daquele proposto por Durkheim e Mauss (1901, 1902). Bastide (1978) também propôs um tipo de análise fundamentada em referenciais africanos. Sabemos que a

\footnotetext{
${ }^{59}$ Sobre o distante deus supremo dos iorubás, veja-se Idowu (1982) e Verger (1964).

${ }^{60} \mathrm{O}$ orum seria o duplo do mundo real, o mundo espiritual.

${ }^{61} \mathrm{O}$ aiê dos iorubás é o mundo terreno.
} 
estrutura da cosmovisão (macrocosmo) e a do ser humano (microcosmo) são ainda mais sutis e complexas (Lépine, 1982), pois segundo esta,

"os compartimentos do universo não são apenas justapostos: eles se engendram e se encaixam num processo que vai do general ao particular e vice-versa".

Quem põe em contato e dinamiza a comunicação entre todos os compartimentos é Exu, a divindade mensageira.

Existe uma divindade suprema, o princípio único, chamada Olorum ou Olodumare que não atua diretamente na Terra, onde é substituído pelos orixás. Os orixás, segundo Prandi (2000: 20),

"(...) são deuses que receberam de Olodumare ou Olorum, também chamado Olofim em Cuba, o Ser Supremo, a incumbência de criar e governar o mundo, ficando cada um deles responsável por alguns aspectos da natureza e certas dimensões da vida em sociedade e da condição humana."

Os orixás são forças viventes que representam estes aspectos:

1) um aspecto do cosmo;

2) um aspecto social e

3) um aspecto individual.

Segundo Verger, o orixá é (1981: 19):

"força pura, axé imaterial que só se torna perceptivel aos seres humanos incorporando-se em um deles. Esse ser escolhido, o possuido pelo orixá, um de seus descendentes, é chamado seu elegum, aquele que tem o privilegio de ser " montado", gùn, por ele. Tornase o veículo que permite ao orixá voltar à terra para saudar e receber as provas de respeito de seus descendentes que o evocaram".

Cada pessoa é filha de um orixá do qual herdou características físicas, psíquicas, energéticas. Tais legações são impressas no corpo todo, mas só com a iniciação serão fixadas. Existe então uma lógica harmônica que encaixa as pessoas e os seus destinos segundo uma dinâmica que comporta as forças vivas da natureza em movimento.

Podemos concluir que os fundamentos do candomblé visam a continuidade da vida, operando com a energia sagrada à qual as pessoas pertencem e dinamizando suas forças, pois a vida é um equilíbrio entre o movimento e o repouso, entre a ação e o recolhimento. A continuidade e o equilíbrio adquire-se também através da reposição de uma força mágico-sagrada que flui em todas as coisas, plantas, animais, seres humanos, chamada axé. No candomblé são valorizadas as pessoa e objetos que detém muito dessa força. $\mathrm{O}$ axé pode aumentar ou diminuir, mas deve sempre ser distribuído entre todos os fiéis da comunidade segundo o grau hierárquico de cada um. Os ritos servem para adquirir, manter, transpor e acrescentar o axé. A mãe-de-santo numa comunidade é quem tem mais força. E é ela que coloca essa força nos seus filhos nos devidos rituais. São princípios básicos na crença do candomblé. 


\section{Capítulo 3:}

\section{A EXPERIÊNCIA DE UMA PESQUISADORA NUM TERREIRO DE CANDOMBLÉ: PROCEDIMENTOS DA PESQUISA}

\subsection{Os primeiros contatos}

Merece ser mostrados aqui o processo de desenvolvimento dos meus primeiros contatos com o terreiro pesquisado, uma vez que o meu longo percurso baiano me fez refletir muito sobre o sentido e a maneira de conduzir uma pesquisa, assim como sobre o papel e a contribuição do pesquisador nos níveis ético e político (De Martino, 1994).

Ao deixar a Itália eu não tinha a mínima idéia daquilo que era realizar uma pesquisa de campo, ainda mais em um país estrangeiro e numa área tão delicada e sutil como aquela ligada às religiões, especificamente a afro-brasileira.

Nos cursos da pós-graduação ${ }^{62}$ tinha apreendido a parte teórica da metodologia de pesquisa e como desenvolvê-la, mas sobre a parte humana, isto é, sobre como uma pesquisadora, e estrangeira, poderia se aproximar e ganhar a confiança de um grupo era uma incógnita para mim. Havia um complicador no fato de não dominar bem a língua, de não conhecer a mentalidade brasileira, menos ainda a baiana, e de pesquisar um assunto tão delicado como o

\footnotetext{
${ }^{62}$ Minha primeira pesquisa na Bahia começou em 1993 quando cursei o mestrado em Ciências Humanas na UFBA. Para o doutorado, tinha a idéia de me aprofundar no estudo das danças rituais e em especial nas das aiabás. O motivo no começo era estético e de compreensão do universo feminino, porque sempre gostei da dança africana e logo simpatizei com os orixás. Mas para o candomblé nada é por acaso, tudo tem um sentido, e também as coincidências e os acontecimentos têm uma ligação com um pano de fundo que sustenta a existência de qualquer pessoa. Logo as velhas trataram de dar uma interpretação mística para a minha escolha profana.
} 
candomblé. Mas, de outro lado, ter de enfrentar um universo cultural tão diferente me deixou mais livre para jogar em um outro plano, muito mais empático e ...sensível.

A longo da experiência de campo, a mútua confiança foi crescendo, com a construção de uma confiança e respeito recíproco sempre crescendo, melhorando minha condição de pesquisadora e meu lado humano. Lembro-me de que quando conheci Pierre Verger, ele me disse: "Minha filha, cada coisa tem seu tempo. Não queira correr, pular as etapas, tudo acontece no tempo certo." Não tinha a mínima idéia daquilo que ele quis me dizer... entendi com o tempo.

Comecei então a ir aos terreiros para observar as festas dos orixás e também as famosas "festas de largo" baianas. No dia 4 dezembro, dia de Santa Bárbara, fui ao Mercado de São Miguel $^{63}$ e ao famoso caruru originalmente feito pelas prostitutas do Pelourinho. Tudo me fascinava, sobretudo esse lado místico-religioso misturado à alegria e à festa - coisa muito rara nas festas religiosa às quais eu estava acostumada - com a participação de gente de todos os extratos sociais: ricos, pobres, advogados, prostitutas etc.

Aquele foi um ano mais para "olhar", procurando identificar o lugar eu poderia desenvolver o meu estudo. Não tinha coragem de perguntar quase nada, mas também as pessoas raramente respondiam. O ritual, as danças, a música, as cores, os enfeites, tudo lembrava algo de precioso e cintilante, que eu percebia mas não entendia. Não freei minha evidente paixão pelo meu objeto de estudo e a simpatia que as velhas de candomblé despertavam em mim, construí meu projeto cientificamente e freqüentei as festas assiduamente.

Desde o começo era clara minha dificuldade para entender realmente aquilo que acontecia no ritual - não me refiro às seqüências dos cantos e das danças, coisa já bastante complicada para mim, que não entendia nada da língua ritual. O problema foi que ninguém explicava nada e eu percebia que algo a mais estava acontecendo por ali, algo de que minha compreensão não dava conta. Naturalmente, os livros de antropologia e de sociologia iam me ajudando a compreender teoricamente a complexidade e os vários níveis de um ritual (Drewal, 1994; Geertz, 1978; Turner, 1967, 1993; Kapferer, 1979, 1987; Tambiah, 1969, 1979).

Depois do primeiro ano, percebi que não era suficiente uma relação só de "fora", quer dizer, não bastava apenas freqüentar periodicamente as festas e o terreiro. Para entender um pouco mais a sua cultura, teria que estabelecer um contato mais profundo com a comunidade, precisava compreender como as pessoas de candomblé "estão-no-mundo".

Entendi melhor também as palavras de Ernesto De Martino quando, em uma coletânea de reflexões datada de 1977, argumentava sobre a dialética que se estabelece entre o observador e o observado e falava sobre a dificuldade do pesquisador no encontro com uma outra cultura, e sobre o saber dialogar com essa, para que se possa alcançar "aquele pano de fundo universalmente humano no qual o "próprio" e o "alheio" são duas possibilidades histórica de ser humano".

No final do segundo ano tive a sorte de morar três meses no terreiro de candomblé Axé Opô Afonjá, que eu havia escolhido para a minha pesquisa, ou, como é costume dizer no

\footnotetext{
${ }^{63} \mathrm{O}$ mercado de São Miguel foi reformado há quatro anos.
} 
candomblé, que tinha ele próprio escolhido a mim como pesquisadora. Obviamente essa experiência abriu ainda mais as portas para uma compreensão do mundo do candomblé, não só como universo religioso, mas também social e racial. Freqüentei também outros terreiros para fazer uma comparação das danças e da gestualidade dos orixás ${ }^{64}$.

A experiência participante me mostrou a vida de uma comunidade, o cotidiano de um grupo de pessoas vivendo todo tipo de conflito e toda sorte de relações de amizade e solidariedade. Inaugurou em mim um novo modo de olhar: menos para o lado artístico e mais do lado das relações humanas, obrigando-me a refletir sobre o significado de ser filha-de-santo e, sobretudo, sobre a vivência no cotidiano do sagrado. Um sagrado que entrava inexoravelmente no dia-a-dia daquelas mulheres e participava com elas nos acontecimentos de suas vidas. Sem perceber comecei a me acostumar eu também com os sonhos, com os olhares das velhas e, naturalmente, fui alcançando um contato mais profundo com aquela comunidade.

Com o tempo meu interesse nas as danças foi abrangendo também a experiência do corpo no candomblé. Tinha acompanhado o percurso de muitas filhas-de-santo, observando a aproximação de muitas pessoas ao candomblé até sua entrada para fazer a iniciação, e via claramente a importância dada às sensações do corpo e aos sonhos. Via claramente as mudanças que aconteciam nas pessoas antes e depois da iniciação, percebia uma grande mudança seja postural, seja de expressão facial.

Assim comecei a me interessar pela noção de embodiment (Csordas, 1990, 1993, 1994; Stoller, 1997) e de memória corporal (Connerton, 1993) e pela noção de "presença" (De Martino, $1973 ; 1983 ; 1959 ; 1994)$. Aceitava a premissa de que a experiência humana está enraizada no corpo. Então fiz minhas as palavras de Stoller (1997) sobre a reapropriação do corpo dos pesquisadores:

"A fusão do inteligivel e do sensivel pode ser aplicada também como prática para a pesquisa. Então nas descrições dos rituais ou da comida seria interessante prestar atenção em nossos sensos também: o olfato, o tato, o gosto, a audição, a visão, a fala podem nos dar importantes informações e nos ajudar a compartilhar um pouco da experiência do outro".

Csordas (1990) sugere uma atitude metodológica que demanda uma atenção para a corporeidade até mesmo nos dados verbais, como textos escritos e entrevistas orais.

Percebi claramente o quanto era importante a experiência corporal e, diria, sensual no candomblé e quão pouco sabia-se disso. A dança e a música ritual mostravam o lado mais visível do candomblé, porém não davam aos de "fora" a idéia do percurso e da riqueza que a experiência de uma filha ou filho-de-santo enfrentava para encontrar-se a si mesmo e a seus orixá. Percebi também que no envolvimento da pesquisa eu também mudava tanto a minha postura corporal quanto a intelecção sensível deste mundo ${ }^{65}$. O valor que aquelas pessoas davam ao seu orixá, à dança, à estética, à própria experiência religiosa, às próprias intuições me chamou atenção, pois

\footnotetext{
${ }^{64}$ Freqüentei sobretudo terreiros da mesma nação e percebi algumas diferenças nas danças. Em alguns lugares, como na casa Branca, no Gantois ou no Cobre, observei coreografias diferentes, apesar de serem todos da nação queto.

${ }^{65}$ Com o tempo, passei a usar os conceitos de Stoller (1997) e comecei a dar mais atenção às minhas sensações, tentando entender com mais profundidade este mundo.
} 
elas davam valor as suas experiências e às suas vidas. Este foi um dos pontos importantes: dar valor, dar valor ao sofrimento, à experiência, á vida, muitas vezes, sofridas. E dar valor ao corpo e ao processo que tinha desencadeado a entrada no candomblé.

Pelo fato de ser o candomblé de tradição oral, os resultados dos trabalhos de pesquisa são menos imediatos que os demais, pois o registro requer participação constante e observações intensas, além de acompanhamento atento que sempre extrapola o nível da entrevista. A pesquisa da tradição oral é de execução mais lenta e exige conhecimentos profundos tanto da situação específica investigada quanto do conjunto mitológico no qual a comunidade organiza sua visão de mundo.

Pelo fato de pesquisar a experiência do corpo (individual) e as danças rituais (social), escolhi uma metodologia mais de escutar que de perguntar. As entrevistas nunca relatavam nada significativo sobre a experiência corporal, observável somente através de uma sensibilidade visual adquirida ao longo dos anos. Lentamente abriu-se para mim um mundo de valores e de situações que me sugeriam uma proximidade maior ao terreiro, porém alcançada lenta e atenciosamente, com uma necessária abordagem sensível do mundo do candomblé, que é silencioso e, às vezes, "noturno", num sentido de captação e de percepção dos outros.

Tentei me aproximar das novas etnografias feministas (Lospinoso, 1998; Mariotti, 1998), assim como das de Stollen (1989;1997), ou mesmo da de Czordas (1997), que tentam dar uma atenção mais multivocal ao mundo pesquisado.

"Desafiando a convenção da voz neutra e impessoal da autoridade etnográfica, a etnografia experimental focaliza em seu lugar os aspectos dialógicos e situacionais da interpretação etnográfica que tendem a ser banidos do texto representativo final na prática padrão" (Healey, 1996: 196).

Esses etnógrafos enfatizam o envolvimento pessoal, a multivocalidade e a fragmentação. Stoller, por exemplo, chegou a fazer parte da congregação por ele estudada no Níger (África), afastando-se da prática convencional do distanciamento e da neutralidade. Assim, esses trabalhos buscam situar não somente os observados, como ocorre nas abordagens tradicionais, mas também o próprio observador(a). A pesquisa, dessa maneira, visa a se tornar a construção de um percurso de recíproca confiança e de diálogos e encontros através dos quais os observadores(as) vão conhecendo as pessoas a serem entrevistadas.

Minha proposta foi a de deixar as pessoas falarem sobre o candomblé e deixar que o meu olhar, mais do que as entrevistas, abrangesse as situações rituais. Foi com esse ponto de vista que comecei a pesquisa para o meu doutorado, tendo muito medo e ansiedade, devidos às muitas tarefas que, eu sabia, teria que enfrentar, entre elas o domínio de uma terminologia ligada à música, à dança e à própria experiência de fé. Teria ainda que dar conta desses temas utilizando palavras ocidentais, quer dizer, fundamentadas sobre uma outra visão de mundo, a ocidental (Lühning, 1999, 2000; Nketia, 1974; Chernoff, 1985).

As narrativas das devotas do candomblé são muito cheias de detalhes e de expressões metafóricas. Além disso, nesse tipo de pesquisa deve-se garantir que cada pessoa tenha total liberdade em suas falas. A metodologia utilizada foi a de escutar as informantes que, 
normalmente, demonstram uma postura fechada perante os pesquisadores, o que se deve ao fato de estes pertencerem ao mundo da academia, que utiliza as informações colhidas fora do alcance delas, conforme me foi dito muitas vezes. Além disso, argumentam que a comunidade não ganha nada em troca com essas pesquisas. Por causa dessas queixa, por certo tempo, permitiram o meu envolvimento nas atividades da escola do terreiro; tinha a função de educadora ${ }^{66}$ e professora de italiano para as crianças, trabalho que me ajudou no entrosamento social, até mesmo com as pessoas mais fechadas.

Muito tempo depois, fiz uma série de entrevistas para recompor as histórias de vida das filhas-de-santo, e outras para ver como elas vivem e experimentam a festa e como percebem sua música e sua dança. As entrevistas deveriam abranger as pessoas que eram depositárias das tradições. Todo os grupos humanos têm alguém, quase sempre entre os mais velhos, que guarda a síntese da história do grupo. Tal pessoa é freqüentemente a indicada para ser entrevistada.

Ser mulher contribuiu muito para minha aproximação com mulheres de candomblé, que comigo se sentiam mais livres para falar de suas vidas pessoais. Contudo, se não fosse o fato de ter ingressado aos poucos como pesquisadora, muitos eventos, sensações e outras coisas seriam, e muitas ainda são, mantidas completamente secretas. A freqüência ao terreiro permitiu-me a compreensão de um diálogo secreto, de uma multivocalidade das mulheres que dificilmente seria captada se não mantivesse uma assiduidade. Por isso fiz um diário de campo que me permitiu registrar os inúmeros acontecimentos no terreiro. Além disso, foi necessário realizar uma revisão da iconografia e da mitologia dos orixás em autores como Cabrera $(1954,1974)$ Verger $(1981)$ e Prandi (2000).

Mas, para interpretar aquela realidade, foi preciso passar sobretudo pela densidade da experiência subjetiva e pela dialogicidade com os pesquisados.

Usualmente fala-se do candomblé e das demais religiões africanas frisando a importância do ritmo, da dança. Para Kapferer (1987: 202), a música e a dança são formas estéticas capazes de "structuring the structure" do ritual. Investigá-las como experiência viva é começar a descobrir um significado ontológico do ritual. Concordo com Kapferer quando ele diz (1987: 181) que "a música e a dança têm seus significados constituídos numa manifestação direta das suas experiências".

Para o candomblé, assim como para o exorcismo singalês, o ritual não é nada a mais do que um acontecimento fenomenológico das "coisas em si mesmas", que revela uma epistemologia fundamentada sobre a atenção e o conhecimento corporal, ou seja, as sensações do corpo e os sonhos.

Farei então uma ampla abordagem da metodologia da dança porque muitos de seus aspectos também são utilizados no estudo da postura e do movimento ritual.

\footnotetext{
${ }^{66}$ Essa foi a minha atividade profissional durante 10 anos na Itália, nos Centros para o Tempo Livre da Prefeitura de Milão.
} 
Para a descrição das danças utilizo a coreologia ${ }^{67}$, que é o estudo da dança associado à cultura de um povo. Tal estudo ficou famosos através das pesquisas de Lomax (1968), porém, já em 1944, Holt e Bateson ${ }^{68}$, em Forma e função da dança em Bali, iniciaram a análise das posturas corporais e danças balinesas. A análise proposta por esses autores, então, voltava-se também para a postura do corpo durante o trabalho e à própria personalidade dos balineses, no intuito de mostrar como eles se transformam nos movimentos da dança. A coreologia tentou desenvolver uma metodologia própria, cujos três pontos básicos são: 1) problemas de definição; 2) técnicas para coletar os dados da pesquisa de campo e as filmagens; 3) análise final. Sobretudo o segundo ponto foi, e ainda é, muito debatido por ser realmente difícil coletar dados e filmagens num âmbito não verbal e não material.

Existem alguns guias sobre como fazer pesquisas de campo na área da coreologia. Kurath escreveu dois deles. O Questionário de coreologia (1952), que é um guia introdutório para pesquisadores não especialistas na área da gestualidade, é dividido em três partes: planta da área da performance; movimento do corpo; e estrutura. Sua segunda publicação metodológica (1956) já é mais específica e dirigida a profissionais em coreologia ou etnologia. Os guias mais recentes são aqueles de Royce (1969), de Kealiinohomoku (1974) e de Hanna (1966), com uma abordagem mais atual porque tentaram estabelecer uma metodologia que abrangesse dois pontos: o da forma e o da função.

Outro grande e sério problema refere-se às anotações do movimento. Atualmente a anotação mais usada é a de Laban, com uma primeira versão de 1956, desenvolvida para anotar a dança moderna. O autor explica a dança como:

"(...) uma composição de movimento que pode ser comparada à linguagem oral. Assim como as palavras são formadas por letras, os movimentos são formados por elementos; assim como as orações são compostas de palavras, as frases da dança são compostas por movimentos. Essa linguagem do movimento, de acordo com seu conteúdo, estimula a atividade mental de maneira semelhante, e talvez até mais complexa, que a da palavra falada" (1978: 41).

Seu trabalho enfatiza a forma do movimento no espaço (corêutica) e a qualidade do movimento (eucinética) e ficou conhecido como "Labanotation", que, depois foi mais aprofundado como "Effort Notation". Segundo o pesquisador, a dança se compõe das combinações escolhidas, dos esforços para fazer os movimentos, da fixação deles na memória pelo habitus e de um impulso interior próprio de cada pessoa.

A maior inovação do modelo de Laban foi a possibilidade de ler o movimento seja verticalmente seja horizontalmente, mostrando o corpo no seu lado direito, esquerdo, frontal e de costas. Numa publicação posterior, incorporou quatro tipos novos de informações: 1) o valor do tempo, executado para fazer o movimento; 2) a direção do movimento; 3) a parte do corpo movida; 4) o nível de execução.

\footnotetext{
${ }^{67}$ A palavra coreologia significa discurso sobre a dança. É uma palavra que vem do verbo grego, xopeúo, dançar em círculo.

${ }^{68}$ Citados no livro de Royce, 1980.
} 
Laban esclareceu que, para compreender o movimento, é preciso abordá-lo em todos os seus aspectos corporais e mentais (1978) e que é importante ver o impacto do movimento na mente. E relatou que:

"(...)...descobriu-se que os movimentos corporais constam de elementos criadores de ações que refletem as qualidades particulares do esforço interno do qual nascem" (Laban, 1978: 33).

Laban descreveu dois tipos de movimento: aqueles em "free flow", que são fluidos, livres e que ele relacionam ao encontro com o divino; são movimentos gerados no centro do corpo e que vão na direção do externo. Já os movimentos do "bound flow", ao contrário, são do tipo bloqueados, violentos e fixos. Desse modo, "flow" simboliza a comunicação, o fluir das energias, típicos das danças de transe nas quais o possuído parece quase deslizar sobre o chão, enquanto o "bound" indica fechamento, rigidez; seria o contrário da fluidez.

Seu sistema aborda tanto as características naturais do corpo quanto a sua predisposição ao movimento. Assim, distingue as danças de tipo "deep mover", que dão mais importância à parte baixa do corpo (dança afro-brasileira), das "high mover", que enfatizam mais as partes de cima (dança clássica). A anotação de Laban é simples, pois a descrição de uma dança ritual e de transe é muito mais difícil do que anotar a descrição de um bale.

A utilização de uma única metodologia de anotações nos estudos individuais forneceria material comparativo de longo alcance, mais flexível e passível de ser usado em outras análises. Isso é pouco factível quando a descrição da dança é feita apenas com palavras; um arquivo de sinais preestabelecidos sem dúvida ajudaria os estudos comparativos e diacrônicos.

Os filmes, várias vezes, são utilizados no lugar das anotações, mas nem sempre com bom êxito, porque a filmagem mostra a riqueza e a complexidade do ritual, porém, nela perde-se o desenho do movimento puro, várias vezes oculto - como nos rituais do candomblé —, por trás das roupas sagradas de grande efeito cênico. E também nem sempre é possível filmar o ritual e a dança pertencente a ele, como no candomblé, onde são raras as possibilidades de gravar vídeos e fazer fotografias, pois isso não é permitido em todos os terreiros, e proibido no que eu estudei mais detidamente.

Por outro lado, há uma série de questões a serem consideradas na definição de um referencial teórico-metodológico para o estudo da gestualidade e da dança sagrada no candomblé. Em primeiro lugar, é preciso avaliar criticamente as contribuições e limitações das vertentes clássicas ao estudo da dança. Essa avaliação nos revela a tendência de se separar a forma do conteúdo que, ao contrário, nos estudos mais recentes de estética (Langer, 1980) estão juntos. Os estudos funcionalistas tendem a explicitar os efeitos positivos da dança para uma dada cultura ou sociedade, deixando num segundo plano a análise formal. Essa, por outro lado, tem sido tradicionalmente desenvolvida por autores de orientação estruturalista, que tendem a equiparar a dança a sistemas de linguagem. Ao fazê-lo, terminam por anular os aspectos emotivosemocionais da dança, tratada sob viés cognitivista e desvinculada do conteúdo social dos atores.

Procurando superar a dicotomia forma e conteúdo, Tambiah (1979: 121) argumenta: 
"A integração entre relato cultural e análise formal é revelada nesta mutualidade: se os principais rituais de uma sociedade estão fortemente associados à sua cosmologia, então podemos legitimamente perguntar o que a sociedade busca transmitir aos seus aderentes em suas principais performances, o que nos leva a perguntar por que certas formas de comunicação são escolhidas e usadas em preferência a outras como sendo mais apropriadas e adequadas para essa transmissão".

É claro que a forma está inextricavelmente implicada na transmissão de um conteúdo.

Minha proposta é, portanto, fazer uma etnografia da gestualidade corporal do processo ritual e das danças na nação queto ${ }^{69}$ dos orixás femininos, mais precisamente as esposas de Xangô, ou seja, as suas aiabás: Oxum, Oiá, Obá, mais sua a mãe Iemanjá. A abordagem implica a análise de vários itens: os seus significados no contexto sócio-cultural do candomblé, com um especial cuidado relativo às histórias míticas e os oriquis; as suas funções como orixás femininos, em comparação com aqueles masculinos; os seus papéis na criação da experiência do sagrado para o público e para os fiéis; em que medida as histórias de vida das filhas-de-santo se entrelaçam com os arquétipos das personalidades dos orixás e unir o universo simbólico dos orixás femininos em relação entre si; e, finalmente, como é experimentado o cotidiano das mulheres após a iniciação.

\section{1) Análise da dança dos orixás femininos}

Tal análise considerará os seguintes pontos:

a) Identificação geral = nome e tipo da dança, local e época onde se realiza, ocasião, horário e participantes;

b) Contexto sócio-cultural da dança = função e propósito, história mitológica, oriqui, cantigas, roupa litúrgica e iconografia do orixá, classificação da dança como arte, como ritual e como diversão, método de aprendizagem, nomenclatura usada pela dança e pelas dançarinas, avaliação nativa;

c) Características sociais dos participantes = organização da sistematização para o dançarino e o público: hierarquia de idade, sociedades dos homens ou de mulheres, número, idade e sexo das filhas ou dos filhos, status das filhas ou dos filhos, retribuição dos participantes, etno-avaliação daquilo que constitui um bom dançarino, papel do público;

d) Estrutura da dança e acompanhamento = música, canto, forma da dança em termo descritivos com palavras; dinâmicas e suas variáveis durante a execução dos tempos, dos ritmos, dos estilos, dos níveis espaciais, correlação entre as dançarinas e o acompanhamento, acompanhamento pessoal (incluindo canções, ruídos etc.); relação com a música, instrumentos, título, modo, textos das cantigas, características vocais e outros ruídos que acontecem durante a dança como grunhir).

\footnotetext{
${ }^{69}$ Decidi analisar só as danças da nação queto pelo fato de que esse assunto é grande demais para incluir outras nações. O terreiro no qual concentrei o trabalho de campo é um dos mais "tradicionais" na Bahia e, por isso, bastante representativo dessa nação.
} 
e) Análise coreográfica = cuja anotação utilizada segue aquela de Laban:

- subdivisão do corpo em movimento: passos, gestos dos braços e das mãos, expressão facial etc..

Sobre os fatores básicos do movimento:

- tempo, entendido como a duração na qual o movimento se processa, e em sua dependência quanto à velocidade, distinguindo-se as tipologias: longa (tempo lento) e curta (tempo rápido);

- peso, entendido como peso do corpo, que segue a lei da gravidade e da força, que seria a quantidade de energia gasta, distinguindo-se as tipologias: forte - normal - fraca, e os acentos, a ênfase na execução dos movimentos (ênfase no neutro) e os grau de tensão (de tenso a relaxado, deslocamento do peso e relação do corpo com a terra, deslocamento no ar);

- espaço, direção que o corpo alcança, isto é, a definição espacial do corpo em três níveis: alto, médio e baixo, níveis horizontais e verticais. Analisa-se com a Kinesfera, a esfera cinética do espaço pessoal, cujas extensões são: perto - normal - longe e pequena - normal - grande;

- fluência, que é a fluência do movimento, distingue-se em fluxo: indo - interrompendo detendo;

— Corpo: movimento - séries de posições - posição.

f) Características estilísticas = grau de predeterminação, improvisação ou não; estado emocional dos participantes; comunicação com os outros dançarinos e com o público; configuração da dança como pura, abstrata, simbólica, pantomima, dramática; códigos simbólicos dos gestos da dança para o público entender; diferença de comportamento entre os dançarinos.

g) Material associado com a dança = descrição do ambiente: lugar, chão, área, espaço; visão do público; material associado com a dança: fogo, velas, luz natural; com as decorações: altar, objetos funerários, coleta de frutas, incenso; com a atividade: aspersão de água, banquete, distribuição de comida, doação de presentes, sacrifícios, estimulantes.

A descrição de nossa pesquisa se deu por meio de palavras, gráficos, desenhos e algumas fotografias, quando for possível.

A observação do gestual se deu na vida cotidiana do terreiro, enquanto a da dança foi feita no contexto ritual, a fim de percebermos como o movimento rítmico atua no espaço cênico e como se dá a intercalação da dança com os demais meios utilizados no ritual: música, objetos, ofertas, roupas etc. Além disso, visitas sistemáticas foram feitas na casa escolhida e em outros terreiros.

Para um estudo deste tipo foi basilar a aprendizagem da dança para poder expressar com mais precisão os passos e a simbologia.

\section{2) Experiência do corpo e da dança extática}

Essa dimensão da pesquisa buscou entender como os fiéis vivenciam e interpretam a experiência do corpo e da dança dos orixás femininos, que é, antes de tudo, uma experiência de 
transe. Envolveu uma atenção corporal aos fenômenos "místicos" que iam acontecendo. Foram feitas:

a) Entrevistas com membros do terreiro - filhas ou filhos-de-santo, alabês, os músicos, aos quais foi solicitado que descrevessem e comentassem sobre a dança dos orixás femininos em rituais organizados há pouco tempo;

b) Entrevistas extensas com filhas dos orixás femininos - buscaram remontar à história das relações entre aquelas pessoas e o orixá. Tais entrevistas forneceram a captação das recriações da personalidade dos orixás feitas por seus filhos ou suas filhas-de-santo e a possibilidade de exprimir a própria criatividade na construção da dança.

c) Entrevistas com pessoas que não são do terreiro - o público que o freqüenta nos ritos públicos, para entender a imagem que eles têm dos orixás.

\section{3) O cotidiano das mulheres}

Para a compreensão da experiência do cotidiano das mulheres de candomblé utilizamos os meios abaixo:

a) Observação sistemática da vida das mulheres no terreiro, acompanhando-as seja em ambiente religioso seja em sociedade (aspectos que se mesclam em várias situações). Uma atenção particular foi desenvolvida na observação da postura corporal e da sua modificação ao longo do caminho religioso;

b) Entrevistas semi-estruturadas - para captar a experiência destas mulheres e as histórias de vida, com o intuito de entender as modificações ocorridas; terreiro.

c) Diário de campo - registro quotidiano para acompanhar todo o que acontecia no

\subsection{A entrada na comunidade}

"Filha, se quer apreender a dança no candomblé, você tem que trabalhar, filha. Trabalhar e observar sem dizer nada".

Com estas palavras uma ebômi me falou um dia. Ela queria me dizer que eu deveria aprender com a prática do corpo. Porque a aprendizagem dá-se imitando, até que o corpo reproduza os movimentos certos e estes abram novas possibilidades de conhecimento e de consciência incorporada.

Ao longo de minhas idas e vindas à Bahia instaurou-se uma ligação mais sólida e duradoura entre as pessoas da comunidade e esta pesquisadora, tanto que começaram a me ver como a sua mascote. Comecei a freqüentar as preparações das festas e com isso tive entrada livre 
nos lugares mais importantes, como a cozinha sagrada, onde são preparadas as comidas para os orixás.

Comecei a observar que no ato da preparação da festa existem vários mundos fechados em si, como o da cozinha, o do barracão, os rituais mais secretos (no qual todo se harmonizavam no ritual público). Como numa grande máquina, todas essas partes iam se juntando. Mas o lado mais fascinante era próprio o aspecto corporal, os gestos repetidos, os olhares, os momentos de silencio e de alegria que demonstravam um quê de antigo e secreto.

Comecei a perceber que as coisas ditas nem sempre correspondiam àquelas pensadas ou percebidas, e também que eu tinha que dar mais atenção às minhas sensações caso quisesse compreender as entrelinhas daquele ambiente e a minha introdução no terreiro. Lendo Stoller (1997), me identifiquei com aquilo que ele chama de "corpo sensual", era justamente isso: um perceber, um entender através do corpo (como faziam as ebômis) e não apenas com a mente, então, também eu tive que começar a prestar atenção em minhas sensações e movimentos internos. No candomblé as mensagens do além chegam através dos cinco sentidos e dos sonhos, além do jogo de búzios e outros canais sagrados.

Aos poucos comecei a me adaptar ao jeito de falar daquela gente, ao seu jeito de descrever as coisas, respeitando tempos e situações. Assim,

Cheguei no Axé Opô Afonjá numa quinta-feira para trabalhar com as crianças e depois conversar com uma das velhas sacerdotisas, que parecia ter simpatizado comigo.

O calor do verão, os ônibus que tive que tomar e a minha bolsa, sempre cheia, sempre me faziam chegar atrasada; assim, entrei na casa de Xangô afobada e com sentimento de culpa por ter me atrasado. Uma sacerdotisa que estava na sala me disse para sentar, respirar e de descansar um pouco. Depois de um tempinho sai e foi para o Carrapicho ${ }^{70}$, o lugar no qual Detinha de Xangô estava me esperando.

Detinha: "E aí, chegou?"

Susanna: "Desculpe o meu atraso, mas perdi o ônibus e este calor me deixa tão cansada!"

D: "É isso mesmo! É o verão! Minha filha, aqui é tão quente e na sua terra?"

S: "Também na minha terra tem as vezes este calor! Que boneca linda: Ele é... ?"

D: "Ele é Xangô Airá. É dele que você queria falar comigo?"

S: "Sim, já falei com a senhora da minha pesquisa, não é?"

D: "Então olhe, conhecer o candomblé é difícil. Eu mesma todo dia apreendo, precisa ter muita paciência e observar. Tem o mundo das folhas, tem as lendas, tem a dança, você gosta da dança, não é?"

\footnotetext{
${ }^{70}$ Carrapicho é o nome da loja de objetos rituais de candomblé que fica no terreiro. Além dos objetos cerimoniais, vende livros, contas e sobretudo as bonecas que mãe Detinha faz à semelhança dos orixás, que são belíssimas.
} 
S: "Sim, eu gosto muito da dança dos orixás. Eu gosto deles dançando!"

D: "Eh menina, você gosta do Axé! Muito bem, muito bem!" 


\section{Capítulo 4:}

\section{A CENTRALIDADE EXISTENCIAL E O CORPO COMO FORÇA VITAL}

\subsection{A dinâmica do corpo}

Só se aprende a viver, vivendo! Mãe Stella de Azevedo Santos

A cultura filosófica e cientifica ocidental concebeu o corpo como uma realidade distinta do espírito. Foi Platão que no século IV a.C. abriu o caminho a uma nova concepção de civilização que iria moldar a cultura ocidental: o pensamento dicotômico.

A antiga lei da troca simbólica, pela qual tudo é reversível, ensinava que não existe uma linha de demarcação que divida uma realidade da outra, inclusive a vida da morte, o bem do mal, conforme se depreende destas palavras de Eurípides: "(...) quem pode saber se o viver não seja o morrer e o morrer não seja o viver?" (Platão, Gorgia, 492e-493). Mas essa concepção, a partir de dado momento, não existe mais para o ocidente. A lógica da troca simbólica estabelece uma dialética entre a vida e a morte e dessa maneira nega, além da segregação dos mortos, também aquele conceito de imortalidade da alma, conceito através do qual as religiões fundamentam a própria filosofia da salvação, com aquela carga de merecimento individual que inaugura uma lógica disjuntiva na qual o valor não se distribui na dialogicidade, mas fica tudo de um lado, o da vida contra a morte (como é para nós hoje) ou do lado da morte contra a vida (como é em Platão e, posteriormente, no cristianismo). 
Essa divisão nítida entre a vida e a morte ou entre o mundo da Terra e aquele dos espíritos é negada pelas civilizações não ocidentais porque elas temem aquilo que não pode ser trocado. $\mathrm{O}$ acúmulo de valor de um lado só é suspeito; é o lado do poder em que a reciprocidade é trocada em um "dar sem receber" e sem "restituir", o que é a sua essência. Por esse motivo, as civilizações não ocidentais trocam de tudo, com e contra os seus dons, periodicamente numa dialogicidade contínua que não permite nem que a morte seja colocada como o fim da vida nem que o nascimento seja o seu começo. Dessa maneira, o corpo que não é percebido segundo uma lógica disjuntiva torna-se um centro de irradiação simbólica no qual tudo é trocado. Dispersamse as energias que poderiam se tornar funestas, caso a comunidade não soubesse dispersá-las na troca. Entende-se aqui que o "símbolo" não é um conceito nem uma estrutura, e sim um ato de passagem no qual qualquer coisa passa para a jurisdição do grupo.

As culturas tradicionais concebem o nascimento e a morte não como um fato biológico, mas como uma relação na comunidade e para esta. $\mathrm{O}$ morto vira antepassado e deve ser nutrido para ser incluído no grupo social e poder exercer a sua função na sociedade. Por isso a morte é a continuação da vida e essa não é o único valor absoluto (Prandi, 1999b; 2001a).

Entretanto, depois de Platão a "alma" recebeu um excesso de valor simbólico que reduziu o corpo ao silêncio e a algo sem importância. Mas o corpo foi e é percebido bem diferentemente nas culturas tradicionais, como nos esclarece o antropólogo M. Leenhardt (1947) em seu ensaio La personne et le mythe dans le monde mélanésien, no qual relata a famosa resposta que um indígena melanesiano deu a um missionário quando lhe perguntou se os missionários trouxeram a noção de espírito para eles:

"O espírito? Não, vocês não trouxeram para nós o espírito. Nos já conhecíamos o espírito... O que você trouxeram foi o corpo".

Para aquele indígena, o corpo não era uma entidade anatômica que a gente está acostumada a isolar das outras entidades que compõem o mundo objetivo e que identificamos como o lugar da singularidade de cada indivíduo, mas sim o centro da irradiação simbólica para o qual o mundo natural e social foram moldados, segundo suas possibilidades. E o corpo orientavase no mundo através daquela teia de símbolos com a qual organiza o espaço, o tempo e a ordem de sentido das coisas. Dessa maneira, não se trata de um corpo isolado, mas sempre um corpo cósmico e em diálogo com sua própria comunidade. Daí advém a circulação de símbolos, na qual cada um desses corpos encontra o seu "lugar". Esse corpo comunitário, porém, não é o meio através do qual os corpos se comunicam, mas o "lugar" no qual se mostra o sentido. Cada corpo compõe uma parcela do corpo comunitário e nele circula a ordem simbólica que, por sua vez, compõe as energias do corpo humano com aquelas dos outros seres humanos, dos animais, da terra e do céu.

Assim podemos perceber o sentido dos ritos de iniciação nos quais a vida e a morte simbólica não são mais algo de individual, mas viram fatos "sociais" (a morte iniciática é recebida e, então, é reversível na troca). A vida é moldada e re-significada nos rituais iniciáticos, pois sem isso ela permaneceria um acontecimento em "separado", experimentada somente pelo indivíduo. 
Então é fácil compreender o estranhamento daquele indígena diante da noção de corpo trazida pelo missionário. Uma noção absolutamente nova, fundamentada na naturalidade biológica e expressiva da singularidade do indivíduo separado da comunicação com a natureza e com a cultura. Para o melanesiano, o corpo era tanto mais individuado quanto mais se deixava penetrar pelas forças sociais e naturais. Essas eram objeto de um intenso investimento afetivo, no qual o corpo jogava as suas energias, permitindo o funcionamento dos símbolos.

Assim com a circulação simbólica, o corpo não era dividido entre natureza e cultura, pois aquilo que para nós são acontecimentos naturais (como nascimento, mortes, fenômenos atmosféricos etc.) os símbolos encarregam-se de transformar na ordem cultural dos ritos, das práticas religiosas que reestruturam sistemas ameaçados de desordem. $\mathrm{O}$ corpo é, portanto, o ponto de conjunção entre as energias naturais e a cultura e, por meio do ritmo traduzido em dança, transforma os eventos naturais em significados culturais. Cada gesto mostra o sentido de um símbolo, criando assim a dialética, o fluir dinâmico do ritual.

Contudo, se o ritmo e a dança põem em comunicação a ordem da natureza com a cultura, evocando o divino, a respiração ${ }^{71}$ põe em acordo o interno com o externo, a matéria com o espírito $^{72}$. A respiração é a continuidade de um corpo, e seu ritmo, segundo suas modificações, expressa a calma, a ansiedade etc. que pertencem ao corpo. Não se reduz apenas à manifestação dos estados intensivos do corpo, mas é a expressão de um sentido que é a própria exteriorização.

O corpo, assim, é percebido como o lugar no qual se origina o sentido e que permite que os símbolos circulem naquele significado flutuante (Galimberti, 1987: 21) que é ele mesmo, e que representa o universo e a polissemia do mundo, pois está enraizado nesse mundo. Entendemos como significado flutuante a experiência do corpo que o deixa aberto às percepções e aos sentidos, num movimento de abertura e fechamento organizado pela respiração e pelo ritmo.

A gestualidade e a dança podem ser entendidos então como uma linguagem, ou como uma outra possibilidade da palavra (Leite, 1995-1996) pois é o corpo que fala ao grupo social.

Se nas civilizações tradicionais o corpo é percebido como significado flutuante, no Ocidente e nas grandes cidades ele se torna algo de frio e mecânico, pois quebra a comunicação com o mundo natural e social. Assim, o princípio de realidade que Platão inaugurou é o efeito de uma disjunção entre aquilo que possui valor e aquilo que não o possui; um termo é positivo somente pelo fato de negar o outro, que se transforma em seu imaginário negativo.

Dessa dicotomia originou-se uma concepção do corpo como sendo uma realidade parcial, distinta do espírito. O corpo passa a ser considerado como uma coisa que está submetida à alma.

\footnotetext{
71 Foi ainda pouco sublinhada a questão da respiração nas religiões afro-brasileira. Embora se conheça sua importância no Oriente (pode-se alcançar um estado de êxtase através da respiração), nunca se deu importância a ela na religião dos orixás. A troca da respiração é um dos primeiros sinais de uma mudança de atenção voltada não mais para o externo, mas para o interno, para a própria interioridade. Os masais, um povo do Kênia, executam uma dança na qual a comunidade toda dança em círculo com a respiração diafragmática, movimentando o corpo todo como uma onda .

${ }^{72}$ Talvez por isso a língua grega utilizava a palavra $\pi v \varepsilon v \mu \alpha$ e a hebraica, a palavra ruah, que são usadas seja para definir a respiração do corpo seja o espírito.
} 
Desenvolve-se assim uma concepção mecanicista do corpo, visto como um objeto, um mosaico feito de partes sem nenhuma ligação entre elas, reduzido a uma funcionalidade ou a uma pura instrumentalidade. Mas esse corpo dividido, fragmentado, possui uma motricidade, uma percepção, uma comunicação, uma afetividade. Como então restituir-lhe à "vida"?

$\mathrm{Na}$ Franca alguns filósofos tentaram superar o dualismo corpo-espírito, fundamentado no cartesianismo. A análise fenomenológica dessa problemática foi desenvolvida por Marcel (1953), Sartre (1953) e sobretudo por Merlau-Ponty (1994), que propõe o abandono do ponto de vista dicotômico da filosofia tradicional e da ciência, pois essa visão enrijece o pensamento nas contraposições, deixando-o numa posição fechada, longe da experiência e da vida.

Com o conceito de "corpo próprio", Merlau-Ponty aponta para uma concepção do corpo como estrutura original, não pertencente nem à ordem da "coisa pura" nem a ordem da "idéia pura". Propõe, antes, o corpo como o lugar que integra o "em-si" e o "para-si", onde o "verbo" se faz "carne" e a "carne" se faz "verbo".

Nesse sentido o corpo não se apresenta simplesmente reduzido a uma realidade fisiológica, mas como modo singular de meu ser no mundo, veículo da minhas intenções. $\mathrm{O}$ corpo está enraizado no espaço como uma experiência vivida, dinâmica e significativa e não como uma simples coisa. É algo animado pelos afetos, pela sensibilidade motora e perceptiva que se abre ao mundo e aos outros. Merlau-Ponty, com esse conceito de "corpo próprio", nos demonstra como aquilo que antes era marcado pela exclusão e pela antinomia, se desenvolve no corpo num entrelaçamento e num engajamento com o mundo. Com isso percebemos a importância dada às relações entre interior e exterior, subjetividade e objetividade, representação e sensibilidade.

Assim, o tema do corpo inserido na existência nos revelará o que há de mais expressivo na vida humana: o reino do possível e da factilidade. Uma das características do "corpo próprio" é a da espacialidade, mas de situação e não uma espacialidade de extensão, exterior, mera justaposição de partes. A espacialidade do "corpo próprio" difere da concepção cartesiana que implica uma "espacialidade de posição", na qual os objetos encontram-se justapostos, mantendo entre si uma relação de exclusão; ela delineia-se, porém, através de um "esquema corporal" no qual o corpo encontra-se orientado para o mundo e comprometido com ele. Segundo o pensamento dicotômico cartesiano o corpo está separado da consciência e por ser tomado como coisa, apresenta uma espacialidade própria das coisas. Pelo contrário o corpo mostra uma abertura para-o-mundo e as coisas, que é, uma "comunhão" para a qual, o interior e o exterior são inseparável e se confundem: o mundo é tudo dentro de me e eu sou tudo fora de me.

Pelo fato de o corpo se movimentar, deslocando-se no tempo e no espaço, a motricidade é o modo do corpo se por no mundo. $\mathrm{O}$ "corpo próprio" tem uma espacialidade de situação que implica a possibilidade de ação, pois sem motricidade a espacialidade seria algo sem sentido e o corpo se desenvolveria em um fragmento de espaço. Assim existe uma estrita relação entre espacialidade e motricidade.

Portanto, o corpo não está submetido passivamente ao espaço e ao tempo, mas ele os vive ativamente, tomando-os no seu sentido originário. "Por isso não se deve dizer que o corpo está 
dentro do espaço, nem que ele está dentro do tempo. Ele habita o espaço e o tempo" (Galimberti, 1987).

Essa cumplicidade entre o corpo ativo e o espaço-temporalidade é aquilo que dá a possibilidade ao mundo de se transformar, o que nos mostra que a "natureza do homem não é só

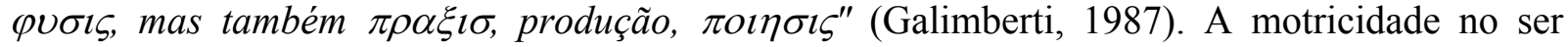
humano é expressão do vivido, pois além do físico ou do biológico há mais ser. Em toda a motricidade humana há um sentido que supera as propriedades físicas e biomecânicas, porque há nela algo mais complexo e mais amplo.

Desse modo, com a experiência da espacialidade e da motricidade do "corpo próprio", entendemos o corpo como abertura essencial para o mundo, estando em tensão dialética e dinâmica com esse. Meu corpo coloca-me em relação com qualquer coisa, se estiver aberto para o mundo. Mas depara-se com algo que se manifesta como portador de um comportamento vital, o que significa que isso é qualquer coisa de singular no meio do mundo, pois é possuidor de uma significação.

Nessa experiência de abertura para o mundo, encontramos outros corpos que, por meio de reações, expressões, linguagem, cultura etc., nos são familiares e com os quais podemos interagir através do prolongamento de suas intenções. Esses outros corpos coabitam o mesmo mundo que o nosso e vivem conosco nesse mesmo espaço-tempo, mantendo relações portadoras de sentido, possibilitando a comunicação e permitindo, desse jeito, que criemos, nos seus vários desdobramentos, o mundo da intersubjetividade.

Sintetizamos com as palavras de Merlau-Ponty,

"...O corpo é por excelência o modo de ser do homem no mundo, modo peculiar de quem está-no-mundo-para-alguma-coisa, ser práxico, sinal de um projeto, intencionalidade operante, vocação de abertura ao outro, coexistência de consciências engajadas, instauradas sobre o solo originário da percepção, animado pelo desejo, mediado pelo simbólico e pelo trabalho, singular possibilidade de ascensão do mundo humano ao mais humano" (1994).

O desafio de Merlau-Ponty é combater a visão mecanicista de Descartes. O corpo é um agente e é a base da subjetividade humana. A chave de seus estudos é a percepção, a qual é vista como uma experiência incorporada. Ela não é uma representação interna de um mundo exterior e ocorre, antes, no mundo que na mente. Assim, a percepção visual de um objeto se dá entre esse e o corpo daquele que percebe, não havendo "dois" objetos. Por outro lado, Merlau-Ponty rejeita a dicotomia mente-corpo. O corpo vê e é visto, ouve e é ouvido etc. Ele é a presença visível, tangível de cada um. Além disso a percepção se fundamenta no comportamento, em ver, ouvir, tocar, por exemplo, enquanto formas de conduta baseadas em hábitos culturais adquiridos. Assim, o relato de Merlau-Ponty não trata de nossa experiência da incorporação, pois ela não é experimentada, é a própria base da experiência. Experimentamos através da nossa incorporação sensível e sensorial. Nosso corpo é o nosso modo de ser (estar)-no-mundo, pois é o terreno da experiência e não objeto dela.

Csordas (1990) fundamenta sua abordagem teórica ao corpo postulando que ele não é um objeto para ser estudado em relação à cultura, devendo, antes, ser considerado como sujeito de 
cultura. Para ele, uma teoria da prática necessita se assentar no corpo socialmente informado, pois o paradigma da incorporação levará ao desaparecimento das dualidades mente-corpo e sujeitoobjeto. Csordas sustenta ainda que os estudiosos têm considerado a percepção como uma função da cognição, e raras vezes, a têm colocado em relação com o self e as emoções, uma vez que focaram, sobretudo, a percepção visual, isolando os sentidos, examinando raramente a síntese e inter-relação dos sentidos na vida perceptual. E como crítica principal, sustenta que os estudos anteriores não ligaram o estudo da percepção ao da prática social.

Enquanto os estudos sobre a percepção são relacionados às categorias e às classificações perceptivas, Merlau-Ponty debruçou-se sobre a sua constituição. Para ele a percepção começa no corpo e, através de um pensamento reflexivo, chega aos objetos. Quando se trata de percepção não existe a dicotomia objeto-sujeito, simplesmente, estamos-no-mundo. Assim Merlau-Ponty propõe que a análise comece com um ato pré-objetivo de percepção, mais do que os objetos já constituídos. Ele mostrou que a percepção está sempre incluída no mundo da cultura de um jeito que esse ato pré-objetivo não implique um ato pré-cultural.

Nesse ponto Csordas introduz a ênfase de Bourdieu (1977) no corpo socialmente informado como a base da vida coletiva. O interesse de Bourdieu sobre o corpo desenvolve-se no domínio empírico da prática e é paralelo e compatível com a análise de Merlau-Ponty sobre o domínio da percepção. Para unir a compreensão de Bourdieu de habitus como um conjunto de práticas inconscientes à noção de Merlau-Ponty de "pré-objetivo", o autor afirma que o embodiment não precisa ser restrito a uma micro-análise, associada geralmente à fenomenologia, mas que é também algo importante para os grupos sociais.

Csordas (1990) sugere que, definindo a dialética entre consciência perceptiva e práticas sociais, chega-se à elaboração do embodiment como um campo metodológico. É entre essa dialética que nos movimentamos desde a compreensão da percepção como um processo corporal até chegarmos à "Noção de modos somáticos de atenção", que pode ser identificada na variedade das práticas culturais. Essa "Noção dos modos somáticos de atenção" nos fornece a possibilidade de uma análise sobre nossos próprios conceitos analíticos, assim como sobre o status conceptual de "indeterminação" no paradigma do embodiment e na etnografia contemporânea.

Mas qual é o papel da atenção na constituição da subjetividade e intersubjetividade como fenômeno corporal? Segundo Merlau-Ponty, a atenção constitui os objetos fora de um horizonte indeterminado $^{73}$. Csordas, por outro lado, sugere que esse lugar onde a atenção fica é precisamente o ponto ambíguo no qual o ato de constituição e o objeto que é constituído encontram o horizonte fenomenológico. Se é assim, os processos nos quais nós prestamos atenção e reificamos nossos corpos são de grande interesse e, segundo Csordas, não é nem arbitrariamente nem biologicamente determinada, mas é constituída culturalmente. Esses são os processos ao quais nos referimos com os termos "modos somáticos de atenção", elaborados culturalmente para e com o próprio corpo, no ambiente externo que inclui a presença incorporada dos outros.

\footnotetext{
${ }^{73}$ A experiência dos nossos próprios corpos e aquela dos outros deve ficar em algum lugar no horizonte.
} 
Como a atenção implica seja um engajamento sensorial seja um objeto, temos que enfatizar que nosso trabalho se refere tanto a uma atenção "com", quanto "para" o corpo. Apontar para uma sensação corporal não é apontar para o corpo como um objeto isolado, e sim à situação do corpo no mundo, quer dizer, indicar o milieu intersubjetivo que origina aquela sensação. A noção dos "modos somáticos de atenção", portanto, amplifica o campo no qual analisamos fenômenos de percepção e de atenção e nos sugere que dar atenção a um corpo (não só ao nosso próprio corpo) pode nos dizer muito sobre o mundo e sobre aqueles que nos circundam, pois não somos subjetividades isoladas dentro de um corpo, mas estamos em constante relação com outras pessoas, sendo nossa preocupação a elaboração do engajamento sensorial. Por exemplo, a elaboração cultural dos movimentos corporais ou da forma corporal etc.

Esses "modos somáticos de atenção" também podem ser associados a grande variedade de práticas e fenômenos culturais. Mauss (1950), já havia falado sobre algo que chamamos "modos somáticos de atenção", associado com a aquisição de técnicas corporais e que eles estariam situados no horizonte cultural onde essas técnicas são desenvolvidas.

O senso da contingência e da transcendência somática ligadas à meditação e os estados místicos também poderia ser colocada dentro desse campo.

Nesse sentido, a experiência corporal é o ponto de partida para analisar a participação humana no mundo cultural. O corpo desenvolve culturalmente uma serie de "modos somáticos de atenção" e tal noção vem do entendimento de que existem outros modos de atenção alem do olhar e da compreensão mental das coisas. A nossa atenção, no entanto, está posicionada no corpo através de uma série de experiências sensoriais que atentam o mundo.

Csordas, ao analisar as experiências sensoriais na pesquisa sobre as terapias de Cura dos carismáticos (1993), sugere a interpretação do transe e dos estados alterados de consciência com outras categorias, sabendo, de antemão, ser mal-equipado para a interpretação desses fenômenos. Assim, ele apresenta essas categorias dentro dos "modos somáticos de atenção", além dos cinco sentidos básicos:

a) a intuição, que abrange a vidência e pode ser entendida como um conhecimento incorporado; e ele propõe compreender os fenômenos reveladores como uma intuição sensorial;

b) a imaginação, que foi sempre analisada como uma imagem visual, mas que pode ser também táctil, olfativa e audível, assim como incluída nos fenômenos reveladores como síntese corporal e com a qual Merlau-Ponty (1994) descreve as características da consciência humana que projeta se mesmo no mundo cultural;

c) a sensação como outra categoria para a compreensão de uma serie de fenômenos. A sensação é tipicamente empírica e força una concepção de significado cultural como significado referencial imposto sobre um substrato sensorial.

Os sentidos nas experiências religiosas, conforme várias pesquisas, são integrados e a percepção não é só o contato com o dado empírico, mas uma imagem, uma Gestalt que, de repente, se propõem emocionalmente perante a visão. 
Essa abordagem dos fenômenos reveladores ou de um estado alterado de consciência precisa de uma reconstituição de significados que conjuga as experiências sensoriais do corpo com as sínteses culturais das experiências sagradas.

A indeterminação, nas nossa categorias analíticas, se revela quando encontramos os fenômenos como essencialmente ambíguos (como os "modos somáticos de atenção"). Essa indeterminação é um elemento essencial da nossa existência. Merlau-Ponty (1994: 15-16) argumenta que a síntese perceptiva dos objetos é feita pelo sujeito, que é um corpo com um campo de percepção e prática.

Csordas fundamenta a própria proposta da incorporação (embodiment) como um possível novo paradigma para a Antropologia, juntando a noção de corpo de Merlau-Ponty com a teoria de habitus de Bourdieu. Nos seus estudos, Csordas recuperou o conceito de habitus de Bourdieu enquanto uma estrutura internalizada em disposições estruturadas. O habitus (1987) seriam disposições corporais que atuam em nível infra-linguístico. A sociedade trata o corpo como uma memória e o imbui com os princípios fundamentais da cultura através de meios insignificantes, como os trajes, os comportamentos verbais e corporais etc.

Esses princípios não são incorporados conscientemente, não podem ser explícitos. "Nada parece ser menos inefável, menos incomunicável, menos inimitável e, por isso, mais precioso do que os valores transmitidos ao corpo, feito corpo pela transubstanciação adquirida pela persuasão escondida de uma pedagogia implícita, capaz de insuflar toda uma cosmologia, uma ética, uma metafísica, uma filosofia política, através de mandamentos insignificantes como "está em pé' ou "não tome a faca com a mão esquerda". (Bourdieu, 1987: 94)

A religião constrói o habitus na dinâmica corporal e na ocupação do espaço e do tempo com posturas repetidas e com tempos ilimitados. Como relatou-nos uma informante,

\section{"O tempo no candomblé é aquilo da eternidade!"}

Mauss (1974) sublinhou a importância do estudo da gestualidade humana, chegando a idealizar a formação de uma teoria de técnicas corporais e a constituição de um inventário de todas as possibilidades do corpo humano. Em suas pesquisas sobre a natureza social do habitus, ele afirmou que não existe um verdadeiro comportamento natural e que qualquer ação varia não somente dependendo do indivíduo, mas também dos diferentes tipos de sociedades, e de educações. Qualquer ato é aprendido, desde o jeito de comer, até a higiene do corpo e o ato sexual.

Segundo o autor, a própria sociedade impõe um uso determinado do corpo, ou seja, as várias técnicas corporais são sempre socialmente formadas. Apesar de enfatizar o peso do social sobre o indivíduo, Mauss não deixou de reconhecer a importância do elemento psicológico. Verdadeiro pioneiro, apontou para a necessidade de juntar uma teoria anatômico-fisiológica à uma teoria psico-sociológica do corpo. Observou que, aos movimentos individuais e idiossincráticos, juntam-se os passos socialmente aprendidos.

Há uma série de regras e conhecimentos concernentes ao candomblé como um todo, mas também aos papéis sociais e ritualísticos desempenhados por cada membro, que são 
interiorizados na forma de um saber corporal, e, às vezes, intelectivo (teórico) - não o inverso, como normalmente se concebe.

Cada filha ou filho-de-santo, no entanto, tem uma experiência própria e pessoal do orixá e dos conhecimentos aprendidos, isto é, tem-se aberto o espaço da criatividade, da inovação - e não a mera repetição, que acaba por esgotar muito da riqueza cultural. Mauss reconheceu, portanto, a forte ligação entre os estados místicos e algumas técnicas corporais, como a respiração, a qual seria um meio que ajudaria a entrar no transe. Em seu Manual de Etnografia (1972), afirma por exemplo que um estudo da dança deve decisivamente ser iniciado por um estudo da técnica corporal e comportar um estudo psicofísico do ritmo.

Não pode-se considerar o corpo só como um texto a ser lido e analisado, pois tal postura teórica subtrai do corpo seus odores, tactos, texturas, gostos e, em poucas palavras, sua sensualidade, ponto fundamental de sua experiência no mundo. Não existe, assim, a separação corpo-mente, mas antes, sua união numa experiência total.

Nessa mesma linha teórica, colocam-se os trabalhos de Stoller $(1989 ; 1997)$ que, usando a noção de embodiment, critica o pensamento escolar eurocêntrico que considera o corpo primeiramente como um texto que pode ser lido e analisado. $\mathrm{O}$ autor sublinha o fato dessa noção ser particularmente inapropriada pelo fato de que muitas vezes as pesquisas são desenvolvidas em sociedades nas quais a noção de texto ou a interpretação textual é completamente estranha. Em muitos grupos ágrafos, por exemplo, a visão não é o modo perceptivo central, enquanto os outros sentidos são fundamentais para a vivência da experiência. Através de seus escritos, ele mostra a importância da compreensão de uma "epistemologia dos sentidos" de muitas sociedades tradicionais a fim de podermos entender melhor essas sociedades-em-si-mesmas e o que suas epistemologias podem nos ensinar sobre a experiência de sermos seres humanos.

Stoller propõe que os estudiosos devem reapropriar-se de seus corpos para poderem ativar a imaginação e trazer de volta os alunos às "coisas-em-si-mesmas". Uma vez que nas academias a mente, para um longo tempo, foi separada do corpo e os sentidos, separados da sensibilidade.

Como já nos esclareceu B. Turner, existe toda uma história secreta dos corpos na história da teoria social, desde o erotismo do corpo dionisíaco de Nietzsche até a sensualidade da dança e o êxtase nos rituais de transe. Dessa maneira, também os alunos devem reformular a percepção do próprio corpo durante a pesquisa, com a fusão do inteligível com o sensível. É fundamental incorporar nos trabalhos etnográficos todos os sentidos do corpo - o cheiro, o tacto, a textura, a audição e a sensação —, sobretudo quando pesquisamos culturas não ocidentais, pois elas sustentam as memórias culturais.

Em seu trabalho sobre os Songhay, Stoller (1993) demonstra a importância dos elementos não visíveis (como o gosto e o som), que constituem importantes elementos da epistemologia daquele grupo, pois a visão nem sempre é o único sentido que ordena as experiências dos povos não ocidentais. Entre os Songhay, o cheiro, o tacto, mas sobretudo o gosto contribuem profundamente para a construção de suas experiências, significando que sua epistemologia é fundamentalmente incorporada. As bruxas e os griots songhay aprendem sobre o poder e sua história "comendo" cheiros, gostos; saboreando a textura, eis um exemplo de que o corpo é 
experienciado e não lido como um texto. Mostra também como uma pesquisa desincorporada apresenta somente alguns elementos das práticas religiosas. Sublinha, ainda, que apreendeu o conhecimento sobre a bruxaria entre os Songhay não através a leitura de textos, e sim por meio do conhecimento e o domínio do corpo, através das vicissitudes do sofrimento e da doença.

Stoller sublinha que o corpo é um corpo que "sabe", pois a aprendizagem se dá através dele.

Retomemos também o conceito de incorporação e de práticas de inscrição de Connerton (1993). A incorporação refere-se à memorização de posturas culturalmente específicas (como as posturas referente-se à hierarquia e ao poder). É através da natureza corporizada da existência social e das práticas incorporadas baseadas nessas corporizações que os termos opostos nos fornecem as metáforas pelas quais pensamos e vivemos (1993: 90). As práticas corporais envolvem uma combinação de memória cognitiva e de memória-hábito, mas é necessário compreender a "qualidade" desse hábito, isto é, como as práticas são incorporadas, pois ele é mais do que uma competência técnica, são disposições afetivas. Trata-se de uma atividade continuamente praticada e nos sugere um sentido de operatividade. $\mathrm{O}$ habito, finalmente, não é apenas um símbolo. A experiência corporizada não pode ser entendida somente por meio da mente e do modelo de significação lingüística, o que reduziria o corpo ao estatuto de símbolo. $\mathrm{O}$ significado não é somente um símbolo que existe a um nível separado, exterior às ações do corpo. O hábito é um conhecimento e uma memória existente nas mãos e no corpo, e ao cultivarmo-lo, é o nosso corpo que "compreende". (1993: 114)

Nesse ponto encontramos os estudos do etnólogo e histórico das religiões Ernesto De Margino que, na segunda parte do seu famoso texto $O$ mundo mágico (1973), analisa aquilo que ele define como drama histórico do mundo mágico, no qual a religião se coloca como um "dispositivo terapêutico", uma estrutura que fornece limites ao perigo de "perder a presença" de si mesmo.

O conceito de "presença" para De Martino origina-se do conceito heideggeriano de Dasein — o corpo presença (Heidegger, 1997) —, que desenvolve uma cumplicidade ontológica preestabelecida entre o ser e mundo. Essa "presença" não é definida, não é dada a priori, mas para a pessoa mágica de De Martino, ela é uma conquista sempre exposta ao risco da dissolução e, por isso, estreitamente defendida como valor supremo, pois pode sumir de repente. A construção da realidade mágica se desenvolve ao redor do processo de constituição da "presença" e por isso é importante entendermos todo o contexto. Apesar desse conceito estar ligado à idéia heideggeriana, possui em De Martino uma contextualização diferente em relação a sua contextualização histórica. A "presença" não é um simples material ôntico inautêntico e impessoal. (Cherchi e Cherchi, 1987: 59). O conceito de Dasein expressa mais um nível de significação diferente daquele entendido por De Martino, como ele mesmo vai precisando mais tarde, com referencia à crise do luto, quando a morte coloca em cheque a presença: " ser na história significa dar um horizonte formal ao sofrimento, objetivá-lo numa forma particular de coerência cultural, (...)., transcendê-lo num valor especial: isto define junto a presença como ethos fundamental do ser humano e a perda da presença como risco radical ao qual o homem, e somente o homem, é exposto". (de Martino 1958: 15) 
A presença é aquilo que distingue o homem dos animais, que se limitam a viver; portanto, o sinal de "ser humano" é sua "presença", que é o bem mais importante, mas também o mais frágil, porque nem sempre é possível transcender a essa fragilidade no valor. A "presença", então, é um estado ético, psicológico e social que o homem se esforça para constituir a fim de fugir da idéia, insuportável, de não ser; é um movimento natural do homem que, ao mesmo tempo que se esforça para estar no mundo funda, podemos dizer, a cultura.

Todo o capítulo central de seu livro $O$ mundo mágico, chamado, e não por acaso, de "Drama histórico do mundo mágico" poderia ser definido como uma "fenomenologia da afirmação da "presença" sobre a não "presença" (1973).

Nessa obra, o autor descreve muitos fenômenos de estados alterados de consciência na Sibéria ártica e subártica, na América do Norte e na Melanésia, como ele mesmo observa: "existe uma singular condição psíquica na qual muitas vezes os indígenas caem como se fossem naturalmente predispostos." (1973: 91).

Nesse estado, o indígena perde, por períodos mais ou menos longos e com várias graduações, a unidade da própria pessoa e a autonomia do eu, enfim, o controle de seus atos.

Nessa condição, que advém depois de uma emoção, ou até somente de uma surpresa, o sujeito fica exposto a todas as sugestões possíveis. Existem alguns estados de automatismos miméticos recíprocos nos quais uma pessoa continua a imitar os gestos do outro. Tais fenômenos acontecem como se uma "presença" frágil, não garantida, não agüentasse o choque determinado por um particular conteúdo emocionante, não encontrasse a energia suficiente para se manter presente e compreendê-lo, reconhecê-lo e padronizá-lo numa rede de relações definidas. Desse modo, o conteúdo de uma consciência "presente" é perdido como conteúdo: a "presença" fíca polarizada num determinado conteúdo, não conseguindo ir além disso e, assim, desaparece, abdicando como "presença". A distinção entre "presença" e mundo desaparece, o sujeito, ao invés de ouvir ou ver as folhas, torna-se uma planta cujas folhas são agitadas pelo vento; ao invés de ouvir as palavras, torna-se a palavra ouvida. Nesta situação psíquica, na qual a "presença" comporta-se como uma eco do mundo, é sempre possível que uma outra "presença" tome posse daquela da pessoa, e se torne o centro da ação.

Essa fragilidade da "presença" é um fato negativo, pois esse seu desaparecimento é contra qualquer construção cultural que implica sempre uma experiência, um drama, uma participação da "presença" no mundo cultural.

Mas o indivíduo que está suportando a perda da "presença" não aceita isso passivamente": uma angústia característica desses tipo de fenômeno demonstra a vontade de "ser presente" diante do risco de "não ser".

A fragilidade torna-se um problema e procura uma defesa, um resgate. Poderíamos afirmar, então, que o mundo mágico é composto por dois momentos: uma parte de fragilidade e o momento do resgate da "presença" que deseja ser no mundo. Esses dois momentos estão ligados por um movimento de dinâmica que se desenvolve nas variedades culturais.

Sempre segundo De Martino, no mundo mágico a alma pode se perder, no sentido de que na realidade, na experiência, a alma ainda não existe, mas é uma "presença" fraca que o mundo 
pode engolir. No mundo mágico a individuação não é um fato em si, mas um dever histórico e o ser-no-mundo, uma realidade a ser alcançada.

Daqui uma série de experiências, de técnicas de proteção e práticas, que expressam seja o momento do risco existencial mágico, seja o resgate cultural, e que formam, nessa dramática polaridade, o mundo histórico da magia. A própria "presença" pessoal (o ser-no-mundo, a alma) foge do seu lugar, pode ser "raptada" , "comida"; torna-se um pássaro, uma borboleta, ou seja, deve ser "recuperada" ou "fixada", "localizada".

Resumindo: o drama mágico, isto é, a luta do ser ameaçado e o resgate a ser desenvolvido num segundo momento, aparece em determinados momentos críticos como, por exemplo, momentos de solidão, de cansaço (ligado a uma longa peregrinação, à fome, à sede) e, em geral, de estresse, quando a "presença" é chamada a um esforço mais alto do que o normal. A alma poderia facilmente se perder se não tivesse uma criação cultural e, utilizando uma tradição cultural, não fosse possível superar o momento de crise e a anulação da "presença".

Através de uma série de momentos nos quais o indivíduo, após uma fragmentação da pessoa, seja em momentos de grande emoção, seja por causa de uma intensificação da fragilidade psíquica, alcança uma visão moldada pelo mito e, após uma série de contratos, entrar em dialogo com essa visão e aceitar um novo papel na sociedade: o de mago ou xamã.

Assim, o drama mágico consiste exatamente nisto: em alcançar uma relação com uma divindade que, posteriormente, se torna o nosso guia, mas que antes poderia ser uma angustiosa fragilidade; consiste também em apreender o poder de dialogar com esse e de torná-lo um ponto de força e não de fraqueza, ou seja, conquistar o poder de conter e dominar a própria fragilidade e, depois, a dos outros.

Todos os temas fundamentais do drama existencial mágico estão em contato com o tema da força. Assim como a alma - o domínio dos espíritos, do feitiço - , para de Martino, a força mágica é "um instituto no qual se exprime o drama existencial do ser-no-mundo exposto ao risco de não-ser e que se resgata desse risco" (1986: 141).

Mas, como sublinha o autor, a força no mundo mágico não é "moral" ou "física", pois tanto um quanto outro conceito, pressupõe o contrapor (garantido e sem risco) da "presença" no mundo, enquanto que na ordem mágica tal contraposição não existe como pressuposto, mas como um problema.

Além da angústia de perder a alma, existe a de perder o mundo. Junto com a experiência de uma alma que foge do seu lugar, há a experiência dos objetos que vão além de seu horizonte sensível, que fogem de seus limites e que precipitam no caos. Assim, existe o risco do desmoronar dos limites: tudo torna-se tudo, isto é, o nada aparece junto a magia, que é sinalizadora do risco, e intervém para arrestar o caos e reorganizar a ordem. A magia, então, é uma restauradora da ordem ou da crise.

Em seu livro sucessivo Morte e pianto rituale nel mondo antico (1958), De Martino analisa o lamento fúnebre no mundo antigo e na Basilicata (Itália meridional) contemporânea e o 
coloca como forma cultural cujo fim é enfrentar a crise da "presença" que ameaça a comunidade e os indivíduos que a constituem.

Para o antropólogo italiano a situação mais delicada é a experiência da morte, desafio para a "presença". A "presença" dos vivos perante a morte é aniquilada e dá origem a duas reações, duas respostas corporais no desabafo da dor:

a) imobilidade, passividade total, ou estado catatônico;

b) mobilidade furiosa, sem regra que não é controlada e na qual a pessoa exprime agressividade contra si mesma: puxar os cabelos, arranhar o rosto com as unhas, bater-se no peito, jogar-se no chão.

A partir daí a comunidade precisa devolver a "presença" para esse ser humano sofredor ou chegará a perdê-lo completamente. Deve, então, começar um trabalho terapêutico para trazer de volta a pessoa que tive o choque e ajudá-la a possuir si mesmo de novo e não mais ser possuído. Existe, portanto, um processo de perda de si mesmo e de recuperação que valoriza a experiência passada. Essa recuperação ocorre através de uma práxis religiosa que reorganiza o caos e a desordem no corpo.

Este nos parece ser o momento teórico mais importante de De Martino, quer dizer a percepção da fragilidade humana e a compreensão da religião como meio de ajuda à "presença" para que se torne dona de si mesma novamente. $O$ antropólogo coloca a religião num lugar intermediário entre ser e não ser, entre natureza e cultura, dentro e fora e, finalmente, entre vida e morte. A religião faz comunicar estas dicotomias; ela constrói um equipamento de comunicação entre as polaridades, propondo a experiência do sujeito como experiência que possui um valor. Então no ritual, através os símbolos, existe uma elaboração da experiência do sofrimento ou da doença (que é o imobilismo), enquanto a "presença" (que é movimento, ação) não é reconstituída, processa-se uma recuperação lenta e mediada pelo ritual. Mas existem momentos muito delicados, sobretudo, os relacionados ao ser e ao nada. Após sua cura, a "presença" pode voltar a agir no mundo. E essa "cura" acontece nos rituais coletivos, por meio de uma elaboração da dor pela subjetividade da "presença", que é o centro da ação no mundo, através da música, que confere ordem e permite a superação da crise com a dança que, por sua vez, expressa a experiência do ritmo que ordena através da motricidade.

A subjetividade se comunica com o grupo social e mostra a memória da própria experiência histórica e a da sociedade no mito. História que não é uma simples reposição de movimentos ou danças, mas a força da experiência pessoal encarnada nesse mundo e proposta à comunidade.

$\mathrm{Na}$ tentativa de entender a experiência corporal no candomblé, experiência que leva a fiel a uma dança de transe, propomos unir os dois conceitos: o de perda da "presença" de De Martino, e o de "modos somáticos de atenção" de Csordas, conceitos que se unem no corpo flutuante das fiéis.

No candomblé, portanto, aprendemos menos através da assimilação de um texto, do que por meio de uma reorganização do corpo que nos permite lidar com as sensações e emoções 
experimentadas na dor e na doença, num primeiro momento, e na alegria e no valor à vida, após a "cura".

A experiência corporal das fiéis que ingressam no candomblé passa por uma desestruturação e posterior reestruturação da pessoa em que é fundamental um processo de aprendizagem corporal.

Vale a pena lembrarmos que, no contexto das religiões afro-brasileiras, a pessoa não é entendida como uma totalidade, mas como um plural singular (Abimbola, 1973; Verger, 1973; Augras, 1988; Leite, 1995-1996), do qual o corpo é uma das partes que, não obstante, unifica a todas .

Essa percepção diferente da personalidade humana permite ao fiel atuar em outros papéis, tanto na vida religiosa, quanto na social. (Prandi, 1991b).

Diz Leite:

"(....) Nessas sociedades o homem é definido como síntese de alguns elementos vitais que se encontram em interação dinâmica permanente. Em generalização ampla, é possível afirmar que o homem é constituído de pelo menos três elementos vitais: o corpo, o princípio vital de animalidade e de espiritualidade e o princípio vital que estabelece a imortalidade do ser humano" (Leite, 1995-1996, pp.103-118).

O corpo, a materialidade do ser humano, possui uma parte externa e uma interna que estão numa constante relação. A parte exterior é percebida pela forma, movimento, flexibilidade etc. A segunda está ligada à noção de entranhas que, segundo Leite (1995-1996: 107): "define a manifestação de fatores naturais e sociais, abrangendo - além da explicação relativa aos órgãos e sistemas ligados à noção de vida física - a capacidade do homem experimentar sentimentos".

Os princípios de animalidade e espiritualidade, identificados como sopro ou fluido vital de origem divina, dinamiza as partes e as forças que estruturam um ser humano.

O terceiro, e último, elemento vital é o princípio de imortalidade, pois ele é inexaurível e indestrutível, "resistindo plenamente com sua individualidade e características, aos efeitos da morte" (Leite, 1995-1996: 109).

A esses três princípios vitais devem ser acrescentados os de ordem social: o nome e a socialização, com suas práticas rituais, pois assim o significado social do corpo é alcançado somente quando ele se constitui como referencial histórico, aparecendo como fator de individualização, de trabalho e de reprodução da sociedade.

No candomblé o corpo é percebido como algo flutuante, não é ligado a uma lógica polarizada, é um corpo com a possibilidade de sentir, de dançar etc., que transforma a própria força como sua base, dinamizando as experiência e sua própria existência e, principalmente, vivendo no mundo e. não fora dele, como nas religiões da salvação. 
Tendo como base o contexto cultural holístico do candomblé, o corpo está diretamente relacionado a uma divindade e, por extensão, a um dos elementos naturais primordiais ${ }^{74}$ e aos demais elementos a ele associados, como relatam Barros e Teixeira (1989: 43).

Da cabeça aos pés o corpo é percebido como um altar no qual se derrama o sangue do sacrifício e, por isso, é construído com práticas rituais ao longo do percurso religioso e da iniciação, quando necessária. Ele é considerado o templo do sagrado por excelência, pois tem a possibilidade de receber o orixá e por isso é preparado com um cuidado que mostra toda a sua importância. É sagrado porque é vivo, vida expressa através da motricidade que atua no espaço e no tempo e que comunica com os outros (aos fiéis, à comunidade), expressando, assim, o conceito central da filosofia da existência africana, "eu sou porque você é" ${ }^{75}$, conceito que sublinha a importância de cada um na comunidade e o encontro harmônico com o outro.

Cada parte do corpo humano está relacionada a um orixá; as fundamentais são: a cabeça (sede da individualidade e lugar preparado para a decida do orixá); os seios (que dão alimentos); a barriga (lugar da transformação para excelência: a geração); e os pés (que se movimentam em harmonia com a cabeça).

Existem alguns pontos de entrada onde o orixá faz sentir mais a própria energia ${ }^{76} \mathrm{e}$ influência: várias regiões na cabeça; a nuca; um ponto no meio dos ombros, e outro, no meio do peito; e, fundamentalmente, uma área ao redor do umbigo onde parece acontecer a mudança da respiração quando a energia do orixá se aproxima.

O corpo é considerado o lugar da sabedoria. Os orifícios, os sentidos, a pele em geral são órgãos de conhecimentos. A (ou o) fiel é levada a entrar em contato com estas verdadeiras "portas de conhecimento", e deve aprender a abri-las ou fechá-las e a escutar as mensagens que provém de fora e de dentro.

Tanto maior é o nível de concentração interior, maior será a possibilidade de estar-nomundo e de escutar o próprio corpo e suas mensagens. Lembramos o conceito elaborado por Thompson (1974) sobre a estética africana, mas que, devidamente desligado de um discurso artístico, poderia ser aplicado à noção de corpo no candomblé. Segundo o autor, a arte africana possui uma coolness esthetics, uma estética fria que visa sublinhar a procura de um equilíbrio interior alcançado através um processo de escuta dos sentidos, todas as partes de uma obra artística devem estar conectadas em seu interior, apesar da movimentação das partes externas.

Existe a esse propósito um fundamento que molda as idéias filosófico-religiosas dos iorubá, segundo Omófolábò S. Àjàyí (1998: 28) é a importância do dobale (que significa ele ou ela é balançada) o gún régé (ele ou ela é "simetricamente balançada").

\footnotetext{
${ }^{74}$ Para o candomblé, o corpo humano é formado pelas energias do cosmo (água, terra, mata, ar e fogo, que é percebido como o ar em movimento). Esses elementos juntam-se segundo diferentes padrões e têm significados mágicos e religiosos diferentes.

${ }^{75}$ Ciclo de aulas sobre etnomusicologia africana ministrada no Curso de Pós-Graduação em Antropologia da USP pelo Prof. Kasadi wa Mukuna (São Paulo, 1997).

${ }^{76}$ O orixá é percebido no candomblé como vivo. "O orixá é vivo. É coisa viva, entendeu, filha!". As pessoas cansavam de me dizer isso.
} 
Qualificar com tais adjetivos significa que um sujeito possui um admirável senso das proporções e de moderação (está em equilíbrio entre as qualidades negativas e positivas).

Existe, de fato, toda uma postura corporal que remete a uma qualidade interna de equilíbrio. O externo deve refletir o interno, pois a simples aparência exterior pode ser falsificada, pode corresponder a algo de não verdadeiro. A beleza exterior deve ser correlata a um bom caráter, em iorubá iwà. A esse respeito várias vezes nos terreiros baianos ouvimos dizer "aquela mulher é muito bonita", significando que o fato de ser bonita (o) não é algo ligado somente ao lado físico, mas também ao espírito, conforme nos foi esclarecido por a Mãe-de-santo e um $o b a$ da casa.

A pessoa ideal deve responder a um modelo-padrão de equilíbrio e proporção que Omófolábò S. Àjàyí chama de ìwòntúnwònsi, que significa que cada coisa deve ser balançada $\mathrm{e}$ moderada, correspondendo a um equilíbrio corporal que reflete seu interior, a um tipo de balanceamento que permita estar em equilíbrio. Nesse sentido, é comum ouvir Mãe Stella dizer: orixá é equilíbrio.

Percebe-se então a enorme importância do gesto, da postura, da voz, porque nos falam do lado espiritual.

Veja-se, por exemplo, a importância da saudação à mãe ou pai-de-santo: para os orixás femininos o dobale, o balanço de um lado para o outro; e, para os homens, o...., a saudação feita deitando-se reto, com a barriga para baixo. Veja-se, ainda, a postura dobrada para o chão, como numa posição fetal ou de recolhida, com a cabeça sobre as mãos ao longo do padê.

Enfim, existe toda uma gramática das posturas que mostram os momentos de recolhimento, o fato de alguém pertencer a um orixá feminino ou masculino, o fato de estar em uma atitude de recebimento, como no bori etc.

O corpo, portanto, é construído ao longo dos rituais para comunicar e estar acostumado a perceber os outros, tanto em nível social quanto espiritual.

Esclarece-se, assim, que o corpo é a representação física da pessoa e do mesmo modo em que a pessoa é múltipla e construída ao longo do percurso iniciático, o corpo manifesta suas múltiplas forças e é construído esteticamente para demonstrar à sociedade o nível alcançado no lado religioso e espiritual.

Como já ressaltamos, cada orixás está relacionado a um dos quatros elementos naturais: água, fogo ${ }^{77}$, terra-mata e ar. As aiabás Iemanjá e Oxum estão relacionadas ao elemento água, mas Oiá-Iansã, que na África era cultuada no rio, no Brasil virou orixá do ar; e Obá, a velha mulher de Xangô, está relacionada à mata (terra) por ser uma caçadora. Os irmãos Ogum e Oxóssi estão relacionados ao elemento mata (terra), assim como da mata é Ossaim. Oxalá é do elemento ar, enquanto Xangô é fogo, o grande mágico, como sustenta Mãe Stella. Finalmente, ligados ao elemento terra, temos os três orixás jejes: Omulu, Oxumarê e Nanã.

\footnotetext{
${ }^{77} \mathrm{O}$ fogo não é considerado uma substância primária, mas uma conseqüência do ar em movimento.
} 
A pele está relacionada com Omulu ou Obaluaê pelo fato dele ser o orixá das doenças e, sobretudo, as endêmicas.

Assim, cada parte do corpo possui um significado simbólico, como explica Elbein dos Santos (1976: fig. 7-8): a parte frontal, relaciona-se ao futuro e ao orixá dono-da-cabeça; já a parte posterior, por sua vez, ao passado. A cabeça, ori, possui em seu interior o ori inu, a parte mais interna do ori, que é formado pelo odu (o destino pessoal); pelo orixá (genitor divino e matéria de origem) e pelo Exu individual, Exu Bara. Lembramos que no ritual do bori, as oferendas são colocadas junto aos dois lados da cabeça, pontos de grande importância: ojú-ori, a fronte, nascente; ikoko-ori, o occipital, poente; apá-òtun: o lado direito; e apá-òsì, o lado esquerdo.

"Para os iorubá a cabeça é a parte mais vital do corpo humano: contém o cérebro, a morada da sabedoria e a razão; os olhos, a luz que ilumina os passos do homem pelos labirintos da vida; o nariz, que serve como uma espécie de ventilação da alma; os ouvidos, com os quais o homem escuta e reage aos sons; e a boca com a qual ele come $e$ mantém o corpo e a alma juntos" (Babatunde Lawal, 1983: 46).

E, de fato, um dito iorubá diz: "Ori buruku, kossi orixá", ou seja, "cabeça não equilibrada (ruim) não dá orixá".

A importância da cabeça está ligada também aos cuidados dados aos penteados na Nigéria e na Bahia. Os vários tipos de penteando, de trancas, enfim, de enfeites demonstram o cuidado com a cabeça, sede da individualidade. Como explica Prandi (1991a: 124), "(...) antes do culto ao deus vem o culto à individualidade do homem, à cabeça, ao que está dentro da cabeça, ao ori."

Iemanjá é considerada "senhora da cabeça", pois, segundo alguns informantes harmoniza as energias positivas e negativas; por isso, em uma de suas coreografias dança levando as mãos, alternativamente, para frente e para atrás da cabeça. Iemanjá orienta a mente de todos os seus filhos. É por isso que durante o ritual do bori $^{78}$ canta-se para ela, pois preside esse ritual. Iemanjá, por ser a mãe por excelência, protege também os seios, e se ocupa da nutrição de todos os seres humanos. Uma lenda narra a exuberância de seu corpo e de seus seios, um dos quais é maior que o outro.

O ventre, sede dos órgãos sexuais, e o útero são protegidos por Oxum. Os quadris cadeiras também são uma área sagrada do corpo humano: a bacia e as nádegas representam a fertilidade ${ }^{79}$.

Os pés, essé, estão relacionados com os ancestrais; o direito com o masculino e o esquerdo com o ancestral feminino ${ }^{80}$. E, em geral, aos pés é dada muita importância, pois indicam movimento e devem estar relacionados com a testa, o ori, como me explicou uma mãe-de-santo:

\footnotetext{
${ }^{78}$ Existe amplo registro etnográfico sobre o ritual do bori (Veja-se Querino, 1938: 63-66; Carvalho, 1984; Verger, 1981: 33; Vallado, 1999: 54).

${ }^{79} \mathrm{O}$ corpo das mulheres é representado na Nigéria por estatuetas com seios grandes e grande barriga, enfatizando assim as características da maternidade. As nádegas, amplamente usadas nas danças africanas e afro-brasileiras, sublinham a importância dessa área de forma redonda.

${ }^{80}$ No ritual do bori, literalmente dar comida à cabeça, a mãe ou pãe-de-santo toca os dedos dos pés e pergunta se a mãe e o pai ainda estão vivo. Se um dos dois já morreu, ela bota um pouco de obi no dedão.
} 
"Como poderia andar numa direção sem os meus pés e minha cabeça? Tudo deve estar em ordem cabeça, pés, coração. Senão, como seguraria a barra todos os dias, minha filha?"

A cabeça está ligada aos pés através da coluna vertebral que, como a árvore sagrada que liga o céu á terra, liga o ori e os pés.

Não podemos esquecer a importância dos pés: a iaô (a recém iniciada) deve, obrigatoriamente, andar com uma tornozeleira, símbolo de sua subjugação ao orixá. Quando ela puder, finalmente, voltar para sua casa, após ter passado dois ou três meses, segundo a vontade do orixá, essa tornozeleira cheia de chocalhos será retirada para sinalizar que ela alcançou a liberdade. Também é digno de nota a importância dos pés em várias tradições não ocidentais nas quais é ele que mostra o movimento e a dinâmica da vida.

Sete são as aberturas do corpo humano e elas se relacionam a $\mathrm{Exu}^{81}$ : cinco orifícios, mais dois (o umbigo e o centro da cabeça onde entra o orixá); essas aberturas, como por exemplo, os furos das orelhas, são defendidas por argolas com pingentes que, quando balançadas, produzem um barulho que afasta os influxos negativos. As palmas das mãos ${ }^{82}$ e as solas dos pés ${ }^{83}$ são pontos com os quais se pode perder energia ou recebê-la. Por isso, na "presença" das divindades, os fiéis viram as palmas de frente para elas. Ogum, o senhor dos caminhos, é o dono dos pés, do movimento, da vida que continua.

A voz do orixá é o kê ou o ilá, um grito emitido apenas ao longo do transe. Esse grito é o símbolo da individualidade, é a energia daquela pessoa, o som criador e individual que testemunha a identidade daquela filha ou filho-de-santo.

Os olhos por sua vez, são muito importantes, uma vez que, conforme as palavras de algumas mães-de-santo, "nos falam da alma daquela pessoa", fato visível nas estatuetas nigeriana nas quais os olhos são engrandecido ou nas pinturas feitas em ocasião da iniciação, nas quais os olhos são amplamente enfeitados ${ }^{84}$.

Ao longo da pesquisa, percebi o olhar diferente das mães-de-santo em muitas ocasiões: durante a adivinhação o olhar parece suspenso, enquanto que, ao longo do transe, os olhos permanecem fechados, indicando que a "atenção" está voltada para o interior do corpo, para uma outra dimensão, a do interior, ao inu, segundo a filosofia iorubá e conforme nossa pesquisa de campo.

\footnotetext{
${ }^{81}$ É importante sublinhar o fato de que Exu, junto com Ogum, é o guardião das entradas e das saídas. Como se pode observar numa fotografia de Verger de um assentamento de Ogum, entre os seus instrumentos há uma chave (1981: 109). Assim também o corpo humano tem entradas e saídas, lugares por onde entram as energias boas, como a comida, e outros de onde se expelem os dejetos.

${ }^{82}$ As mãos são pontos energéticos importantes. Como podemos notar em alguns rituais individuais como o do bori, ou em algumas danças de Oxumarê, usa-se o esfregar das palmas para ativar energias.

${ }^{83}$ Através dos pés saem as energias dos antepassados que estão ligados à terra, como me informaram e como podemos observar em vários rituais para os antepassados, quando, por exemplo, se oferece água à terra.

${ }^{84}$ Veja-se também o vídeo de Drewal (1991) Yoruba Performance, no qual se pode ver uma cena em que as mulheres estão desenhando sobre a cabeça e o rosto de uma mulher a ser iniciada.
} 
Parece-nos que a entrada no candomblé ofereça a possibilidade de um "processo orgânico" ligado a uma escuta do orixá que se manifesta no corpo. Mas o percurso que leva um fiel a entrar no candomblé, e no final a ser iniciado, é longo e, na maioria das vezes, sofridos e cheios de caídas e de frustrações: as famosas provas do orixá.

Depois da iniciação o fiel é ligado definitivamente ao seu orixá através da música: ele vai a reconhecê-la em qualquer lugar e em qualquer situação ao longo da sua vida.

A vida é percebida como uma dinâmica fundamentada sobre o ritmo, entendido como o pulsar da mesma:

"O ritmo é a arquitetura do ser, a dinâmica interna que o molda (...) O ritmo se expressa através dos meios mais materiais: linhas, cores, superfícies e formas na pintura, na plástica e na arquitetura (...) Através de acentos na poesia e na música; através de movimentos na dança. Com esses meios o ritmo conduz tudo no plano espiritual: na medida em que encarna-se sensivelmente, o ritmo ilumina o espirito" (Senghor, 1956: $60)$.

\subsection{O sofrimento paralisa a vida: a falta da presença}

A freqüência em algumas época quase diária ao terreiro nos permitiu de adquirir um grande conhecimento das razões que levam as pessoas ao candomblé. Quase todos os relatos manifestam várias causas que estimularam a aproximação ao candomblé: um sofrimento, uma dor, uma doença que pode ser física ou algo de fundo emocional, como a perda de alguém. Repetidas vezes, quase como se fosse uma regra, nos foi dito que se "entra no candomblé pelo sofrimento e pela dor". Vale lembrarmos de um Seminário, organizado no Axé Opô Afonja ${ }^{85}$, no qual uma famosa sacerdotisa do Gantois, ebômi Cidália dizia que "se entra no candomblé por uma grande porta e se sai só pelo buraco de uma agulha".

Parece-nos que a análise de De Martino $(1958 ; 1961)$ esclarece o que pode acontecer em algumas situações. O antropólogo dizia que:

"(...) em geral, o drama mágico, quer dizer, a luta do ser atentado e ameaçado e o resgate sucessivo, advém em determinados momentos da existência, quando a "presença" é chamada a um esforço maior do que o de costume". E continuando: "O Mundo mágico nasce somente quando a fragilidade se torna um problema, quando é percebida como uma ameaça na angústia, e quando solicita um resgate de uma ordem cultural definida que sirva como sistema defensivo para o ser ameaçado". (De Martino, 1973: 104)

\footnotetext{
${ }^{85}$ Já há três anos o Axé Opô Afonjá organiza um seminário sobre os alabês chamado Alayandê Xirê, organizado e conduzido pela ebômi Cleo Martins e pelo ogã Roberval Marino, no qual são tratados assuntos ligados sobretudo à música no candomblé.
} 
Mas para de Martino o resgate, ou seja, a resposta à "crise da presença" não pode ser um evento de caráter individual, mas comunitário.

Existem alguns momentos nos quais, por causa de um grande sofrimento ou estresse como por exemplo a morte de alguém querido - a "presença" não consegue mais enfrentar o mundo; uma certo tipo de fragmentação acontece no interior do ser humano que não consegue mais se posicionar no mundo. Nesses momentos as ansiedades, as angustias e a fragilidade dos nervos se sobrecarregam, tomando conta do ser humano.

Em Morte e pianto rituale nel mondo antico (1958), De Martino esclarece ulteriormente o seu pensamento, destacando que nas sociedades tradicionais - mas, podemos acrescentar, em todas aquelas sociedades nas quais a vida é difícil qualquer seja a causa (guerra, fome, violência etc.) - , onde o mundo antigo ainda resiste, a vida privada, no quadro da vida coletiva, está repleta de riscos existenciais que, em nossa sociedade, não possuem mais significado. Por outro lado, as sociedades contemporâneas têm em comum com as sociedades tradicionais, ou antiga, a experiência crítica da morte de uma pessoa querida ou ainda, os momentos de crise, que hoje em dia são as guerras, o despotismo das ditaduras etc.

Nas culturas tradicionais e no mundo antigo o risco da perda da "presença" assume uma gravidade e uma freqüência maiores do que na sociedade contemporânea, fato que obriga a civilização a confrontá-la para salvar a si mesma. Os seres humanos criaram assim algumas formas institucionais adaptas a proteger a "presença" do risco de não ser-no-mundo. Desse modo, a exigência dessa proteção técnica constituí a origem da vida religiosa como ordem mítico-ritual.

As técnicas de recuperação da "presença" ocorrem no mito e no rito. A ligação dialética que liga o risco da perda da "presença" com o sagrado foi já amplamente analisada na história das religiões e, em particular, por Otto (1917). A "presença" do deus seria, segundo esse autor, o "radicalmente outro" que a possui, subjugando-a. Essa alteridade, que amedronta quem a experiência, é o risco radical de "não ser", a alienação da "presença" e pode tornar-se "excêntrica", pode se isolar, e a "presença" acaba por não ser mais hábil para manter essa alteridade como outra. Começa, então, a aparecer o caráter "radical" da alteridade que se pode interpretar como sinal da crise da "presença". Mas a caracterização da dialética da ligação criseretomada da experiência do sagrado deixa uma possibilidade de recuperação (da "presença") na individuação da imagem do deus, que participa de uma tradição cultural mítico-ritual, organicamente incluída no mundo histórico no qual vive, e aberta ao valor.

O outro momento do numinoso, sempre segundo Otto, se dá com o encantamento, o fascinans. O medo de se perder, todavia chama a divindade para obter uma relação, uma reintegração no humano

Assim na experiência religiosa o deus está chamando, enquanto no mundo cotidiano o que chama é a alienação da "presença", que reclama uma reintegração na história humana.

Esses momentos de alienação são manifestados através do corpo por um imobilismo típico que leva as pessoas a uma passividade total, às vezes, a uma série de movimentos automáticos não inconscientes. Ou, segunda possibilidade, por um movimento furioso, uma autoagressividade, como já exemplificamos oportunamente. Também nas historias que conseguimos 
coletar, o processo religioso se deu com uma quebra no cotidiano, em situações nas quais as pessoas não conseguiam mais enfrentar.

Começamos com Joana, filha de Iemanjá. Ela é uma mulher jovem - na época que começou a freqüentar o terreiro, uns 6 anos atrás, tinha uns 32 anos - , branca, de classe média, filha de fazendeiros do Recôncavo baiano e medica de profissão.

Quando a conhecemos, era abiã, ela passava os dias deitada sobre uma esteira na casa de Oxalá, esperando para fazer sua obrigação. Deitada no chão, com uma mão sustentava a cabeça e com a outra acariciava seus longos cabelos. $\mathrm{O}$ rosto demonstrava um sofrimento, como se algo que a estivesse consumindo, não lhe permitindo sorrir. Às vezes ficava parada, com o olhar suspenso, sem ver nada e sem poder falar, como num estado de estupor. Toda a postura de seu corpo manifestava imobilidade e a sensação que passava era a de que aquela era incapaz de se levantar e reagir.

As pessoas do terreiro passavam, perguntavam algo, diziam algumas palavras gentis e ela ali ficava, dias e dias deitada com uma expressão de desânimo no rosto.

História de Joana, filha de Iemanjá:

"Eu sempre soube que tinha algo a fazer, que algo acontecia comigo. Já participei de outros rituais ligados às mulheres e à lua, mas sempre soube que eu antes ou depois, iria parar no candomblé.

Meu marido e a minha familia achavam que eu fosse exagerada, que tivesse algo meio assim teatral, mas que nada! Gostaria que eles tivessem passado somente um pouquinho daquilo que eu passei. Olhe, um dia, estava voltando através da Ilha, não consegui nem conduzir. Parei o carro e liguei para meu marido que veio me buscar e me trouxe até aqui no terreiro. Não conseguia nem me mexer, não sei, um negócio estranho; uma vontade de fazer nada. E aquela tontice, aquele negócio na cabeça, como se não tivesse mais forca. Todo mundo achava que eu exagerasse. Perdi o trabalho, só conseguia ficar por aqui; nem andar conseguia mais. E aquela vontade do mar, de olhar o mar; você sabe como é! Tentei reagir, mas sabia que não ia conseguir, então por que reagir, por que tentar contestar a força dos orixás? Mas que sofri, sofri; esta moleza, esta tontice, foi me pegando até eu não me mexer mais."

As demais entrevistas foram feitas com uma das mais doces senhoras que já conheci. A familiaridade que alcançei com ela me deixou mais à vontade para fazer outras entrevistas. É uma senhora de 76 anos e de família da coisa ${ }^{86}$. Formou-se em enfermagem e trabalhou em vários hospitais. Ela se define também católica. Seu pai era ogã e a mãe tinha conta lavada ${ }^{87}$, mas eles

\footnotetext{
${ }^{86} \mathrm{Na}$ Bahia, quando se fala assim, se dizer que é de candomblé.

${ }^{87}$ Conta lavada é um dos primeiros rituais do candomblé. A pessoa recebe as contas de seu orixá, lavadas com as folhas desse orixá.
} 
não queriam que as filias se aproximassem do candomblé. E assim conta mãe Almira, uma das ebômis de Oiá :

"Meu nome no candomblé é Oiatomilá. Nasci no dia 13 de abril do 1925. Conheço este candomblé desde menina, desde 1936, e me lembro ainda hoje de minha avô Aninha, que faleceu em 1938. Ela era poderosíssima. Lembro uma vez em que o Xangô dela começou a dançar e a comer orobô ${ }^{88}$, ninguém entendia o que estava acontecendo, ela mastigava, mastigava. De repente começou a cuspir pedaços de pedras, pequenos pedaços de pedra. Eu fiquei com um pedaço, mas depois não sei onde botei, Você sabe como é, eu era muito jovem, não ligava pra nada. O Xangô de Mãe Aninha fez uma verdadeira mágica; eu vi, eu e minha irmã vimos, não é?

Aos 13, 14 anos, fiquei doente. Eu tinha muita dor de cabeça e minha mãe com meu pai resolveram me levar no terreiro para ver aquilo que eu tinha e se viu que eu tinha que ser feita... Só ficava com dor de cabeça. Até na escola eu faltava de vez em quando, não agüentava mais. Assim minha mãe, minha mãe foi Mãe Senhora, me iniciou em 1941, no dia 24 de agosto. Eu tinha 16 para 17 anos. Agora são 59 anos de santo, neste ano.

Depois de três anos, virei Iasiá, quer dizer, a 'mãe que carrega a bandeira de Oxalá' (faz 55 anos que me deram esse cargo). No dia da procissão de Oxalá, no terceiro domingo, $e$ com muita felicidade, carrego a bandeira de Oxalá.

Olhe, não queria fazer santo, nem os meus pais queriam, mas tive que fazer. Ficava deitada na espreguiçadeira; não conseguia mais ficar em pé, só dormia e ficava tonta. Tentava ler um pouco, mas dai a pouco começava a dormir, vinha aquela coisa e eu me deixava ir.

Depois de ter feito o santo, nunca botei pé na cozinha do Axé, isto não, minha Mãe falava: ' não deixa essa menina ir na cozinha, ela não pode' - eu passava logo mal."

Olhe, a minha família não queria nada de candomblé, meu pai era ogã, minha mãe tinha conta lavada, mas nunca, nunca meu pai quis que a gente se aproximasse ao candomblé. Mas....tive que fazer, eu tinha um 17 anos, só dormia. Dormia direto, não conseguia mais ir pra escola, não conseguia mais fazer nada. Ficava dia e noite na espreguiçadeira e dormia, não conseguia me mexer, levantar, andar; somente aquela dor de cabeça, e nada, não conseguia fazer nada. E aí meu pais tiveram que me levar pro terreiro. Foi um caso de doença mesmo. E ai tive que me iniciar e passou tudo.

"Percebo a presença de Oiá quando me arrepiou, sinto uma tontura, mas ela me defende, ela me avisa.

"O negocio pegou também minha irmã, 60 anos de santo assentado ${ }^{89}$. Ela dormia direto, dormia, dormia. Caía dormindo em todos os lugares: na escola, em casa, na rua. Ela chegava na escola e aí logo botava a cabeça sobre os braços e dormia. Foi só ela assentar seu orixá e pronto. E depois melhorou tudo.

\footnotetext{
${ }^{88}$ Orogbô é uma semente usada em várias oferendas e rituais, sobretudo para Xangô.

${ }^{89}$ Ter o santo assentado é ter passado por uma etapa preliminar da iniciação, quando o altar particular do orixá da pessoa é sacralizado, podendo, pois, receber oferenda.
} 
"Mas uma vez não era como agora; a gente tinha que ficar no terreiro depois do assentamento, pelo menos, por um mês. Não saía logo na rua, o assentamento é um negócio serio."

Destes dois relatos entende-se que, a um certo ponto, houve um corte, aconteceu algo, um sinal, que pode ser uma doença, uma dor inexplicável, uma letargia, enfim, algo que sinaliza uma mudança entre a vida anterior e um enfraquecimento da "presença".

Mas os pedidos dos orixás podem ser diferentes; nem sempre são tão dramáticos, às vezes chegam através de sonhos ou de uma estranha moleza.

"Naquela época sonhava direto com os orixás e me sentia como se tivesse um calor na cabeça que nunca tinha experimentado antes." - nos conta uma filha de Oxum.

Tivemos a oportunidade de seguir mais de perto o percurso de uma outra filha de Iemanjá, Simone, que tinha se aproximado do terreiro para uma pesquisa cientifica. Fazia parte de um grupo da Universidade Federal da Bahia. Branca, 34 anos, intelectual de classe médio-alta, tinha viajado muito. E nos relata:

"Comecei a me aproximar do terreiro para a minha pesquisa. As festas aqui são lindas. Sempre achei as festas dos orixás muito bonitas e, assim, comecei a freqüentar a roça. Depois de algum tempo, a mãe-de-santo leu para mim os búzios. Ela tirava e sorria todas as vezes. Eu não sabia como interpretar aquele sorriso. Ela me dizia que eu tinha muita familiaridade com o candomblé e que ela não sabia explicar isso. Falou claramente que era filha de Iemanjá, mas que uma Oiá muito forte me protegia. Que eu era uma médium e que iriam acontecer muitas coisas naquele ano.

Passaram-se dois anos desde aquela primeira consulta e ia me acostumando um pouco àquela comunidade, apesar de nunca ter freqüentado uma comunidade de qualquer tradição e de nunca ter feito uma pesquisa. Achava tudo extremamente familiar e, muitas vezes, era como um reconhecer algo.

Um belo dia que eu me sentia tão cansada e temia estar pegando uma gripe, a mãe-desanto me chamou e me disse que queria olhar para mi. Nos búzios deu que eu precisava de uma limpeza, porque tinha muito olho gordo sobre de mim e ai ela me mandou fazer uma limpeza.

Foi bastante estranho porque não sabia bem no que consistia aquilo, mas depois do ritual caí dormindo na casa de Xangô, como se não pudesse mais me levantar. As pernas estavam muito pesadas e uma sensação de paz me encheu. Depois, tive várias reviravolta, tive que viajar bastante e meu pai faleceu. Muitas mudança. Foram pelo menos três anos de mudanças contínua e comecei a ficar deprimida, muito triste mesmo.Estava sempre cansada, era obrigada a andar muito e resolver coisas, parecia uma maluca. Não conseguia parar. Parecia um urubu, ia para lá e para cá.

Até que um dia a mãe-de-santo fazendo um outro jogo, viu que eu tinha que fazer um assentamento. A gente se organizou bem três vezes para fazer a obrigação, mas todas as vezes acontecia algo. 
Bem, depois de um ano consegui, de verdade, fazer este ritual que é um ritual importante. Fiz a minha obrigação sem entender nada, só dormia e sonhava. Sonhava naqueles dias, mas todos sonhos lindos.

Depois de quase um ano, durante uma festa de Xangô, comecei a sentir uma leveza estranha, como uma onda de tranqüilidade e doçura dentro de mim e uma tonteira me pegou; me sentia uma meninota e sentia uma grande vontade de dar risadas.

Depois daquele dia caía dormindo em todos os lugares, mas sobretudo nas festas. Começava com uma tontura e depois caía dormindo até uma hora.

Começou, assim, uma época muito dificil porque não conseguia fazer as minhas coisas. Tudo parecia cansativo, parecia que não tivesse mais a terra por baixo dos pés. Vivia como numa bola, assim suspensa entre céu e mar. E aquele cansaço... e que cansaço!.

E começaram os sonhos, cada noite era um sonho diferente e sempre ligado a alguma coisa da natureza. As vezes eram sobre as plantas: o suspiro das plantas, o movimento das folhas. De dia ficava horas olhando o mar. Estava complemente encantada diante do mar e das plantas. Não sabia que coisa estava me acontecendo. E quando chegava aqui logo mudava a respiração e sentia que o meu corpo flutua no ar."

Por meio desses primeiros depoimentos, individua-se um processo que começa com um cansaço que leva a pessoa a um estado de letargia e de aniquilamento, acompanhado por um sofrimento que é como se algo estivesse se consumindo no interior da pessoa. Como observamos a fiel chega a um ponto que não pode mais se movimentar nem se levantar, assim como, em alguns momentos, uma série de movimentos involuntários e quase mecânicos acontecem sem que a pessoa queira, como se o corpo seguisse um movimento ligado à natureza. A "presença" deixou seu lugar e a fiel entra num estado depressivo e apático, tudo é difícil, tudo é traumático, o mundo ao redor parece ser ameaçador e agressivo.

Algumas pessoas chegam a deixar completamente as suas atividades sociais e muitas alcançam situações problemáticas também na esfera da afetiva, econômica etc. Nesses momentos, a "presença" não se manifesta, mas cede o seu lugar aos movimentos da natureza, dando a impressão de que, em alguns momentos, o busto das pessoas flutua, como se fosse atravessado por uma onda. Os movimentos do corpo são lentos e uma estranha dor, atordoa a cabeça, tomando posse. A "presença" não consegue mais participar do mundo, mas parece ser convidada a um outro mundo, mais fluido e longínquo, que a chama para poder se manifestar e comunicar.

Joana, filha de Iemanjá:

"Tive que largar o meu trabalho, ficava horas e horas deitada, olhando pra minha frente, sem saber o que era. (A postura corporal era de uma pessoa sofrida, muito magoada. Os olhos quase fechados e ela estava deitada sobre uma esteira.) 
Aquela sensação estranha de algo que me chamava, como se estivesse hipnotizada. Sofri pra caramba! Era como se percebesse todos os sofrimentos do mundo. Olhava as caras das pessoas e percebia o sofrimento deles. Isso não era bom !"

A segunda filha-de-santo, Simone, também nos conta sobre a impossibilidade de continuar suas próprias atividades.

"Perdi quase um ano na escola, porque só queria dormir, dormir e sonhar. Não conseguia mais me esforçar, pois a minha vida sempre foi uma luta, mas queria só ficar deitada e às vezes me pegava, como uma onda, que me fazia ondular como se fosse uma cana-de-açúcar. Minha mãe estava muito preocupada e não sabia o que fazer. A coisa mais estranha era a minha resposta aos fenômenos da natureza. O corpo logo percebia e respondia sem que eu pudesse fazer nada. Um dia estava na feira de Itapuã e estava olhando uma barraca de folhas e, de repente, passei uma mão sobre um tipo de folha e....não sei, senti a energia dela. Estou ficando loca, achei! Mas um choro subiu; mas não era de dor não, era de emoção. A mulher da barraca se aproximou de mim e me disse pr' eu não ficar com medo, que era coisa boa e, afinal, esse era o dia dela. Era um sábado. A coisa que me deixava mais curiosa era como as pessoas que conhecem o candomblé, logo percebessem o que acontecia."

Uma outra filha de Oiá, Joanilda, começou a vir no terreiro. Era já uma senhora, de uma pequena aldeia do interior baiano. Negra, casada, trabalha no campo e em casa. Segundo ela o orixá queria ser feito:

"Olhe, estava lá no meu quintal, botando a roupa sobre a corda, quando de repente apareceu aquele homem sobre um cavalo empinado e eu me sentia tremer. A cabeça tomou fogo e eu chorava, chorava, meu marido não queria de jeito nenhum que eu fosse para cá, mas vou fazer o quê?. Quando ele percebe algo de estranho logo fica revoltado. Mas tenho que resolver isso. É desde menina que me chama. Olhe outro dia estava na Lapa esperando meu onibus e, de repente, formou-se um buraco em baixo dos pés e fiquei tão tonta e descontrolada que quase cai no chão. O que é isso? É ele, o santo!"

Uma filha de Oxum, mãe Valdira, feita há mais de 50 anos e já mãe-de-santo, nos contou sua história:

"Filha, o negocio começou aos 16 anos Oxum me pegava sempre, ficava tonta, virava a cabeça e eu não via mais nada. Aos 18 anos estava para me casar. Meu marido não queria saber desse negócio, ele não queria mesmo. Então, naquela época morava na Liberdade, estava na loja escolhendo o tecido para o meu vestido de casamento e caí, não entendi mais nada. O próprio santo me levou pra uma casa de candomblé aí perto. $O$ santo, ele mesmo, me levou; e eu não sabia nem quem era o santo. O santo mesmo acertou com o pai-de-santo e, em pouco tempo, tive que fazer o santo. Meu noivo me abandonou, ele não queria mesmo que eu raspasse. Mas depois de um tempo ele apareceu de novo e a gente casou. Quando a gente construiu esta casa, meu marido falou que os meus santos não entravam de jeito nenhum. Ele morreu e eles entraram. A minha 
Oiá tinha avisado ele, mas ele desafiou a santa. Ele era arretado mesmo. Mas eu sofri, e como sofri, não foi fácil para mim. Apesar de uma velha senhora tentar me acalmar, dizendo que era assim mesmo, que sempre tudo começava assim, com o sofrimento. Mas! Ainda me lembro daquela velha ebômi tão caridosa e simpática."

Parece claro nesses depoimentos o caráter peremptório dos chamados, dos avisos constantes que o orixá manda às suas escolhidas e também as mudanças de percepção das coisas, como se fosse possível ver além da realidade à qual somos acostumados. Como se as percepções abrissem para um estado de consciência mais "aberta" para ver, perceber além dos cinco sentidos habituais.

Muitas vezes os primeiros sintomas da intervenção do santo aparecem depois de um periodo de estresse ou de sofrimento, causado por motivos reais ou por algo não identificado claramente.

\subsection{O orixá se aproxima: sensações e emoções}

Conversando com as entrevistadas e analisando os fatos ocorridos ao longo de minha estada no terreiro, tive que lidar com um conceito de mediunidade muito mais abrangente que aquele que normalmente entendemos. Usualmente, quando se fala de médium, pensa-se logo em um tipo de transe no qual acontece algo de estranho, de violento, enfim, algo de visivelmente diferente do "normal". Segundo o candomblé, existe uma outra realidade além do mundo visível, que seria um mundo paralelo e correlato ao nosso, onde moram os orixás e os espíritos. A comunicação entre esses dois mundos se daria por meio do corpo de algumas pessoas especialmente escolhidas pelos orixás. Tais pessoas, devidamente treinadas, são preparadas para emprestar seus corpos aos orixás, que assim vêm à Terra para trazer conforto e paz aos humanos e com ele se confraternizar.

A mediunidade é considerada um dom divino, recebido no momento do nascimento. As informantes nos explicaram que há vários tipos de mediunidade e que os orixás podem enviar recados e energia de várias maneiras.

A mediunidade apresenta diferentes modalidades e se manifesta em intensidades variadas. O médium precisa ser educado para poder desenvolver todo o seu potencial e servir na comunicação, e assim ajudar a todos, caritativamente ${ }^{90}$. O conceito de mediunidade é direcionado e interpretado culturalmente e abrange uma grande gama de fenômenos. É associada a outros tipos de percepção, como a intuição, o pressentimento e a premonição. Esses tipos de conhecimento corporal são interpretados no candomblé como sinais dos orixás. Assim, todo mundo pode ter um certo grau de mediunidade, que em alguns momentos pode explodir ou se tornar mais fraca.

\footnotetext{
${ }^{90}$ Muitas vezes as velhas me disseram que o candomblé é caridade. Quem entra deve ajudar os outros, como os elos de uma corrente. "A gente, os escravos se salvaram assim, se ajudando, então temos que continuar!", me disse uma das velhas.
} 
Como propõe Kardec, o codificador do espiritismo, existem vários tipos de mediunidade. As pessoas chamadas de sensitivas têm uma especial sensibilidade através do tato. Esses médiuns podem perceber a presença dos espíritos através um arrepio, através de um "sentir" que alguém está por perto. Ainda segundo o kardecismo, existem médiuns auditivos, ou seja, que podem ouvir vozes que vêm do próprio interior ou não e que trazem recados. A vidência é uma outra possibilidade: pode acontecer que em alguns momentos especiais os médiuns vejam coisas invisíveis aos homens comuns. Esses fenômenos de mediunidade podem acontecer de várias modos, num estado de consciência normal ou de consciência alargada ou, ainda, por meio dos sonhos.

Uma outras possibilidade é a conexão de pensamentos. Para alguns médiuns é fácil perceber, ouvir, que alguém está pensando neles ou desejando comunicar algo. Em momentos de concentração, podem assim se comunicar com os orixás. Essa capacidade de recepção de mensagens é muito útil quando o médium está envolvido numa atividade de adivinhação ou de cura.

Almira, a ebômi filha de Oiá, conta que sempre foi muito emotiva e passional:

"Ah minha filha, eu já sofri muito. Quando trabalhava com aquele ciúme besta das pessoas, sempre alguém tinha algo a me dizer. Cansei de fazer ebó fora do trabalho. Olhe, chegavam a me dizer cada coisa. Entrava no trabalho e já ficava nervosa. Nem precisava que eles falassem nada; eu sentia aquele arrepio, aquela sensação de peso e saía do trabalho toda lerda. (Mãe Almira começa a ficar nervosa e agita uma das pernas). Saía do hospital e tinha que fazer algo para não me sentir deprimida.

A gente sente quando tem algo de bom ou de mal nas pessoas, ou se alguém tem olho gordo. A gente está protegida por nossos orixás. A gente recebe avisos, alertas. Um dia, botei na cabeça que tinha que ir fazer o mercado, e já era tarde e escuro. Me arrumo e, ligeira, saio na rua. E quando boto o pé na rua, algo me empurra para trás, e me vem aquela intuição "não saia!". E aí? Não saí."

A filha de Iemanjá, Simona, nos fala de uma época na qual estava muito fragilizada e emotiva:

"Foi um período muito confuso, muito confuso mesmo. Eu sempre gostei de criança, mas assim era demais. Eu chorava quando via uma, ficava olhando e pensava quando vai ser que terei o meu? E depois, de repente, aquela vontade de choro. E chorava, chorava horas, nem eu sei porquê; tudo me comovia, tudo era motivo de choro. De repente vinha aquela coisa estranha na cabeça, como se algo saísse dela e eu me tornava vazia e mole.

Tinha momentos que sentia uma coisa leve, como uma água que descia desde a cabeça até os pés. E ai não conseguia nem andar, uma coisa solta me pegava e me sentia uma meninota que andava na rua pulando e rodando. As vezes me pegava também uma vontade de dar risada; e ai eu ria... ria como uma maluca. Duas ou três vezes pulei no barracão.

Numa festa de São Lázaro, aí na igreja de São Lázaro, estava cheio de gente, toda aquela gente tomando banho de pipoca, sabe como é? Bem, nunca tinha visto aquilo, mas por 
baixo de um tecido branco tinha um bocado de pessoas que, vestidas como crianças, brincavam. Naquela época eu nem sabia o que eram os erês ${ }^{91}$. Bem, eles começaram a me chamar de mãe e a brincar comigo: 'Viu, mãe', diziam pulando e cuidado com você, 'mãe, está boa?' E tatatá e tatatá'. E andavam pra direita e pra esquerda, com aqueles laços todos tortos na cabeça. 'E quando a nossa mãe vai tomar conta de nós? A gente fica triste sem a senhora', e tatatatá e tatatatá, viu?

Mas o que mudou foi minha percepção sobre as pessoas; às vezes passando perto ou encontrando alguém, podia saber tudo sobre ela, sentia a energia da pessoa claramente. Se ela estava bem ou não. Nas primeiras vezes fiquei assustada: enquanto um amigo meu conversava comigo, vinha uma dor de cabeça horrível (nunca tinha uma dor tão forte, como se algo tivesse me cerrando a cabeça), não sabia o que pensar. Depois, me afastando da pessoa, passou tudo.

Uma outra vez, estava perto de uma menina adolescente de Oiá. Sempre gostei muito dessa menina, tinha algumas pessoas que estavam entrevistando ela. De repente senti uma dor, uma vontade de choro ao redor dessa menina. Ai, quando as pessoas foram embora, perguntei à mãe-de-santo o porquê dessa sensação de tristeza em volta da menina. A mãe-de-santo falou bastante da situação dessa adolescente, que chegou no terreiro praticamente maluca. Tudo isso pra dizer que as percepções das situações ou das pessoas que eu sempre tive aumentaram, até que eu acreditei em mim. E se não seguisse minhas percepções me dava mal."

Uma outra filha de Iemanjá, Maria, mulher culta que freqüenta o terreiro de vez em quanto, pois não mora na Bahia, um dia me falou que:

"Estava voltando do trabalho e ai estava sentada no onibus quando percebi uma onda de energia que rodeava as pessoas. Eu podia ver as cores em volta de algumas pessoas. Foi muito estranho. Tudo era diferente, tudo era circundado de energia e eu me sentia no ar."

Josenilda, filha de Oiá relatou uma visão que ela teve:

"Um dia, estava botando a roupa no quintal para secar, virei o olho e vejo um cavaleiro sobre um cavalo que levantou-se na minha frente. Fiquei ai sem poder me mexer, as palavras não conseguiam sair, eu estava aí parada, e o cavaleiro, outra vez, deu uma empinada com o cavalo e ai quase desmaio."

Joana, filha de Iemanjá, explica que, desde menina, tem sensações e percepções sobrenaturais e que uma vez, ainda criança, teve a sensação de sentir a respiração das plantas. Ela sempre foi muito emotiva e capaz de chorar com grande facilidade, sem mesmo saber o por quê:

"É fácil me comover e choro feito louca. Sempre senti muita vontade de andar, de conhecer... que estranho, eu não conseguia ficar parada. Agora saio com dificuldade de casa. Gosto de ficar em casa, de molhar as minhas plantas, de ler etc.

Quando vejo chegar Oxalufá9 ${ }^{22}$ - dizem ser o meu esposo -, ai vem uma coisa de dentro e choro, choro, choro... quase me acabo; me emociono muito quando vejo ele."

\footnotetext{
${ }^{91}$ Os erê são entidades infantis. Seus orixás protetores, com os quais muitas vezes são confundidos, são os gêmeos Ibejis, sincretizados com São Cosme e São Damião.

92 Oxalufã é a qualidade mais velha de Oxalá.
} 
E Josenilda, filha de Oiá, diz:

"Tem algo dentro de mim, sabe?, um fogo que sobe de dentro e aí vem uma raiva. Olhe, se não me seguro, posso até quebrar a cara do meu marido. Aquela vontade de sair, de deixar tudo, de ir, tenho que me segurar!"

Simone, filha de Iemanjá, conta que:

"No começo falavam que eu era de Oiá, mas aqui a mãe-de-santo logo viu a minha Iemanjá, ela falou que Oiá defende Iemanjá. A minha santa é muito fina, é muito sensível, ela gosta de ficar tranqüila em silencio, nada de confusão. Eu não sabia nada de candomblé, mas sempre gostei de Oiá, gosto da liberdade dela, da forca, mas na verdade no fundo, eu sou muito sensivel. Quando alguém está triste ou alegre sinto logo no peito. Quando sinto a energia de um lugar, ao contrário, é nas pernas que sinto subir e rodar a energia."

Almira, filha de Oiá, muitas vezes me falou:

"A gente sente se alguém tem energia boa ou não. A gente sente logo. Olhe, até no andar da pessoa, ou pelo tom da voz, se percebe as intenções de uma pessoa. Não é que a gente fique pensando 'é isto ou aquilo'; simplesmente, de repente, a gente sente algo: pode ser através de qualquer coisa, pode ser um quê de diferente e você saca as pessoas.

Lembro que uma vez chegou aqui uma moça, eu vi entrar primeiro uma cigana, depois reparei que a cigana era o seu espírito. Eu só via aquele cabelo e a saia que movimentava, como se dançasse."

Podemos percebemos nessas falas toda uma correspondência das sensações com o corpo. Como se a compreensão das pessoas e das coisas não fosse meramente algo mental, mas que acontece através do corpo.

Conforme os estudos de Stoller (1997), fica claro como a aproximação do orixá pode ocorrer no candomblé através de sensações e como essa religião desenvolve um processo corporal no qual o corpo conhece coisas e pessoas por meio de uma percepção alargada.

Aos poucos as pessoas são levadas a reconhecer e a acreditar nas sensações e nas emoções que o seu corpo lhes envia como mensagens, como se o processo do conhecimento não fosse apenas ligado à mente, mas tivesse uma base, um fundamento corporal, ancorado. Ressaltemos também importância de algumas partes do corpo, como a cabeça, o coração, os pés, como se fossem lugares mais apropriados para "sentir".

Uma vez, num terreiro que não o Axé Opô Afonjá, presenciei a seguinte cena: uma moça entrou na casa da mãe-de-santo e imediatamente começou a "passar mal", como se diz no candomblé. A mãe-de-santo pôs uma das mãos sobre o coração e a moça logo se acalmou. Perguntei o porquê dessa ação e a mãe-de-santo respondeu que "o orixá tem que vir no coração, é coisa demais fina". 


\section{4. $O$ caminho à iniciação: o corpo muda de forma}

Uma vez que o processo de aproximação do orixá começa a se desenvolver, toda uma série de sensações corporais ocupa um espaço maior na vida cotidiana. As filhas-de-santo falam de várias situações que as levam a freqüentar com mais intensidade o terreiro, como se algo as chamasse a participar da vida da comunidade.

Josenilda, filha de Oiá, nos conta sobre uma série de doenças e um grande desespero de de motivo econômico:

"Olhe, eu sempre trabalhei, trabalhei pra caramba! Eu e meu marido. Aquela vida do interior, a gente levantava cedo, a gente começa cedo a trabalhar no interior, e era o dia todo. Depois começou o negócio da chuva, não chovia mesmo. Aí a gente perdeu um montão de animais e também era tudo tão dificil, sabe?, não agüentei mais, sabe?. Era aquele aperto no coração, às vezes não conseguia respirar. Ai eu vi pra cá, me deram um banho, e logo, logo aquele alívio. Até ando melhor, nem dor na coluna tenho mais!"

Simone, filha de Iemanjá:

"Não sei nem como explicar! Começou aquele sofrimento, aquela depressão; às vezes sentia algo de cima que descia sobre mim e eu não conseguia quase respirar, era algo que me parava, não conseguia trabalhar, estudar. Ficava aí, parada por horas, e tudo me incomodava. Parecia que tinha alguém dentro de mim que queria gritar. E gritava o desespero que eu tinha!. Mas os outros não entendiam; eles achavam que eu estava estressada, que estava maluca, me olhavam como se eu fosse exagerada. Que nada! Estava mal e pronto. Me pegou uma depressão muito grande e o fato de estar sozinha não me ajudou!

Aí comecei a me aproximar do terreiro: tomava os meus banhos, fazia meu ossé ${ }^{93}$. Comecei a tentar me ligar mais com o meu orixá. Mas tinha momentos que não podia me mexer, era como se só as coisas negativas entrassem dentro de mim. E aí ia perto de coisa de orixá e vinha aquele alívio. Um dia em que estava mal, fui na casa de Iemanjá (no Rio Vermelho) e quando entrei chegou aquela onda e logo, logo se soltou, aquele aperto que tinha no coração, se abriu e me senti melhor e aquela noite consegui dormir.

Eu fiz um montão de coisas, fui num especialista, um psiquiatria e ele confirmou que eu não era maluca. Fui numa massagista, ela me ajudou muito. Não tinha mais tonicidade nos músculos, era toda mole; ela me disse que quando uma pessoa está muito estressada, os músculos não tem mais tonicidade. Mas, aos poucos, tomando os meus banhos, começando a ouvir as mensagens dos orixás, consegui me recuperar.

Mas muitas vezes me aconteceu de sentir uma estranha agitação, quase taquicardia, e, perto de algo ligado à religião, acontecer que algo me circundasse e me tranqüilizasse, depois, era só dormir."

Josenilda fala sobre a ajuda recebida com os banhos de folhas:

\footnotetext{
${ }^{93} \mathrm{O}$ ossé é um ritual de limpeza dos altares dos orixás, o qual acontece na primeira semana do mês, para cada orixá em seu dia da semana.
} 
"Eu estava tão mal antes da iniciação que não sei como consegui chegar até aqui. Olhe, a mãe-de-santo, depois do jogo, me deu logo um banho de folha, que a minha irmã fez pra mim, e logo senti aquele alívio, você sabe, aquele alívio. Uma coisa boa e fresca descia da cabeça até os pés.

Depois começaram os ebós e o alívio foi sempre mais forte e me sentia leve, como se tivesse feito um banho de horas. Até o corpo muda! Agora me sinto solta, meu marido me disse que pareço maior... me parece impossivel!"

Simone também relata uma mudança corporal:

"Depois de toda essa época, começou uma alegria de viver, como se por baixo das dificuldades tivesse algo que indicava uma continuação nas coisas. Por exemplo: um dia que estava trabalhando me deu uma vontade de ir no terreiro. Era a primeira quartafeira do mês, assim, o amalá era ainda mais bonito. Bom, cheguei aqui e percebi aquela energia gostosa de Xangô e sentia no peito como um sopro que me fez levantar; e até os ombros se abriram como se fossem maiores na altura e na largura.

E quando fui pra frente do peji de Xangô me pareceu que ele me sorria. Achei que eu estava completamente maluca, mas a energia dele me levantou. Até as pessoas me disseram que eu estava mais alta."

Almira, filha de Oiá:

"Ah minha filha, depois de ser iniciada comecei de novo os meus afazeres. Estava tão solta, tão leve, andava resolvia coisas, só você vendo. A minha cabeça estava leve, engordei um pouco, mas me sentia cheia, não sentia mais aquele vazio. Sabe, a gente se sente bem, com aquela confiança, até no corpo me sentia mais imponente. Você viu aquele rapaz de Oxóssi, depois de ser iniciado, tem uma outra postura, engordou; não sei, parece mais homem"

Josenilda, filha de Oiá também nos fala de uma outra relação com o corpo:

"Ah, já com os banhos de folhas eu me sentia bem melhor, aqui, o peito se abria, aquela sensação horrível de aperto sumia, aquela sensação de perda sumia, me sentia como circundada por uma bola branca e, olhe, ando bem, antes não podia mais andar.

É assim: as pessoas mudam depois da iniciação. Dizem que as pessoas de Iemanjá antes de ser iniciada viram com uma cabeçona. Eu também percebi isso com uma, aquela iaô nova. Sim, parecia que ela Tinha uma cabeçona, será pela água que tem dentro. Mas quem sabe os caminhos dos orixás? Depois mudou tudo, agora é normal."

Simone, filha de Iemanjá também:

"Olhe, a primeira vez que o orixá se manifestou firme, foi muito assustador, foi muito forte, eu fiquei muito fora do ar, fiquei muito perdida, como se algo tivesse quebrado dentro, nem sabia se os pés 'tavam no chão, mas, depois dos rituais, que sensação boa! Uma calma, uma tranqüilidade tão grande. Não sei se é a minha cabeça, mas sinto que o meu peito abriu-se, me sinto mais larga e mais alta. Até os ombros se afastaram. $O$ meu rosto mudou, eu sinto uma expressão diferente no meu rosto, mais larga.

E, olhe, não me interessa muito se engordo ou emagreço, eu sou como eu sou. Boto saia curta, saia longa, e ai me mando. Sinto os pés mais no chão, sinto uma ligação com a 
terra. Também, quer saber uma coisa? Quando fico nervosa ou ansiosa sinto algo que me pára, como se alguém dentro de mim dissesse 'deixa para lá, vai tranqüila! Não se ligue nisto!"

Até meu corpo mudou bastante, como se as costas tivessem aumentado. Me sinto mais redonda, às vezes abraçaria todo mundo.

As vezes estou angustiada, estou triste, não quero nada... aí ela vem e me alivia. É algo de doce, começa leve e depois deixa a gente mais tranqüila, mais aliviada."

Na comunidade comenta-se muito se a última chegada é desse ou daquele orixá. As velhas ebômis percebem alguma coisa do lado espiritual das pessoas até mesmo através do andar, da pele, do jeito. Fazem comentários sobre o juntó ${ }^{94}$ e sobre o jeito das pessoas. Contam-se muitas histórias, por exemplo, que as filhas de Iemanjá têm a cabeça grande porque antes da iniciação ela se enche d'água, ou que as filhas de Oiá são magras, esbeltas e muito ativas.

Normalmente, após a iniciação, as filhas-de-santo falam de alguma mudança referente à percepção das coisas e ao corpo, inclusive a postura. Josenilda, filha de Oiá, nos fala de um alívio maior e de uma nova tranqüilidade e afirma que tornou-se mais magra e que caminha mais rapidamente, enquanto a postura dos ombros ficou mais ereta, e que a expressão do rosto parecia mais madura, mais firme.

Almira, filha de Oiá nos diz da leveza e do caminhar mais veloz. Relata uma mudança no corpo ocorrida, segundo ela, depois da iniciação. Diz que o corpo ficou mais esbelto e leve, e que também a luz dos olhos mudou.

Simone, filha de Iemanjá notou uma mudança na parte superior de seu corpo, que lhe parece mais larga; e desenvolveu uma auto-aceitação que a deixa mais confiante em si mesma. $\mathrm{O}$ rosto adquiriu uma expressão mais aberta, os olhos parecem maiores e mais lúcidos; e seu andar é mais seguro e imponente do que antes.

\subsection{Os sonhos e a comunicação dos deuses}

O sonho é ponto importante no mundo das religiões místicas. Eliade (1999: 59) já tinha relatado a importância dos sonhos entre os xamã samoiedos e a riqueza dos seus conteúdos, tanto mitológica quanto religiosamente.

Bastide (1974) também nos fala da importância de uma sociologia dos sonhos e do mundo onírico nas sociedades tradicionais, esclarecendo alguns assuntos como o do papel desempenhado pelo sonho na cultura. Sustenta que, nas culturas tradicionais, o sonho não é drasticamente separado do estado de vigília, mas que as imagens noturnas são intercaladas na teia da existência e que as percepções do mundo externo se mesclam. Dessa maneira, o sonho fornecerá ao ser humano de cultura tradicional a solução de problemas que são na verdade problemas da sociedade na qual ele vive. É o sonho que irá permitir uma melhor inclusão na coletividade à qual

\footnotetext{
${ }^{94} \mathrm{O}$ juntó é o segundo orixá da pessoa. Às vezes ele fica na frente para proteger o primeiro.
} 
pertence. Como exemplo temos a grande importância dada ao sonho no candomblé, sobretudo nos momentos de reclusão iniciática, pois, através dele, os orixás se comunicam com as suas filhas ou filhos.

Assim, o sonho se reveste de uma "função social" nas culturas tradicionais. Na cultura ocidental contemporânea, pelo contrário, criou-se um corte entre o sonho e o estado de vigília, de modo que a noite e o sono se tornaram uma evasão do mundo e um refúgio a uma irrealidade fantástica de felicidade e esquecimento.

Cada tipo de sonho se dá em função da ligação do grupo social. O vínculo social é tanto mais forte quanto menor é o ambiente social de uma pessoa. É por isso que nas pequenas sociedades as tendências a comportamentos diferentes são mais reprimidas ou socialmente controladas. De tal maneira que a tese de Freud, em si, não seria nem verdadeira nem falsa; mas mais ou menos válida a depender do âmbito social. O próprio conteúdo do sonho parece depender do grau de integração com uma dada sociedade.

Sempre segundo Bastide, é possível que as imagens dos sonhos sejam oferecidas pela memória individual, mas elas são selecionadas entre aquelas do ambiente social ao qual nós estamos mais relacionados. A estrutura sociológica do sonho não é, então, um reflexo (como nas sociedades contemporâneas), mas é uma parte integrante da sociedade à qual pertence.

É sabido que no candomblé os sonhos são contados apenas à mãe-de-santo ou à mãepequena, pois são algo profundamente relacionado ao orixá e à vida espiritual da pessoa. Acredita-se que o inimigo, ao conhecer sonho de uma pessoa, poderia fazer algo para atrapalhar ou até roubar a força daquela pessoa.

Foi somente depois de muitas perguntas, e de poucas respostas, que comecei a prestar mais atenção em meus próprios sonhos e, a procurar estabeler alguma relação em sonhos de minhas informantes, as que tinham mais confiança em mim.

Pelo fato dos sonhos fazerem parte de um tipo de percepção dos sentidos (um outro sentido mais leve, mais sutil), podemos incluí-los numa tipologia segundo suas funções sociais no candomblé, desde a diagnose médica até as mensagens dos mundos dos orixás: sonhos de alerta, de proteção, premonitórios etc. Vejamos o caso de Simone, filha de Iemanjá:

"A importância dos sonhos é fundamental, são eles que nos mandam as mensagens dos orixás. Lembro claramente que a um certo ponto comecei a sonhar. Sempre sonhei muito, dizem que as filhas de Iemanjá sonham muito. Bem, para mim isso é verdade. O negócio é que, de repente, comecei a sonhar com os orixás, eu nunca tive sonhos com eles, mas de repente as mensagens foram tão claras...

Um dia que eu estava muito ansiosa e triste, nem sei porquê e continuava me perguntando o por quê dessa fadiga na minha vida e de tudo aquilo que estava passando; tive uma resposta na mesma noite. Naquela época morava num morro, perto da Boca do Rio. No sonho estava descendo a ladeira quando vi uma mulher vestida de vermelho que começava a rodar sobre si mesma e, rodando, saía vento através do vestido dela, que era vermelho. De repente parou e dizia: 'Não se preocupe, você irá encontrar as respostas. Fique tranqüila, não seja triste, tudo será explicado'. Acordei tão agitada! Quem era aquela mulher loira, vestida de vento? 
Também, cada vez que falava com a mãe-de-santo, ela sempre dava risada e dizia que 'as filhas de Iemanjá sonham muito, não tem jeito', e que eu tinha que acreditar nos meus sonhos, pois encontraria a resposta neles. Depois, reparei que nos momentos mais dramáticos sonhava muito; e com os orixás que me mostravam as respostas.

Não posso contar mais, porque você sabe como é no candomblé, mas tive tantos sonhos... até sobre as pessoas, aquelas em que eu podia ter confiança e aquelas em que não podia ter confiança.

Sobre meu marido, ligado ele também ao candomblé, poderia escrever um livro! Até as nação na qual foi raspada a mãe dele eu soube nos sonhos! A nossa foi uma história complicada, mas deu certo, Eh... Bom este, acho que eu posso, não é nada...- Simone ficou parada um momento, com os olhos fechados, como se concentrasse; e continuou:

"Quando conheci meu marido, não sabia nada dele, nem de orixá. Uma noite sonhei que eu acordava perto dele e eu estava recoberta de chagas e me coçava em continuação. Aí meu marido me dizia: ' não se preocupe que eu vou cuidar de você'; passava algo sobre mim e tudo sumia. Eu juro, não sabia nada de orixás, nem que ele é filho de Omulu. Veio no sonho! Ainda me arrepio pensando naquele sonho.

Numa outra época na qual meu pai estava muito mal, ele se foi depois de uma semana, me parece. De noite sonhei com algo rodante que saia como de um buraco e uma voz me falou pr' eu me preparar que meu pai ia embora em pouco tempo.

São coisas estranhas porque...quem sabe... Eu fico me arrepiando. Bem, um dia...mas depois de um tempo eu a vi, a minha Iemanjá, ela era toda vestida de verde e azul com longos cabelos e eu lhe oferecia algo numa bandeja de prata. Saia do mar, não posso errar, eu também estava na praia.

Acordei gostando de ter visto a minha Iemanjá. São mensagens profundos que tocam a gente. Ela veio de verdade pra me dizer algo. Pena é que sempre ando rápida e às vezes não dou a importância que merecem esses sonhos. Mas você sabe como é a vida, é tão corrida."

Uma filha de Oxum, Valdira, muitas vezes falou dos sonhos que teve antes de ser iniciada:

"Olhe eu tinha visões que me assustavam, mas também sonhava muito com sombras e como fantasmas que me perseguiam. Acordava como uma criança gritando e angustiada. Depois de ter feito alguns trabalhos para os meus antepassados não tive mais esse tipo de assombração. Graças a deus! O meu pai-de-santo acertou mesmo! Mas só com a iniciação que verdadeiramente fiquei tranqüila. A gente passa cada coisa! E os outros de fora acham a gente maluca, mas candomblé não é para loucos não, é questão de mediunidade, de ser da coisa, de sentir que algo existe ao nosso redor, a gente sente, mas não pode falar.

As pessoas estão acostumadas a não perceber nada, ficam aí achando que sabem tudo, mas quando sofrem vêm aqui a procurar o terreiro e aí começam a se abrir a um outro lado da vida, aos orixás.

Tive uma época que eu só andava dormindo e sonhando, mas não sabia mais se na realidade era o meu sonho ou vice-versa. Era muito dificil para mim ficar acordada, 
estava tonta o tempo todo, mas de noite tinha, continuamente, sonhos. Até de dia ia caindo de sono e sonhando. Um belo dia tive um sonho lindo, um amigo meu me dava uma criança loira e gordinha; ao redor dela tinha um arco-íris de várias cores, mas sempre com uma tendência ao azul e verde. Bem, tinha um arco-íris ao seu redor e ele parecia suspenso na luz."

Ao longo da pesquisa, percebemos sempre mais que os sonhos são outros modos somáticos de atenção. No estado de sono, segundo essas falas, a alma tem uma possibilidade maior de captar e de viajar e por isso podemos encarar o sonho como uma forma superior de captação.

E, continuando com os depoimentos, Josenilda, filha de Oiá:

"As pessoas não gostam de quem sonha muito, você sabe como é, quem sonha sabe muito! E às vezes a gente não quer saber! Este mundo é tão misterioso! A gente não sabe nada, às vezes você pensa de ter encontrado algo de bom e, de repente, muda tudo!

Olhe, os orixás são muito potentes, eles ajudam a gente, você sabe que depois que a gente veio para cá, Oiá quis vir também. Você sabia disso? Minha avó sempre falava isso. Então, é com os sonhos que eles nos falam. Nem sempre tem que dizer seus sonhos ás pessoas, às vezes é uma mensagem só pra você e você mesma é que deve interpretar. Às vezes você deve fazer uma oferenda e o orixá fala direto pra você. Olhe, mais passa o tempo, mais você tem que saber lidar com as coisas e perceber os sentidos dos sonhos, 'ta? Também, nem todos os sonhos são recados, às vezes a gente está agitada e então sonha algo que não é uma mensagem, que simplesmente vem dos nervos!

Um dia me deu uma vontade de fazer um presente a ela, a minha Oiá, tive um sonho que eu estava oferecendo algo pra ela. Ela era muito bonita, toda de vermelho e ar, parecia mesmo que o ar tivesse tomado a forma dela. Bem, comprei um belo prato de bairro, arrumei os acarajés e o acaçá e ofereci no lugar que ela gosta."

Conforme Bastide (1974), o sonho, a vida noturna, é parte integrante do ser humano e existindo uma unidade real entre suas duas metades - a espiritual e a do dia-a-dia - , como entre o mundo dos mitos e do sagrado, ao qual o sonho está relacionado, e o mundo social no qual o ser humano vive no estado de vigília. O sonho, portanto, é uma mensagem das divindades e deve ser interpretado, submetido aos especialistas religiosos, para que se conheça seu sentido. Se, por exemplo, a mensagem é uma profecia de calamidade, providencia-se uma mudança de conduta e se fazem oferendas e sacrifícios para as divindades para evitá-la.

As falas relatam também a riqueza do simbolismo e das cores desses sonhos, que são entendidos pelos fiéis como mensagens dos orixás. Percebe-se também que ao longo do processo ritual as fiéis são levadas a acreditar sempre mais nos próprios sonhos e a desenvolver uma ligação mais individual com seu orixá, a ponto de fazerem oferendas e dialogar com ele, sem a mediação da mãe-de-santo. 


\subsection{A construção da pessoa e a dinâmica do equilíbrio}

Analisando as falas das pessoas entrevistadas, e tendo como base a minha experiência na comunidade, entendo que a pessoa no candomblé está formada por um conjunto de partes em relação entre si.

Tendo como base os trabalhos de Abimbola (1973), Bastide (1973), J. Elbein dos Santos (1973) e Verger (1973), sabe-se que a construção da pessoa para os iorubás é um processo de comunicação das múltiplas partes da identidade pessoal ao longo da socialização. A identidade, que é um elemento da realidade subjetiva, se encontra em relação dialética com a sociedade e, assim, existe uma interação entre a estrutura social, a história, o organismo e a consciência individual.

Conforme Bastide,

"A unidade da pessoa nos é dada em termos de unidade formal ou estrutural nos itinerários que estão em tensão" (Bastide, 1981: 41).

A pessoa é, portanto, um sistema dinâmico e plural, apreendido no cotidiano dos terreiros e mantido unido através das práticas rituais que permitem a integração dos contrários.

Conforme Prandi,

"O eu é sagrado no candomblé. Ele não é somente parte do orixá geral (Augras, 1983). Cada pessoa tem um deus particular, que deve ser assentado num seu altar privativo, que tem um nome que é só dele. (...) O deus de uma pessoa importante na religião pode ser herdado e continuará a merecer culto, mas ainda assim não substituirá o orixá pessoal do herdeiro" (Prandi, 1991a: 123).

Mas além do deus particular de cada pessoa há uma pluralidade de divindades e de outras partes espirituais como o egum, o antepassado, o Exu pessoal e o erê, a parte criança do orixá, as quais devem estar de acordo e em harmonia. Assim, se consideramos essa representação como uma espécie de modelo da personalidade, a pluralidade e a existência dos conflitos aparecem como uma característica marcante do eu e podemos sublinhar que a iniciação é um sistema que integra as divindades pessoais em um sistema mais harmônico. As práticas rituais se repetem, de fato, ao longo do percurso dos fiéis e numa sucessão de obrigações, realizadas após um ano, três, sete, quatorze e vinte e um anos.

Mas o enredo ou carrego - como é chamado no candomblé a pluralidade das divindades - nunca é estático e sim dinâmico e criativo, construindo a história da identidade do fiel no candomblé (Augras, 1988). Assim a realidade individual existe no conjunto das ligações que unem o ser humano aos diversos princípios constitutivos do cosmo e das relações sociais.

A pessoa é formada por várias forças espirituais que, conforme Verger (1973), são o emi (a alma, o sopro vital); o ojiji (a sombra); o ori (a individualidade, a cabeça); o egum (o ancestral); e o erê (que seria uma qualidade infantil do orixá). Quem organiza todo o enredo é Exu, deus da comunicação e das encruzilhadas. (Bastide, 1978: 170). A esse respeito, vejamos o 
que nos relata a ebômi Elvira, filha de Oxalá, de 72 anos (e 60 anos de santo), numa entrevista feita na sua casa:

"E então vamos, você quer saber como é uma pessoa?" - ebômi Elvira nos olhava e, sentada em sua cadeira preferida, dentro da sala-cozinha, e olhando para a porta de entrada, começou a nos falar, com aquele seu ar meio irônico e meio plácido.

"Dizem, digo dizem, porque nunca se sabe aqui no candomblé, aquilo que é e aquilo que não é. Então, se temos as pernas deve ter um porquê, todo esse trabalho que é o candomblé serve para ligar o ser humano à natureza, assim as pernas estão sempre em ligação com a terra, onde moram os ancestrais; sem eles, nada poderíamos fazer. A gente tem que saber a origem da nossa família porque isso nos sustenta. - Ao dizer isso, ela se debruçava para a terra com as mãos, como que para tocá-la, e fazia uma careta, como para manifestar a importância daquilo que estava dizendo. - Vocês já viram os egunguns, então vocês sabem como chegam e a voz que eles têm, eu já fui curada por eles, quando era criança. Eu tinha uns seis anos, fiquei muito doente, muito doente mesmo, ai meu pai, que sabia das coisas, me levou na ilha e aí, um dos babá mais importantes cuidou de mim, ainda lembro as cores dele e logo, logo disse que eu deveria cuidar do orixá; mas essa é uma outra história.... - ela nos disse sorrindo, como se visse algo na sua frente Depois, temos que nos ligar ao céu, o mundo dos orixás - nesse ponto, ela levantou e direcionou os braços para ao céu —, mas a gente não tem somente um orixá; temos vários que podem nos ajudar em vários momentos da nossa vida, temos sempre que nos reverenciai-los, mas é assim eles estão aí para nos ajudar. Mas aqui no Axé é somente um que desce na cabeça, não é possivel que baixem mais, a gente enlouqueceria. O certo é fazer todas as nossas obrigações no momento certo e agradar também sempre ele, o homem $^{95}$, o compadre.

Temos que ter muito cuidado com orixá, orixá é coisa viva, não é distante, ele é vivo em nós. Existem tantos caminhos para que ele se mostre. Ele é a própria vida, por isso tem que ter respeito e veneração.

Dizem que Olodumare um belo dia chamou por Obatalá e lhe disse que construisse a cabeça dos homens. Depois, Olodumare soprou o princípio vital, o emi no ser humano e ele respirou. Mas a gente possui também a nossa materialidade, o corpo (ara).

O emi está ligado à sombra das pessoas, quando não temos mais o emi a gente morre.

O ori para nós é o orixá; somos nós, é a nossa inteligência, o nosso ser. O ori é a cabeça que é a dona de todas as coisas. A cabeça é um mundo, através dela vem os movimentos, os espiritos, por isso a gente tem que fazer o bori. Quando tudo está em harmonia, é uma beleza, se percebe logo quando uma pessoa está bem, satisfez seu orixá. A gente vê, percebe. Você viu aquela senhora que entrou outro dia, aquela estava muito mal, muito mal mesmo, e...depois todo mundo vem para cá. É isso!

Mas para ter forças e equilibrio temos que trabalhar, nada é de graça, temos que trabalhar e satisfazer primeiro o orixá. Depois da iniciação e das obrigações a gente

${ }^{95}$ Entenda-se aqui com a palavra o homem ou o compadre Exu (Bastide, 1978: 170). 
muda, muda o corpo; você não viu aquele rapaz de Oxóssi ${ }^{96}$, tem um outro corpo, até a cara mudou.

Então lhe perguntei um pouco mais sobre $\operatorname{Exu}^{97}$ e a sua função:

"Exu, não tem nada de mal, não é essa coisa do católico, ele é o mensageiro, é ele que abre e fecha as portas, que bota em comunicação. Então é ele quem governa a casa, e a nossa casa é o nosso corpo, ele é responsável por tudo. Não viu que é o primeiro a ser homenageado? Então é o motor de tudo; sem Exu, minha filha, não tem nada. E nada de malvadeza, as pessoas não se comportam e, depois, a culpa é dele... que nada! Os homens são descarados, descarados e basta" - concluiu nossa informante, com uma cara de satisfação.

Mãe Maria, filha de Oxumarê, 41 anos de santo ${ }^{98}$

"A minha é uma história bem comprida, você tem tempo para ouvir? - Ela nos perguntou, bem sentada num sofá, após ter botado cinco dos seus sobrinhos no outro quarto.- Tinha uma irmã que queria ser empregada, então deixei um trabalho, que tinha encontrado, pra ela. Mas ela começou a ficar doente; lhe fizeram um feitiço. O cabelo, de duro, virou solto; ela tomava muito, muito, remédio.

Ela teve queimaduras nas mãos e nos pés. Com certeza era feitiço. Feitiço foi feito - nos fala, se aproximando, com os olhos bem abertos.-Então foram para a ilha para falar com um Baba ${ }^{99}$ verdadeiro, lá no bairro Vermelho, em Amoreira. Um homem apareceu, querendo se casar com a irmã. Assim, foram consultar o Babá.

O ojé chamou um egum, que nos falou do feitiço e de quem o fez. O egum falou de um remédio e que a familia tinha raiz africana e que a qualquer tempo alguma pessoa poderia ser raspada.

Tive um filho e lá para 28, 30 anos fiquei na cama. O pescoço estava torto. O corpo todo encheu e as pernas, muita dor no pulmão. Fiz um bocado de coisas até raio-x, que não dava em nada.

Minha irmã, que entendia mais do que eu, me pediu para ir na casa de um pai-de-santo para olhar. Eu não queria ir, mas depois fui. Ele falou para fazer um ebó forte, pois eu tinha um egum perto. Precisava também de um bori e disse que o santo queria ser feito.

Minha mãe falou que bancava para fazer o santo. Eu fui falar com um padre italiano, estava com medo. Entrei no 14 de agosto 1960. Apareceu Oxumarê que foi raspado. Ela ainda estava doente e, então, Oiá falou pra procurar também um médico.

Ai depois de um tempo ela mesma resolveu arriar uma comida para o santo, para Oxumarê na praia e ela logo, logo, ficou bem. Oxumarê tem um Exu chamado Nego d' Água, 'cês sabem tem um bocado de Exu. Ele mandou comprar as coisas para a oferenda

\footnotetext{
${ }^{96}$ A informante está falando de um rapaz de Oxóssi recém-iniciado.

${ }^{97}$ Sobre Exu, suas atribuições no panteão iorubá e mudanças que seu culto sofreu no Brasil, veja-se Trindade (1985) e Prandi (2001 b).

${ }^{98}$ Tentarei escrever do modo como essa senhora fala, às vezes com palavras usadas pelos antigos, coisa bem comum na Liberdade, o bairro onde ela mora.

${ }^{99}$ Quando se fala de Babá, fala-se do terreiro dos eguns da Ilha de Itaparica (ver Braga, 1992; dos Santos, 1977).
} 
e botei na praia perto da onda, mas apareceu o Nego d'Água que falou que ele queria a oferenda na água.

Ai tudo melhorou" - Acabou de contar, deixando o olhar parado e cruzando os braços no peito.

Ebômi Cleusa, filha de Oxum e Oxalá, 27 anos de santo, nos diz:

"Eu tive sempre, desde menina, muita visões. Eu me lembro de todas. Há sete anos tive artrite e fiquei sem poder me mexer. Então a minha mãe me dava banho às três, quatro horas da tarde. Quando eram dezoito horas vi sair da parede uma mulher que ficava no quarto e esperava. E eu gritava:' estou vendo uma mulher, estou vendo!' E ai continuava com febre e artrite, assim foi no espiritismo. Eu, naquela época, morava em Niterói (RJ) e tinha dois tios no candomblé, um de Oxóssi - que tinha também um caboclo, Jubiabá e outro de Ogum. Oxóssi pegou o meu tio e deixou um recado, dizendo que ele tinha uma sobrinha que estava doente do outro lado do mar e que ele fosse lá. Assim, o meu tio ligou para o meu pai e foi me visitar. Logo, logo Oxóssi pegou ele e tirou um ebó porque estava com um egum perto.

Aos dezesseis anos ela ia com uma senhora de Nanã para ver candomblé, ela não tinha muito interesse, só espiava. E tudo andava indo sempre espiando, mas nunca entrando em fundamento. Ela conheceu muitas pessoas, quando eles queriam falar entre si, sem os outros entenderem, eles cantam. Conheci João da Goméia, ele tocava muito jeje. Uma vez os orixás eram muito diferentes, cantavam cantigas de fundamento.

O pai morreu e o egum dele começou a persegui-la, ela teve problemas mentais. Ela já tinha conhecido o Opô Afonjá do Rio (de Janeiro). Um belo dia meu pai-de-santo foi ao Rio para fazer uma obrigação e, por acaso, eu o conheci, marcamos um jogo e logo se viu que era um egum que me perseguia. Assim vim para cá. Fiz uma obrigação na ilha e depois pro santo."

Percebemos, claramente, que os espíritos têm preferência por algumas partes específicas do corpo (Abimbola, 1973: 85), por exemplo, no coração, mora o emi; já na cabeça, existe o ori e, finalmente, o essé, nas pernas, que são consideradas uma parte vital da personalidade humana, tanto física quanto espiritualmente. Essé, para os iorubás, é o símbolo do poder e da atividade. O ori e o essé devem sempre estar em comunicação para atuarem bem na realidade, e são ligados pela coluna vertebral, que transporta as mensagens.

Todas essas partes do ser humano (seja enquanto carne ou espírito) são colocadas em comunicação através da ação de Exu que, como diz Bastide,

"É ele, e somente ele, que representa o principio da dialética e da intercomunicação.

Respeitando a diversidade ou multiplicidade do real, é ele que oferece a base da unidade do próprio real" (Bastide, 1978: 197).

Então, a chave da realidade individual está no conjunto das relações, que ligam o ser humano aos diversos princípios constitutivos do cosmo, e das relações sociais, e os elementos da pessoa ou indivíduo. Nas falas das últimas entrevistadas é possível perceber o quanto é importante a ligação com o ancestral, como primeiro passo. É à terra que as fiéis têm que se voltar logo no começo do processo ritual. Existem, então, toda uma série de rituais que 
evidenciam e dão forças a cada parte do corpo, até chegar à iniciação, numa continua alternância de equilíbrio e desequilíbrio e de reequilíbrio das forças.

A primeira coisa que uma (ou um) fiel recebe, ao se aproximar do candomblé, é sua conta lavada, isto é, ela recebe uma conta da cor da divindade a qual pertence: branca para Oxalá; amarela para Oxum; verde ou branca transparente para Iemanjá; vermelha para Oiá etc. Mas essa conta recebe valor somente se for lavada com um misto de folhas ligadas à divindade dona da cabeça e, depois, submetida a outra lavagem, dessa vez com sabão da Costa — que vem da costa africana - é sabão preto e mole, com um cheiro forte. Após essa lavagem, a conta é posta no pescoço da(o) nova(o) fiel ou pela mãe-de-santo ou por uma outra sacerdotisa anciã, a fim de dar maior axé ${ }^{100}$.

Outro ritual de grande importância é a lavagem da cabeça, porque nela reside o orixá. Ela é lavada com folhas especiais, para dar forca ao ori, e, depois, recebe uma outra quantidade dessas folhas, que devem permanecer na cabeça somente por uma noite; e, na manhã seguinte, vem alguém para retirá-las. Esse ritual é acompanhado com cantos e preces, na frente do peji de Xangôo ${ }^{101}$.

Na manhã do dia seguinte, a fiel recebe um banho de folhas em todo o corpo, ligando-se assim ao deus, ao ser humano (a mãe-de-santo) e ao seu colar de contas (elequê). Esse ritual prevê, portanto, uma aproximação com o orixá mas não tem tabus especiais.

Já o bori — que significa "dar de comer à cabeça" — seria mais profundo (Querino, 1938; Verger, 1981; de Azevedo Santos, 1993), envolvendo um grau maior de comprometimento iniciático. Existem dois tipos de bori, o de água (o frio) e o quente (com sangue). O primeiro consiste em oferecer à cabeça um obi e uma quartinha d'água. Usualmente, ocorre na presença de poucas pessoas e, conforme as entrevista, serve para dar um equilíbrio à cabeça, para resfriá-la dos pensamentos. O de sangue é muito mais rico; nele é oferecido à cabeça sangue de pombo sacrificado. Não descrevemos o tal ritual porque isso já foi feito várias vezes, mas sublinhamos as partes do corpo que recebem o sangue e o obi mastigado, assim como a gestualidade dos participantes: a fiel é posicionada sobre uma esteira com as mãos aberta para o alto e as oferendas são feitas às devidas partes do corpo, principalmente à cabeça, aos ombros. ao peito e aos pés.

O corpo todo é colocado como para receber; ele não tem que fazer nada, tem que ser passivo. A cabeça recebe o obi e o sangue do sacrifício na parte frontal, atrás e de lado (na altura das têmporas) e no centro. O resto do corpo recebe em suas polaridades: os dois ombros, os dois polegares, o da direita é ligado ao ancestral masculino, o da esquerda está ligado ao ancestral feminino e as mãos. Depois, a cabeça é recoberta com um ojá ${ }^{102}$ e a fiel deve repousar até a manhã seguinte, recebendo, normalmente, mensagens dos orixás por meio dos sonhos.

\footnotetext{
100 Antigamente se dava importância maior a esse ritual. As velhas sacerdotisas ressaltam sua importância (ver Querino, 1938: 82-83).

${ }^{101} \mathrm{Na}$ ocasião em que pude presenciar, estavam presentes, além da devota, somente a mãe-de-santo e a mãe-pequena da recém-chegada.

${ }^{102} \mathrm{O}$ ojá é um lenço estreito e comprido usado na cabeça como torço ou em forma de laço no peito.
} 
As súplicas e orações feitas pela mãe-de-santo são executadas com o seguinte movimento: juntando-se as mãos na altura do peito, as abre para o fora, alargando os braços e juntando as mãos novamente sobre o coração.

Usualmente não acontecem incorporações, mas uma ligação mais forte entre o deus, os ancestrais, os membros presentes do candomblé e a pessoa que se submete ao bori.

Segundo Mãe Stella, o bori é uma cerimônia de grande significado litúrgico: é a adoração da cabeça, realizadas pelo conjunto de oferendas, cânticos e louvações. A participação das filhas ou filhos-de-santo é essencial, já que se estabelece a comunhão com a cabeça do "outro" e há troca de axé. Quanto mais pessoas houver para louvação da cabeça, para comer a comida do bori, tanto melhor (Azevedo Santos, 1973: 62).

Depois do bori, a fiel torna-se abiã, quer dizer, uma aprendiz com poucas responsabilidade, mas com a obrigação de apreender e ajudar na vida cotidiana do terreiro. Tem obrigação de passar se debruçando e de dar o dobale na frente dos orixás, da Mãe-de-santo e dos mais velhos. Deve começar também toda uma aprendizagem fundamentada sobre o corpo e as suas posturas.

Se o santo está "pedindo mais" à mãe-de-santo - isto é muito freqüente nos terreiros tradicionais da Bahia —, é proposto um assentamento, ou seja, um ritual mais elaborado e significativo no qual se prevê a reclusão da fiel por uma semana.

No assentamento realiza-se a sacralização do altar particular do orixá da pessoa com a pedra, o otá, ou os ferros que representam o orixá, os quais são consagrados juntamente com a cabeça da pessoa. Não se trata da feitura completa, mas é algo que prepara a fiel para o próximo passo - que será o da feitura - e que ativa seu lado espiritual. Ao longo da reclusão, a fiel será visitada somente pela mãe-de-santo e pela mãe-pequena, pois não pode ter relacionamento nenhum com os de fora; e essas duas serão informadas dos sonhos e das sensações da préiniciada. A atmosfera criada é de grande proteção e de máxima atenção, no que se refere ao mundo espiritual e aos sonhos. Todos esses rituais são antecedidos por banhos de limpezas e ebó $^{103}$ e não prevêem nem o transe nem as danças rituais.

É fundamental ter um bom relacionamento com a mãe pequena (ou mãe criadeira), pois é ela que se ocupa do "crescimento" da filha-de-santo e que a seguirá por todo o caminho religioso. Criam-se, assim, laços muito estritos entre ambas a ponto dela também receber avisos, sensações e sonhos sobre a filha espiritual.

É bem verdade que há toda uma aprendizagem que começa desde a primeira entrada no terreiro e as velhas ebômi sabem, por antecedência, se tal ou tal abiã irá rodar ou não. Muitas vezes presenciamos apostas sobre a mediunidade de algumas pessoas. Existe todo um vocabulário secreto, usado pelas velhas, a fim de falarem entre si e não serem compreendidas pelos de fora.

\footnotetext{
${ }^{103}$ O ebó é um sacrifício ritual, uma oferenda. Pode ser uma oferenda votiva ou um sacrifício de limpeza ou descarrego. Neste caso serve para transferir a alimentos e a animais sacrificados certos males que estão no corpo da pessoa (Prandi, 1991a: 246).
} 
Nesse rituais até chegar o momento do assentamento - que propulsiona e faz explodir a mediunidade - a fiel começa-se a incorporar uma diferente postura, que transforma a estrutura de seu corpo, cujas posições tornam-se mais equilibradas e simétricas.

Até ocorrerem as primeiras manifestações do orixá o corpo torna-se mais mole, mais fraco (quanto a tonicidade muscular), fato que foi nos foi explicado por uma ebômi:

"O corpo deve estar preparado a receber a força do orixá, como faz uma divindade pra entrar no corpo de uma pessoa rígida? É impossivel.

O corpo sabe o que tem que acontecer então se prepara. O corpo todo se prepara, não pense que é somente a cabeça... de jeito nenhum! Como faz Iemanjá pra dançar se as pessoas têm aqueles braços rígidos, ou, como fazer um jincá bem feito se os ombros não estão bem soltos?

Eh... candomblé é muita coisa, é muita coisa mesmo.

Tem um conto que diz que uma vez a cabeça vangloriava-se de ser a parte mais importante do corpo e menosprezava as outras partes. Assim, todo mundo estava sempre zangado. Um belo dia o ânus decidiu de não trabalhar mais e mostrar seu papel ao corpo. O pobre corpinho começou a passar mal e a cabeça estava sempre pior, com dores horriveis. Depois de um tempo, todos os órgãos estavam doentes e pediam ao ânus que voltasse a trabalhar. Ele voltou, sendo demonstrado à cabeça que todas as partes do corpo são importantes e que devem trabalhar juntos."

\subsection{O processo orgânico}

Diante do exposto até este momento, percebemos que o corpo é fundamental para o candomblé, que poderia muito bem ser chamado de religião corporal. As emoções religiosas são intensamente vividas pelo e através do corpo. Um corpo inicialmente assustado, sofrido, mas que se torna companheiro e que protege. Conforme nos contaram as entrevistadas, e segundo nosso próprio acompanhamento, aparentemente, a desordem inicial propulsiona um processo orgânico que se desenvolve ao longo do percurso ritual, de acordo com as possibilidades pessoais das fiéis.

Existem alguns pontos do corpo que são importantes e que têm que ser unidos entre si o ori (a cabeça); o emi (o coração); e os essé (as pernas) - , pois juntas, e em plena comunicação, essas três partes conduzirão as pessoas, tanto física, quanto espiritualmente, a uma vida bem direcionada, uma vez que são o fundamento da pessoa. Outros pontos importantes são as articulações, muitas vezes, nas conversas no terreiro nos falaram das articulações, em especial, as do joelho. A força do orixá da cabeça sempre esteve latente em algumas partes do corpo, ou no corpo inteiro, mas, segundo o percurso desenvolvido, chega a se fixar na cabeça e a melhor direcionar a fiel.

O processo orgânico levado a uma situação de estresse ou de dor conduz a uma comunicação com o "antigo" — o fundamento da pessoa, o que uma vez ouvimos ser chamado de 
guiné $^{104}$, o orixá - e, através de alguns rituais, se ativam os sentidos, ampliando e intensificando as percepções do mundo sensível e supersensível. Tal ampliação leva a pessoa a um outro entendimento das pessoas e da vida.

Os "modos somáticos de atenção" de Csordas (1993) servem para dar uma segurança às pessoas e para fazer com que aprendamos a olhar/encarar mais profundamente as pessoas e as situações. A fiel não é deixada só em seu drama; ela é amparada para uma comunidade que teve a mesma experiência e que pode fornecer, em primeiro lugar, rituais de ajuda até que a pessoa possa Ter de volta um novo equilíbrio e, em segundo, ensiná-la a ajudar outros. O sofrimento, então, torna-se base da própria experiência e lhe dá valor, o que faz com que a fiel adquira a possibilidade de se modificar e de obter outra visão, e postura, de sua vida.

Existe um valor, que não é moral, e sim da própria experiência nas coisas feitas, nos rituais e na compreensão da realidade e, freqüentemente, ele é alcançado com dificuldade e dor. Porque, embora pertencendo à comunidade, a experiência da pessoa é única; como única é a sua formação interna e a sua individualização.

O candomblé é algo profundamente difícil de ser compreendido porque o conhecimento se dá através da linguagem não verbal e da experiência encarnada que assume valor. Quando alguém passa a fazer parte de uma comunidade não se pode mais fazer perguntas; aprende-se com o olhar e por meio da prática do trabalho. Aprende-se com o silêncio e com a repetição dos gestos, dos cantos etc. Repetição que não é algo de frio e mecânico, mas é a encarnação da experiência diretamente do trabalho para os deuses. É uma cultura do silêncio e do olhar, assim como aprendiam os sábios antigos; as palavras voam, as experiências se fixam nos corpos, nos próprios corpos. Assim, aprende-se valorizar as pessoas, os animais, as plantas, enfim, os deuses que ajudam na vida que é, geralmente, difícil e perigosa.

Para um ocidental a aprendizagem acontece por meio de uma seqüência lógica de causas e efeitos, conseguida através de um discurso racional, no qual o lado emotivo deve ser constantemente controlado e relegado a uma outra esfera. No candomblé, ao contrário, aprendese a lidar com ele; o lado emotivo faz parte da natureza humana e deve participar da vida, mesmo na aprendizagem e na experiência.

A existência do ser humano é difícil e sofrida e vai se harmonizando na medida do acúmulo de experiência (conhecimento). Esse conhecimento ocorre com a experiência e a continuação da tradição que oferece trilha a serem seguidas.

A filosofia do candomblé percebe a vida como um todo; como uma corrente, cada fiel (cada objeto, cada planta) está ligado ao outro e, portanto, cada um tem que participar como pode no seu lugar. Como ressalta Giselle Cossard-Binon ${ }^{105}$,

"O candomblé é uma corrente. Todos os rituais têm que ser seguidos porque é uma corrente que leva a ser mais firmemente ligada aos próprios orixás".

\footnotetext{
${ }^{104}$ Essa noção de guiné me foi passada por uma informante de Cachoeira, no Recôncavo baiano.

${ }^{105}$ Entrevista feita em janeiro de 2001 na Fundação Pierre Verger, por ocasião de uma sua visita a Salvador.
} 
Como todas as religiões iniciáticas, existe no candomblé um esforço para conduzir o fiel a uma presença no mundo. Presença que não é dada a priori, mas alcançada ao longo do processo. A proposta do candomblé é a construção da fiel, tanto espiritual e quanto psicologicamente, seguindo, lentamente, cada etapa.

Em todo o compromisso do fiel com o candomblé existe o esforço a fim de reconhecer e recompor as próprias partes num todo; a ser presente à própria vida; a experimentá-la completamente; a agir no mundo. E isso é atingido através de uma longa aprendizagem que coloca o corpo e as suas experiências em primeiro lugar. Ao centro, o valor supremo, a vida, que deve ser vivida aqui e agora; e do corpo, que é o altar do ser humano. 


\section{Capítulo 5:}

\section{A INICIAÇÃo}

\subsection{O processo da iniciação}

A iniciação é um processo que leva o fiel às origens, ao começo, à antiga arché dos gregos. Conforme Monique Augras,

"O saber iniciático é o saber das origens, que não se assimila apenas, mas se vive. Tamanha é a transformação do iniciado, que recebe novo nome: tornou-se outro. A iniciação, o recomeço é, portanto, metamorfose" (Augras, 1983: 17).

Tal processo é uns dos tabus do candomblé, ninguém fala sobre isso e qualquer pergunta recebe em troca palavras "disfarçadas". Trata-se de receber uma revelação secreta sobre a tradição esotérica que a inicianda foi chamada a perpetuar. Mas, no fundo, conforme Verger (1981: 44),

"Ao iniciando não é comunicado um conhecimento esotérico, ou algo do gênero, e ele, a seguir, não é introduzido nos mistérios da religião. Ele, na verdade, torna-se, com o correr do tempo, portador de um saber secreto, que não pode profanar, mas o acúmulo de conhecimentos corresponde a um crescimento individual, gradativo, dentro do culto, $e$ decorre de um processo de aprendizado normal."

Esse conhecimento nos é passado, de alguma maneira, por meio da compreensão corporal.

Assim, ao invés, de chamar o ritual de iniciação, seria mais adequado o uso da expressão "ritos de passagem". (Van Gennep, 1909) De fato podem ser observadas a sucessão de três fases distintas: 1) a da separação — o indivíduo é afastado por um período do seu grupo; 2) margem - 
um período intermédio, liminar; 3) agregação — a volta à sociedade, tendo alcançado um novo estado.

A terminologia do candomblé utiliza o termo feitura ou fazer a cabeça, sendo essa última a parte do corpo mais importante do iniciando.

Um dos objetivo da iniciação é a transformação dos iniciados, tanto em seu aspecto interno, dando força e poder, quanto nas relações sociais (entrosando-o numa nova família espiritual que tem laços entre si mais fortes do que a própria família.) Outro objetivo é o de preparar o corpo para receber uma força potente, a do orixá.

\subsection{O desenvolvimento da feitura}

Partindo da concepção de que a pessoa para o candomblé é múltipla e plurifacetada, no desenrolar-se da feitura se conhecem e se dão força a todas essas partes e também ao orixá dono da cabeça. Essas forças podem ter influência negativa sobre a pessoa e podem perturbar seu equilíbrio psíquico e físico, como possuir o corpo do fiel sob uma forma ainda selvagem (no assim chamado santo bruto); fazer aparecerem doenças; causarem vários tipos de transtorno e problemas (afetivos, econômicos etc.)

Assim que se verifica que o santo chama, através do jogo de búzios, começam os preparativos. Com a iniciação, os laços entre a fiel e o orixá tornam-se mais forte e a manifestação do deus, mais controlada. No entanto, para que isso aconteça, haverá um treinamento: a fiel será observada para perceber a sua composição espiritual a fim de poder moldá-la segundo os padrões estabelecidos pela tradição.

$\mathrm{Na}$ formação do abiã, a "transmissão do saber iniciático faz-se por meio do canto, dos gestos, da dança, da percussão dos instrumentos, do ritmo, da entonação de certas palavras, da emoção que o som exprime" (Augras, 1983: 68). Todos estes aspectos aglomeram uma forma sistemática de moldar o desempenho do iniciando como futuro sacerdote.

Consegue-se obter o controle, pois sejam as influências negativas, sejam os orixá, tornam-se protetores.

Já estão disponíveis na literatura sobre o candomblé — Verger (1981: 36); Beniste (1997: 268); Vallado (1999: 87), entre outros — algumas descrições da feitura.

O período todo da iniciação tem uma duração de dois até três meses. As iniciandas chegam ao terreiro usualmente cerca de duas semanas antes da reclusão, porém, ninguém conhece a data exata do começo do ritual. No Axé tudo isso é ainda mantido segredo.

Geralmente chegam de noitinha, carregadas de sacolas e com grandes esteira debaixo dos braços, e com isso iniciam a lenta separação com o mundo de fora. A partir deste momento, a pessoa passa a ser assistida pela mãe pequena ou mãe criadeira ou, ainda, ajibonã, que tem a incumbência de acudir e assistir a inicianda. Os primeiros dias são de descanso, com uma alimentação leve, depois já começam os rituais de preparação. Durante esse tempo ocorrem os 
chamados ensaios, nos quais são ensinados ritmos e cantigas e as reações da futura iaô são observadas pelas mães-pequenas.

A seqüência dos rituais é determinada pelo jogo de búzios. Começa com uma limpeza que prevê um sacudimento e banhos de ervas maceradas. Alguns dias depois, e após a lavagem da cabeça com ervas especiais, se seguirá um ritual para Exu e o ritual do bori. (Verger, 1987; Vallado, 1999)

A partir daí, e observando-se o ciclo da lua, ainda conforme o que relata Verger (1981: 36), na África o início se dá no mais próximo primeiro quarto de lua; segundo a nossa pesquisa, isso também acontece na Bahia, provavelmente pelos influxos que esse astro determina sobre a natureza e pela simbologia do crescimento (do qual a lua é o símbolo principal).

A inicianda deixa atrás de si sua antiga vida com uma cerimônia na qual abandona os próprios vestidos velhos e rasgados e toma banho numa fonte de água doce, como símbolo de renascimento.

Mais tarde, ela se recolhe em clausura, fato que significa uma morte simbólica (para o mundo) e renascimento. A inicianda está vestida de branco num quarto que representa a gestação no útero.

A reclusão completa dura de 12 a 16 dias, dependendo do orixá. A inicianda, enquanto permanece no roncó, é mantida fora do alcance de qualquer notícia ou evento da vida exterior. As raras visitas são as dos outros iniciados, que têm que estar de corpo limpo. Mas, sobretudo, a inicianda deve perder a memória de sua antiga personalidade, pois é levada a um estado de perda temporária da consciência. Conforme Verger,

"Durante o periodo de iniciação, o noviço é mergulhado num estado de entorpecimento e de dócil sugestibilidade, causado, em parte, por abluções e beberagens de infusões preparadas com certas folhas. Sua memória parece momentaneamente lavada das lembranças de sua vida anterior. Nesse estado de vacuidade e de disponibilidade, a identidade e o comportamento do orixá podem se instalar livremente, sem obstáculos, $e$ se lhe tornar familiar" (Verger, 1981: 44).

Depois do ritual da raspagem dos cabelos (raspar o santo), são feitas algumas incisões na cabeça e no corpo. Sobre as incisões no alto do crânio é colocado o oxu, um composto de vários ingredientes: folhas, raízes etc. ,que são condutores de axé. Será através dessas incisões que o orixá entrará no corpo da fiel.

O abiã torna-se adoxu, que significa portador de oxu (Verger, 1981: 44-45), ou iaô, esposa do orixá. A cabeça é completamente raspada, como a de um bebê. Às vezes em ocasiões especiais, ou em candomblés de outras tradições, a cabeça é comprada: paga-se, simbolicamente, para não ter a cabeça completamente raspada.

De acordo com Verger, a iniciação na Bahia é similar àquelas que se faz na África. Durante a reclusão são organizadas sete saídas (sete é um numero dinâmico e está ligado aos caminhos pelos quais vem Ogum) para um público restrito da casa, as ebômis mais velhas e pessoas da família. Nessas saídas o corpo da filha-de-santo deve se acostumar bem à energia do orixá, pois a energia do dono da cabeça molda o corpo da sua sacerdotisa. 
Na primeira saída as iniciadas têm a cabeça recoberta de pontos brancos, feitos com giz efum em homenagem a Oxalá, o Criador. Elas chegam no quarto da saída - que no terreiro do Axé é na casa de Oxalá - tendo à frente as suas mães-pequenas, que as norteiam, e estão protegidas por um pano branco (alá) esticado em cima delas. $\mathrm{Na}$ frente há sempre alguém de Ogum, aquele que abre o caminho, pois foi ele o primeiro a pisar na Terra. Elas andam com a cabeça baixa e são muito dóceis. Esteiras são estendidas: diante da porta da sala, diante dos atabaques, diante da porta do quarto de Oxalá e na frente da mãe-de-santo. Sobre a esteira as iaôs realizam a saudação ritual (o dobale) para os orixá masculinos e o icá para os orixás femininos e fazem o característico paó (batidas de mãos para demonstrar respeito), uma vez que devem ficar em rigoroso silêncio. Além disso, dançam algumas de suas coreografias.

Na segunda saída, as cabeças são pintada de azul anil em homenagem a Ogum, que abre os caminhos. A cerimônia é bem parecida com aquela precedentemente descrita. Na terceira saída elas são pintadas também de vermelho, osum, a terceira cor da criação.

Conforme Vallado (1999),

"(...) o branco, alem de ser a cor de Oxalá, representa a calma, tranqüilidade e imortalidade. $O$ azul representa o poder de transformação, energia e agitação. $O$ vermelho do ossum representa a realeza."

Parece, conforme a pesquisa, que essas saídas, as cores e as formas com as quais as iniciadas são pintadas nos falam da origem do cosmo e, em última análise, da origem e da identidade da pessoa, e, depois, daquela energia especial que a iniciada carrega, seu orixá. Apesar de existirem fotografias de saídas de iaô, nas antigas casas queto é realmente muito raro vermos uma iniciação e, da mesma maneira, a cerimônia do nome que, embora aberta ao público, tem no Axé ${ }^{106}$ várias restrições.

Apos a feitura, entenda-se a raspagem da cabeça, o barco de iaô permanece ainda no roncó, num estado de consciência chamado de erê, no qual são apreendidas as danças dos orixás e as rezas. Conforme Cossard-Binon (1981: 129),

"Treinamentos metódicos estabelecem condicionamentos que são desencadeados por um certo número de sensações definidas. O comportamento ritual obedece assim a um padrão rigoroso, tanto na intimidade quanto em público, e jamais cede lugar à anarquia". Quando o orixá volta para a terra, ele deve dançar os mitos e o menor gesto, o menor passo, têm sua importância. As iâ̂s devem, além de conhecer e transmitir o patrimônio cultural à comunidade, também passar as mensagens que o orixá destina aos seres humanos, tanto aos membros do terreiro quanto às pessoas à sua volta."

Chega-se ao dia da saída de iaô ou cerimônia do nome, na qual a própria adoxu irá dizer o nome do seu orixá ${ }^{107}$. Essa é uma cerimônia de grande emoção.

Depois dessa cerimônia, a iaô pode voltar ao seu lugar na sociedade, submetendo-se antes a uma outra cerimônia - que ocorre num clima de festa e alegria, pois a ia $\hat{o}$ nasceu outra vez -

\footnotetext{
${ }^{106}$ No Axé é proibido fotografar os orixás e é difícil fotografar também as situações do dia-a-dia.

${ }^{107}$ Com a iniciação as pessoas recebem um nome litúrgico em iorubá, que pode ser revelado em sonho, devendo ser avaliado pela mãe ou pai-de-santo.
} 
chamada panã (Herskovits, 1957; Verger, 1981), na qual a iniciada reaprende suas antigas atividades: varrer a casa, costurar, cozinhar etc. Depois do panã, a nova sacerdotisa ainda deve ficar no terreiro por um mês ou mais, conforme seus deveres e a vontade dos orixás. Durante esse período as iaôs usam o quelê: um colar ajustado ao pescoço que simboliza a completa submissão ao orixá. Elas andam descalças e, no começo, se vestem de branco e, mais tarde, com as cores de seu orixá, completamente paramentadas com várias contas. Elas usam, ainda, um guizo no tornozelo, chamado xaorô, que deixa qualquer um de seus movimentos audíveis e, portanto, controláveis.

Descrevo a seguir a cerimônia do nome, observada num terreiro derivado do Axé Opô Afonjá, o Axé Opô Aganju, situado em Lauro de Freitas e conduzido pelo pai-de-santo Rubelino de Xangô, filho de Mãe Senhora, e por isso ligado ao Axé Opô Afonjá por laços de parentesco espiritual, sendo ambos são da mesma tradição. Esse pai-de-santo também é ligado aos cultos dos Eguns na Ilha de Itaparica e por isso pudemos observar em sua casa algumas danças de Oiá ${ }^{108}$ que nunca vimos no Axé Opô Afonjá. A saída de iaô ${ }^{109}$ aconteceu no dia 21 de janeiro do 2001. era um barco de cinco pessoas destes orixás: Ogum, Oxalá, Oxóssi, Xangô e Omulu.

Na primeira saída no barracão, as iniciadas estavam vestidas de branco, pois o branco é a cor de Oxalá, o pai da Criação, e estavam acordadas ${ }^{110}$, conforme era costume de Mãe Senhora. Chegaram embaixo de um lençol branco conduzidas pela mãe-pequena. Uma delas saudou a porta, os ancestrais, fazendo o dobale sobre uma esteira, pois ela era de Ogum, enquanto as outras saudaram a porta de pé. As cantigas saudavam os ancestrais, pois sem eles, as iniciadas não poderiam sair por aí cantando, dançando e, principalmente, mostrando os poderes dos orixás.

Na segunda saída as iaô chegaram vestidas com as cores dos orixás aos quais pertenciam, e na terceira chegaram paramentadas com luxo, com os vestidos e os objetos sagrados dos seus orixá. Nessa última saída, os orixás mesmo dizem os nomes de seus orixá que, assim, são identificados. Na segunda e na terceira saída, por outro lado, as iaô estão em transe e são sempre conduzida por alguém. Nessas últimas duas saídas canta-se muito para Iemanjá, porque ela é a mãe de todos os orixás e das cabeças. As cantigas dizem que ela está alegre, pois o orixá está firme como um rei, significando que ele foi colocado na cabeça. Cantam-se também cantigas para identificar cada um dos orixás do barco.

Apos a feitura, as iaôs do barco ficarão unidos para sempre por laços espirituais, estreitamente fixados, até o ponto em que, quando uma delas adoece ou sofre qualquer outro problema, as demais experimentam algo similar.

A aprendizagem da conduta da iaô é rígida, pois a disciplina imposta às filhas-de-santo é muito forte, tanto que para uma pessoa de fora pode parecer excessiva. Gisele Cossard-Binon

\footnotetext{
${ }^{108}$ Danças ligadas ao culto dos eguns, no terreiro de antepassados situado na ilha de Itaparica. Outro terreiro de eguns, o de Mestre Didi, filho carnal de Mãe Senhora, que foi a terceira ialorixá do Axé Opô Afonjá, está situado em Salvador, no bairro de Patamares.

${ }^{109}$ Essa cerimônia parece ser uma imitação das saídas de iaôs que se dão durante o recolhimento da feitura.

${ }^{110} \mathrm{Na}$ linguagem do candomblé, dizer que alguém está acordado significa dizer que não está em estado de transe. Se se fala que alguém está dormindo, significa que está recebendo o orixá.
} 
(1981) e Vivaldo da Costa Lima (1977) enfatizam a idéia de como a trajetória religiosa de um iniciado nos terreiros de candomblé pode remeter à idéia de servidão nos moldes semelhantes aos vividos pelos escravos nas senzalas. De fato, a hierarquia nos terreiros é severa e seus mandatários podem até tomar atitudes despóticas para com os filhos-de-santo, mas isso não é regra geral para todos os terreiros.

É importante, contudo, enfatizar que existe algo mais no candomblé que remete à senzala: além da estrutura hierárquica e da disciplina que regula qualquer religião (ou disciplina iniciática), percebe-se nos terreiros a lembrança de um sofrimento que ainda resiste forte e que foi experimentado por ancestrais dessas mesmas sacerdotisas. As filhas-de-santo enfrentam ao longo da sua nova vida uma série de proibições, chamadas euós ou quizilas, que se referem a alimentos, cores, lugares, tarefas e atitudes. Alguma dessas restrições valem para todas as filhasde-santo de um mesmo terreiro; outras, para todas as filhas de um mesmo orixá; outras, ainda, de indivíduo, conforme a descoberta de seu próprio odu (destino). Há também uma série de proibições que acompanharam a filha-de-santo em seu primeiro ano da feitura, como presenciar as festas de egum, ir aos hospitais; entrar no mar, enfim, freqüentar lugares onde se encontram situações de sofrimento ou de morte, pois a feitura é o nascimento, é o começo, e deve acontecer com a maior energia saudável possível.

Um importante meio de contato com o orixá é o jogo de búzios, um oráculo de conchas (ver Braga, 1988; Prandi, 1994, 1996) que atualmente é jogado de uma maneira simplificada. Durante a feitura é constantemente consultado, pois é ele que determinará os deveres e as proibições da filha-de-santo. Através do jogo de búzios encontra-se também o odu (destino individual), que acompanha a iaô desde o seu nascimento e lhe é revelado quando a iâo, por si mesma, joga os búzios, simbolizando que ela toma seu destino na próprias mãos.

O jogo de odu é fundamentado sobre o conhecimento dos 256 diferentes odus, caminhos que contam várias histórias sobre os orixás. Eles, pelo fato de terem emoções e sentimentos, várias vezes violam seus eúos, causando desse modo danos para si mesmos, danos que podem muitas vezes serem consertados por meio de oferendas.

\subsubsection{O assentamento}

O assentamento é o altar do orixá, mas essa palavra também significa sua preparação, realizada durante a feitura ou numa cerimônia anterior, que também impõe recolhimento na clausura, geralmente por uma semana. O assentamento, isto é, a fixação do orixá no seu assentamento, ibá, ou altar, é a representação material do orixá. No caso das aiabás, trata-se de vasilhas de porcelana ou de louça com uma tampa (sopeiras, por exemplo), nas quais são colocados os otás - as pedras dos orixás - suas ferramentas, búzios etc., havendo uma grande variedade de arranjos que dependem de cada orixá especifico, de suas qualidades etc. No Opô Afonjá, esses objetos são guardados nas casas de cada orixá ou num quarto especial chamado quarto das aiabás, localizado perto do quarto de Oxalá. Os assentamentos são lavados uma vez por mês, numa cerimônia chamada ossé, que se faz na primeira semana de cada mês - tendo cada orixá o seu dia da semana. Nesse dia são abertos para essa cerimônia as casas dos orixás em 
questão e o quarto das aiabás. Nas cerimônias sacrificiais, essas vasilhas recebem o sangue dos animais abatidos em oferendas, o que se faz nas festa do orixá, nos assentamentos e na feitura de cabeça das filhas-de-santo, e outras obrigações, estabelecendo-se e renovando-se o pacto de cuidados recíprocos entre o orixá e seus devotos. O sangue é símbolo da vida e da força.

Para finalizar, ao longo da feitura ocorrem dois atos paralelos de fixação do orixá, na cabeça da iaô e no assentamento do orixá, o que reafirma a ligação entre a pessoa e o orixá e prepara a iaô para incorporar a sua divindade. Cada filha-de-santo tem seus assentamentos, pois cada um dos diversos orixás que compõem a pessoa tem a sua representação material. Em caso de necessidade ou simplesmente para rezar, a filha se dirige ao seu assentamento particular, pois ali foi fixado o seu orixá.

\subsubsection{As obrigações}

A iniciação, conforme Mãe Stella de Oxóssi (1993), somente se encerra com a última etapa das obrigações, que acontece no sétimo ano após a primeira reclusão. Isso significa que com a feitura não termina o processo iniciático, mas começa, simplesmente, o percurso ritual.

Desde a feitura, a devota passa por uma série de rituais denominados obrigações, que se realizam no primeiro, no terceiro e no sétimo ano, sendo estes dois últimos os mais importantes, são finalizados com uma cerimônia pública. Com a obrigação do sétimo ano, a devota passa do status de iaô ao de ebômi, termo que significa "minha irmã mais velha", e a fiel passa a ter o direito de presenciar as iniciações e ter conhecimento de seus fundamentos, isto é, sua fórmulas rituais e doutrinas secretas. Essa última obrigação constitui uma repetição da feitura e a filha-desanto permanece no roncó por apenas sete dias.

Nos sete anos que passam desde a iniciação até alcançar o status de ebômi, a filha-desanto deve aprender as lendas, as danças, os cantos, as artes manuais, enfim, todo o repertório das artes rituais que estruturam o candomblé, pois, como já foi relatado, o saber não é diretamente ensinado, mas transmitido nos rituais e adquirido através da observação e da participação no silêncio.

Com a obrigação dos sete anos a ebômi recebe o decá, uma cabaça que contém os objetos necessários à realização de uma feitura. Com a entrega do decá ela está habilitada a dirigir a iniciação e, finalmente, a abrir seu próprio terreiro, embora se acredite que nem todos são chamados a serem mãe ou pai-de-santo. A partir desse momento a ebômi deve oferecer um animal ao seu orixá a cada ano a fim de fortalecer mais o seu contato com ele. As 14 e 21 anos outras obrigações são celebradas. Até a cerimônia final do axexê, rito fúnebre que, após a morte, deve desfazer todos os laços que em vida ligaram o devoto ao orixá e à comunidade de culto.

\subsection{A aprendizagem, a escuta e o silêncio}

"A linguagem dos sábios é o silencio." 
Nas sociedades de cultura oral, a aprendizagem acontece de maneira diversa das sociedades ocidentais, pois nas primeiras se acredita que ela se dê por meio da atenção e da concentração, de modo que somente mais tarde é que o aprendiz interiorizará as noções envolvidas. A memória é um bem muito útil e se usa da para que o ato, a palavra, o canto seja internalizado inconscientemente. Acredita-se que essa maneira de aprender opera uma transformação interna que acalma as ondas da mente e que contribui para o desenvolvimento da sensibilidade e da receptividade como conhecimento.

Então a escuta atenta e silenciosa acompanhada de virtudes como a paciência, a humildade e o respeito para com os mais velhos que são os detentores do saber, são qualidades extremamente apreciadas. A abiã, a filha-de-santo recém iniciada, deve escutar quase intuitivamente as palavras das velhas a fim de conhecer as coisas e mais tarde saber reproduzilas.

\section{Conforme Cossard-Binon (1981: 41),}

"(...) o ensino nunca se faz de modo sistemático. 'Isto vem com o tempo...', dizem as mais antigas. Desta forma, através de um hábito lentamente adquirido, o saber da yawo incrusta-se no mais profundo de seu ser."

A escuta pura, livre de outros pensamentos, portanto, permite a intelecção das palavras, enquanto que a repetição aquieta a mente e produz um relaxamento que leva as fiéis à abertura das percepção dos sentidos. Por exemplo quando se come a comida de um orixá, as velhas ebômis sugerem, várias vezes, que se faça isso em silêncio e com calma, no intuito de saborear o prato e sentir as emoções que isso nos dá; e mesmo na preparação das festas é aconselhado manter uma postura tranqüila.

No candomblé, como na África, a ligação entre poder e palavra foi bastante estudada (Calame-Griaule, 1982; Santos, 1977). O saber, e por conseguinte o poder, está subordinado aos atos de escutar e ficar em silêncio.

Típica é a postura corporal das abiãs e das filhas-de-santo perante a mãe-de-santo e ebômis. Elas mantém uma postura quase dobrada, com a cabeça para baixo, nunca olham nos olhos dos mais velhos (Cossard-Binon, 1981). As ebômis podem autorizar a nova iaô a se levantar, caso esta demonstre paciência e humildade. Quando têm que entregar algo, as iniciadas sempre o fazem com as duas mãos, para simbolizar um equilíbrio das partes do corpo, reflexo de um equilíbrio interior. Podemos falar também em dois tipos de aprendizagem: um que se dá num estado de consciência normal - ao se prepararem as festas, por exemplo - , outro que se verifica estando as iaôs num estado de leve transe - no roncó, quando aprendem as danças, as rezas e a postura dos orixás, em estado de erê, conforme relata Verger (1957: 91).

"É neste estado, em um espírito livre de toda lembrança anterior, que serão inculcados os ritmos particulares dos orixás, seus cantos, suas danças e todo o comportamento dos deuses." 


\subsubsection{A aprendizagem dos papéis}

Conforme Prandi (1991a),

"O primeiro papel a ser interiorizado é o do erê, depois o papel do orixá. Quero, entretanto, chamar a atenção para o fato de que esses papéis são papéis vividos religiosamente e, portanto, desempenhados e sentidos a partir de um código de comportamento que é código religioso. (...) na sociedade, o comportamento vem junto com o código; às vezes o comportamento se mantém quando o código já foi esquecido e o código pode sobreviver ao comportamento — assim, um papel pode ou não estar provido de sentido. Nas conversões religiosas, o novo comportamento passa a ser vivido junto com a crença; ação e código são uma coisa só. Ao mesmo tempo que o indivíduo age, interioriza-se o sentido da ação, de cada gesto."

A inicianda, ao desempenhar o papel de erê - intermediário entre seu eu profano e o orixá sagrado - "internaliza o conjunto de regras intimas e públicas que regem este comportamento e dão a ele sentido próprio" (Prandi, 1991a). A mesma coisa se dá quando a filha-de-santo deve internalizar o papel do orixá, do segundo orixá e, depois, em algum casos, o de seu caboclo ${ }^{111}$. A inicianda, então, desenvolve uma multiplicidade de eus sagrados que atuam nos rituais, além do seu eu social, que é a expressão das regras sociais internalizadas por ela.

Dessa maneira, e ainda conforme Prandi (1991a),

"O eu profano do indivíduo é o seu eu social. É o conjunto de papeis através dos quais ele se expressa publicamente e intimamente. Expressar-se significa mostrar-se através de posturas, gestos, ações, linguagem, símbolos, emoções e enunciados."

Segundo Prandi, as religiões de transe buscam integrar as dimensões íntimas e públicas do eu social com aquelas que estão circunscritas aos papéis dos eus sagrados que parecem estar separados do eu social da pessoa, mas que na verdade estão interligadas. Eus sagrados são eus profundos, escondidos, que a iniciação revela e integra no todo da pessoa. A iniciação expande e multiplica as possibilidades de expressão. Assim a iniciada tem uma experiência enriquecedora no candomblé, pois ela pode manifestar uma multiplicação de eus sagrados que antes estavam segregados dentro dela mesma. Essa possibilidade que o candomblé oferece de se experimentar a complexidade e multiplicidade da vida interior é reparadora e abre um grande espaço de liberdade interior, que aumenta quando os fragmentos são integrados. As emoções ligadas a cada parte espiritual são profundas e podem ser representadas e exibidas num ambiente propício e acolhedor, o do rito do transe, o que abre uma grande possibilidade ao ser humano para integrar a sua multiplicidade.

${ }^{111}$ Em alguns antigos terreiros de nação queto o culto é exclusivamente dirigido aos orixás, não se cultuando caboclos e outras entidades de origem brasileira. Mas na maioria dos terreiros, de forma mais ou menos reservada, cultua-se o caboclo, para o qual a iniciação consiste numa cerimônia simples de "chamada". 


\section{Capítulo 6:}

\section{A EXPERIÊNCIA DO TRANSE E O CORPO MÍSTICO}

\subsection{Transe e possessão: teorias interpretativas}

O fenômeno do transe é conhecido no mundo inteiro, pois é um fenômeno do ser humano, representado diferentemente segundo as culturas nas quais acontece. Lapassade (1990) o define como sendo a "consciência modificada, caracterizada por uma mudança qualitativa da consciência ordinária, da percepção do espaço e do tempo, da imagem do corpo e da identidade pessoal".

Os primeiros estudos sobre o fenômeno do transe nas religiões afro-brasileiras foram feitos pelo médico Nina Rodrigues (1935), que pesquisou sobretudo no Gantois, no tempo de Mãe Pulquéria, terreiro no qual teria sido suspenso ogã. De acordo com as idéias científicas do final do século XIX, Nina Rodrigues considerava a possessão como um estado sonambúlico que favorecia a dissociação e a substituição de personalidade — induzida também pelo hipnotismo sendo, por isso, semelhante às perturbações histéricas. Rodrigues aceitava, assim a noção ocidental de pessoa, que enfatiza a unidade do eu. Pouco tempo depois, Ramos (1940: 283), também médico e antropólogo, associava a possessão não só à histeria, mas aos múltiplos tipos de perturbação mental que se originariam de uma "regressão" que, por sua vez, alcançaria "estados efetivos profundos, arcaicos".

Após as publicações de Bastide (1974; 1978), que formulou uma nova concepção sobre esse assunto, a explicação do transe como fenômeno patológico foi deixada de lado . Para ele o transe, núcleo das religiões afro-brasileiras, deve ser pensado como um fenômeno normal e social, definindo-se os cultos de possessões como um conjunto de "variáveis funcionais", nas 
quais as funções manifestas e as funções latentes articulam-se de várias maneiras, originando um sistema muito complexo. Resumindo a tese de Bastide, ressaltamos que:

a) os cultos de possessão são formas de vivência religiosa caracterizadas por um tipo de relação entre a divindade e determinadas categorias de seus fiéis; essa ligação ocorre de maneira que o fiel seja possuído pela divindade;

b) a possessão em si é um comportamento socializado, isto é, aprendido. No íntimo do fiel acontece uma mudança na qual a personalidade normal, que determina os comportamentos habituais, cede seu lugar à personalidade do orixá, que atua com comportamentos diferentes. Essa substituição é acompanhada de uma alteração do estado psíquico chamada geralmente de transe;

c) a identificação que assim se realiza, constrói um tipo de pacto de recíproca aliança, cuja função principal é garantir a proteção do orixá tanto para o fiel quanto para o grupo ao qual ele pertence.

Bastide entende os cultos de possessão como uma forma de psicodrama nos quais os fiéis podem expressar seus conflitos emocionais. Em sua "sociologia do misticismo", ele tenta explicar as mudanças na expressão das experiências religiosas como se elas fossem determinadas pela mudança das estruturas sociais.

Costa Eduardo (1948) e Ribeiro (1952) insistem na natura socialmente adaptativas do transe. Os autores defenderam a tese de que o transe é uma forma intencional de protesto das classes desprivilegiadas, uma maneira de inverter seu status social, uma vez que os indivíduos, possuídos pelos espíritos, se tornam divindades e ganham prestígio e respeitabilidade na comunidade.

Também Verger (1981) encara a possessão de um ponto de vista sociológico e psicoanalítico, percebendo o transe como um reflexo condicionado no qual uma personalidade inconsciente do fiel possuído tem a possibilidade de aflorar e de se expressar num contexto social controlado.

Márcio Goldman (1987), de uma perspectiva estruturalista, polemiza com as velhas interpretações biopsicológicas e com os modelos sociológicos reducionistas. Para ele, uma compreensão maior do complexo fenômeno do transe deve ter como ponto de partida uma prévia análise da estrutura ritual e da noção de pessoa dentro do contexto ritual no qual o culto se desenrola. Assim, Goldman examina o processo da iniciação no candomblé como uma construção ritual da nova personalidade do indivíduo.

Muitos estudos foram feitos sobre a possessão não só no candomblé mas em várias áreas culturais em que se manifesta. Leiris (1988 [1958]) e Metraux (1971 [1958]) consideram a possessão nos seus aspectos teatrais como se fosse uma comédia do sofrimento e da marginalidade. Também Bourguignon (1976) situa-se um pouco nessa linha, mostrando que os estados alterados de consciência nas religiões não ocidentais são muito difusos. Para ela, os possuídos agem como atores, uma vez que, através da mudança de papéis, desenvolvem um balanceamento entre as necessidades pessoais e as expectativas sociais. De Martino (1994) e Boddy (1994) propõem o transe como uma prática do discurso político de crítica corporal contra a hegemonia. Outros estudos ainda, como os de Lewis (1972), situam a possessão como uma resolução de conflitos existentes na estrutura social, especialmente entre mulheres e homens. 
As linhas interpretativas de Neher (1962) e Goodman (1988), que tentaram explorar os aspectos das alterações neurofisiológicas nos estados de consciência alterados, tiveram muitas interpretações ligadas às esferas da biopsicologia.

Voltando ao contexto afro-brasileiro, Cossard-Binon (1970), Lépine (1978), Verger (1981) e Augras (1983), entre outros, concebem os cultos de possessão como definidores de um arquétipo característico que permitiria a liberação de uma tipologia psicológica mais ou menos escondida no inconsciente. Há, porém, muitos outros fatores que favorecem o desenvolvimento desse fenômeno, como o da solidariedade do grupo e o da participação comunitária. Todas essas abordagens demonstram o quanto é difícil de se compreender o transe e também as múltiplas possibilidades que levam ao seu acontecimento e orientação.

Para podermos discutir esse aspecto da possessão e o seu envolvimento corporal é bom sublinhar as diferenças, inclusive as lingüísticas, entre os termos que descrevem a fenomenologia mística: êxtase, possessão e transe.

Segundo Rouget (1986), a primeira distinção a ser feita é entre o êxtase e o transe. O primeiro acontece em completa imobilidade, no silêncio, na solidão, sem que haja uma crise evidente e com a presença de visões ou alucinações; o transe, por sua vez, ocorre com o movimento, em presença da música e de outras pessoas, com a ocorrência de uma crise evidente e sem alucinações. Conclui dizendo que o transe e o êxtase podem acontecer por ocasião de rituais diferentes, com as mesmas pessoas e dentro da mesma fé religiosa.

Outra distinção a ser feita é a entre transe xamânico e de possessão. Sempre conforme Rouget, o xamanismo é identificado como uma viagem que o xamã decide fazer no mundo dos espíritos para trazer de volta a alma do "paciente"; no transe de possessão, no entanto, é um espírito (ancestral, orixá) que entra no corpo da fiel e a possui. Esse segundo tipo está ligado a tradições da África e da bacia do Mediterrâneo (e na América da diáspora africana), enquanto que a primeira, às áreas culturais indígenas americanas e asiáticas. Ele define a possessão como sendo:

"(...) um comportamento socializado de um indivíduo que, dadas algumas circunstâncias especiais, consiste numa mudança que nele acontece, com o efeito de que a sua personalidade usual (que atua no seu comportamento cotidiano) se transfere para a divindade, que provoca diferentes formas de comportamentos; essa substituição deve ser acompanhada por uma alteração da atividade psíquica chamada, geralmente, de transe" (Rouget, 1986: 30).

Entendemos a possessão segundo essa definição de Rouget - e não como uma dissociação mental - e a propomos como um complexo comportamental que expressa uma relação entre o indivíduo a e divindade. A possessão, portanto, implica um "comportamento identificatório", fundamentado por nós sobre um saber corporal que se identifica com o próprio orixá.

Tanto quanto pude observar, a fenomenologia mística é muito ampla e complexa e está de acordo com muitos tabus existentes no candomblé. Diante disso, minha descrição e análise, apesar de termos participado de perto de muitos atos de possessão, não pode ser considerada completa, acabada. Há também outro problema a considerar: o transe é uma experiência 
individual e, por isso, de difícil alcance. O transe, assim como outros fenômenos interiores, é algo difícil de descrever, pois, conforme Prandi (1991a: 138):

"O transe no candomblé, pelo menos em suas primeiras etapas iniciáticas, é experiência religiosa intensa e profunda, pessoal e intransferivel. Como a dor e as paixões nãoreligiosas experimentadas, não pode ser mensurado nem descrito, a não ser metafórica e indiretamente."

Mesmo assim, tentarei apresentá-lo descritivamente, mostrando minha interpretação, que tenta compreender a experiência do transe como uma compreensão do corpo, o qual, em circunstâncias especiais, experimenta uma ampliação da consciência ordinária. Trata-se de um estado profundo de meditação no qual os limites entre o externo e o interno não existem mais, pois o indivíduo faz parte do mundo e o mundo faz parte do indivíduo.

\subsection{A possessão pelo orixá}

$\mathrm{Na}$ terminologia do candomblé existem várias palavras para relatar as experiências místicas que não sejam a possessão pelo orixá, a saber, irradiação, aproximação e vibração. Essas palavras, tomadas do espiritismo kardecista, estão relacionadas à intensidade da influência do orixá sobre a filha-de-santo. Como sensações, invisíveis, tais fenômenos e manifestam-se no corpo da fiel com menor intensidade do que a possessão propriamente dita, mas indicam a proximidade da incorporação.

A irradiação é uma forma de sentir a "presença" do orixá, o qual pode afetar o médium com intensidade variável e pode acontecer em várias situações rituais, como nas oferendas de comida aos deuses ou na limpeza dos altares. Os sintomas são, habitualmente, a perda parcial da consciência e alguns outros sinais físicos, como sentir arrepio, frio, certa letargia ou, ainda, taquicardia. Usualmente se diz no candomblé que essa é uma etapa anterior à da verdadeira possessão.

Desse modo, a irradiação corresponderia ao que Rouget (1986) chama de obsessão, que é causada por um "agente externo", diversamente, então, da possessão na qual age um "princípio interno" que prevê a moradia dentro do corpo de um espírito, ou orixá ou ancestral. A irradiação pode ser causada seja por um espírito malévolo (ou melhor, negativo) ou por um orixá.

Rouget (1986: 25) estabelece também uma outra distinção entre possessão e inspiração; para ele a primeira pode ser definida como:

"A possessão é caracterizada pelo fato de que, durante o transe, o sujeito é entendido como ganhador de uma diferente personalidade: a da divindade, do espirito, do gênio ou do ancestral - pelo qual podemos usar o termo geral 'divindade' - que toma posse do sujeito, substituindo-se a ele, e atuando agora no lugar do sujeito (...) por um periodo maior ou menor, o sujeito torna-se a própria divindade. Ele é deus. Podemos chamar essa possessão no stricto sensu da palavra." 
Já quanto à inspiração, Rouget a define assim:

"Ao contrário de mudar a personalidade, o sujeito é pensado como sendo investido pela divindade, ou pela forca que dele emana, que coexiste, de qualquer forma, com o sujeito, mas que o controla e o provoca a agir e a falar em seu nome."

Uma ulterior e básica distinção entre a possessão e a inspiração é que o autor atribui à possessão um caráter identificatório. O médium identifica-se com a sua divindade, enquanto que a irradiação não prevê uma profunda identificação com o espírito que a causa.

A vibração, por outro lado, é a percepção da energia do orixá, que pode ser alcançada por meio da sensibilidade do corpo: um leve tremor, um cansaço e, muita vezes, uma letargia sem causa aparente.

Algumas das filhas-de-santo percebem através do corpo a vibração do orixá e, por tê-la "percebida", param o movimento ou fazem uma troca de respiração que se torna diafragmática.

Há muitas palavras e expressões para dizer que uma pessoa está possuída pelo orixá. A mais comum delas é estado de santo, entendida pelas pessoas de candomblé como um afastamento da personalidades própria para dar lugar à do orixá. As filhas-de-santo dizer freqüentemente não gostar de cair no santo, o que para elas é algo desagradável. Conforme a fala de uma sacerdotisa, "é uma sensação que parece a de morrer". Outra informante, mãe Beata de Logum Edé, um dia me disse que ela ficava com pena de ver as pessoas daquele jeito, porque quando o orixá tomava a pessoa, a sensação era muito estranha. Mas essa mesma informante disse que "para obter as coisas, precisa de se sacrificar". Com isso ela queria dizer que a possessão não é algo desejável, mas algo a que as fiéis se submetem sem poder se furtar.

O orixá vem para dançar e mostrar os seus poderes, representando em gestos suas ações míticas, e a filha que o recebe tem que suportar isso, para isso ela foi iniciada. A possessão pelo orixá indica que a filha-de-santo já passou pela iniciação: seu orixá foi educado a ter a postura correta e a dançar seus ritmos e cantigas. A dança é a própria manifestação da experiência mística de ser possuído, um fenômeno que discutirei mais a frente.

Algumas pessoas têm uma certa predisposição pra receber o santo. Conforme se acredita no candomblé, o orixá escolhe seus sacerdotes. Esse tipo de sensibilidade não está ligado a um grupo étnico específico, e qualquer pessoa pode vir a manifestar sua mediunidade, a respeito da qual podia anteriormente não ter sabido nada. Um dos velhos sacerdotes da Bahia nos contou que quando era jovem não acreditava que os brancos tivessem orixá, mas desde então ele viu muita coisa. Segundo ele, o orixá é como uma raiz de uma grande arvore que pode ir onde quiser.

As sacerdotisas reconhecem as pessoas que têm essa predisposição de cair no santo. Apesar do orixá poder nunca não ter se manifestado antes no corpo de uma determinada pessoa, haveria uma série de sinais corporais que se essa pessoa teria ou não dor de receber o orixá em transe, sinais que as velhas iniciadas dizem reconhecer.

A predisposição de se receber o santo pode acontecer em vários momentos, inclusive antes da feitura. Quando ele vem, inesperadamente, antes da iniciação, é chamado de santo bruto, que significa que ainda não foi educado, lapidado. De acordo com Bastide, o santo bruto ocorre 
quando o transe ainda não foi socializado. Cheguei a observar isso pelo menos em duas situações. Numa quarta-feira, uma moça - que tinha vindo ao terreiro para o jogo de búzios — estava sentada num dos sofás da sala de espera e, sem nunca ter tido esse tipo de sensação, foi tomada por tremores e chegou a desmaiar. Mais tarde, e já revigorada, ela continuava insistindo que nunca havia tido relação com o candomblé e que não sabia o que pensar disso. Numa outra casa, um jovem recém chegado para assistir a uma sessão de caboclo, ao se aproximar do lugar onde ficava a estátua do caboclo, começou a tremer violentamente e logo depois caiu no chão numa crise verdadeiramente impressionante, da qual foi recuperado somente com a ajuda da mãe-desanto e de outras sacerdotisas que se mobilizaram ao seu redor.

Quando o orixá se manifesta e a pessoa é chamada a zelar do santo, ela deve se submeter ao ritual da feitura, que dará uma nova ordem e proporcionará um novo equilíbrio à "cabeça" do indivíduo. Os objetivos da feitura, como já disse, são os de domesticar, educar e lapidar o santo, pois a pessoa deve aprender a controlar a sua mediunidade e a comunicar-se com sua divindade. A manifestação do orixá deve acontecer em momentos e situações oportunas ritualmente controladas, não devendo ser jamais violenta. A filha-de-santo deve aprender a lidar com o transe através do treinamento que desenvolve ao longo de sua participação na comunidade do terreiro. Mas, como dizem no candomblé, "quando o orixá quer vir, ele vem e ponto final".

Uma filha-de-santo nos contou sobre um fato curioso que ocorreu com ela. Certa vez, estava sentindo uma vontade enorme de conversar com uma sua irmã de candomblé, mas não conseguia entender o porquê disso. Então, num domingo à tarde, ela foi à casa dessa irmã e, de repente, quando alcançara a porta, chegou o orixá dela, e o orixá incorporado e acabou fazendo um "trabalho" naquela casa. Ela falou que o seu orixá tinha percebido mal fluidos e teve que ir trabalhar. Muitos casos desse tipo me foram relatados, como que para confirmar a idéia da vontade superior do orixá.

O processo de aprendizagem, antes e durante a feitura, tem uma grande importância. As abiãs, quando em estado normal de consciência, devem aprender a dançar no xirê, a primeira parte do ritual público. Será o próprio orixá, no entanto, que deverá se acostumar a assumir determinadas posturas corporais, como a de pôr as mãos do lado esquerdo da cintura (gesto sinalizando que é um santo novo, recém iniciado). Evidentemente, cada terreiro tem modo próprio de ensinamento da sua tradição.

A quantidade de manifestações de cada orixá depende da predisposição pessoal para o transe. Por um lado, a regra dita que as iaôs devem ser possuídas freqüentemente, enquanto as ebômis raras vezes. Por outro, isso é algo de pessoal e de difícil padronização. Normalmente, as sacerdotisas passam a ser possuídas cada vez menos quanto maior sua idade no santo, seus tempo de iniciação, mas isso, repito, não é uma lei inflexível. Variações podem ser explicadas, também, pelo lugar ocupado pela sacerdotisa na estrutura hierárquica do terreiro. Há, por exemplo, uma relação muito forte entre as filhas-de-santo que foram iniciadas juntas, no mesmo barco, e o orixá dessa filhas se manifestam conjuntamente, numa cadeia de incorporações ${ }^{112}$.

\footnotetext{
${ }^{112}$ A ligação entre as sacerdotisas de um mesmo barco é tão forte que chegam a passar mal até adoecer se uma delas teve qualquer tipo de problema, pois existe uma ligação muito forte entre as pessoas dentro dessa religião.
} 
Num ritual público, há vários fatores que desencadeiam a manifestação de determinados orixás, e não de outros. Os laços de parentesco mitológico, por exemplo. Numa festa para Ogum com certeza irá aparecer Oiá, com a qual Ogum teve relações amorosas. Oxóssi, pelo fato de ser seu irmão, irá dançar junto dele, assim como Iemanjá, a sua mãe. E assim por diante. Numa festa de Iemanjá pudemos ver este orixá dançando na frente de um sacerdote de Ogum: foi até ele e passou, dançando, uma ponta de sua saia em seu rosto. Subitamente o Ogum dele se manifestou, e com Ogum veio Oxóssi. Assim, para se compreender um pouco de cada festa de candomblé, é indispensável conhecer a mitologia dos orixás.

O poder da mãe ou do pai-de-santo sobre as filhas-de-santo é tamanho que eles podem chamar o orixá de suas filhas somente com palavras ou com o uso da campainha adja ${ }^{113}$. Podem simplesmente passar um braço ao redor da cabeça da filha e apertar, e a manifestação do orixá será imediata.

\subsubsection{A possessão na iniciação e o estado de erê}

Retomando que já tínhamos falado no Capítulo 5, ao longo do processo de reclusão iniciática, as filhas-de-santo são levadas a um estado de transe no qual é possível educar o orixá e moldá-lo no corpo das sacerdotisas. Isso se dá com o uso de várias técnicas, como a aplicação de banhos com ervas especificas, ingestão de comida especial e ensaios de dança. Muita importância é dada à manifestação e às posturas que o orixá toma porque, através delas, entende-se quem ele é, qual é a sua história mítica, e qual sua função cósmica e social.

Além do transe do orixá, existe um transe definido como "mais leve", o chamado transe ou estado de erê, descrito na literatura como um estado de semi-transe (Rouget, 1986). O erê é um tipo de entidade infantil que acompanha o dono da cabeça, o orixá. Segundo Verger, ele é "aquele que chega com uma bagagem", em iorubá: "erê asere inu eru de" (Verger 1969: 53)

O erê parece um orixá criança que se manifesta sempre de olhos abertos, com fala e comportamento infantilizados. Usualmente apresenta expressão fixa e inocente, mas pode chegar a falar de tudo na frente de todo mundo, inclusive inconveniências. Sendo estritamente ligado ao seu orixá, o erê manifesta todas as características dele. Por exemplo, os erês de Ogum gostam de brincar com brinquedos de metal, os de Oxum adoram sabonete e perfume. Usualmente o estado de erê, que tem duração variável, acontece após o orixá ter sido despachado depois de dançar na festa pública. Em muitos terreiros são chamados no momento em que o orixá, recolhido nos aposentos privados, deve ser paramentado para dançar.

Pelo seu comportamento, podemos ver que o erê faz uma ponte entre o profundo estado de santo e a consciência ordinária da filha-de-santo.

Os nomes dos erês são em português, ao contrário daqueles dos orixás, e eles mesmos se auto-nomeiam. Acredita-se que recebem o nome em sonho, nome que pode ser confirmado ou

\footnotetext{
${ }^{113} \mathrm{O}$ adja é uma sineta de grande importância ritual. Conforme pude observar no Axé Opô Aganju, de Lauro de Freitas, e na Casa das Águas, de São Paulo, o pai-de-santo pode provocar o transe simplesmente tocando a campainha perto da cabeça da filha-de-santo.
} 
não no jogo de búzios pela mãe ou pai-de-santo. O erê de uma filha de Ogum pode chamar-se Espadinha ou Soldadinho, assim como o de uma filha de Iemanjá pode ser Estrela-do-Mar, enquanto o erê das filha de Xangô pode ser chamado Foguete ou Trovãozinho (Verger, 1981: 47).

A linguagem dos erês é bastante típica. Eles falam de si mesmos na terceira pessoa e cada objeto tem um nome na sua linguagem próprio, como o café chamado de "água preta" ou a carne de "falecido". Eles põem na boca tudo aquilo que encontram — folhas, terra, fruta etc. — sendo necessário, portanto, um controle atento sobre eles a fim de que não exagerem demais. Eles, furtam de tudo também, até coisas sem valor.

As pessoas têm certo receio dos erês porque eles falam demais, são indiscretos, fazem artes e gostam de brincadeiras violentas. Eles adivinham com grande facilidade e falam diretamente na cara das pessoas o que lhes passar pela cabeça. No final de uma festa, presenciei certa feita um deles jogar uma torta no rosto de uma pessoa que estava na platéia. Contaram-me histórias de um erê que revelou a uma moça a infidelidade do namorado; e de um outro que jogava comida na cara das pessoas que ele considerava antipáticas, chamando seus nomes em voz alta. Mas ninguém no candomblé reprova o comportamento do erê, uma vez que as regras da boa educação são abolidas no estado de erê. Por outro lado, parece que, nesse estado, os bloqueios e recalques da pessoa são resolvidos e podem emergir do inconsciente livremente. Não é raro um erê contar segredos pessoais ou confessar ações indesejáveis cometidas pelo filho-de-santo que o incorpora. Mas os erês também podem se mostrar muito educados.

Curiosamente, o erê quando incorpora já apresenta todos os comportamentos e conhecimentos do filho-de-santo. Ele sabe dançar e cantar para o orixá e sabe tudo o que se passa com seu filho. Ele chama quem o incorpora de "meu filho" e o orixá deste de "meu pai" ou "minha mãe". Como é criança, chama todo mundo de "paizinho" e "mãezinha". Recados e pedidos ao orixá podem ser falados diretamente ao erê, que também traz mensagens do orixá.

\subsubsection{A possessão fora do contexto ritual}

O transe pode acontecer também fora do contexto ritual ${ }^{114}$, em situações particulares, como em momentos de nervosismo ou de tensão emocional, de desespero, de preocupações etc., como pude testemunhar em várias ocasiões. Uma vez, uma filha-de-santo que passava por grande tensão nervosa, com problemas afetivos e de trabalho, chegou no terreiro num evidente estado de agitação. De repente, começou a hiperventilar e fazer movimentos quase mecânicos que se manifestam na irradiação. Após ter sido despachado o orixá, ela mesma relatou estar se sentindo aliviada e tomada de grande calma, que se podia ver na expressão do seu rosto.

Segundo falam as velha ebômis, o orixá pode chegar também para punir a filha-de-santo que não se comportou bem. Dizem que antigamente havia muito mais punições de orixá, como nos relatou uma sacerdotisa, ao contar de uma filha que não tinha vontade de participar de uma

\footnotetext{
${ }^{114}$ Fiz essa pergunta diretamente a uma mãe-de-santo e ela confirmou que o transe pode acontecer em muitas situações, sendo que em certas situações o orixá chega para nos acalmar e nos aliviar.
} 
festa: primeiro ela foi presa pelo orixá na casa dela e depois veio a pé para o terreiro, de muito longe. Da porta do terreiro, foi bolando no chão até chegar à entrada do barracão.

Outra vez, numa situação completamente fora do ritual de um certo candomblé, presenciei o seguinte fato ocorrido com uma filha de Iemanjá. Durante a festa de 2 de fevereiro - dia de Iemanjá na Bahia -, estávamos com algumas pessoas do Axé na praia do Rio Vermelho, local da festa, perto da casa dos pescadores. Era de tarde e os presentes já tinham sido oferecidos. Conversávamos sobre a festa, próximos ao lugar onde há feira do peixe, quando, de repente, Simone, uma filha de Iemanjá, que tinha a obrigações já bem adiantadas no Axé, mas ainda sem a iniciação completa, começou lentamente a ser irradiada. Foi algo muito forte e estranho, pois nunca tínhamos visto nada assim. A experiência pela qual ela passou é algo de muito íntimo e de difícil compreensão, mas tentarei descrevê-la. A filha-de-santo começou a se tornar mais velha e parecia que o seu corpo estava se alargando; os braços se posicionaram como se ela colocasse as mãos sobre os quadris; seu rosto tinha uma expressão de serenidade. Um irmão dela, depois de alguns momentos, veio em seu socorro e lhe ofereceu um copo d'água. Ela andava muito devagar e nos disse apenas que estava muito cansada ${ }^{115}$ e que tinha percebido a "presença" do orixá, no caso Iemanjá, como algo que entrava pela sua cabeça e que a recobriu como se alguém tivesse lhe botado um manto. Uma onda leve, mas muito profunda, conforme a fala da moça, tinha entrado nela, paralisando os seus movimentos, deixando-a com uma grande paz.

Há toda uma mitologia sobre fatos como esse, contados e recontados pelo povo-de-santo. Geralmente, quando uma manifestação ocorre fora do contexto ritual, fala-se que o orixá é forte. Esses transes não aconteceram em presença da música, ou em contexto ritual, mas foram desencadeados por estados emocionais de forte tensão em pessoas predispostas a esse tipo de experiência espiritual.

Para finalizar, lembro que certa vez, quando me encontrava na cozinha do terreiro, várias filhas e filhos-de-santo conversavam sobre essas experiências de santo. Perguntavam um ao outro como era ser possuído, o que cada um sentia, e davam risadas dizendo que nem eles saberiam explicar ou descrever tal experiência, pois cada vez que acontecia era uma experiência diferente, uma experiência nova.

\subsection{A chegada do orixá e a sua partida}

Em geral a incorporação do orixá é lenta e raramente se percebe seu início. Pode durar alguns minutos, e ser mais rápida, ou parar e recomeçar de novo. Usualmente cada filha-de-santo tem sua maneira própria de sentir a aproximação do orixá, o que evidencia o caráter individual do transe.

No contexto ritual, as filhas-de-santo comumente "caem" ao final do xirê. Algumas começam a sair da roda, dão um passo e depois parecem cair num buraco; outras coçam o rosto

\footnotetext{
${ }^{115}$ Apesar de ter presenciado esse episódio e testemunhado as transformação dessa filha-de-santo, fato que na época me chocou bastante, não me senti à vontade para perguntar mais nada.
} 
ou atrás da orelha; outras tapam os ouvidos (ou põem uma das mão sobre a orelha); outras param por alguns segundos ou andam mais lentamente, ou, ainda, cambaleiam ligeiramente; outras fazem movimentos descontrolados com os braços; outras rodam em torno do próprio eixo até serem sacudidas violentamente. E depois de terem rodopiado, com os braços estendidos ou com um braço esticado ao longo do corpo, o orixá se manifesta completamente. O orixá estica os braços sobre a cabeça à frente dele, cruza os braços atrás das costas, curva-se diante o público e grita o seu ilá característico, diferente para cada orixá. O ilá é a identidade sonora do orixá, e não se repete de um para outro orixá pessoal (orixá desta ou daquela filha-de-santo), havendo, contudo, um padrão para cada orixá geral: ouvem-se piados nos ilás de Oxóssi, choro nos que são emitidos pelas diferentes incorporações de Iemanjá, um som parecido com heeei nos ilás de Iansã etc.

O xirê continua e outras sacerdotisas seguem dançando na roda. Há as que saem correndo, não querem ser "tomadas", mas que depois de alguns passos são presas pelo orixá completamente. As velhas ebômis se sentam, mas se alguma delas incorpora o orixá, o que não é muito freqüente entre as "velhas", as outras filhas dão gritos de felicidade. Logo o orixá se levanta e se dirige aos atabaques, esperando que toquem para ele.

Cada orixá tem um jeito próprio de possuir seus filhos, havendo também distinções características cada orixá. Assim, as filhas de Iemanjá têm movimentos lentos e muitas param o andar, enquanto as filhas de Oiá são rápidas e dão muitas voltas sobre si mesmas. Os filhos de Omulu voltam os olhos para cima e se dobram para frente e para atrás com grande mobilidade da coluna vertebral.

Deve ser acrescentado que cada casa de candomblé também tem seu padrão de incorporação, mesmo quando se trata de terreiros de mesma origem. No Axé Opô Afonjá, por exemplo, as filhas-de-santo rodam sobre si mesmas; na Casa Branca, o corpo se curve para o chão e para atrás, desenhando um grande arco. O desequilíbrio do corpo é grande e as equedes socorrem as filhas-de-santo colocando uma mãos atrás das costas e outra na frente do peito da filha, como se demarcassem limites de movimento dentro dos quais o equilíbrio é restabelecido. No Gantois presenciei orixás demarcando sua chegada definitiva no corpo de seus filhos com um salto para o ar.

Varia também de uma casa para outra a forma de despachar o santo, cujas fórmulas são mantidas em segredo. No Axé, para alguns orixás, isso é conduzido nos quartos localizados na parte traseira do barracão, ou nas próprias casas, no caso de Omulu, Nanã ou Oxumarê, ou, ainda, para Xangô. Em cada terreiro há uma técnica que corresponde evidentemente aos fundamentos da casa, usando-se, por exemplo, cobrir a cabeça do orixá com um pano branco e fazer uso da água das quartinhas (Querino 1938: 80; Ribeiro 1952: 58; Landes 1967: 60-62). É comum no candomblé dizer que é muito perigoso ter o santo despachado de forma não usual, pois a matéria, isto é, a filha-de-santo poderia acordar sem poder a fala ou ouvir, ou padecendo de outros desconfortos. Quando a filha-de-santo "acorda", isto é, quando recupera sua identidade, mostra-se meio atordoada, com um olhar completamente ausente, caminhando sem equilíbrio. Precisa ser amparada por alguém ligado a ela, como uma das filhas-pequenas ou uma amiga, que a ajuda na volta para casa. Ela acorda muito cansada, com sede e com a sensação de ter voltado de uma 
longa viagem. Geralmente é necessário passar algum tempo para que recupere o senso de orientação.

Apesar de eu não ter presenciado nenhum despacho de orixá de iniciados, vi como se despacha o santo bruto, isto é, o orixá de quem ainda não é feito e cai no barracão durante um ritual público. Usualmente seu corpo é apertado em vários pontos (nos ombros, nas costas, nas mãos e nos pés), puxam seus cabelos e sopram nos seus ouvidos, às vezes chamando a pessoa pelo nome. Usa-se também a água para molhar o rosto e as mãos dessa pessoa.

O estado de santo ocorre corriqueiramente nas festas públicas do terreiro. No Axé Opô Afonjá são realizadas cerca de 25 festas por ano, mas os orixás se manifestam de acordo com um calendário. Normalmente o orixá chega nos dias de festa a ele consagrados. Xangô desce nas suas festas e nas de Oiá, pelo fato de ela ser a esposa com a qual divide o poder do fogo, e desce também na festa de Oxum, que é outra de suas esposas. Oxóssi, além de aparecer na sua própria festa, se manifesta também nos dias consagrados às aiabás, nas festas de Ogum e de Iemanjá. Oxalá que, pelo fato de ser um orixá lento e velho, manifesta-se apenas nas festas do ciclo das águas a ele dedicado. Iemanjá também não desce facilmente, sobretudo as qualidades velhas, como Iemanjá Sabá. Existem, no entanto, uma multidão de outros fatores, dos quais já falamos, que desencadeiam o transe dos orixás específicos.

Uma plena compreensão da ligação e da interdependência entre o estado de santo, o estado de erê e o comportamento da pessoa no estado de consciência normal se torna difícil pela dinâmica estritamente pesssoal presente em cada caso.

Feita esta ressalva, podemos afirmar por ora, para resumir, que o transe, ou estado de santo, envolve um conjunto de fenômenos que, apesar de contidos num modelo comum culturalmente padronizado, são experimentados diferentemente por cada indivíduo. Pessoas com uma sensibilidade particular para experimentar tais fenômenos são socializadas através da feitura, que contém o modelo disciplinador dado pela cultura.

O comportamento no transe é modelado ou disciplinado pelo processo de aprendizagem implícito na etapa iniciática da feitura, com o fortalecimento de laços entre a filha-de-santo e seu orixá, com a assimilação pela filha dos traços típicos do orixá (dono da cabeça) que a possui, e pela fixação no corpo da iniciada dos modelos de comportamento e posturas corporais transmitidos por meio das cantigas, toques e mitos.

A freqüência com que se dá a possessão do orixá e o estado de erê varia em função de muitos fatores. De modo gera, uma filha-de-santo recém iniciada cairá em transe com mais freqüência do que uma que já concluiu a obrigação de sete anos, pois uma ebômi experimenta o estado de santo cada vez mais raramente. As mais velhas no santo experimentam o transe só uma ou duas vez por ano, pois elas "conversam com o orixá de outra maneira", nas palavras de Mãe Almira. 


\subsection{A aprendizagem no candomblé}

A aprendizagem no candomblé é sobretudo corporal e se dá por meio de um habitus que é exercitado durante a estadia no terreiro, num nível de consciência ordinária, no caso das abiãs, e ao longo da feitura, no caso das iaôs ou filhas-de-santo, quando elas se encontram em estado de erê. No roncó as filhas-de-santo aprendem a soltar os ombros e a deixar sair o ilá, conforme me foi dito por Mãe Beata de Logum Edé. Aprende-se na prática, pois no candomblé não existem aulas ou textos escritos, e sim trabalho. É o corpo que, trabalhando, aprende a sentir e se imbui das novas regras a serem atendidas.

Nos primeiros tempos, a abiã começa a freqüentar o terreiro com assiduidade. Ela aprende a se comportar na presença dos mais velhos, a ter uma postura correta, a saudar os orixás, a fazer pequenos trabalhos. Em geral, aprende a etiqueta do candomblé. Ela começa a ter uma certa familiaridade com as ebômis, e essas lhe narram os mitos do candomblé e as histórias de uma ou outra filha-de-santo, ressaltando ao máximo a magia do candomblé e o desenho do destino de cada um. As velhas traçam histórias que mostram a obrigatoriedade de se entrar para candomblé, como se a vida de muitas pessoas tivesse somente essa finalidade. Usualmente a abiã tem uma ligação forte com sua mãe-de-santo e sempre a procura para orientação, aconselhamento, ou simplesmente para conversar e estar junto dela. Se essa ligação não é assim tão estreita, há sempre por perto uma das velha ebômis que procura ajudar e aconselhar a recém chegada. Comumente, as abiãs colaboram na preparação das festas, enfeitando o barracão, ou ajudando na comida, mas apenas na limpeza das verduras, pois cozinhar é um das obrigações das ebômis.

A cozinha é um dos pontos centrais para as mulheres de um terreiro, pois ali é o seu reino, e são poucos, de fato, os homens que se atrevem a nela entrar. Os homens acabam por se ocupar de trabalhos pesados, mas podem auxiliar na limpeza da comida. A cozinha é um dos lugares mais sagrado do terreiro, pois é onde são preparadas as comidas dos deuses. Todo mundo passou por ali e muitas são as conversas e os casos mágicos ali relatados. É justamente nesse ambiente que começa a aprendizagem de uma futura filha-de-santo. E ali ela é observada em tudo o que faz, ali as velhas procuram entender a sua índole mais profunda e antever os sinais do orixá.

No Axé Opô Afonjá há duas cozinhas. A mais antiga, localizada nos fundos da casa de Oxalá, é bastante ampla e dispõe de dois fogões, vários bancos e um grande pilão. A outra, menor em tamanho, fica na casa de Xangô e usualmente é lá que se prepara o seu amalá às quartasfeiras.

Durante uma festa de Oxóssi, tive a oportunidade de ajudar na limpeza das galinhas, o que foi feito de manhã, depois da matança. Pude observar a postura das mulheres: a maioria vestida de branco ou com uma saia florida, com o torço na cabeça, cada uma sentada em seu próprio banco, com a sua faca e a sua bacia. Era algo muito bonito de se ver, pois as pessoas trabalhavam com grande euforia, cada uma dizendo que tinha "muito que pedir", pois a vida era difícil. As conversas variavam muito, falava-se das últimas abiãs chegadas — se elas tinham ou não o santo; se elas deveriam fazê-lo ou não etc. —, mas foi tudo interrompido com a chegada de uma delas. Algumas sacerdotisas estavam trabalhando fora da cozinha, pois dentro havia outras que 
estavam já cozinhando sobre os grande fogões. O calor era muito forte. Ao redor de uma mesa um grupo de mulheres depenava as galinhas, enquanto um outro grupo retirava delas o axé, as partes destinadas ao orixá. Cada grupo ou pessoa em separado depenava, limpava, cortava, mas sobretudo contavam-se histórias e se falava sempre de algum assunto relacionado ao candomblé, comentando-se de que é dever de todos trabalhar nas festas dos orixás.

Ali, na prática, tem início a escola do candomblé. As velhas mostram às jovens como se tratam as galinhas: primeiro são escaldadas em água fervente, depois são depenadas e passadas sobre o fogo para que percam a penugem remanescente. Um fato curioso: uma abiã que estava colocando a sua galinha na água, deixou sem querer sua saia ficar em contato com o fogo. Logo, logo foi avisada por uma das ebômis, que assim disse: "Minha sereia, você quer que a sua cauda pegue fogo? Não faça assim, mas bote a saia no meio das pernas quando está na frente do fogo!"

Depois, uma das velhas pôs-se junto à recém chegada e, com tranqüilidade, mostrou-lhe como cortar a galinha e tirar seu axé. Ela disse: "Olhe aqui, que hoje sou eu a te mostrar, assim um outro dia você não precisa pedir a ninguém. E lembre de trazer a sua faca! Agora, faça atenção e nunca pergunte no candomblé, mas observe e depois faça!" A velha estava ensinando a regra de ouro: a aprendizagem no candomblé se dá na prática, na observação constante e na repetição de gestos, de tarefas, de posturas que se reproduzem desde sempre.

Inesperadamente uma outra abiã quase caiu com o rosto sobre a galinha. Logo aproximou-se uma sacerdotisa dizendo: "Essa também vai para a UTI. Venha comigo, filha. Hoje é demais para você!", e a levou para dentro da cozinha, enquanto uma outra lhe oferecia um copo d'água dizendo: "Agora respire, que vai passar!".

Começa assim o treinamento da abiã, na cozinha, em estado de consciência normal. Mais tarde virá o aprendizado no roncó.

Os conselhos simples dados às mais jovens aos poucos vão tornando familiar a estrita etiqueta do terreiro, e elas aprendem a se comportar na frente dos mais velhos ou do orixá, aprendem quem deve receber a comida primeiro, quem são as pessoas mais importantes etc.

As abiãs conversam muito entre si e contam as coisas mais extravagantes. Atraídas pela magia que emana do candomblé e pela doçura das mais velhas e da mãe-de-santo, acompanham, o quanto podem, tudo aquilo que acontece no terreiro. Elas se sentem importantes, pois foram escolhidas, e o fato de se sentirem reconhecidas pelo próprio orixá as deixa ainda mais felizes e cheias de si. Sentem-se gente importante. Elas fazem de tudo para se aproximar da mãe-de-santo e conversar com ela, ter sua atenção.

Começa, assim, uma aprendizagem que poderia ser a de crianças, pois as abiãs são consideradas crianças: elas nada sabem e, por isso, têm o direito de errar. Observam tudo atentamente e procuram a mãe-de-santo a cada minuto para perguntar ou dizer algo, como se tudo dependesse delas.

Nessa primeira etapa iniciática do candomblé, essa forma de ensinar deixa os devotos aprendizes à vontade para que possam se expressar e, por acerto e erro, aprender. 


\section{Capítulo 7:}

\section{MÚSICA, TRANSE E O REFLEXO DO SAGRADO}

\subsection{O som e o ouvido}

O ouvido é, segundo Guyton (1987), um sentido " nobre" e "superior", pois aquilo que se percebe com o ouvido é algo que foge às percepções dos outros sentidos. $\mathrm{O}$ som, segundo a física quântica, é um conjunto de ondas que se propagam através dos corpos gasosos, líquidos e sólidos até alcançar uma certa distância de sua fonte, percorrendo uma distância determinada pela intensidade. $\mathrm{O}$ som, portanto, pode ser entendido como um impulso, um movimento, uma força dinâmica que produz alguns efeitos ou sensações, não obrigatoriamente apenas auditivas (Faldini Pizzorno, 1997: 153). Por exemplo, a música não produz em nós somente sensações para os ouvidos, mas também efeitos muito mais complexos, pois as ondas sonoras passam por nosso corpo e mobilizam uma série de processos metabólicos resultantes da interação entre as ondas sonoras e a nossa corporeidade.

Assim, o som não é algo perceptível através do ouvidos, mas algo de concreto que vibra, se movimenta e movimenta as coisas e as criaturas do universo.

O som é movimento, comunicação:

"A música fornece um canal de comunicação entre o mundo dos vivos e dos espíritos e serve como meio didático para transmitir o conhecimento sobre o grupo étnico de uma geração para outra" (Mukuna, 1996: 207).

No entanto, há momentos, sobretudo quando se trabalha manualmente para o orixá como cortar verduras ou limpar os altares - , em que chega repentinamente uma vibração, como se diz no candomblé, uma irradiação da divindade, que se manifesta de várias maneiras: ou em 
forma de voz, ou de uma força que, para o corpo, transmite alguma mensagem, alguma intuição. Acredita-se que esses momentos usualmente acontecem na solidão e quando se tem a mente tranqüila ou, como dizem, de cabeça fria, de cabeça vazia. Pareceu-me que o pesado trabalho braçal que antecede, por exemplo, uma festa de candomblé, ajuda a esvaziar a mente e a preparála para receber o orixá. Conforme as representações do candomblé, essas vibrações produzidas pelos orixás podem nos afetar de vários modos, através de visões, de sons, de palavras e até mesmo fazendo as filhas-de-santo rodar sobre si mesmas, como pude observar diversas vezes no terreiro.

Mãe Stella, quando fala aos seus filhos, sobretudo na ocasião do jogo do começo do ano $^{116}$, alerta as pessoas para falar menos e tentar servir e ouvir o orixá de coração aberto. Tomamos um pensamento da ialorixá Valnizia Pereira, do terreiro do Cobre, no Engenho Velho da Federação (Harding, 2000: 147): ela interpretou o trabalho que antecede a festa pública de candomblé como uma memória incorporada do trabalho feito pelos escravos no Brasil, enfatizando que esse é um tipo de comunicação com os ancestrais, uma continuação do processo através do qual o axé foi cultivado e transmitidos no Novo Mundo.

Temos a impressão, então, de que o trabalho braçal feito pelas filhas e filhos-de-santo na preparação das festas seja uma homenagem aos ancestrais, mas também um modo para afastar os pensamentos do cotidiano, para se liberar das tristezas e se preparar para o orixá. Nesse sentido, lembramos as palavras de uma sacerdotisa de Oiá, ebômi Sandra, que durante uma conversa no terreiro nos relatou sua interpretação sobre o trabalho para a festa:

"Os escravos eram tratados mal, vocês sabe, então toda a depressão, o medo e o sofrimento podiam sair fora só através do trabalho duro. Eu mesma, quando acordo ás três, quatro horas da manhã com aquela sensação de coração apertado, levanto $e$ preparo a comida para o dia, ou passo roupa, não fico me deprimindo mais".

Voltando a nosso assunto principal — o do som e do ouvido - , várias vezes vi as filhasde-santo cair em transe ou se dobrar sobre si mesmas apenas pelo fato de estarem olhando para o quarto de Xangô ou cortando as verdura etc. Presenciei numa quarta-feira o seguinte acontecimento: as oferendas já estavam na frente do peji, mas ainda não tinha começado nenhum canto. As pessoas estavam se aproximando, quando, ao entrar uma ebômi, veio com ela uma espécie de onda que pegou várias fiéis (desde a porta de entrada até o quarto de Xangô) e provocou a incorporação de pelo menos sete ou oito pessoas.

Com esse exemplo percebe-se que o ouvir poderia ser considerado um sentido "alargado", pois não se escuta somente através dos ouvidos, mas através da pele, do corpo que envolve o fiel como um todo, como se ele tivesse uma compreensão corporal "total", adquirida ao longo do processo ritual-iniciático.

\footnotetext{
${ }^{116}$ A cada $1^{\circ}$ de janeiro, às 10 ou 11 horas, Mãe Stella joga os búzios na frente do pejí de Xangô para ver qual será o $o d u$ do ano e assim sinalizar aos seus filhos o ebó do ano e alertá-los de possíveis perigos.
} 


\subsection{A estrutura dinâmica da música}

Como propõe Snyder,

"A música, a dança e a arte, todas podem ser consideradas a literatura de uma sociedade de cultura oral, por isso possuem uma estratificação de sentidos: a história da etnia, a visão de mundo, as crenças religiosas, a organização da sociedade e várias funções interligadas como a de fortalecer o grupo e o conhecimento da comunidade sobre si mesma" (Snyder, 1979: 213).

Nas sociedades ágrafas temos um tipo de conhecimento que é transmitido através de uma linguagem não verbal. Isso ocorre provavelmente porque a forma, sobretudo nos rituais religiosos, está diretamente implicada na transmissão do conteúdo (Tambiah, 1979).

Falando em termos fenomenológicos, a música é uma tecnologia que nos revela o mundo (Heidegger, 1977). Tendo como base o princípio de que o som, no candomblé é o resultado de uma interação dinâmica entre as vibrações que se propagam do tambor percutido pelos alabês (os sacerdotes-músicos); o som então é entendido como condutor de axé (poder de realização), que aparece com todo seu conteúdo simbólico nos instrumentos musicais considerados sagrados.

Entramos, assim, no campo das percepções estéticas que são opostas às do Ocidente, onde se entende o conceito de ritmo e de sua transformação em movimento apenas como uma organização temporal da música ou da poesia. Já na cultura africana, o ritmo significa "impulso" e cria movimento, algo tanto material quanto ideal (Lühning, 2000).

"O ritmo é a arquitetura do ser humano, a dinâmica interna que lhe dá forma (...) $O$ ritmo se expressa através dos meios mais materiais: através de linhas, cores, superfícies e formas de pintura, na plástica e na arquitetura (...) Através dos acentos na poesia e na música; através dos movimentos da dança. Com esses meios o ritmo reconduz tudo no plano espiritual: na medida em que ele sensivelmente se encarna, o ritmo ilumina o espirito" (Senghor, 1956, p.60).

Desse modo, a principal característica da música africana e, em seguida, da afrobrasileira $^{117}$ é a percussão rítmica. O ritmo, então, é considerado energia cinética, energia que capta e propulsiona a vibração do movimento pessoal e do outro.

Lühning (2000) ressalta a pouca compreensão que muitas pessoas manifestam quando consideram a música de candomblé como sendo simples, repetitiva e até monótona. Apesar da incompreensão, confirmam uma uniformidade estilística entre as cantigas, embora essas pessoas não consigam captar as funções e as características do repertório. A música durante a festa pública tem várias funções, como a de criar e manter a base sonora para a festa toda, louvar os orixás, chamá-los por meio das músicas e dos toques, criar a atmosfera para que o transe aconteça, mantê-lo, trazer a memória dos ancestrais e dar lembranças etc.

\footnotetext{
${ }^{117}$ Sobre a questão da identificação da cultura afro-brasileira com a cultura africana, ver Prandi (1991a) e Vallado (1997).
} 
Watermann (1952) foi um dos pioneiros na compreensão da música africana segundo novos padrões. Enfatizou os conceitos de senso metronômico, de predominância da percussão, de polimetria, das acentuações melódicas com off-beat e das frases de perguntas-e-respostas que se entrelaçam. Mas somente os estudos mais recentes, como os de Kubik, (1979), Nketia (1974) e Chernoff (1979), entre outros, permitem uma nova visão e descrição da música africana.

O termo timeline, criado por Jones (1959), significa "linha de tempo" ou "linha guia" e é um padrão rítmico que se baseia na acentuação assimétrica de uma pulsação elementar, geralmente com a base de 12 ou 16 pulsos, tocado, normalmente, por um instrumento de timbre agudo e marcante, como o agogô, que serve como base para o ritmo do conjunto dos instrumentos e da dança (Lühning, 2000).

Conforme Lühning:

"Esta estrutura do timeline pattern encontra-se também no repertório dos orixás. Essa base rítmica permite uma intensificação de expressão e de velocidade, um acelerando durante um periodo considerável, que, juntamente com frases melódicas curtas $e$ coreografias próprias, adapta-se bem às finalidades extra-musicais do contexto como um todo, o qual visa à evocação do orixá".

Para entendermos a função e o sentido simbólico da dança e da música no ritual, é necessário lembrar que o candomblé apresenta algumas das características básicas das religiões africanas, como, em primeiro lugar, a de ser uma religião holística. Cada aspecto da vida é ligado a um outro e, portanto, no ritual o ritmo é ligado à dança e ela, por sua vez, às cantigas, numa corrente em que é difícil evidenciarmos o começo e o fim. Assim, o momento ritual esforça-se para voltar ao momento do mito (da origem) e para recriar aquele tempo, aquela antiga harmonia. A música, nesse contexto, adquire uma importância especial por ser a vibração do orixá e o meio através do qual ele se canaliza.

Por esse motivo, os estudiosos da artes e das civilizações africanas - como Asante (1985:72) e Thompson (1974:30) - reconhecem na pulsação, quer dizer, no movimento, o aspecto mais importante e profundo da estética das culturas africanas e das afro-americanas, tanto na dança e na música, quanto em todas as artes. A dinâmica, como já vimos, é um dos conceitos fundamentais da ontologia africana, segundo a qual há a possibilidade de transformação da vida através da união e da troca com o mundo espiritual.

Outro dado fundamental está na importância do grupo e, em última análise, do ritual, pois a comunidade vive e recebe energia do que se considera o mundo espiritual. Segundo essa concepção, cada indivíduo participa, desempenhando seu papel em âmbito cósmico e social, e deixando a "energia circular".

Há alguns critérios estéticos, ainda conforme Asante (19850 e Thompson (1974), que são aplicáveis a todas as artes, como por exemplo, o conceito de polirritmia, no qual a existência de vários padrões rítmicos nos acentos principais não coincidem, mas se sobrepõem uns aos outros crucialmente. Corresponde a um movimento no qual cada parte do corpo está trabalhando: os pés seguem a base rítmica musical, os ombros e os braços contam as histórias; enquanto que o corpo inteiro executa as variações de direções. O corpo está dividido em partes que se harmonizam 
numa única sinfonia, porém, como sugere Thompson, existe um pattern (padrão ou módulo) de pulsação elementar interna que coordena e sincroniza cada parte do corpo ${ }^{118}$.

Isaura Oliveira ${ }^{119}$ muitas vezes nos explicou que a dança afro-brasileira é uma ponte entre um ponto fixo dentro da pessoa e a capacidade de movimentar as partes externas, as quais são coordenadas para um imóvel impulso pessoal interno.

Lühning (2000) enfatiza:

"Deve-se observar a própria execução musical em sua relação com a dança não somente em termos gerais. Mas concretamente, observando a complementação rítmica realizada pelos pés, a qual acaba resultando em um efeito sonoro rítmico forte, completado e alterado, ainda, pelo arrastar dos chinelos".

Para compreender melhor a música do candomblé temos que enfatizar o fato de que na África a comunicação pelos tambores está diretamente relacionada com a oralidade, ou seja, com as línguas, mostrando assim uma unidade indissociável. No Brasil esse fato foi reformulado, não havendo mais línguas africanas cotidianamente, mas apenas na linguagem ritual.

Outro conceito importante é o da repetição. Segundo o músico Carneiro (1997):

"Na música existem alguns padrões fixos, como a ciclicidade da frase musical. Quer dizer que o padrão rítmico repete-se ao infinito. Não é como na música ocidental, na qual se cria uma história temporal. O padrão rítmico se repete sem um começo ou um final. É o master drum, o rum que sinaliza o começo e o final da execução. Parece que existe a tentativa de parar o tempo e o seu fluxo na busca interior de um "centro" único, fixo e eterno"

Kasadi ${ }^{120}$ sublinhou várias vezes em 1997, a importância da repetição, que cria cada vez algo de novo e dá força a isso. No ritual parece haver um esforço de criar-se, todas as vezes, a origem, a fonte primordial de axé. Assim, na festa de Iemanjá, por exemplo, cria-se a própria energia da água do mar, e esta é reoriginada através da repetição do ciclo musical, do movimento da dança e dos rituais que antecederam a festa. Dançando e cantando a mesma cantiga três vezes, produz-se a energia sagrada do orixá.

Nesse sentido, Fanta Touré, dançarina senegalesa entrevistada em Milão em $1999^{121}$, esclareceu que a repetição não é algo de frio ou mecânico, mas a possibilidade de nos perdermos dentro do som, afastando nossos pensamentos cotidianos e fundindo-nos com a música num todo no qual até quem toca é levado, como se fizesse parte da energia da música. Outra característica

\footnotetext{
${ }^{118}$ Nesse sentido lembro uma vez que assistimos a um samba de roda em Cachoeira, por ocasião da festa da Boa Morte, no qual um rapaz negro, sambando, rodava sobre si mesmo, mas o seu olhar e a expressão do rosto estavam firmes e distantes.

${ }^{119}$ Isaura Oliveira é dançarina e coreógrafa. Trabalhou com o Grupo Olodum e como professora na Universidade Federal da Bahia. Agora mora e leciona nos Estados Unidos. 'E uma das melhores especialistas da dança de Oxum e foi uma excelente e preciosa informante e ajudante.

${ }^{120}$ Curso de etnomusicologia ministrado em 1997 na USP pelo Prof. Kasadi wa Mukuna.

${ }^{121}$ Entrevista concedida em Salvador, em abril 1999).
} 
de todas as artes é o policentrismo, que indica a consciência de uma pluralidade de centros energéticos no corpo, na música etc., assim como no universo.

A forma curvilínea é a forma do mito, de um tempo longínquo em que não havia começo nem fim e ao qual o rito é voltado para reatualizar o ato cosmogônico. A dimensionalidade nos fala que a música e a dança comunicam a todos os sentidos, e não só o que é visível ou audível. O ritmo-cinético deve ser experimentado, vivendo-se intensamente o sentimento, a emoção da energia da divindade que está se "manifestando".

Existe toda uma outra dimensão do tempo e do espaço, seja na música ou na dança. Nos rituais, o espaço é o da natureza que se manifesta e o tempo é um tempo do "agora". É importante estar presente e vivenciar aquele momento, aquele espaço, depois é outra coisa. O tempo é um tempo circular que inicia e acaba no mesmo ponto, cíclica e ritmicamente. O tempo torna-se, então, a materialização do movimento, como fala Duplan (1987):

"Para organizar o tempo, temos que agir, percutindo um tambor com a mão ou sobre o chão com os pés. Criando o tempo, criamos o movimento".

Pode-se entender melhor a função da música tomando-se as idéias de Carpitella (in: De Martino, 1994: 351), quando trata da música da tarantela que, embora seja ligada a uma área geográfica e culturalmente diferente (a do sul da Itália), apresenta a meu ver muitas coincidências com a função e a estrutura musical do candomblé. Lembramos que a tarantela é baseada em ritmos percussivos, também tocados através de pandeiros.

"Há uma divisão entre a pulsação da seção rítmica (sanfona, pandeiro e violão) e a pulsação de fora, o off-beat do violino (para o caráter de improvisação da parte melódica) (...) Forma-se assim uma sobreposição entre as pulsações: um ritmo isométrico puro acentuado e efeitos rítmicos atrasados, que, juntos, dão origem a uma estrutura poliritmica".

A meu ver existem dois aspectos expressos na música que refletem dois momentos típicos das técnicas rituais: a dilatação e a exasperação da crise, musicalmente elaboradas com técnicas expressivas particulares (como os ritmos acentuados, efeitos instrumentais, os vários tipos de percussão dos tambores, gritos) e o controle da crise, que se reflete, sobretudo, no obstinado ritmo isométrico. Talvez para que a polirritmia atue em função da dilatação e da exasperação da crise, o ritmo isométrico obstinado funcione como controlador e contendor da crise, pois dá o apoio necessário.

\subsection{Os alabês e a percussão dançada}

Os instrumentos são tocados pelos alabês, sacerdotes que foram escolhidos exatamente para isso. Eles são iniciados como ogãs e, por isso, não recebem orixá. Como nos informou um dos velhos ogãs da Bahia, cantor dos Filhos de Gandhi, pai Zequinha, filho de uma mãe-de-santo feita por João da Goméia (40 anos de santo):

"(...) ser alabê é coisa de grande responsabilidade. Uma vez para ter certeza que a gente não caia no santo antes de confirmar o alabê e a equede a gente tinha que passar num 
ritual onde tínhamos que ouvir todas as cantigas para ver se nenhuma tivesse efeito sobre nós".

Normalmente, esses sacerdotes são pessoas ligadas ao terreiro por vínculo familiar, como no Axé é o caso de Bié, filho do tocador principal, que é ligado desde gerações, ao Axé Opô Afonjá e que nos disse: "tocar é questão de ori".

O alabê deve conhecer todo o repertório dos toques e dos cantos. Ele tem que estar atentamente ligado aos seus colegas, pois a perda do tempo por qualquer um dos tocadores (por fadiga, por desatenção etc.) prejudicaria toda a estrutura musical. A beleza do toque não está na capacidade pessoal de um ou outro musicista, mas na capacidade de produzir uma ação coletiva. De fato, é a música que constrói o ritual, pois ela integra todos os participantes numa coletividade homogênea. Os tambores conseguem fundir as sacerdotisas num só corpo, como se todos os corpos singulares fossem ligados no ritmo de uma mesma pulsação. A música abre, liga e fecha o ritual, como se procurasse um centro fixo do qual se pode partir e também voltar.

Segundo o relato dos principais alabês no seminário "Alaiandé Xirê, Festival de Alabês, Xicarangomas e Huntós"122, foi reiterado pelos participantes que o papel dos alabês é fundamental, pois sem música não há dança nem orixás nem a estrutura do ritual. $\mathrm{O}$ conhecimento dos tocadores não se limita aos toques; eles também têm um tipo de percepção que usam ao longo do ritual, quando os orixás estão manifestados. Eles sabem como fazer alguém cair em transe, usando as variações, como quando o atabaque rum sai do ritmo dos outros dois atabaques e introduz variações, para depois retomar o ritmo usual. Essas variações se ligam provavelmente à tensão muscular dos dançarinos em transe; a intensidade dos tambores deve sustentar o ardor muscular dos dançarinos.

Os alabês podem tocar em várias casas, pois são pagos; e essa possibilidade mostra que eles têm uma liberdade de movimento que as filhas-de-santo não têm.

Durante uma festa para as aiabás no terreiro de Oxumarê, em 2 de setembro 2000, verifiquei que ao se manifestar Iemanjá, um dos velhos tocadores tirou do atabaque rum o jovem que havia pego o seu lugar e começou a tocá-lo com muita força e ênfase, olhando fixamente para os orixás, como se estivesse totalmente prisioneiro da dança. Havia uma correspondência entre a música e a dança que ligava o alabê e o orixá dançante como se ambos fizessem parte de um mesmo conjunto energético. Além de tocar, o músico tinha toda uma performance corporal especial: usando uma das baquetas (aquidavis), indicava uma pausa no toque, abaixando o corpo todo até o fundo do tambor e alongando-se como que para relaxar da extenuante tarefa, uma vez que os cantos duram pelo menos uma hora. O entrosamento no tocar crescia sempre mais, até que uns quatro velhos ogãs se posicionaram em frente dos tambores, aparentando dialogar com eles, cantando, enquanto o cantor principal, o babá-tebexê organizava a resposta das cantigas. Percebia-se uma grande emoção no ar.

\footnotetext{
${ }^{122}$ Festival que reúne os tocadores de atabaques em Salvador, no terreiro Axé Opô Afonjá. O evento tem como objetivo a preservação da tradição religiosa dos tocadores de atabaques de todas as nações de candomblé. De 8 a10 de dezembro do 2000 foi prestada uma homenagem à ialorixá Caetano Bangboxê, do terreiro Pilão de Prata, situado na Boca do Rio, em Salvador.
} 
Mais tarde, explicaram-me que a mãe de um dos velhos ogãs era de Ogum e que tinha muita ligação com aquele tipo de Iemanjá. Pelo fato de ser uma pessoa muito conhecida e querida, os da velha guarda juntaram-se e foi como se cantassem e lembrassem da família deles. "Então por isso que teve toda essa empolgação! Pela emoção e pela lembrança", explicou um informante.

Durante outra festa na Casa Branca do Engenho Velho, em 12 de novembro do 1999, por ocasião do acarajé de Oiá, vi novamente os velhos alabês darem aula de música a um jovem, usando o corpo. Não era simplesmente a instrução da parte musical, mas uma atenção global que esses tocadores tentavam transmitir ao discípulo. Nessa festa, Xangô parou várias vezes, indicando que queria que mudassem a cantiga, e me pareceu claro que se estabelecera um diálogo entre o sacerdote-musicista e o orixá, como se estivessem em sintonia. Vale a pena citar as palavras de Lühning (2000) quando diz que: "(..) no candomblé existe uma complexa integração entre visualização e a audibilização de padrões rítmicos" e que não se pode compreender o lado musical ou da dança isoladamente, porque se trata de um todo semântico no qual cada aspecto estético remete a outro na construção do orixá.

Entendo, então, que a pulsação rítmica se transmite também ao corpo do alabê, como se houvesse uma dialética entre o ouvir e o tocar, ou uma imagem acústica que se apreende tocando um instrumento. Assim, podemos propor que haja uma tensão interativa entre o acústico e a imagem musical que produz uma profundidade rítmica perceptível não só aos ouvidos mas também ao corpo todo. A música transcende o fenômeno acústico e entra no mundo da motricidade corpórea. O candomblé, devido a seu caráter físico e prático, é uma religião corporal, na qual cada pessoa participa com o seu todo. Como Friedson (1996) esclarece, a descrição da música africana tem que ir além da descrição acústica. E o bom tocador é um sensitivo que percebe a música e a dança como esse todo. De acordo com um informante,

"Os alabês, eles vêem também. Cada um no candomblé tem um tipo de mediunidade. Cada um tem um dom que a gente reforça para viver bem, isso é claro. A gente tem o dom de tocar, outros, de cantar, é assim!"

A orquestra é formada por três atabaques: o lé (o tambor menor), o rumpi (o mediano) e o rum (o maior). O primeiro deles dá início ao ritmo, o segundo o reforça e o terceiro o "dobra". Nos toque de transe, o rum faz as variações e os acentos de off-beat. Só não realiza as variações no xirê no começo da festa, quando as filhas-de-santo ainda estão em estado consciente. O rum, como dizem no candomblé, toma conta da cabeça, cabeça que manda no resto do corpo e que direciona os pés através da coluna vertebral. O rum é tocado com as mãos ${ }^{123}$ ou com uma mão e uma baqueta, e representa o "fundamento" ${ }^{124}$, isto é, dá o caráter sagrado ao ritmo. O rumpi e o lé são a base rítmica que comanda os pés. O lé produz um som seco, firme e penetrante, produzindo sons de diferentes alturas, conforme o toque dos alabês. Os sons mais "acentuados", o stress, conduzem os movimentos do orixá dançante. Assim, os dois tambores menores criam um fundo rítmico sobre o qual o rum marca as variações nas danças de transe.

\footnotetext{
${ }^{123}$ É tocado com as mãos a depender do toque e da nação.

${ }^{124}$ Com a palavra fundamento entende-se no candomblé a essência profunda das coisas da religião ou o seus ritos secretos, o que inclui alguns movimentos e alguns ritmos.
} 
Há também um instrumento de timbre agudo e marcante, o agogô, um sino duplo de ferro tocado com uma baqueta ou um pedaço de ferro (ou até mesmo uma garrafa), e o chocalho xequerê, uma cabaça com uma rede externa coberta de contas ou sementes. Ele serve como base para o ritmo do conjunto dos instrumentos e da dança.

Cada atabaque é considerado uma divindade e tem um nome próprio secreto. Por isso, os atabaques são enfeitados com grandes laços coloridos segundo a cor do orixá para os quais serão tocados no dia específico da festa. Os tambores sagrados são feitos de uma madeira bem sólida, cuja árvore tem que ser cortada numa época especial, usualmente durante a lua crescente. Antigamente, segundo pai Zequinha, a madeira era extraída à mão. Tudo começa com uma pequena cerimônia como se fosse uma iniciação: eles são deitados no roncó e recebem um banho ritual de ervas e sangue, pois não podem servir aos orixá sem esse batismo. Os atabaques - altos, estreitos e afunilados - são recobertos de um só couro. A tensão da pele é obtida com cravelhas metidas dentro da madeira do tambor. $\mathrm{Na}$ nação queto ${ }^{125}$, os dois menores são tocados com os aquidavis (varetas) enquanto o principal é tocado com uma vareta e com uma das mãos. Além do fato de serem feitos de madeira e couro especiais, os atabaques recebem sacrifícios ${ }^{126}$ a cada ano. A importância dos tambores é demonstrada também pelo fato de que, na abertura do ritual, as filhas-de-santo saúdam a porta e logo depois os tambores, sendo eles um dos pontos importantes do barracão, um centro de poder espiritual, pois são a voz do orixá.

Concluo essas considerações dizendo que a experiência musical é antes de tudo uma experiência corporal. Os alabês entram numa estrutura da música, onde dançarinos e percussionistas estão juntos em uma "presença" fenomenologicamente incorporada.

\subsection{Toques e cantigas}

Todo o candomblé é acompanhado por ritmos e cantigas que têm uma terminologia apropriada, que não é ensinada sistematicamente nem transmitida às filhas-de-santo, mas sim apreendida - como tudo no candomblé - ao longo da convivência no terreiro e por aqueles que manifestam interesse. Lühning (1990) elaborou uma catalogação das cantigas e dos toques e, conforme minha pesquisa, posso confirmar, por exemplo, que algumas vezes, as danças têm a mesma nomenclatura. Desse modo, no ritual público temos:

- Cantigas de xirê, que são aquelas entoadas durante o xirê, a primeira parte do ritual. Existe um repertório relativamente fixo de cantos que são executados em estado consciente, porque os orixás se manifestam apenas no final da seqüência com um toque especial, próprio de cada terreiro;

- Cantigas de rum são aquelas cantadas na segunda parte do ritual, quando as divindades já estão manifestadas. Cada orixá tem seu repertório. Esse termo significa que "nessa cantiga o rum

\footnotetext{
${ }^{125}$ Nas outras nações, como a angola, são tocados com as mãos e a pele é retesada de maneira diferente.

${ }^{126}$ Existe uma descrição de Herskovits (1937) sobre os tambores e o batismo deles no Haiti.
} 
executa o papel principal", pois é ele que, em grande medida, orienta e fixa os passos dos orixás. Conforme um informante: " primeiro pega o passo, depois começam os braços".

Esses cantos falam das relações míticas dos orixás e dos fundamentos, por isso são chamadas também de cantigas de "fundamento". Vejamos algumas de suas particularidades:

- Primeira de dar rum: é a primeira a ser entoada e representa um papel especial: o de anunciar ao público a manifestação do orixá. As palavras são diferentes para cada divindade; já as danças parecem ser mais similares, mas há algumas diferenças especiais ligadas ao tipo de energia da natureza do orixá. Ela introduz a segunda cantiga que se chama "dar rum ao orixá", que poderia ser traduzido como colocar o rum à disposição do orixá ou na cabeça dele;

- Cantigas de maaló ${ }^{127}$ : são as que se cantam por último (por três vezes), na hora da despedida do orixá;

- Cantigas de fundamento que seriam as cantigas que obrigam o santo a vir, elas têm uma forte influência sobre quase todas as filhas-de-santo e provocam a manifestação dos orixás. Há também ritmos que têm o mesmo poder. Essas cantigas são encontradas durante o período de exploração musical que se dá na feitura e conserva seu efeito sobre a iniciada para o resto de sua vida. Uma mãe-de-santo, para destacar o poder delas, certa vez me disse: "e agora quem tem cabeça se segure!";

- Toques de fundamento, que variam de casa para casa segundo o orixá que é dono do terreiro. No Axé Opô Afonjá, terreiro consagrado a Xangô, o toque de fundamento mais importante é o alujá, enquanto no Gantois, terreiro consagrado a Oxóssi, o toque principal é o aguerê.

Além dessas, mais estritamente ligadas ao ritual público, há um grande repertório de cantigas que são utilizadas em momentos diferentes, a saber:

- Cantigas de bori, entoadas durante o bori. Falam do ori, a cabeça;

- Cantigas de matança, que acompanham o sacrifício e falam sobre o que acontece e sobre o tempero a ser utilizado;

- Cantigas do padê ${ }^{28}$, essas falam de Exu e de suas oferendas, das Iá Mi Oxorongá, dos ancestrais e, sobretudo, dos essa, os velhos que participaram diretamente da fundação dos primeiros terreiros da nação queto;

- Cantigas de folha, que falam dos tipos diferentes de folhas utilizadas. São entoadas em alguns dias especiais da iniciação;

- Cantigas de Iaô, que são executadas no barracão na hora da saída das iaôs e são de grande fundamento;

- As Rezas, que são cantadas antes da festa do orixá na sua casa ou no ossé, às vezes têm um tom quase de choro ou lamento e são entoadas em posição agachada, como expressão de respeito aos ancestrais;

- Cantigas de axexê, que são executadas ao longo dos ritos fúnebres.

\footnotetext{
${ }^{127}$ Essa palavra significa que ele pode ir embora.

${ }^{128}$ Esse ritual foi pesquisado com muita propriedade por Elbein dos Santos (1977).
} 
Há, ainda, outras cantigas que exercem uma função dentro do ritual como a de entrada, de comida ou nas procissões, como nas festas de Oxalá, Oxum, Iamassê, ou no ipeté. Há também as de sotaque, que fazem alusões às pessoas presentes e eram muito usuais antigamente. Agora são utilizadas algumas palavras poucas vezes, ${ }^{129}$.

Um repertório específico é aquele das rodas, que são entoadas somente para alguns orixás: Xangô, Obá, Oxalá, Oxóssi. São seqüenciais, fixas de três até doze cantigas, entoadas nas grandes festas. Os fiéis ficam voltados todos para o centro do barracão e as coreografias são bastante diferentes.

Nem todas as cantigas são dançadas, mas aquelas como a de folhas ou a das rezas mostram uma atitude postural específica ou alguma gestualidade particular. Há também um estilo de canto, como me explicaram. As cantigas, em função do ritual, podem ser "esticadas", sendo as palavras pronunciadas numa espécie de virtuosismo toda "coladinha".

Cada orixá tem um ritmo próprio, especial e particular, que o caracteriza e o individualiza, ou seja, não simplesmente uma música que descreve a personalidade do orixá, mas que cria a energia da divindade, pois faz parte de um ritual cuja finalidade é chamar o orixá. Além dos ritmos, há também, para cada orixá, um repertório de cantos próprios. Geralmente os ritmos corridos, mais rápidos, são característicos das divindades jovens ou guerreiras (como Oiá-Iansã ou Ogum), enquanto os orixá velhos (como Oxalá ou Nanã) são manifestados num ritmo mais lento e tranqüilo.

O ritmo-identidade de Xangô é o alujá, forte e corrido. Mas toca-se também o batá, que indica nobreza. Iemanjá possui o jincá, que significa "ombros" e indica danças reais e que estimulam respeito, são de caráter muito lento. Já o ijexá, que representa Oxum, é alegre e festeiro. O $i l u^{130}$, o quebra-pratos, é o ritmo específico de Oiá, é rápido e agressivo como a deusa. O compassado e altivo aguerê é de Oxóssi, enquanto Oxalá é manifestado pelo ibi, lento e pesado. O sató é de Nana, o savalu de Oxumarê, o opanijé de Omulu. Essas três últimas divindades, que são do grupo jeje, possuem ritmos de caráter lento e pesado, como se algo os estivesse atirando para o chão.

Há, ainda, alguns ritmos que são de todos os orixás e que cumprem funções especificas no ritual. De acordo com as entrevistas, parece que alguns ritmos são utilizados para ligar os orixás que têm uma relação mitológica entre si. O vassi, por exemplo, é utilizado para chamar as divindades e é a base das cantigas de vários orixás que se diferenciam conforme sua particular marcação no rum, diferente para cada orixá: Ogum, Nanã, Oxum, Oxóssi, Oxumarê, Obá, Euá, Obá, Oxalá. Porém, de acordo com as características dos orixás, muda-se o canto, tornando-o mais corrido ou mais lento.

O ijexá, apesar de ser um toque de Oxum, é também o de Logum Edé, filho de Oxóssi e Oxum, e é utilizado também para Oiá, Ossaim, Ogum e para o velho Oxalá, Oxalufã.

\footnotetext{
${ }^{129}$ Existe porém uma maneira de falar típica do candomblé de difícil compreensão pra quem é de fora.

${ }^{130}$ No Gantois é chamado de darô.
} 
O adarrum ou giramundo, ligado a nação jeje - e assim chamado porque "todo mundo fica atordoado" —, não é tocado no Axé Opô Afonjá, mas encontra-se no terreiro de Oxumarê e no do Cobre.

O batá também é tocado para Xangô, Nanã, Oxum, Oxalá, Odudua. Por exemplo, ao longo de um ritual pode acontecer de um mesmo ritmo ser "encarreirado", isto é, ligeiro, no sentido em que a percussão se torna mais rápida, dobra, aumenta a sua intensidade, e a velocidade do toque passa a depender do orixá.

$\mathrm{Na}$ festa da Casa Branca, em homenagem a Oiá, observei que Iemanjá estava dançando na frente de Xangô e, de repente, ele - que a estava acompanhando - passou à sua frente, e o ritmo mudou ligeiramente de intensidade, porque, conforme um informante, não houve mudança de velocidade no tempo, no ritmo ou no som, mas uma intensificação da parte rítmica que é dirigida pelo tocador.

\subsection{O transe ritual}

Conforme a pesquisa e o que já foi anteriormente exposto sobre a fenomenologia do transe antes da feitura, tentarei descrever o transe no seu "módulo corêutico-musical", que significa uma técnica protetora, num quadro mágico-religioso ou, ainda, "proteção da crise através de modelos de gestos, de sons, de figuras, de ritmos e de melodias" (Carpitella apud De Martino, 1994: 335). Mas, sobretudo, significa uma fidelidade cultural a tais modelos, que funcionam como instrumentos de evocação e de controle socialmente admitidos e operantes cada vez que se delineia a crise do "tarantismo". Essa análise me pareceu adaptável ao rito do candomblé onde se verifica situações bem parecidas com a interação do módulo corêuticomusical do tarantismo.

Crise $^{131}$, ritmo, dança e resolução no transe estão intimamente ligados e em conexão orgânica, pois as sensações produzidas pela aproximação do orixá são superadas no transe e na dança. Há uma profunda reciprocidade entre os sons e o chamado dos deuses, porque a filha-desanto pede os "ritmos" e, por outro lado, os ritmos podem desencadear uma crise latente e "chamar" definitivamente o santo.

Há rituais preliminares que devem ser realizados para que o transe ocorra no ritual noturno, como a matança de animais oferecidos em sacrifício ao orixá homenageado; o fato de a fiel ser filha do orixá para o qual foi organizada a festa; o fato da mesma ter sido iniciada a pouco tempo, etc. Toda essa preparação propicia a atmosfera na qual, provavelmente, irá acontecer a possessão.

As filhas-de-santo, todavia, têm medo do estado de santo, pois as sensações da chegada do orixá nem sempre são tranqüilas. Desenvolve-se um certo mal-estar que, ao provocar o medo de ser possuída, leva a fiel a uma certa expectativa, ampliada pelo fato de que todas as

\footnotetext{
${ }^{131}$ Entende-se por crise os momentos iniciais da aproximação da divindade, que provocam sensações traumáticas em nível psicológico e corporal, conforme as entrevistas das filhas-de-santo.
} 
sacerdotisas iniciadas devem continuar a dançar na roda. Enquanto isso, as abiãs são obrigadas a sair da roda, pois lhes seria perigosa a aproximação do orixá, uma vez que elas ainda não foram preparadas para isso. Saem, também, as sacerdotisas cujo orixá não tem nada a ver com o dono da festa, fato raro porque quase todos têm a ver um com o outro. Por outro lado, há as ebômis, mais velhas por idade "no santo", que têm menos possibilidade de caírem possuídas pelos seus orixás, pois a freqüência do transe diminui com a idade.

O medo do estado de santo é verdadeiramente muito grande, pois as sensações são dramáticas e nem sempre a "caída" é desejada. Conforme um nosso informante, no entanto, "se o santo quer, ele te pega em qualquer lugar!".

Os módulos rítmicos são estritamente ligados aos corêuticos, como se os toques chamassem energicamente para a procura de uma "gestualidade" organizada ritmicamente. Assim, fica difícil diversificar as várias partes: danças, ritmos, cores, enfeites, roupas etc., pois tudo está interligado numa única semântica.

Se por acaso, como já disseram no Axé, "A gente canta, canta e o santo não vem!", pode ser que seja utilizado um dos instrumentos de fundamento, como o xere - chocalho feito de cabaça ou de cobre que se agita para Xangô - ou um tipo de campainha que, tocada perto da cabeça da iaô, provoca uma manifestação imediata, pois o som desses instrumentos atraem os orixás, porque lhes são agradáveis, sempre segundo as nossas informantes.

A função dessa campainha ficou clara para mim por ocasião de uma festa no Axé Aganju, em Lauro de Freitas, quando um pai-de-santo se aproximou com a campainha de uma filha-desanto que se mantinha a rodopiar mas sem estar completamente possuída, e tocou perto de seu ouvido, e imediatamente, a moça "caiu" no santo.

No ritual público a música tem, portanto, a função evidente de chamar o orixá e assim promover o estado de santo. O conhecimento espiritual dessas cantigas e toque de fundamento é apreendido previamente durante a iniciação, em momentos especiais. Estas cantigas que obrigam baseiam-se numa tradição transmitida no terreiro, tendo cada casa de candomblé uma tradição própria.

Resumindo: há algumas cantigas que obrigam que têm efeito sobre todas as filhas-desanto, independentemente de seu orixá, já outras agem sobre determinadas famílias de orixá como, por exemplo, uma cantiga entoada só nas festas de Oxalá com efeito restrito a suas filhas, ou outra para as filhas de Oxóssi, Oiá-iansã e as aiabás ${ }^{132}$ etc.

Mas além das cantigas que obrigam há também outras que têm um efeito mais individual em momentos chamados de "ensaios", que têm lugar antes da iniciação. Os alabês desenvolvem uma ampla exploração musical, junto à mãe-de-santo ou às mais velhas ebômis, utilizando todo o repertório das cantigas, procurando descobrir a cantiga na qual o corpo da iniciada responda e manifeste o seu orixá. Quando isso acontece, encontra-se o ritmo, a identidade mítica individual da nova sacerdotisa, que a acompanhará ao longo de toda a sua vida. Essas cantigas, porém, são diferentes das de rum, que também contam sobre o fundamento.

\footnotetext{
${ }^{132}$ As aiabás são os orixás femininos. Aiabá significa rainha em iorubá (aiá = esposa + obá $=$ rei, mulher do rei).
} 
Essa "cantiga pessoal" exerce um grande poder sobre a filha-de-santo, por isso, ela deve guardar, zelosamente e em segredo, a identidade de tal canção, sendo essa a sua personalidade sonora mais profunda.

Então, podemos finalizar dizendo que o transe no ritual público do candomblé acontece em relação com as práticas rituais estabelecidas com antecedência, as quais se desenvolvem segundo um padrão tradicional. Conforme Bastide (1976: 117), o transe afro-americano é uma linguagem (motora e vocal) que tem um código interno, enquanto que para o Ocidente é a recusa de uma linguagem, é uma fuga da realidade.

Desse modo, os papéis desempenhados pela música assim que o transe acontece são os seguintes:

Cantigas que obrigam (aquelas de efeito geral),

Cantigas que obrigam pessoal (efeito individualizado),

Instrumentos de fundamento.

Há também no repertório outras cantigas que mexem com o lado emocional e afetivo, como as:

Cantigas de fundamento, que, contando sobre as ligações míticas, chama um determinado orixá

Cantiga de Oxalá e Iemanjá que são especiais porque ambos os orixás são vistos como pai e mãe de todos os demais orixás. Essas cantigas produzem grande efeito emocional em todos os orixás e filhas e filhos-de-santo, pois diz-se no candomblé que nenhum orixá pode resistir ao apelo da mãe ou do pai.

Concluo afirmando que, nesse contexto, a música não é um simples evento, mas é "música para ser". A música e o mundo estão presentes numa única semântica. A música tem um efeito desencadeador do transe no ritual público. Na África Ocidental, como no candomblé, o tambor está associado aos espíritos e mostra uma correspondência entre a energia espiritual e o ritmo. 


\section{Capítulo 8:}

\section{A DANÇA DAS AIABÁS E O CORPO COMO EXPERIÊNCIA SOCIAL E RITUAL}

\subsection{A dança africana}

A dança no candomblé tem uma clara origem africana. Tudo o que acontece, inclusive nas danças de rua na Bahia, aponta para isso: a importância do grupo, o uso do corpo, a gestualidade, a postura dos pés, a relação com a terra, a pulsação rítmica que dá origem ao movimento, a repetição dos gestos, tudo isso nos leva a perceber a clara ligação das danças do candomblé com as africanas ocidentais.

Já Gorrer (1981) afirmava que a dança africana põe o corpo todo em movimento por meio de uma dinâmica que encontra sua força propulsiva em um ponto abaixo da bacia, perto do osso sagrado. Essa pulsação rítmica funciona como se fosse absorvida para esse ponto, que liga a parte alta do tronco do corpo humano à parte baixa (as pernas e os pés ${ }^{133}$ ).

É claramente observável o uso das articulações, que são amplamente utilizadas, como as dos joelhos, sempre dobrados, ou as dos cotovelos. Assim, o movimento torna-se amplo, por exemplo, o do braço (que parte da articulação do ombro) ou o da perna (que se origina nos quadris). A ampliação do movimento encontra-se em oposição a algo de interior que está imóvel, percebe-se isso pelo olhar dos dançarinos, não só na dança de transe, mas também nas danças de rua, como o samba de roda, nos quais os dançarinos concentram-se interiormente para poder

\footnotetext{
133 Esse movimento é claramente observável na dança de Oxum, mas também nas danças de rua onde foi transformado numa rapidíssima oscilação da bacia.
} 
movimentar o corpo todo e, desse modo, deixar livre o movimento da coluna, que se manifesta com aquele típico tremor do corpo. A expressão facial parece tornar-se uma máscara, muita vezes observamos como única expressão um sorriso "vazio", que sublinha uma felicidade e uma satisfação internas que deixam a pessoa plena e que nos contextos rituais leva ao encontro com o sagrado (entrevista com Isaura Oliveira, 1998; Fanta Touré, 1998-1999; Keno, 2000 ${ }^{134}$ ).

Quase sempre a dança, seja a de uma festa profana seja religiosa, acontece num contexto lúdico e social, ela é uma forma de estar junto, de compartilhar algo. A emoção e o relaxamento que as pessoas experimentam depois, permitem uma comunicação afetiva e direta e não mental.

Outro fato decisivo é a comunicação com a terra, com a mãe terra que nos sustenta, que nos abrange. (Courlander, 1981). Os pés são quase sempre nus e batem o solo com toda a planta, num movimento de ida e volta que é transmitido ao corpo inteiro. $O$ fato de bater com o pé todo torna-se algo de grande importância, pois nos fala da vida, da experiência que deve ser aqui e agora, de não termos que fugir para um outro mundo, um mundo de felicidade, como mostra o balé clássico com os pés que dançam apoiados na ponta e movimentos que nos inspiram leveza e quase um mundo de visões. Pelo contrário, na dança de origem africana os movimentos do corpo nos falam da vida cotidiana, do trabalho dos homens e das mulheres, do ninar as crianças, do caçar, enfim, da vida voltada para aquilo que ela é.

Não podemos esquecer que o fato de dançar ritmicamente constrói o tempo, como afirma Duplan, o ritmo organiza e mede o tempo que é um tempo a ser vivido e possuído pelo dançarino. Isso resulta numa organização interior da pessoa que, levada pelas muitas tarefas cotidianas, consegue vivenciar o próprio trabalho com valor e, experimentando-o, entrar na repetição do gesto, do movimento até possui-lo. Outra vez retomarei o conceito da repetição: a repetição do gesto nos permite entrar no movimento, de vivenciá-lo profundamente no nosso corpo a fim de encarná-lo em nós. A polaridade do homem é classicamente percebida pelo ritmo de seu andar e pelo movimento do coração, esse movimento de contração e relaxamento é também fundamental, pois a polaridade é vivida até se unir e confundir em si no transe, para o qual a respiração, o ritmo e o movimento interligam-se estritamente num todo que é a energia do orixá.

As danças populares são feitas em círculo e essa forma nos leva a uma idéia de harmonia e equilíbrio e à participação de todos. Nas danças de candomblé temos um uso mais complexo do espaço na forma de círculo, por exemplo, na danças dos orixás, utilizam-se as linhas retas e as diagonais, como se o círculo tivesse sido explodido para permitir que os deuses saiam e se expressem para voltar à união de todos na dança da roda, no final do ritual.

Tudo isso para dizer que a dança na África e nas tradições da diáspora é uma forma de conhecimento, que não é apenas mental, mas passa através da experiência dos sentidos e das emoções, educadas através da dança e do ritmo.

Finalizamos com as palavras de Seghor quando escreveu: "Je dance l'autre, donc je suis", que explica, muito claramente, o que é a dança para o africano: dançando, conseguem se

\footnotetext{
${ }^{134}$ Série de entrevistas com dançarinos profissionais baianos e com Fanta Touré, dançarina senegalesa, do balé folclórico de Dakar.
} 
identificar com as pessoas, com a natureza, com o seu grupo, e, por meio da comunicação com o outro, sentem que são, que existem, que vivem e percebem seus limites e aqueles dos outros.

\subsubsection{A atitude do corpo e a interpretação estética nativa da dança no candomblé}

Falei sobre esse assunto com várias pessoas, além daquelas de minha pesquisa, ligadas ao candomblé e, então, consegui entender alguns conceitos filosóficos dessa tradição.

Começo com relatar a importância de uma postura física balanceada e moderada na gestualidade do corpo e na dança. Segundo minhas informantes, na vida a pessoa deve tentar alcançar um equilíbrio entre o positivo e o negativo. A ebômi Elvira, com a qual falei muito sobre esse assunto, disse:

"Existe sempre o positivo e o negativo numa situação. O bem e o mal são amigos. É a gente que tem que relacionar os dois."

Não há situações completamente negativas nem completamente positivas, e, se um dos dois aspectos prevalece, significa que há algo de errado e que o equilíbrio deve ser alcançado outra vez, sabendo-se de antemão, porém, que a vida é uma alternância de momentos e cabe ao ser humano se equilibrar.

Isso também ocorre na estética da dança. Lembramos de uma fiel de Oiá-Iansã - para mim, esplendorosa dançarina - que movimentava-se no terreiro como uma borboleta, tamanha era a velocidade e a leveza que o orixá dessa sacerdotisa alcançava no transe, porém ela fazia movimentos fortes demais - como uma excessiva soltura no movimento dos ombros e do rosto — e desarticulados, que não expressavam a idéia de equilíbrio. Naquela ocasião foi feita uma comparação com a dança de uma outra Oiá, muito mais compassada no sentido de expressar, inclusive em seus movimentos rituais, uma idéia de equilíbrio e simetria. Temos como ideal de simetria na saudação ritual o dobale ou icá, no qual as sacerdotisas e os homens dobram-se na frente dos mais velhos com posições equilibradas, simétricas e proporcionais.

Como já relatamos anteriormente, o conceito de belo é algo que merece ser discutido. No candomblé ele não é apenas algo ligado à aparência exterior, mas deve corresponder a uma beleza interna, do caráter e também da personalidade. Sempre segundo ebômi Elvira:

"A gente acha de conhecer e depois de repente, eis acontece algo e a gente vê outras coisas das pessoas. Ai depois a gente vira desconfiada com tudo!. As pessoas podem ser bonitas, ter uma postura amável e de repente a gente percebe que é toda uma construção.".

A beleza externa do corpo, portanto, deve corresponder a algo de interno, uma graciosidade que só um corpo espiritualizado, dizia Lowen (1991), alcança quando consegue equilibrar o lado mental, o lado emocional e o lado corporal. Isso acontece quando um fiel além de estar em ordem com suas obrigações, consegue ter uma posição moral na sociedade, apesar das pessoas serem aceitas também com suas idiossincrasias pessoais. Mas sem ter um bom caráter a beleza não serve. 
A comunicação corporal é altamente importante, às vezes mais do que a comunicação verbal. No candomblé existe toda uma etiqueta e uma aprendizagem que a abiã deve incorporar a fim de poder entender o comportamento das pessoas e como se posicionar.

Existe toda uma gramática da expressão dos olhos e do rosto que parece um verdadeiro código secreto. Para tal fim lembro, numa conversa com a informante supracitada, da importância de se ficar calado e de saber observar o que acontece: ela, para destacar e finalizar com suas palavras, fez um movimento na frente da boca e depois pôs sua mão fechada debaixo do corpo (estava sentada) e, finalmente, disse: "observe e fica em cima! ${ }^{135 " .}$

Com o tempo, as pessoas no candomblé tornam-se altamente perceptíveis e sensíveis aos sinais do corpo e à compreensão da personalidade das pessoas ${ }^{136}$. O corpo e o seu código comportamental, então, seriam a manifestação física de cada "pessoa", pois aprende a produzir sinais codificados ao longo da aprendizagem, que nos mostram aquilo que uma pessoa é e pensa ser.

Ressalto também o espaço e a proxêmica ${ }^{137}$ que põem as pessoas em relação constante no cotidiano como, por exemplo, na preparação das festas da chegada dos orixás, todo mundo está próximo, está em contato corporal, como se o sagrado fosse um dos tantos aspectos do real até chegar aquele belíssimo gesto que os orixás doam às pessoas, quando abraçam o público, muitas vezes pessoas desconhecidas, como também recebi e já vi acontecer em várias festas. No começo do ritual as distância entre as pessoas é maior e nos mostra a diferença hierárquica, quanto aos orixás, apesar de chegarem entre as pessoas, estão de um lado distante delas para mais tarde, no final do rito, se aproximarem das outras filhas-de-santo e do público.

A comunicação visual é extremamente eloqüente: a expressão do rosto deve ser calma e tranqüila e estar de acordo com o resto do corpo. Existe toda uma ênfase na procura e manifestação de uma calma interior em comparação com uma movimentação externa. Thompson ( 1974) refere-se à estética iorubá como uma estética da frieza para sublinhar essa calma interior.

\subsubsection{A dança do cosmo}

Segundo a filosofia do candomblé o universo é dinâmico e ao manter-se em movimento ele está em equilíbrio, em harmonia. A dança é o testemunho mais concreto e expressivo desse ritmo universal. A vida faz parte desse processo rítmico e dinâmico de criação e destruição, de morte e renascimento, expresso no ritmo das danças dos orixás, que simbolizam as energias da natureza nesse eterno e alterno ritmo, que continua em ciclos infinitos.

\footnotetext{
${ }^{135}$ Foi muito difícil para mim entender logo o que ela queria nos dizer e somente com a intervenção de uma outra pessoa é que compreendi que o "ficar em cima" significava não desperdiçar o que nos foi ensinado.

${ }^{136}$ Merece ser acrescentado que anos atrás foi desenvolvida uma pesquisa compartilhada por uma equipe de psicodramatistas, psicanalistas e mães-de-santo na Bahia. Foram aplicados testes das manchas de Rorchach a grupos de pessoas de várias área e classes sociais. Verificou-se que os terapeutas precisavam de um tempo muito maior do que as mães-de-santo (que jogam búzios) para definir o perfil psíquico das mesmas pessoas (Salvador, BA, 1990).

${ }^{137}$ A proxêmica, conhecida também como a ciência dos códigos do espaço, é fundamentada nas distâncias entre as pessoas no espaço (Hall, 1968).
} 
Os rituais do candomblé podem ser equiparados a uma cosmogonia na qual a cada ano se repete o começo do universo e o papel que cada orixá, as energias da natureza, é chamado a desempenhar, ou seja, cada festa chama a energia do orixá para se manifestar - depois de ter chamado as outras para reorganizar o universo - na sociedade a qual pertence e na fiel que será possuída.

Todos os anos têm um ciclo ritual novo, como no mito do eterno retorno com o papel de Oxalá, o pai de todos, vivos e mortos; conforme Eliade (1969: 33):

"... a repetição do ato cosmogônico não consiste tanto numa repetição dos processos vitais, mas numa verdadeira e própria criação dos mesmos processos através da repetição ritual daquele acontecimento primordial, arquetípico, que em 'illo tempore', gerou a mesma vida. Existe um tempo mítico e primordial no qual tudo já aconteceu, um tempo puro que se identifica com o instante da criação".

E, continuando:

"O homem não faz mais que repetir o ato da criação: o seu calendário comemora no espaço de um ano todas as fases cosmogônicas que tem lugar ab origine". (idem, ibidem)

As danças, dessa maneira, contam como cada energia (cósmica) dos orixás desenvolve um papel em si mesma: os orixás femininos, as aiabás, seduzem, procriam, preparam a comida, cuidam das crianças e orientam-nas; os orixás masculinos procuram a comida, são guerreiros, são caçadores ou conhecedores dos encantos das ervas; enfim, cada um tem seu papel. Por isso, no ritual, os fiéis revivem o momento originário da criação e, agindo assim, exorcizam a morte, o sofrimento, e recebem novas energias.

A angústia de não sobreviver à caducidade da vida e à passagem do tempo é tão antiga quanto o mundo, e o ser humano sempre tentou exorcizá-la através de danças rituais, nas quais o ser humano acredita sair da esfera do tempo e entrar em contato com a essência primordial, na qual não há o correr do tempo e as dimensões conhecidas do espaço. Lévi-Strauss (1971: 590) destaca a procura do ser humano de parar o tempo no ritual e de celebrá-lo dançando, de não deixá-lo decorrer em sua passagem, acalmando, desse modo, a angústia existencial. Dançando, o ser humano ritualiza a vitória sobre o tempo que passa e a comemora para revivê-la e para continuar a viver eternamente tornando-se, assim, ancestral. As danças das divindades tornamse, portanto, a síntese do ritmo humano (do nascimento e da morte) e dos ciclos cósmicos da criação e da destruição. Elas tornam-se, então, símbolos do binômio espaço-tempo, que mede a história do mundo, e das energias que se manifestam fora do tempo.

No candomblé há a consciência de uma unidade entre todos os seres e o cosmo, e sabe-se também que os movimentos do corpo nas danças de transe transcendem a pura gestualidade, inserindo-se no movimento do universo e recuperando energia. Para o candomblé, portanto, as danças são fundamentais, pois imitando e transcendendo, fundam-se no movimento das energias naturais. Entende-se assim o porquê da repetição e da procura de perfeição dos movimentos, sendo uma das técnicas para a ligação com essas energias.

A dança tem a tarefa de acompanhar o ser humano no caminho iniciático e também na metamorfose do transe, necessária para encontrar o sagrado. O transe, conforme já dissemos, é 
uma experiência difícil de se exprimir com palavras, pois é uma transformação interna, que pode ser manifestada apenas pelo movimento do corpo que se torna fluido e de uma maior grandeza gestual. A religião usa muito as artes e a comunicação não verbal, pois exprimem sensualmente mensagens profundas que seriam impossíveis de expressar com palavras. Daí a importância da arte ritual como mensageira da alma humana. Langer (1953: 40) explica isso quando diz: "a arte é a criação de formas que simbolizam os sentimentos humanos".

Mas as danças também representam a vida do orixá e as suas características. Para Bastide (1978: 22):

"A dança constitui a evocação de alguns episódios da história da divindade que são fragmentos do mito e o mito tem que ser representado ao mesmo tempo que contado para adquirir todo o poder evocador".

Assim, a dança pode ser considerada uma forma de literatura oral, conforme Bastide (1978) que já tinha evidenciado o seu caráter de conto.

Cada orixá tem um padrão que é aprendido antes da iniciação e no roncó, mas existe claramente uma liberdade para expressar a própria criatividade e a "qualidade" do orixá. Finalizo com as palavras de Susan Langer (1980: 178):

"O movimento corporal é bem real, mas o que torna o gesto emotivo é a sua origem espontânea, no que Laban chama de 'movimento-pensamento-sentimento".

Dessa maneira, é possível entendermos a importância do gesto, que não é mera repetição, mas a força da espontaneidade que está dentro de nós.

Toda a liturgia no ritual do candomblé apóia-se na música e na dança; enquanto a primeira é o fio que identifica e liga os vários momentos do ritual, a dança é a comunicação. Assim, para entendermos o desenvolvimento da cerimônia e quais mensagens estão passando os orixás, e para quem, é preciso ter conhecimento dos ritmos e das cantigas que ligam entre si as partes do ritual.

\subsection{As danças no ritual público do candomblé}

Nos rituais de candomblé a função da dança é múltipla: é mimética e litúrgica. Quando a defino como mimética entendo que ela imita os movimentos, os atos do orixá. Mas ela também é litúrgica porque sinaliza e liga os vários momentos do ritual até chegar a expressar a manifestação mística do orixá nos momentos das danças de transe, quando forma e conteúdo juntam-se numa única dimensão: a do orixá. Por um determinado tempo, os limites do corpo são ultrapassados e a energia do orixá se expande na dança através de um movimento bem mais fluido e amplo, através de uma ocupação total do espaço e do tempo.

Como já observei acima, a dança sagrada expressa a própria energia da natureza, materializada no corpo da filha-de-santo em transe. Desse modo, por exemplo, como Oiá-Iansã representa o vento, toda a sua gestualidade e movimento expressam não só mimeticamente, mas também sensualmente a instabilidade, o desequilíbrio, a fúria majestosa do vento que, conforme 
sugeriu uma informante, "é onipresente e pode estar tanto embaixo, quanto em cima. Tanto pode ser leve, como pode virar uma tempestade que tudo abate e derruba".

O sentido das danças sagradas é o de transmitir - com o movimento do corpo - que a transformação não é só matéria, mas energia sagrada, vibração dos orixás. Quero sublinhar que, tratando-se de danças religiosas, os movimentos originam-se devido a uma longa aprendizagem seja como abiã, seja no roncó. As danças aqui tornam-se um modo de se ligar ao próprio orixá e, portanto, são quase técnicas de meditação profunda, na qual os movimentos ligados à respiração, numa contínua contração e relaxamento, mobilizam a energia do orixá e o apresentam.

As danças rituais no candomblé expressam uma idéia de grande concentração e porte, muito longínqua das idéias que usualmente as pessoas têm da dança de transe. Os movimentos dos orixás parecem de fácil aprendizagem, mas isso não é verdade, uma vez que às vezes pequenas mudanças acontecem na movimentação dos braços ou na velocidade do tempo nos passos básicos, e isso sem contar com a interpretação, porque cada orixá tem coreografias próprias, estritamente interligadas às cantigas. Estas últimas, pelo fato de serem perpetuadas por pessoas cuja cultura é oral, às vezes são esquecidas ou sofrem mudanças em algumas palavras, o sentido emocional delas, entretanto, permanece o mesmo.

\subsubsection{Coreografias}

Tratarei aqui das danças na festa pública do candomblé. Em sua primeira parte, são reconhecíveis dois tipos de dança.

No começo da festa, temos o xirê (literalmente "brincar"), onde se canta para todos os orixás um mínimo de três cantigas, acompanhadas pelas danças. Cada orixá possui cantigas e gestualidade particulares, pertencentes só a ele. Essas danças são previsíveis, porque são executadas ainda em estado consciente e seguem um padrão fixo que depende do orixá dono da festa. Não se dança para Exu, pois ele foi homenageado no padê que ocorreu à tarde.

Todas as filhas e os filhos-de-santo participam dessas danças, formando, no início, um grande círculo, chamado a roda. Essa primeira parte da festa pode ser considerada uma cosmovisão: todas as energias da natureza são chamadas a descer a fim de restabelecer o antigo equilíbrio entre as energias da natureza e os homens. Em geral, os fiéis dançam um atrás do outro, seguindo um padrão hierárquico, em sentido anti-horário.

Quando se dança o xirê, segundo Oliveira ${ }^{138}$ (1998):

"(...) os movimentos são de dimensão pequena como se fosse só um esboço do passo, chamam-se 'dançar pequenino', pois são movimentos de dimensão pequena e servem para as sacerdotisas se concentrarem e se prepararem para receber o orixá."

Como um segundo tipo, temos as que são executadas nos toques que chamam as divindades. No Axé Opô Afonjá, todas as sacerdotisas se dispõem na roda de Xangôo ${ }^{139}$ olhando

${ }^{138}$ Comunicação oral. 
para o centro do barracão e concentrando-se nessa direção. Nesse lugar está colocado o fundamento da casa, a raiz material da casa. Em pouco tempo, após terem afastado as abiãs, começam as incorporações.

Em terceiro lugar, depois dessas incorporações, quando todos os orixás já estão manifestados, as divindades dançam a coreografia chamada primeira de dar rum, que as apresenta ao público. Esse tipo de dança é executado em estado de inconsciência, porque os fiéis estão em transe, é o próprio orixá que dança nesse momento, seguindo e dialogando com o ritmo sagrado dos tambores. Nessa parte, apesar de haver um padrão de desenvolvimento ritual fixo, o andamento da festa é imprevisível porque não se sabe exatamente quais serão as coreografias, pois isso depende da vontade do orixá - conforme observei várias vezes e claramente na Casa Branca $^{140}$ - assim como das cantigas entoadas pelos fiéis presentes, da memória para lembrar as antigas cantigas e também da presença das iá-tebexê ou dos babá-tebexêe $\hat{e}^{141}$, quer dizer, das filhas ou filhos-de-santo que têm a tarefa de entoar as cantigas e de continuá-las quando os outros não se lembram mais delas. Além disso, o desenvolvimento da festa depende de outros elementos complicadíssimos, como a relação entre o orixá "dono da festa" e o da mãe-de-santo, a chegada de algum sacerdote importante - como foi o caso na festa da Oxum de Mãe Senhora (no Axé, em outubro 2000), quando inesperadamente chegou Pai Balbino de Xangô, filho espiritual de Mãe Senhora e irmão de Mãe Stella que depois de ter incorporado seu Xangô, dançando na frente da mãe-de-santo conseguiu chamá-la na dança - , mas o desenrolar do ritual pode ter um outro padrão, tendo-se em conta também as relações entre os orixás.

Assim, por exemplo, numa cerimônia para Oiá-Iansã, assiste-se às danças típicas: a da guerra, a da sedução (como mãe ou rainha dos Eguns) e às coreografias ligadas a outros orixás, como Ogum, Xangô, Oxóssi, seus maridos. Na parte das danças de transe, os orixás são chamados a manifestarem-se em todas as suas formas possíveis e também junto com as outras forças da natureza. O orixá mostra ao público sua história mitológica, redistribuindo a energia vital, axé, e trazendo o mundo sagrado de volta ao cotidiano.

Quando os orixás se apresentam, entram no barracão em fila, seguindo a hierarquia dos orixás e a dos mais velhos no santo; à frente vem sempre Ogum, aquele que abre o caminho, depois, as filhas mais velhas, seguidas daquelas com menos tempo de iniciação. No final, há uma coreografia de despedida, em geral igual para todos os orixás que saúdam o público, a mãe-desanto e os atabaques, restabelecendo a ordem inicial. Então, as forças da natureza chamadas a concentrar-se no espaço sagrado são espalhadas novamente e repartidas no seu locus originário.

\footnotetext{
${ }^{139}$ Lühning (1990 b: 115-116) diz: "As rodas são seqüências fixas, normalmente de três, seis ou doze cantigas que são entoadas durante o xirê, nas grandes festas. Elas contam longas histórias, relacionadas entre si, sobre a vida dos orixás. Uma característica especial da sua coreografia é que todos os participantes dançam com os rostos voltados para o centro da roda. Há roda para Xangô, Oxum, Obá, Euá, Oxóssi, Iemanjá e Oxalá. Uma vez que estes cantos são entoados muito raramente, poucas pessoas (geralmente as ebômis) dominam os complexos textos e movimentos."

${ }^{140} \mathrm{Na}$ festa de Ogum, em 2000, na casa Branca, esse orixá desceu e ficou parado. Tentaram cantar várias cantigas para ele, mas somente quando a mãe-de-santo, aproximado-se do orixá, entou a cantiga correta, Ogum finalmente dançou.

${ }^{141}$ Iá-tebexê e Babá-tebexê são os sacerdotes mais velhos no santo que puxam as cantigas.
} 
Como tentei esclarecer anteriormente, cada orixá possui cantigas, comidas, roupas litúrgicas e uma coreografia própria que se liga, numa correlação perfeita, com a música, numa síntese harmônica, ou seja, todos esses elementos inscrevem-se num universo simbólico rico e sofisticado.

Uma análise dos movimentos no ritual mostra uma gramática litúrgica fundamentada na experiência do corpo e na da possessão. Os movimentos e os ritmos sinalizam vários aspectos do ritual, por exemplo, as várias fases dele: começo, chegada dos orixás, entrada das divindades paramentadas e saída final. As danças também expressam a energia que sustenta o orixá e, por meio das cantigas, colaboram para contar episódios da história mítica e transmitir a visão-demundo do grupo. Mas, por outro lado, também os passos parecidos das divindades velhas, por exemplo, nos mostram uma sabedoria alcançada com os anos, ou, ainda, os pulos dos orixás mais novos mostram uma vitalidade mais instintiva do que uma sabedoria provada. Já os movimentos redondos de Iemanjá e Oxum nos falam da maternidade, do lado farto e fecundo das mulheres. Enfim, através da fluidez do movimento e de outros elementos narram a história pessoal da filha ou filho-de-santo e a sua experiência de fé e de cura. ${ }^{142}$.

A coreografia de algumas divindades possui alguns passos semelhantes que devem demonstrar algum tipo de relação entre elas, por exemplo, o fato de pertencerem a um mesmo elemento (água, terra, fogo, ar etc.), ou a uma mesma nação, ou uma mesma função no cosmo. Há movimentos ligados à energia dos elementos da natureza, por exemplo a água; todos os orixás femininos ligados a esse elemento têm algum movimento em comum que, contudo, é elaborado com outros movimentos ou com alguns objetos típicos de cada orixá.

Do mesmo modo há movimentos ligados aos orixás da terra (de nação jeje) — Nanã, Oxumarê e Omulu - cujas danças são mais dobradas em direção à terra, enquanto que os movimentos dos braços e das mãos são estendidos para a frente e trazidos para o lado do tronco. Os orixás da mata como Ogum, Oxóssi, Ossaim, o dono das folhas, e Oiá, o vento, andam às vezes como que procurando algo incessantemente: Ogum procura o guerreiro oponente, Oxóssi, a caça, Ossaim, as folhas. Oiá, porém traz o vento e transforma-se em búfalo: seus braços são trazidos alternadamente para a frente e para trás, com um grande empurrão dos pés que deslizam para a frente e, num segundo momento, são levantados para trás.

O rei Xangô identifica-se com gestos firmes de abrir e fechar o ângulo dos cotovelos e cerrar os punhos, desenhando movimentos abertos que abarcam as forças de seu elemento mágico, o fogo. Segundo um informante, Xangô "dança tudo aberto, ele é alegre, é feliz de estar presente, ele quer muita gente e as suas aiabás." Mas não podemos esquecer que Xangô é o orixá do raio e, portanto, sua dança característica é jogar raios para o alto e para baixo. $\mathrm{O}$ movimento dos pés é contínuo e, no contratempo, repetidamente leva um pé para a frente e dá um leve pulo para trás com os joelhos dobrados. O ritmo dos pés assemelha-se bastante, no impulso rítmico, ao de Oiá que, por ser do elemento ar em movimento, liga-se estreitamente ao fogo

\footnotetext{
${ }^{142}$ A palavra "cura" não é, nesse contexto, usada simplesmente com o significado de restabelecimento físico de alguma doença, mas num sentido mais amplo, no qual a cura implica contato com o próprio mundo do sagrado, propiciando o reequilíbrio das energias e defendendo a pessoa dos agentes externos como doenças, inimigos etc.
} 
quando dança seu ritmo característico, o ilu, chamado também de darão (no Gantois) ou, popularmente, de quebra-prato.

Os orixás da água, todos femininos (Iemanjá e Oxum), dançam com uma grande fluidez nos braços como que indicando o lado acolhedor das mulheres.

As dançam se dividem em danças que identificam o orixá como aquelas de dar o rum que significa que o orixá recém-chegado deve se conectar com o rum (o tambor mais importante que seria a voz do orixá). Dar o rum significa dar o fundamento, a base do orixá, e, portanto, são os pés que devem se conectar com o rum. É como se apenas o ritmo, sem o canto, significasse a personalidade do orixá, o fundamento dele, enquanto que as cantigas contam as histórias mitológicas.

O alabê, o atabaque e o orixá devem estar interligados como se participassem de um mesmo campo energético para poderem se ouvir e se falar. Os três devem estar presentes e firmes na situação, concentrando-se naquilo que estão fazendo no momento. É uma tensão muito grande a que se desenvolve entre o alabê e o orixá, pois um depende do outro, indissoluvelmente. Forma-se, então, uma corrente que não pode-se ser quebrada. Por isso é que se usa mudar de tocador ao longo do ritual, pois o desperdício de energia é muito grande. Parece quase que a música sustenta o orixá, como pude perceber numa festa para Xangô na Casa Branca, em novembro de 1999, quando uma filha-de-santo de Omulu dançava, evidentemente, suspensa e como que dentro de uma faixa da música. A postura do corpo dessa filha-de-santo me impressionou bastante porque parecia estar com o corpo firme, como que encaixado, só os braços se estendiam e se dobravam num ritmo fora do tempo e do espaço. Os alabês tocavam sempre com mais ânimo. Os que puxavam as cantigas trocavam-se numa euforia crescente e contagiante que abrangia o público, que batia as mãos no acompanhamento.

E muitas vezes até mesmo o alabê executa movimentos corporais que não chegam a ser uma dança, mas que mostram claramente o acompanhamento do corpo à percussão. Sobretudo aquele que toca o rum participa corporalmente de sua música. Os braços são lançados para o alto e o corpo todo segue o ritmo da percussão. "Mas é sobretudo no jeje que a gente toca assim, fazendo um montão de gatice", me disse um informante.

O olhar é fixo, em direção aos pés do orixá, pronto para perceber as variações na dança ou alguma mensagem. Muita vezes, um de meus informantes alabês não cansava de me dizer: "Fico todo arrepiado quando toco para Oiá", deixando entender, assim, sua forte ligação com Oiá pelo fato de ser filho de Xangô, mas também as fortes sensações, emoções que os sacerdotes do candomblé experimentam ao longo do ritual. Isso indica, ainda, que as percussões passam do ouvido ao corpo inteiro, como se entrassem nos ossos e gerassem uma influência emotiva e energética no corpo. 


\subsection{O espaço sagrado da dança}

Toda a roça ${ }^{143}$ do candomblé é considerada lugar sagrado. No momento em que o fiel entra no terreiro, entra num lugar mágico-sagrado. Logo na entrada há o assentamento de um tipo especial de Exu que defende a comunidade e todos os seus filhos. O mundo de fora é perigoso e cheio de dificuldades. Dentro, existem várias provas a serem superadas, mas as filhas-de-santo encontram aliados na luta pela sobrevivência e no caminho místico-religioso. No terreiro há vários lugares sagrados, mais ou menos perigosos segundo a energia que transmitem. Por isso nem todos podem entrar nas casas dos orixás ou circular de noite nos lugares dedicados aos espíritos dos mortos. Tanto a rua, o mundo de fora da roça, quanto o próprio terreiro poderiam simbolizar uma peregrinação, um caminho iniciático, lugar de passagem para alcançar o barracão, o lugar onde as divindades se manifestam, nas cerimônias públicas.

O espaço onde acontecem as festas públicas é chamado barracão. É um salão muito amplo, onde, logo na entrada, há uma arquibancada. Do lado direito, sentam-se as mulheres e, do lado esquerdo, os homens. Na frente da entrada, é colocado o trono da Ialorixá, cujo lado direito é reservado às filhas-de-santo e as ebômis com cargo, enquanto o lado esquerdo é reservado aos obás ${ }^{144}$ de Xangô, os ministros deste orixá. No lado direito, além das mulheres, está colocada a orquestra com os três atabaques. Na sua frente ficam as famílias dos ogãs, hierarquia leiga do candomblé, ou algum convidado particular.

O fiel dança, segundo Wheatley (1983), ao redor do centro sagrado, um ponto da terra ligado ao céu por um invisível raio energético, o axis mundi. Nesse ponto estão enterrados os fundamentos $^{145}$ da casa, que também são colocados no teto, num lugar diametralmente oposto. O centro do barracão é fundamental nas religiões africanas, porque é o lugar onde a árvore mágica liga o céu à terra, conforme Davidson (1972) e Deren (1997).

Em geral, os lugares sagrados apresentam as mesmas analogias: em cima do ponto sagrado, o céu, o teto redondo e a cúpula tomam a forma da terra embaixo (que é símbolo do feminino e do espaço que contém), uma árvore sagrada na África, um obelisco ou um minarete nos países árabes (símbolos do masculino, do céu e do tempo) ligam a abóbada ao chão. Mas nem sempre essa árvore existe visivelmente. No Axé Opô Afonjá ${ }^{146}$, por exemplo, não sabemos por que motivo não há um poste central. Para Eliade (1969:26):

\footnotetext{
${ }^{143} \mathrm{O}$ termo roça está próximo do termo aldeia. É um lugar onde se cultivam as plantas e se criam os animais.

144 De acordo com Vivaldo da Costa Lima: "(...) os obás de Xangô, são os Ministros de Xangô, o grupo foi instituído formalmente no candomblé de São Gonçalo, no ano 1937, quando aquele terreiro estava sob a direção de sua primeira mãe-de-santo Eugênia Ana dos Santos. Os obás, são doze, dividem-se em duas falanges, seis do lado direito, e seis do lado esquerdo".

${ }^{145}$ Cada terreiro tem seu próprio fundamento.

${ }^{146}$ Podemos observar, em alguns terreiros de Salvador, como o do jeje Bogum e o terreiro do Cobre, na Federação, ou o mais antigo, a Casa Branca do Engenho Velho, a simbolização da árvore sagrada na forma de um poste central que liga simbolicamente o céu à terra. Em outros terreiros, como no Gantois, a coluna sagrada não existe, mas permanece a simbologia do centro do barracão.
} 
"(...) o centro da realidade absoluta, assim como todos os outros símbolos da realidade absoluta (Árvore da Vida e da Imortalidade, Fonte da Juventude etc.) encontra-se num centro. O caminho que conduz ao centro é um "caminho dificil", e isso verifica-se em todos os níveis do real: circunvoluções complicadas de um templo; peregrinações aos lugares santos (Meca, Jerusalém, etc.); peregrinações aventurosas das expedições do Velo de Ouro, da Erva da Vida; todas as dificuldades dos que procuram o caminho para $o$ "si", para o "centro" do seu ser etc."

A Criação, em toda a sua extensão, se efetuou a partir de um "centro" e por isso tudo aquilo que é fundado está no centro do mundo. A partir do centro passam dois eixos - um vertical e o outro horizontal - tempo e espaço. Segundo Wheatley existem alguns paradigmas astrobiológicos que formam a estruturação do espaço, ou seja, existe um paralelismo entre o espaço cósmico e o do ser humano, entre macrocosmo e microcosmo. O mundo dos seres humanos é construído à imagem do dos deuses e a harmonia é garantida por meio de rituais. Assim, o espaço na terra deve ser sacralizado através dos rituais.

O barracão é o lugar externo do culto, é a construção arquitetônica que foi sacralizada e que, pelo fato de deter cerimônias periódicas, torna-se um espaço sagrado. O corpo humano é o lugar interno do culto, receptáculo da divindade e, por si mesmo, sagrado. Esses dois lugares são o teatro da transformação ritual, neles o fiel deixa o mundo cotidiano e chega ao encontro tão assustador, mas tão desejado, com o divino. É somente no espaço sagrado que ele pode voltar à totalidade - sendo sustentado pelo seu grupo e pela experiência da mãe-de-santo e das ebômis e se comunicar com a divindade.

O espaço do barracão, durante o ritual, é preenchido pelos corpos das sacerdotisas, que logo se transformam em orixás. Dessa maneira, o espaço está preenchido pelos níveis dos corpos em movimento e pelas direções, que, por sua vez, são os caminhos do corpo no espaço que simbolicamente expressam as várias possibilidades de caminhar em direção ao sagrado. A divindade pode utilizar uma estrada curvilínea mais moderada (como o andar de Iemanjá), ou um caminho que prevê várias mudanças de direção (como o de Oiá ou de Ogum).

Mas há também um outro espaço, ainda mais precioso, o do interior do corpo, no qual acontece a transformação principal: a de deixar entrar o orixá. Pelo fato do corpo ser a representação do macrocosmo, a coluna vertebral simboliza a árvore sagrada, pois liga os pés ao ori, os ancestrais ao orixá, enquanto que os braços abertos mostram a ligação com o social. No momento das danças de transe, o espaço é preenchido mais "densamente" pela a energia dos orixás que o estão utilizando e ocupando em todos os níveis: alto, médio e baixo.

\subsubsection{As Formas sagradas}

As danças são executadas em coreografias no xirê ou durante a incorporação. Elas são muito diversificadas, pois há uma variedade enorme de coreografias para cada orixá, embora algumas formas se repitam para todas as divindades. Antes de descrever a dança das aiabás, chamo a atenção para os sentidos simbólicos dos desenhos de algumas coreografias pertencentes ao xirê, formas observáveis também em algumas danças dos orixás. 
A primeira de todas é a forma da roda, a antiga roda sagrada, que pode ser encontrada em várias culturas do mundo. De fato, em muitas danças extáticas - entre os indígenas norte e sulamericanos, na bacia do Mediterrâneo, nas danças asiáticas etc. - , os dançarinos rodam em torno de um centro que representa o princípio, o coração do mundo (Guénon, 1992). Este ponto representa o continuum da existência que tem a sua ordem em si mesmo. Sem forma, ele não pode ser observado diretamente nem a razão pode conhecê-lo; seu dinamismo, no entanto, se manifesta em imagens. A maneira para colhê-lo passa através dos estágios da experiência estética e da mística. (Marchianó, 1977). Podemos entender isso também no candomblé, pois as sacerdotisas rodam ao redor de um centro no qual é colocado o fundamento da casa, que é o começo, o princípio das forças daquela casa.

A forma do círculo tem uma grande importância, pois segundo Neumann (1981: 214),

"(...) a Grande Mãe é simbolizada como um grande círculo que contém a totalidade do universo, expressa um ideal de perfeição, de imutabilidade, mas também de transformação, porque em si contém os elementos masculinos e femininos".

É interessante observar que as danças extáticas rodam em sentido anti-horário, mas é difícil dar uma interpretação sobre esse fato, me foi dito apenas: "que é bom para o espírito". Confirmamos, ainda, que esse movimento, ao contrário, é feito no mundo inteiro, basta lembrarmos das danças dos súfi, entre muitas outras, pelo fato de ser um movimento centrifugo dizem que é um movimento que abre para uma outra dimensão, aquela sagrada.

Outro aspecto a ser destacado é que essas danças começam em um grande e lento círculo que vai diminuindo ao longo do ritual com rodopios, feitos durante as incorporações. Uma outra forma, encontrada em outras coreografias, é a da espiral que se mostra seja no movimento da incorporação, seja na bela dança de $\mathrm{Exu}^{147}$. Assim como o círculo é um símbolo antiqüíssimo encontrado em quase todas as culturas e também na natureza, incluindo-se a molécula do DNA - , também a espiral o é e aparece nas rotações que as filhas-de-santo fazem sobre si mesmas, quando incorporam ao longo da "performance".

A espiral é símbolo da comunicação (Santos:1977; Pelosini:1994) e desse modo, quando o orixá possui o corpo da filha-de-santo, realiza-se uma comunicação entre o homem e a divindade. Enquanto o corpo material gira sobre si mesmo, a energia do orixá penetra, girando do outro lado e entra no corpo, formando uma dupla espiral, como me foi explicado. Não é por acaso que Exu, a divindade da comunicação, rodopia desse modo, conforme as danças quando se transforma, porque ele é a própria "comunicação"148. A espiral expressa o movimento circular que, ao sair do ponto de origem, movimenta-se ao infinito, organizando o caos, como dizem os dervixes. Ela expressa a evolução a partir de um centro, simboliza a vida, porque indica o

\footnotetext{
${ }^{147}$ É muito raro ver pessoas incorporadas de Exu na Bahia, pois se alguém tem esse orixá procura-se colocar Ogum na frente, como nos foi esclarecido. Mas no Axé Opô Aganju, o pai-de-santo fez um moço de Exu. Suas danças são belíssimas sempre na forma de espiral, se abrindo de um lado e do outro.

${ }^{148}$ Comunicação neste caso não significa somente o ato de comunicar, mas também o ato de transportar, porque Exu é o próprio mensageiro e leva as oferendas aos orixás.
} 
movimento numa unidade de ordem ou, ao inverso, a permanência do ser na mobilidade. Durand (1972) sugere que simboliza a permanência do ser, através das flutuações da mudança da vida. Segundo Pelosini (1994:181):

"(...) a função simbólica das rotações helicoidais seria a de aproximar, por etapas, o homem ao infinito e juntar a terra ao céu". Essas inter-relações, entre o corpo humano (microcosmo) e o universo (macrocosmo), entre o infinitamente pequeno (microcosmo) $e$ o espaço interestelar infinitamente grande (macrocosmo), já eram, em muitos casos, conhecidas ou percebidas por civilizações do passado, que as tinham codificadas em mitos e simbolos de espiral".

A espiral poderia simbolizar, ainda, a procura do próprio espírito ao longo do difícil caminho espiritual. Partindo de um ponto firme, alcança, muitas voltas depois, o mundo do sagrado. A mesma forma encontra-se na dupla hélice do DNA, que é responsável não só pela programação da atividade celular, mas também pela hereditariedade das características genéticas e da própria evolução dos viventes: é a verdadeira quintessência da vida, é o eterno que se transmite sempre. Essa molécula é o "mensageiro" da hereditariedade biológica e das características hereditárias, do mesmo modo que Exu é o mensageiro entre os homens e as divindades. Não é ao acaso que no candomblé a espiral encontra-se no ocóto, associado a Exu, orixá que expressa a dinâmica da vida, o movimento da alma na criação e na expansão do mundo. Segundo Santos (1977: 133),

"o ocóto é uma espécie de caracol e aparece nos motivos das esculturas e como emblema entre os que fazem parte do culto de Exu. Ele consiste numa concha cônica cuja base é aberta, utilizada como um pião. $O$ ocóto representa a história ossificada do desenvolvimento do caracol e reflete a regra, segundo a qual, se deu o processo de crescimento espiritual; um crescimento constante e proporcional, uma continuidade evolutiva de ritmo regular. O ocóto simboliza um processo de crescimento. É o pião que, apoiado na ponta do cone, com um só pé, um único ponto de apoio, rola, "espiraladamente", abre-se a cada revolução mais e mais, até converter-se numa circunferência aberta para o infinito".

Exu é o princípio dinâmico da evolução, sendo um deus fálico como cultor da vida e o mensageiro entre o homem e a divindade, sem ele, nada pode ser cumprido.

\subsection{As Danças Sagradas}

As danças do candomblé são uma busca do sagrado, feita através de uma longa aprendizagem e no silêncio; elas poderiam ser equiparadas, conforme Bourguignon (1976), a uma meditação ativa, pois depois de ter sido criado o vazio, surgiu a forma, a essência do orixá. A dança de possessão, portanto, é a "exibição em ato daquilo que é evocado pela música". (Segato, 1995: 168)

Como Thompson (1974: 43) observa, 
"(...) existem valores estéticos em todas as formas de arte e de culturas africanas. Como coolness, esse conceito é explicado como uma mescla de, "composure, silence, vitality, healing and social purification" (calma, silêncio, vitalidade, saúde e purificação social).

Em análise do tarantismo no Salento, sul da Itália, Diego Carpitella ${ }^{149}$ e De Martino (1994:335), nos anos 1950-1960, observaram que:

"(...) o tarantismo manifesta-se na sua fase resolutiva e terapêutica como drama ritual corêutico-musical ${ }^{150}$, o qual tem como horizonte o mito da tarântula, aranha."

Para Carpitella, o modelo corêutico-musical serve como técnica protetora num quadro mágico-religioso, funciona como meio de proteção das crises através de modelos tradicionalizantes de gestos, sons, figuras, ritmos e melodias; significa, sobretudo, fidelidade cultural a tais modelos, que funcionam como instrumentos de evocação e de controle socialmente admitidos e operantes cada vez que se percebe a crise do tarantismo.

Com base nessas observações podemos dizer que, no candomblé, a ligação entre crise e sons é uma ligação de reciprocidade porque a crise seria "o chamado do orixá", o momento de intervalo entre o estado consciente e o de consciência alargada ${ }^{151}$, que, para poder ser resolvido, tem que permitir a descida do orixá, tem que "fazer cair" o fiel, seguindo os ritmos da música, de forma que se possa resolver "terapeuticamente ${ }^{152 "}$ a crise, manifestando-se o orixá.

As frases musicais tradicionais estão estreitamente associadas às frases corêuticas e seus ritmos pedem a exigência de movimentos ordenados. Cada orixá possui um toque que expressa a característica mais profunda de sua personalidade, a saber: para Iemanjá é o jincá; para Oxum é o ijexá; para Oiá-Iansã é o ilu e para Obá é o vassi. Nas cantigas, são relatados os vários acontecimentos e os vários caminhos da sua vida. Mas os orixás femininos também dançam outros toques, junto com outros orixás ou sozinhas.

Pedi às informantes que descrevessem os traços que identificam cada toque em referência aos orixás. Tendo uma outra compreensão, diferente da nossa em relação àquilo que é a música e a dança - não percebida como arte estética, mas como a essência do sagrado —, me respondiam sempre falando das emoções e dos humores que são despertados nelas pela própria música ou pela visão das danças, fato que levava a uma conversa repleta de mitos, sonhos, enfim, do mundo do candomblé.

Cada santo tem, um padrão de movimentos que representa sua identidade, a partir de um gesto que ele repete mimética e repetidamente. Conforme Segato (1995: 168),

\footnotetext{
${ }^{149}$ Neste livro há em apêndice vários textos, entre os quais o de Carpitella.

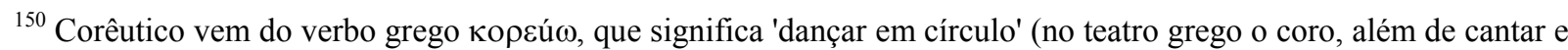
responder, dançava junto em círculo) e $\tau \varepsilon \chi \nu \eta$, que significa 'arte aprendida com a técnica'; então como resultado temos o significado de aprender uma técnica por um tipo de arte, diferente do conceito de arte pela arte.

${ }^{151}$ Uso aqui a definição do transe como "consciência alargada", porque, como propôs Grotowki, o transe permitiria uma ampliação da consciência.

${ }^{152}$ Por isso o termo 'terapêutico' é usado em lato sensu, isto é, não num sentido de cura de uma doença física, mas de resolução do 'chamado da divindade' pelo caminho religioso.
} 
"Este padrão mímico inclui um componente figurativo, onde a descrição focaliza os aspectos formais, propriamente coreográficos, e um componente não figurativo, onde o que deve ser captado é a experiência interna dos processos fisiológicos envolvidos na alternância de estados de tensão e relaxação muscular e na sua localização".

Tive a mesma idéia que a autora, ou seja, gostaria de sublinhar que o aspecto figurativo do movimento é dado pelas frases corêuticas padronizadas, mas também há um movimento em si mesmo, pois a experiência da energia do orixá pode ser vivida e aprendida apenas na e pela própria experiência íntima do movimento.

Este fato, o do aspecto não figurativo da dança de possessão, conforme Segato, se dá no modo peculiar em que o corpo concentra e libera a tensão muscular, segundo o orixá do qual se é filho-de-santo. Essa relação, quando ligada à respiração (acrescento), demonstra a personalidade de cada santo, que transcende a dança de possessão para impregnar também o comportamento típico, a postura e o gestual das filhas-de-santo na vida cotidiana.

Para perceber mais esse aspecto não figurativo fiz minha uma idéia de Blacking (1977:5) que diz que: "o corpo do observador pode servir como um instrumento de diagnóstico", e continuando:

"(...) experienciar os corpos de outrem através de nossos próprios corpos e aprender mais a respeito dos estados somáticos que nós podemos entender, mas a respeito dos quais pouco sabemos além de descrições verbais inadequadas...".

Assim, seguindo sempre as idéias de Segato (1995: 169), recorri a uma técnica que pode ser chamada de "imitação silenciosa" ou de "movimento simpático interno", focalizando e repetindo dentro de mim os movimentos dos santos considerados mais "bonitos" ou pelos quais tinha mais simpatia.

A mera execução das coreografias não remete a uma compreensão mais profunda da dança de possessão, pois é difícil captar o estado físico e emocional no qual o movimento tem origem; o que quero, no entanto, é chegar a entender as fontes dos processos fisiológicos que se traduzem em movimento "fechando-se, assim, o círculo da compreensão do que seja a relação entre o orixá e a possessão por ele". (Segato, 1995: 170)

Acrescento que as danças, assim como os ritmos, têm várias funções, como a de abrir e fechar a festa, de ser um dos meios para entrar em transe, além de expressar as características dos orixás. Há movimentos que expressam os sentimentos, como o ijexá que exprime alegria e festa; e os que identificam a honra e a realeza, como o jincá, que consiste em um movimento dos ombros.

\subsubsection{A descrição da dança das Aiabás: as frases corêuticas}

Como exposto anteriormente, as danças no candomblé são de dois tipos: as executadas em estado consciente e as coreografadas em estado de transe.

A primeira parte do ciclo corêutico é o xirê, dançado no começo das festas. As filhas-desanto participam formando uma grande roda na qual todas as energias da natureza são chamadas 
a descer e a participar da cerimônia. A formação dessa roda poderia ser a tentativa de construir um espaço sagrado onde se concentrariam as energias dos orixás. A segunda parte do ciclo corêutico é a dança do orixá, executada em estado de consciência alargada, pois os adeptos estão em transe; é o próprio orixá neste momento que dança, e é a própria dança que cria o orixá em estreita relação com os toques. A divindade mostra ao público sua história mitológica, redistribuindo, então, a energia vital e trazendo o mundo sagrado de volta ao cotidiano.

No começo do xirê os fiéis mostram uma atitude similar em relação ao corpo. Depois, iniciam-se os movimentos específicos para cada orixá. A parte superior do corpo é levemente curvada para frente, os pés estão em contato constante com a terra e as pernas estão levemente flexionadas. A cabeça está relaxada, os braços estão dobrados, seguindo os padrões das danças de cada orixá. Essa atitude do corpo é a mesma em quase todo o xirê. Mudam-se, no entanto, os movimentos específico de cada orixá. As filhas-de-santo encontram-se em estado de espera, pois elas podem intuir quem irá receber. Existem, de fato, detalhes ligados ao corpo que anunciam a chegada do orixá, como o de se coçar - na maioria das vezes na cabeça e atrás das orelhas uma leve ou maior agitação. Também notamos certo nervosismo nas sacerdotisas antes dos rituais.

Tentarei descrever os passos da dança junto com algumas das cantigas referentes a elas. Será uma tentativa porque cada festa de orixá tem uma seqüência de cantigas diferente, dependendo do orixá para o qual a festa está sendo organizada e dos sacerdotes que participam. Desse modo, existem danças executadas apenas nas festas de determinados orixás e não na festa das aiabás, que irei descrever e analisar ${ }^{153}$. Os passos das danças serão descritos dividindo-se os movimentos com base em duas partes: o modelo do passo em locomoção e o da gestualidade do corpo parado, como se fosse uma fotografia.

Acrescento também que a seqüência correta das cantigas é aprendida somente ao longo do tempo da iniciação, e cada casa de candomblé tem uma tradição própria, apesar da origem comum. Um outro obstáculo é a transcrição do iorubá, pois, devido à dificuldade de pronúncia, a mesma palavra, às vezes pode aparecer em tons diferentes, que dão sentidos diversos. As cantigas foram recolhidas ao longo de minha pesquisa de campo e com a contribuição, relativa à parte escrita, do estudo de Altair B. Oliveira (1993).

Passo, então, a descrever uma festa das aiabás que aconteceu no terceiro domingo de outubro de 2000. As Festas de Oiá, de Oxum e de Iá (Iemanjá como é chamada no Axé) são organizadas após essa data. Trata-se da festa das abiãs e cabe a elas pensar em tudo a fim de que a cerimônia seja bem sucedida.

Procurarei, portanto, montar uma seqüência na qual a cada dança corresponda seu ritmo ou cantiga. Nesta referida festa, o xirê seguiu esta ordem: Ogum, Oxóssi, Omulu, Oxum, Euá, Oiá, Iemanjá, e Roda de Xangô com a dança de Obá.

Ninguém incorpora Obá no Axé Opô Afonjá, mas ela, mesmo assim, é homenageada, pois foi uma das esposas de Xangô.

\footnotetext{
${ }^{153}$ Para o calendário das festas do Axé Opô Afonjá, veja-se Marinho (1989) ou Mestre Didi (Santos, 1994).
} 
No xirê, a primeira aiabá a ser louvada é Oxum. Eis suas cantigas:

1) Cantiga para Oxum

O ní iyá beere,ó ní iyá beere ó,

O ni ìyá beere ó, ó ní iyá bé lòpò omo

Osun a dé omo wa.

(Ela é a grande mãe, ela é a grande mãe, ela é

a grande mãe. Ela é a mãe a quem suplicamos para

Termos muitos filhos. Oxum é quem nos dá filhos).

2) Cantiga para Oxum:

E fibó e fibò dò wa ìyá Osun,

E fibó dò wa ìyá Osun, e fibò dò

Wa ìyá Òsun

(É ela quem nos cobre (protege), ela quem nos cobre

no rio, é a mãe Oxum, ela quem nos cobre no rio, é a mãe

Oxum, é ela quem nos cobre no rio, é a mãe Oxum.)

Nessas cantigas, Oxum dança inicialmente com as mãos fechadas e com o punho na frente do peito, depois, estica os braços ao longo do corpo. Nesse movimento do corpo, abre a perna direita e, dando um outro passo, a esquerda. E roda sobre si mesma para mostrar a sua beleza e o fato de que ela é uma mulher completa: possui todas as belezas. O que mais caracteriza seu passo são os pequenos movimentos rotatórios dos ombros. Tal movimento, muito apreciado no candomblé, é algo de difícil execução, apesar de sua simplicidade, porque tem a ver com a articulação da escápula. Conforme Drewal (1989: 216), também entre os iorubás da Nigéria a articulação deve ser bem solta. Merece ser sublinhado que muitos orixás executam esse movimento em suas danças, cada um numa dinâmica energética diferente. Segundo alguns informantes, há exercícios específicos para soltar esse movimento no roncó.

\section{Cantigas para Oiá}

1)

Oya kooro un ó geere-ge

Oya kooro 'nlá ó gàrá gé

Obinrin solala kooro nílé geere-geere

Oya kiomò ré lo

(Oiá ressoou a casa, incandescendo brilhantemente,

Oiá ressoou com grande barulho. Ela corta com o raio,

Ela corta com o raio, é mulher arrasadora, que ressoa na casa

Sensual e inteligente. A Oiá cumprimentamos para conhecê-la mais.)

2)

Oya odò hó yà-yàyà, odò hó yà-yà,

Oya odò hó yà-yàyà, odò hó yà-yà.

(Oiá é o redemoinho dos rios, redemoinho dos rios,

Oiá é o redemoinho dos rios, redemoinho dos rios). 
Dança-se com os braços esticados para frente na altura dos ombros, que se dobram na articulação dos cotovelos; depois, os braços balançam-se para o lado direito e esquerdo, como se estivessem ao vento.

\section{Cantigas para Iemanjá}

1)

\section{Marabo aio, Iemanjá,}

Marabo aio, Iemanjá

(Estamos protegidos, agora estamos satisfeitos.

Iemanjá nos protege e nos enche de satisfação).

2) Orisa ìyá e sogbé iyá dé gbé,

Orisà iyá iyá sogbé iyá dé gbé

(O orixá é a nossa mãe.

Oh mãe, protegei-nos)

Dança-se em fila indiana, com os braços dobrados e as mãos fechadas na frente do peito, abrindo-se alternadamente o braço direito e o esquerdo. A cabeça movimenta-se levemente, como se seguisse o movimento da água. Disseram-me que essa série de movimentos representava Iemanjá com as suas espadas, mas o movimento todo lembra as brânquias de um peixe que se abrem para respirar, enquanto a cabeça, leve, se movimenta na água.

Uma informante nigeriana me disse:

"Iemanjá, Mammyi Water, é um peixe, um grande peixe que se transforma em mulher. Antes que chegassem os brancos ela saía do rio, lá na áfrica, após terem chegado todos aqueles turistas, ela não quis sair mais."

Depois do toque que chama os orixás e após as incorporações, desceram para a festa: Oiá incorporada em duas filhas, Oxum, em dois filhos, Nanã, em dois filhos, Iemanjá, em uma filha, Ogum, em um filho e Oxóssi, em dois filhos.

Durante essa fase do ritual podem acontecer as incorporações, que, aliás, não são todas simultâneas. A forma da gestualidade e a intensidade que ocorre na incorporação é diferente para cada orixá. Como pude observar no barravento ${ }^{154}$, o movimento do corpo que a fillha-de-santo faz no momento da descida do orixá de Oiá-Iansã é o de rotação sobre si mesma, com os braços abertos, como que imitando o movimento de um furacão. Quando uma filha-de-santo cai no santo, continua dançando, mas fora da roda sagrada. É claramente perceptível uma mudança interna, porque a dança é muito mais fluida e o corpo desliza no chão. Às vezes, o movimento é tão rápido e leve, que parece "algo" voando, sem uma direção precisa. Depois da "caída" das outras filhas, os orixás são levados para serem paramentados.

E assim começam as danças chamadas de primeiras de dar rum, elas servem para os orixás se sintonizarem com o atabaque principal, o rum e com o alabê. As três aiabás: Oiá,

\footnotetext{
${ }^{154}$ Barravento também é o nome de um toque.
} 
Oxum e Iemanjá têm quase o mesmo movimento no dar o rum, mas os movimentos dos braços são diferentes. Os orixás incorporados esperam de lado a sua vez e, seguindo a hierarquia, cada um pega o rum.

\section{Canção de dar rum para Oiá}

Oya dé e láárí ó ó ní jé kàrá ló

Jínnòn si àwa'. Oya dé e láárí ó, ó ní

Jé kàrá ó jìnnòn si àwa.

(Oiá chegou, ela possui alto valor, ela é quem pode

mandar os raios para longe de nós. Oiá chegou, ela

possui alto valor, ela é quem pode mandar os raios

para longe de nós).

Com a primeira parte da cantiga os fiéis convidam Oiá-Iansã a entrar em casa. Na segunda parte, ela é homenageada. A terceira parte é a sua exaltação: ela é tão poderosa que pode afastar os raios.

\section{Canção de dar rum para Oxum}

\section{Iyá omì ní ibú odòomi rò Orisà ó lé lé}

Iyá omì ní ibú odòomi rò Orisà ó lé lé

(Mãe das águas profundas que correm no rio, orixá que paira sobre a nossa casa)

Oiá e Oxum executam o mesmo passo com os pés. Ele é como um caminhar rápido, e o pé, atrás, quando se levanta no contratempo, empurra o corpo inteiro. Os braços acompanham alternando o balanço dos pés, como se procurassem por algo. Enquanto Oxum balança os braços com muita energia, mas sempre com uma certa coqueteria - pois ela traz a riqueza no pano da costa -, Oiá pega na saia e a balança para a frente e para trás, como se essa estivesse cheia do vento que ela espalha.

\section{Canção de dar rum para Iemanjá}

\section{Kini jé k'ní jé olódodò Yemonja ó}

Ki a sòró péléé, iyá odò iyá odò

(Quem é a dona dos rios? É Iemanjá a quem nos dirigimos expressando simpatia, mãe do rio, mãe do rio)

A coreografia de Iemanjá é muito diferente, pois ela se locomove horizontalmente: três passos à direita, três passos à esquerda. Os braços acompanham o movimento dos pés, inclusive de lado. Os braços ficam dobrados, na altura do cotovelo, e os movimentos são como se Iemanjá estivesse embalando uma criança com as duas mãos paralelas. No terceiro passo dá um leve pulo 
e suspende a saia, pois ela traz água. Então faz um movimento de pés parecido com o de braços. Esse passo parece com o movimento das ondas. O toque lembra o opanijé de Omulu, porém é menos pesado.

Apesar das três aiabás terem a mesma estrutura de movimento dos pés, a qualidade e o esforço são diferentes, pois a energia delas é diferente. Oxum, por exemplo, anda como se deslizasse na água, mas com mais alegria, enquanto Oiá locomove-se ameaçadora e em linha reta. Iemanjá, por outro lado, anda tranqüilamente e compassada, quase como uma matrona farta: dois passos e uma parada. Ela possui um movimento mais lateral, mais suave, como se abraçasse alguém, que dá a idéia de um balanço estável. Soa estranha essa noção de uma mobilidade estável, mas é exatamente essa a sensação da dança de Iemanjá: é um movimento eterno.

As três orixás são chamadas periodicamente pelo apelo do rum, pois ele deve ser saudado. $\mathrm{Na}$ dobrada do toque elas fazem uma pequena corrida suspendendo a saia e, na terceira vez, param em frente aos tambores, à espera do começo do toque.

Quando todos os orixás acabam de tomar o rum, são levados para serem vestidos. Nesse ponto há uma parada e os orixás entram paramentados, puxados pela iaquequerê (mãe pequena) da casa, segundo a hierarquia do mas velho no santo, tendo sempre à frente Ogum ou uma outra divindade masculina. Nessa entrada os movimentos apresentam-se lentos, pesados, solenes. Os braços abrem e fecham na altura do cotovelo, expressando muita lentidão e dignidade. A cabeça mantém-se altiva. Os pés caminham, abrindo-se para os lados. Às vezes um determinado orixá pode ter nos braços um buquê de flores, mas o movimento do braço é o mesmo, como se o corpo balançasse. Pelo jeito de se mover e pelos trajes litúrgicos característicos, os orixás parecem que estão voando. Entram acompanhados pelo canto ago, ago l'ona (dá licença, dá licença). Todos os orixás fazem esse mesmo movimento nessa ocasião. Depois dos orixás terem se apresentado ao público, começam as danças sagradas.

A primeira a dançar naquela festa foi Oiá. O orixá se apresenta com um movimento típico de todos, se balançando um pouco sobre si mesmo e com os braços postos atrás das costas, à espera do toque. Quando o orixá é de uma pessoa feita a pouco tempo, ele põe as mãos do lado esquerdo da barriga. Lembramos que a esquerda é considerada sagrada entre os iorubás, pois é o lado dos espíritos. (Drewal, 1989: 208). Logo no começo da música, ela deu o seu ilá característico e saudou o público com um movimento de abrir os braços para o alto e cruzá-los na frente da barriga.

A descrição a seguir trata de uma Oiá-Iansã genérica. De fato, é quase impossível identificar uma só qualidade de orixá, pois trata-se de algo secreto e aprendido no momento da iniciação e, por outro lado, perceptível na qualidade ${ }^{155}$ da dança e nos paramentos litúrgicos. Uma Oiá ligada a Xangô, por exemplo, terá roupas predominantemente vermelhas, enquanto uma ligada aos eguns irá se vestir de branco. Mas há muitos outros elementos interligados, inclusive nas cores.

\footnotetext{
${ }^{155}$ Entende-se por "qualidade da dança" o tipo de esforço, ou seja, de energia colocada para executar aquele passo em particular.
} 
É a percussão dos dois tambores menores que sinaliza o passo de base, enquanto o rum manda nas variações. Do ponto de vista rítmico, há uma polirritmia que origina vários centros de pulsação no corpo humano que devem, porém, se juntar em um todo.

A dança de Oiá-Iansã expressa tanto sua energia violenta e agressiva, própria da guerreira pronta para lutar, quanto a leveza e a fluidez do ar. Quando ela é fogo, roda sobre si mesma, como se vivenciasse as chamas e se preparasse para lutar, movimentando-se como as labaredas que começam a queimar, primeiro numa pequena dimensão e, em seguida, com altura e imponência. Oiá-Iansã rodopia empurrando a parte superior do busto para a frente e abrindo os braços. Não está, portanto, em equilíbrio perfeito. Depois que as equedes tomam conta das "ferramentas" das Oiás, iniciam-se suas várias coreografias.

Nas danças, existe um padrão fixo, mas são as filhas-de-santo que as interpretam criativamente. Quando a orquestra começa a tocar o ilu, todo mundo fica de pé e parece que a platéia inteira participa, gritando "Eparrei!" e batendo palmas. O entusiasmo, então, toma posse do público. Atrás da orquestra, um grupo de adolescentes acompanha as danças dos orixás dançando, cantando e batendo palmas, num crescendo contagiante.

No começo, Oiá dança na mesma atitude corporal do xirê, isto é, com o corpo curvado para o chão e com as mãos imitando duas espadas, que deslizam para direita e para esquerda. Ameaçadora, de repente se joga, rápida, perto de alguém, sem nunca tocá-lo, porém, passa leve na frente dele. Depois dessa primeira dança, Oiá pára repentinamente. Uma das fiéis tem as mãos para trás sobre o quadril e suspende um pouco sua saia. O rosto - transformado depois da incorporação do orixá - é bem fechado, os lábios estão alongados e o pescoço, ereto. A parte superior do corpo está voltada para a frente, dando a impressão de arrogância e de superioridade. Oiá-Iansã anda como se fosse a dona do barracão, a sua postura é completamente diferente da doçura de Oxum ou Iemanjá.

Oiá anda um pouco e, de repente, fica parada e se curva sobre si mesma, com as pernas flexionadas. Depois, estica os braços para a frente e dá o seu grito particular, o ilá, que é muito forte e peculiar. E logo retoma sua coreografia no ilu: os pés abrem à direita e à esquerda. Abrindo-se à direita, o pé esquerdo logo alcança o seu par, com um pequeno contratempo, a mesma coisa acontece do lado esquerdo. O corpo fica ereto. Os braços, dobrados para frente, são levantados para o alto, em direção ao lado direito - quando os pés abrem desse lado - e ao lado esquerdo. Nessa coreografia, não se coloca a ponta os pés no chão; os dedos maiores mantêm-se levantados do chão e os pés também ficam apoiados no lado externo, de modo que, tanto o lado interno dos pés, quanto as pontas dos dedos estão sempre levantados, dando a impressão de uma grande tensão interna. Os braços são levados até a altura da cabeça e dobram-se na altura do cotovelo, todo o corpo gira, de um lado e do outro, e esse movimento faz referência ao elemento ar.

Segundo uma informante, essa dança simboliza Oiá-Iansã espalhando o vento e sacudindo a sua saia, cheia de vento (id: 108).

Mudando o toque, começam as cantigas (id: 106/107) e, então, temos:

Oya kooro nílé ayba tun balé 


\section{Oya Oya kooro nílé ayba tun balé}

(Oiá ressoou na casa e eu a reverenciei humildemente, prostrando-me no chão. Oiá ressoou na casa e eu a

Reverenciei humildemente, prostrando-me no chão.)

Nessa cantiga Oiá, com um movimento oscilante da bacia, toca com os dedos o adê (a coroa), simbolizando que ela é rainha e que solta os ventos da sua coroa. Depois dessa cantiga a equede dá os símbolos ao orixá, nesse caso, uma espada e o eruquerê (o espanta moscas, símbolo de realeza na África). A dança de Oiá-Iansã expressa as possibilidades dinâmicas do seu elemento, o ar. Ar que, movimentando-se rapidamente, gera o elemento fogo, junto com a energia de Xangô. Como me disseram várias vezes, todas as suas danças referem-se à guerra.

$\mathrm{Na}$ retomada do ritmo, a Oiá-Iansã joga-se em direção de Ogum — que havia sido incorporado antes - e oscila seus quadris na frente dele, com uma clara alusão sexual. Lembremos, a propósito, que ela expressa a sexualidade livre. O povo diz que: "Oiá é livre, ela gosta de andar e pára onde ela quer, sem pedir licença a ninguém. Ela pega o que é dela". Mas ela também luta com Ogum. Enfrentando-se, os dois procuram onde golpear, viram para o lado direito e esquerdo e posicionam as mãos, que representam suas espadas, na altura da cintura, e, logo depois, pulando para o alto, colocam as espadas sobre as cabeças, numa dança que lembra a antiga luta entre eles, quando Oiá fugiu de Ogum, traindo-o com Xangô.

Há um lado de Oiá muito importante que lhe permite ser a única orixá presente na festa dos eguns, pois, sendo ela o elemento ar, tem a função de levar os espíritos do aiê até o orum. A cantiga que expressa melhor quem ela é (id: 105) é a seguinte:

Só só só ekuru, Iansa no Ibó, ekuru

Só só só ekuru, Iansa no Ibó, ekuru.

(Quebra o vento, quebra o vento, quebra o vento.

e varre a poeira suspensa no ar, Oiá varre a poeira

suspensa no ar.)

Outra cantiga (id: 107) diz:

Bírí ibi ré Oyá, lojú ògbéri kò mòn mònriwó

Bírí ibí ré Oyá . lojú ògbéri kò mòn mònriwó.

(Esta é uma pequena porção do culto, mas os olhos

dos não-iniciados nos mistérios do culto não

conhecem os segredos encobertos pelas folhas

da palmeira.)

Com essas duas cantigas Oiá-Iansã locomove-se levemente, como se estivesse abrindo um caminho. $\mathrm{O}$ corpo inteiro é direcionado para o alto, mas sempre com um forte impulso que empurra a sua locomoção. Numa mão, ela tem o eruquerê, com o qual limpa o lugar dos eguns, enquanto que com a outra, afasta os espíritos dos mortos.

Há, ainda, um outro passo relacionado ao afastamento dos mortos: os pés seguem o passobase já descrito, nas pontas dos pés, com cruzamento atrás, enquanto os braços - levantados sobre a cabeça e levemente dobrados — parecem empurrar algo com um forte movimento das 
mãos abertas, mas com os dedos fechados para dar mais força a esse movimento. Oiá-Iansã parece voar, com o corpo a deslizar. Às vezes, quando ela leva numa mão o eruquerê, a altura dos braços é mais baixa. Com esse gesto ela limpa o lugar dos mortos.

Ocorre, então, uma troca rápida da música. O orixá pára e corre na direção dos atabaques, pegando a saia com as mãos, com passos rápidos para frente e para trás. Essa corrida é repetida pelo menos três vezes. Durante essa dança, o orixá sai pela entrada principal do barracão. Oiá, assim como Omulu e Ogum, podem sair do barracão porque são orixás de "rua". Ela saúda os ancestrais e Exu, o guardião da porta. Saúda também os atabaques, a mãe-de-santo e os outros membros religiosos mais importantes.

Quando Oiá pára, como qualquer outro orixá, faz um movimento de saudação particular, chamado jincá. Um frêmito percorre-lhe o corpo inteiro, da cabeça até o fim das costas, e o corpo todo dobra-se para a frente e para trás. Esse é um movimento de saudação. A cabeça permanece em linha com as costas. Os braços caem ao longo do corpo. É um movimento que, de dentro, espalha-se para fora. As pernas ficam dobradas e paralelas para sustentar o movimento das costas.

Antes de ir embora, ela posiciona os braços como que para se abraçar e os abre para abençoar a todos e distribuir energia. Faz esse gesto com a parte superior do corpo inclinada para a frente e com a bacia para trás. Às vezes, ao passar perto do público, abraça os fiéis mais próximos.

\section{Oxum}

A dança típica de Oxum é o ijexá, que também é o nome de um toque muito popular e querido na Bahia, pois é o ritmo adotado pelo afoxé Filhos de Gandhi. Quando os tambores começam a tocar, as pessoas pulam em pé e logo participam, batendo palmas e seguindo, sentadas ou de pé, a dança, que, sendo aparentemente simples, na realidade precisa de uma grande sincronização dos movimentos e de uma sutil consciência corporal, pois seus movimentos são pequenos e quase imperceptíveis.

O centro do movimento de Oxum que é a dona da fertilidade, é a bacia. Seu movimento ondulatório propaga-se até os ombros, como uma pequena onda. Os ombros rodam sobre si mesmos, levemente, ligando-se ao pescoço. Os pés fazem um movimento de abertura seja do lado direito, seja do lado esquerdo, e, contemporaneamente, abram-se os cotovelos. Mas o que mais caracteriza e manifesta a qualidade e a energia dos movimentos de Oxum é o movimento dos ombros, que é diferente do jincá de Iemanjá, pois o de Oxum é mais redondo, mais leve, suave, e ela o utiliza para atrair seus amantes ou as coisas de que precisa. Cada orixá tem suas artes e artimanhas. Às vezes o orixá pára e dança mexendo apenas os ombros e as mãos, como se quisesse atrair as coisas, e desliza, leve e verticalmente, como se estivesse dentro da água, enfim, como se esvaecesse. Dizem que a famosa ebômi Pinguinho, ao rodar seus ombros, fazia cair no santo qualquer pessoa, tanto era cheia de axé a sua dança.

Mais tarde Oxum inicia outra vez seu movimento com os pés dançantes. Ela anda muito rápido, como se tivesse patins por baixo, e aproxima-se das pessoas, mas, repentinamente, muda 
de direção. Nunca acontece de alguém ser tocado, pois o orixá possui um grande domínio no equilíbrio e nos movimentos, inalcançável em estado normal.

Nesse momento, temos cantigas como:

Rora yéyé omi a sa wé ré o, rora yéyé omi

A sa wé ré, àwa omon e yéyé ó

(Cuidadosa mãe das águas, nós queremos tomar banho com você, somos vossos filhos ó mãe.)

Olóomi máà, olóomi máà iyo

Olóomi máà iyó ‘wnyin ayaba odò

Oyéyé ó.

(Senhora das águas doces, Senhora das águas sem sal, é a velha mãe do rio,

Oh mamãe).

Aláadé Osun, Osun mi yéyé ó,

Aláadé osun, Osun mi yéyé ó

(Oxum dona da coroa,

Oxum é minha mãe, Oxum dona da coroa,

Oxum é minha mãe.

Sempre dançada no ijexá.)

Nessas danças estão presentes seus movimentos típicos (o ijexá): roda sobre si mesma e preenche, em círculo, o espaço do barracão. Enquanto Oiá anda em linha reta e em ziguezague, Oxum movimenta-se em e com um círculo. Ela mostra toda sua leveza e doçura nessas formas circulares. Até quando uma delas pega a espada, não a utiliza, como Oiá o faz, numa atitude de penetrar com força o espaço, mas, apesar do objeto agressivo, ela contorna o espaço, como se a sua agressividade fosse menos forte.

Uma das coreografias mais bonitas é a de quando toma banho e se enfeita com anéis e jóias. Este toque, dizem conforme pesquisa, "puxa do angola", a significar que o ritmo é parecido ao tocado no candomblé de tradição angola.

Depois de alguns passos, nos quais ela anda com os braços balançando para a frente, ela começa a tirar os anéis, as pulseiras, o adê (coroa) e, com os braços e as mãos, pega a água atirando-a sobre si mesma, abaixando-se até se ajoelhar para, novamente, pegar outra porção de água que joga sobre si com uma mão, e depois com a outra, enquanto algumas filha-de-santo suspendem a sua saia - que fica ao seu redor - e a movimentam, como se fossem pequenas ondas de uma lagoa. Depois disso a deusa enfeita-se, colocando outra vez os anéis, as pulseiras e a coroa e levanta-se andando em direção aos atabaques para a saudação ritual.

Se no público há mulheres com crianças pequenas no colo, é muito comum vermos Oxum se aproximar e abençoar os dois, pois ela é uma das grandes mães no candomblé.

\section{Iemanjá}


O toque característico de Iemanjá é o jincá que significa honra. É um toque lento e compassado que revela as características de Iemanjá. A parte do corpo onde nasce o movimento, conforme a pesquisa, é o coração, pois Iemanjá é aquela que acolhe todo mundo.

\section{Marile maribodo}

Sarenan onia

Marile marile maribodo

Sarenan

Marile maribodo sarenan

Marile maribodo sarenan o

Onia aoio e

Marile maribodo sarenan

Marabo l'ayo

Yemonja

Marabo l'ayo

Yemonja

Iya lode erece

(Iemanjá é a guardiã da coroa, ela é uma guardiã firme)

Aqui ela dança mexendo os ombros e com as mãos fechadas pois ela sempre segura o abebê e a espada ou um peixe.

Oniye Yemonja

iyá pota pelebe aoio

iyá dorofin oniya sarele o

Oniya sarele o

Iya dorofin oniya aso iye iye o

Nas danças que seguem às de dar rum uma das coreografias de Iemanjá se assemelha, um pouco, àquela do xirê: a deusa se prepara com os braços e - sempre rodando sobre si mesma $\mathrm{e}$ pelo barracão, em um tempo não simétrico — joga-se debaixo d'água. Ela mergulha e anda rápida, jogando também a saia. Lembro-me de um fato ocorrido há alguns anos atrás quando uma maravilhosa Iemanjá mergulhou, com a sua saia e tudo, e, ao passar na frente de um filho-desanto de Ogum, levou-o consigo numa dança da mãe com o filho.

\section{E bau, bau}

Essa dança tocada com uma velocidade lenta (no toque chamado de vassi) e que deve expressar um caminhar arrastado, quase como o de um velho: com as duas mãos em forma de concha, cada vez que muda o passo, a mão que está por baixo vai para cima e vice-versa; como se a pessoa tivesse que segurar algo nas mãos. O movimento se amplia no lado horizontal: os braços estão bem redondos e toda a postura do corpo é arredondada e transmite uma idéia de acolhimento. Nesta dança Iemanjá pega água e areia. 
Vimos essa mesma dança no terreiro da casa Branca, em 26 de novembro de 2000. Aqui, o que chama a atenção é a rapidez do movimento dos pés e o uso do espaço. O orixá dança muito dobrado para baixo, como se fosse uma onda das profundezas. Nessa mesma festa uma das velhas ebômi dançou para Iemanjá com um movimento de braços abertos à altura dos ombros e levando para a frente, alternadamente, um e o outro ${ }^{156}$ braço.

\section{Manja odó, manja é}

Nessa outra, muda o movimento dos braços. A postura do corpo é sempre arredondada e dobrada um pouco para a frente, enquanto os braços estão posicionados com os cotovelos largos. Numa outra, as mãos fechadas estão uma em cima da outra, como se Iemanjá estivesse batendo algo entre as duas mãos. Disseram-me que ela está no pilão, preparando comida para seus filhos.

Seu toque às vezes é esticado rapidamente e chega a parecer um dos toques de Xangô, o tonibobé. Iemanjá anda como se estivesse afastando alguém com os braços levemente arqueados. Eles podem estar um pouco mais para a frente dos ombros e abaixo dos seios. Dizem, então, que segundo uma lenda, a deusa está afastando um cachorro que a impedia de colher as favas, alimento de que ela tanto gosta.

Durante essa mesma festa, foi clara a importância do jincá, que corresponde a um movimento dos ombros feito em ocasião da dobrada do rum. Tal movimento, muito apreciado entre os iorubás, como demonstra Drewal (1989: 217) tem uma possibilidade dinâmica muito grande porque os ombros podem ser mexidos muito rapidamente, mas também mais suavemente. Conforme um informante, esse movimento dos ombros simboliza nobreza, do mesmo modo como outros movimentos simbolizam felicidade, realeza etc.

\section{Obá}

Como já foi dito, não há o transe desse orixá no Axé Opô Afonjá, mas, pelo fato dela ser uma das esposas de Xangô, canta-se e dança-se para ela na roda de Xangô.

Quando toca-se o batá, todos os filhos-de-santo se dispõem em círculo, ombro a ombro, olhando para o seu centro. Então, levantam a mão direita e dão um leve pulo com o pé esquerdo, depois, levantam a mão esquerda e dão um leve pulo com o pé direito. A um certo ponto, mudam de movimento e as mãos viram arco e flecha, como na dança de Oxóssi e Logum Edé, o filho mítico de Oxóssi com Oxum, pois Obá é uma caçadora. O movimento termina quando os fiéis voltam, em fila indiana, levando o braço direito para a esquerda e vice-versa.

Vi, porém, no Nordeste de Amaralina, um outro terreiro ligado ao Gantois, que visitei no dia 9 de setembro de 2000, uma moça que incorporou Obá. Seu movimento era basicamente igual ao descrito em sua roda, mas depois de ter levantado a mão aberta para frente, tanto do lado

\footnotetext{
${ }^{156}$ Vimos um tipo de movimento bem parecido num vídeo feito por Margaret Thompson Drewel, chamado Yoruba Ritual.
} 
direito, quanto do esquerdo, e sempre com um leve pulo, ela levava as mãos à orelha direita, querendo destacar a característica de sua história mítica.

\subsubsection{Descrição coreográfica da temática}

Essa parte é mais uma síntese do movimento e não dá conta da dança de transe. Serve, no entanto, para fixar um pouco mais o movimento.

Descrição desenvolvida separando-se o movimento em unidades chamadas de tema:

Tema 1: consciência do corpo, ou seja, o conhecimento das articulações, que se movimentam e das partes do corpo:

- $\quad$ postura corporal = Oiá: linha ereta; Oxum e Iemanjá: linha redonda;

- $\quad$ cabeça = Oiá: posicionada para os lados, mostrando o perfil para a direita e para a esquerda; Oxum e Iemanjá: para frente, mostrando todo o rosto;

- $\quad$ expressões faciais = Oiá: musculatura facial tensa, exibindo pequenos movimentos faciais sutis, projeção dos lábios e olhos cerrados; Oxum e Iemanjá: facial suave, às vezes com um sorriso. Iemanjá chora;

- $\quad$ ombros = Oiá: movimentos contínuos dos ombros, acompanhados pelo leve levantamento dos braços; Oxum e Iemanjá: contínuos dos ombros, mas leve e rotatório;

- braços = Oiá: posicionados para a frente; Oxum e Iemanjá: posicionados de lado;

- pés = Oiá: movimento deslizante. A cada passo, os pés se juntam num contratempo e se separam; Oxum e Iemanjá: movimento deslizante. Os passos são feitos lateralmente;

- $\quad$ pernas = Oiá, Oxum e Iemanjá: conduzem o movimento dos pés para o tronco, com os joelhos flexionados;

- quadris = Oiá e Oxum: movimento para trás, com a projeção do busto para frente, para Oxum, o movimento é mais suave e para iemanjá, é apenas um acompanhamento.

Tema 2: consciência do peso e do tempo, isto é, a entrega do corpo às forças de gravidade:

- $\quad$ força = Oiá, Oxum e Iemanjá: forte;

- peso $^{157}=$ Oiá e Oxum: leve; Iemanjá: pesado;

- $\quad$ tempo = Oiá, Oxum e Iemanjá: de percussão.

Tema 3: consciência do espaço, quer dizer, o conhecimento do local que o corpo ocupa e as direções que ele alcança no espaço:

\footnotetext{
${ }^{157}$ Tratarei mais detidamente do peso e ad força mais adiante.
} 
- Oiá, Oxum e Iemanjá: rodam sobre o próprio eixo e fora dele;

- direção = Oiá, Oxum e Iemanjá: sentido circular anti-horário;

- Oiá: uso de diagonais acentuadas e de retas abertas; Oxum e Iemanjá: uso de círculo e caminhadas em círculo.

Tema 3.1: pontos referenciais de deslocamento no espaço circundante:

- Oiá, Oxum e Iemanjá: porta de acesso principal - Exu do portal e os ancestrais —; Oiá sai fora da porta;

- Oiá, Oxum e Iemanjá: orquestra (os atabaques), o agogô e a cabaça forrada com contas;

- Oiá, Oxum e Iemanjá: cadeira da Ialorixá;

- nenhuma: centro do barracão, onde está enterrado o axé da casa, somente durante as rodas;

- Oiá, Oxum e Iemanjá: os ogãs e o público;

- Oiá, Oxum e Iemanjá: pessoas com cargos especiais, como os Obá de Xangô.

Tema 4: consciência do fluxo do peso corporal, ou seja, o conhecimento da fluidez do movimento no tempo e no espaço:

- no tempo = Oiá: velocidade rápida e de percussão; Oxum e Iemanjá: velocidade rápida e lenta;

- no espaço = Oiá: caminhos retos com linhas fazendo ziguezague; Oxum e Iemanjá: caminhos em andamento circular com círculos.

Tema 5: relacionamento com os outros orixás, isto é, a postura que se deve tomar perante os demais orixás:

- Oiá, Oxum e Iemanjá: organização hierarquicamente estabelecida, relação com os orixás com os quais têm uma ligação mítica.

Tema 6: uso instrumental dos membros do corpo, ou seja, o conhecimento do uso de uma parte corporal como instrumento:

- Mãos = Oiá: esquerda e direita como segurando a frente de sua saia; Oxum: sempre um pouco fechada; Iemanjá: aberta como acompanhando;

- Pés = Oiá: sempre um pouco atrás do centro de gravidade e como se fizesse base pelo corpo que vai abrindo-se para o céu; Oxum e Iemanjá: um pouco atrás do centro de gravidade, fazendo, porém, base para a abertura da parte do busto do corpo;

- $\quad$ ombros e braços = Oiá: dirigidos para a frente; Oxum e Iemanjá: direcionados para o lado;

- $\quad$ tronco = Oiá: postura ereta; Oxum e Iemanjá: postura curvada 
Tema 7: consciência de ações isoladas, quer dizer, o conhecimento da tomada de decisões diante de certas posições completas:

- movimentos = Oiá: fortes, com grande tensão, precisão, determinação e força física; Oxum: movimentos leves, com relaxamento, precisão, determinação, deixando fluir; Iemanjá: movimentos doces com tensão, precisão, determinação, deixando fluir;

- acentuação do ritmo = Oiá: no contratempo; Oxum e Iemanjá: acentuação na base do ritmo.

Tema 8: desenho do movimento, quer dizer, a forma do movimento e as direções a partir da esfera do movimento:

- deslocamento do corpo = Oiá: frontal, para trás e com diagonais laterais, ocupando todo o espaço; Oxum e Iemanjá: circular e em círculo, ocupando todo o espaço;

- direção dos pés = Oiá: frontal, com pequenos recuos laterais; Oxum e Iemanjá: laterais e para frente;

- cotovelos e braços = Oiá: frontais; Oxum e Iemanjá: laterais;

- $\quad$ cabeça = Oiá, Oxum e Iemanjá: acompanha o movimento do corpo inteiro.

Tema 9: combinações das ações básicas de esforço, ou seja, a junção das ações no movimento (como: socar, talhar, sacudir, torcer, deslizar, flutuar):

- Oiá:

1. Afastar (empurrar) - braços;

2. Deslizar (flutuar) - pés;

3 Empurrar (limpar o caminho) - braços;

4. Cortar o ar (abrir novos caminhos) - mãos.

- Oxum e Iemanjá:

2. Deslizar (flutuar) — pés

Tema 10: orientação no espaço, isto é, a direção definida do movimento no espaço:

- $\quad$ orientação = Oiá, Oxum e Iemanjá: circular, em sentido anti-horário. Ela ocupa o espaço total da área do barracão.

Tema 11: desenho do movimento, quer dizer, a forma geral definida e total do corpo em movimento: 
- Oiá: como se fosse um redemoinho ou como um furacão; Oxum: semelhante a uma onda do rio; Iemanjá: como uma onda do mar.

Tema 12: elevação do solo, ou seja o contato dos pés com o chão:

- Oiá, Oxum e Iemanjá: presente em várias danças.

Tema 13: bênçãos e agradecimentos, entendendo-se a gestualidade corporal para expressar o ato de abençoar e de agradecer:

- Oiá, Oxum e Iemanjá: cabeça baixa e deslocamentos com passadas laterais de frente e próximas aos assistentes. O deslocamento, às vezes, passa a ser através de giros e o movimento alcança uma expansão total, com os braços abertos, na seguinte posição: as mãos transferem o impulso para o centro do peito e, após a concentração que caracteriza um novo relaxamento, reinicia-se o movimento circular do corpo todo no momento em que os orixás saúdam.

Tema 14: formações grupais (o grupo de dançarinos juntos):

- Oiá, Oxum e Iemanjá: em fila e se locomovendo, seguem uma direção circular em volta de um eixo central. $\mathrm{O}$ corpo posiciona-se em relação ao eixo, ora em forma lateral, ora em forma frontal.

Tema 15: qualidades expressivas, isto é, os sentimentos que os orixás transmitem:

- Oiá: orixá guerreira e de rua, ela anda sempre, não pára; Oxum: orixá do amor e da leveza, ela anda com suavidade; Iemanjá: orixá da maternidade e da orientação, caminha continuamente, mas com calma;

- Oiá: característica marcante de ser livre, de sexualidade, de guerreira e de mulher-animal (búfalo); Oxum: característica marcante da sedução, do amor, de se acomodar e de desaparecer, pois é uma sereia; Iemanjá: característica marcante da maternidade, da ponderação, de ser ordenadora e de ser um peixe, ela também costuma desaparecer;

- Oiá: dança como um sopro de vento que abrange tudo e depois vai embora; Oxum: dança como uma onda do rio que desliza e some; Iemanjá: dança como onda do mar. Surge na terceira onda e depois mergulha nas profundezas;

- Oiá: representação da mulher independente, impaciente, às vezes arrogante, outras, generosa; Oxum: representa a mulher sedutora, fascinante, maternal, que quer ser ajudada; Iemanjá: representa a mulher adulta, segura, fascinante, mas ao ponto certo; ela já é a mãe de todos, não precisa de mais nada; carrega os sofrimentos de todos.

Através das entrevistas com as filhas-de-santo e da observação dos rituais, concluí que nas danças de todos os orixás há um padrão que aponta para as seguintes equivalências: 
- um grande contraste entre concentração e expansão, ligados à respiração e à qualidade da energia que está se manifestando na matéria da filha-de-santo;

- incorporação de valores da estrutura espacial externa que são o reflexo de uma estrutura espacial interna, relativa ao orixá dono da cabeça;

- importância da circularidade.

Há as mesmas coreografias para todas as qualidades de orixá, mas cada um deles é criativo, pois deve manifestar a sua composição espiritual, que seria a sua "qualidade" particular. Por exemplo, ser um orixá velho ou jovem, ser um orixá com um juntó diferente dos outros etc.

Conforme Bastide (1976: 115), apesar de serem danças padronizadas há uma espontaneidade nos movimentos e nas energias, quer dizer que a repetição dos gestos não impede uma imaginação criadora.

\subsubsection{Análise da dança}

O sentido das danças, assim como o do ritual em geral, não pôde ser completamente entendido, pois existem vários significados estratificados, os quais são percebidos apenas pelos iniciados e pessoas ligadas à esfera de afetividade e da memória do grupo.

Como nos explica Turner (1967), os símbolos em geral e os das danças, em particular, podem "condensar" vários significados dos grupos sociais contemporaneamente, sejam eles corpóreos analógicos, sejam arbitrários. Por isso, as danças sagradas expressam e manifestam vários sentidos numa única dança. Nessas, corpo e espírito, conteúdo e forma ligam-se numa síntese única e transcendental. A própria forma torna-se o conteúdo e o mito vivo. Essas danças, portanto, não podem ser chamadas de simbólicas, pois no transe assistimos à manifestação em si do sagrado; é a transcendência que está dançando, uma vez que as pessoas do candomblé acreditam ser o orixá manifestado que dança. $\mathrm{O}$ corpo transforma-se mimeticamente no objeto ou no animal que materializa a energia daquela divindade que está sendo homenageada. Oiá-Iansã, sendo o orixá do vento e da tempestade, manifesta o elemento ar que, em movimento, gera o fogo, dentro do qual existem partículas de água; mas também é o próprio búfalo, é a própria borboleta, é também a própria espada, é uma corrente de transformações ao infinito. Assim, Oxum é uma onda do rio, é uma feiticeira potente, é uma doce mãe, é a sedução de ser mulher, é um peixe que nada, é uma sereia que atrai. Iemanjá é a mãe, é também uma sereia, é aquela que orienta todos os seus filhos e torna-se uma espada para protegê-los.

Cada dança de orixá pode ser encarada como uma parte da história da divindade que abrange uma grande época histórica. E, como diz Augras (1983: 153), por exemplo:

"(...) pode-se observar muitos detalhes que sugerem a fusão, na figura de Oiá-Iansã, de várias divindades, de origens diversas (...). A Oiá relacionada com Oxóssi (...) foi provavelmente uma deusa agrária, ligada aos cultos da fecundidade e do boi".

\section{Oiá-Iansã}


Oiá viveu em várias épocas. O fato de ser uma mulher-búfalo deixa bem claro a sua ligação com os caçadores e os nômades que seguiam o movimento dos animais. Como mostra a sua ligação com Oxóssi, o rei da mata, e com Ogum, da mesma estirpe de Odé, ambos caçadores. Já quanto a sua ligação com Xangô, ela tem origem na descoberta do fogo, que a deusa transmite aos homens. Ainda a respeito de sua ligação com Ogum, essa se dá por causa do seu trabalho: junto com ele, na oficina, para forjar o ferro. E, finalmente, quanto a Omulu, ela recebe dele o poder sobre os eguns, que, em algumas lendas, seriam os próprios filhos de Oiá-Iansã. Todos esses aspectos, e outros mais, são expressados nas suas danças, as quais possuem os seguintes aspectos gerais:

1) um movimento circular no começo, a fim de delimitar o espaço "mágico" no qual ela concentra as energias da natureza: o ar, a água e o fogo. Essa rotação é feita também com o movimentos dos braços, que giram com o corpo todo e simbolizam o ar que, quando em movimento, torna-se vento e, sempre mais rapidamente, o furacão e a tempestade (água);

2) um movimento com linhas quebradas e, continuamente, mudando de direção, que simboliza a energia do ar. Como explicou uma filha-de-santo, "o ar está em todo lugar, em cima, embaixo, de lado." Por seguir o movimento do ar, Oiá encontra sempre novas direções, possui e ocupa o espaço agressivamente;

3) um impulso interno nervoso, com movimentos súbitos e rápidos, que descreve a eletricidade e a impaciência dessa deusa;

4) um movimento fluido e leve, que expressa o ar leve e a doçura do orixá, levando os espíritos dos mortos ao orum.

O primeiro movimento pode ser entendido a partir da discussão anterior sobre a roda sagrada. Ele aponta a construção de um espaço mágico, onde se concentram e se fazem concentrar as forças da natureza. Também o contínuo redemoinho que Iansã faz sobre si mesma, simboliza o elemento "ar em movimento", que dá origem ao fogo. Ela ocupa muito espaço, tanto horizontal quanto verticalmente. Às vezes, abre os braços, inclina a cabeça para trás e roda sobre si mesma, desenhando uma espiral com o próprio corpo e locomovendo-se no espaço. Deixa claro, através da sua postura firme, que precisa de muito espaço e que é dona dele. Iansã age com um movimento que, do interior, se abre para o exterior, ela está mais ligada à ação do que à intimidade.

Quanto ao terceiro aspecto, Oiá movimenta-se em diagonal, anda pelo barracão sem uma meta precisa: qualquer coisa nova a seduz e provoca uma repentina mudança de direção. Uma filha-de-santo explicou essa mudança contínua, apontando para a ligação de Iansã com o elemento ar em contínuo movimento: "o ar está em qualquer lugar e movimenta-se sem uma direção precisa". Ela, portanto, transmite o frêmito e a curiosidade do ar, que está sempre à procura de algo ou de alguém. Oiá, nesse sentido, pode parecer quase desesperada, nesse seu andar sem meta e com tanta energia. Oiá é um orixá com características joviais e de guerreiras, que abrem os caminhos, lutando e limpando as energias dos eguns, em qualquer lugar.

O último aspecto relevante é a leveza que ela expressa quando afasta os mortos, transporta algo, ou abre o caminho para os seus devotos. Nessa sua qualidade, ela parece mais dócil e flexível, demonstrando sua generosidade ao transportar as almas ao orum, para uma nova vida. 
Os níveis de seu corpo no espaço - que passam do baixo para o alto - expressam, sensualmente, o elemento ar. O corpo inteiro é como que suspenso no ar, a ponto de os pés não estarem postos completamente no chão. Oiá é mais ligada ao externo, à aventura, à ação livre.

Analisando os níveis espaciais, podemos reconstruir toda a história mitológica de Oiá:

- quando ela dobra para o chão, é a guerreira que se prepara para lutar ou, então, expressa sua transformação como búfalo. Nessa fase, as lendas contam a sua vida afetiva com Ogum e Oxóssi (a mata);

— quando ela ascende seu nível, isso representa a sua ligação com Xangô, o fogo;

- quando seu nível é alto, representa o ar; e as lendas contam a sua ligação com os espíritos dos mortos, que ela transporta ao orum.

É interessante observar a dinâmica no espaço de Oiá: ela toma consciência dele ao andar em todas as direções, inclusive nas diagonais, que simbolizam uma saída da ordem, preenchendo o espaço com uma dinâmica agressiva. Enquanto Iemanjá tem uma dinâmica mais tranqüila, ela constrói ao seu redor círculos concêntricos que vão sumindo dos seus limites. Esse uso diferente da dinâmica no espaço, provavelmente, origina-se da diferença de cultura dos povos que cultuavam as duas divindades. Segundo Leroi-Gourhan (1977: 130):

"A mitologia dos caçadores organiza-se ao redor de um espaço itinerante, como o caminho dos astros ou dos heróis, enquanto a mitologia dos agricultores sedentários organiza-se ao redor de um espaço radiante, como o paraíso sobre uma montanha, com a árvore da sabedoria ao centro e quatro rios que vão aos limites do mundo".

Oiá é ação pura, constrói seu espaço através da ação direta do corpo no espaço.

\section{Oxum}

A mitologia de Oxum (Verger, 1981; Prandi, 2000) é rica em mostrar o quanto esse orixá sabe fazer uso da inteligência. Os contos nos falam de sua famosa beleza e de sua determinação em obter as coisas, seja amor, dinheiro, fama ou beleza. Ela mostra em seu movimento uma suavidade que realmente só pode ser alcançada pela harmonia interior. Seus objetos sagrados são o abebê - um espelho de ouro que compartilha com Iemanjá - e uma espada que só um tipo de Oxum possui, sendo essa, portanto, uma guerreira. Enfeita-se, ainda, com peixes que adornam a sua saia, eles lembram a fertilidade das mulheres e a procriação. Ela é uma das primeiras bruxas, pois pode se transformar em pássaro - ela é a proprietária da cabaça que contém um pássaro, símbolo das primeiras mães antigas, as Iá $\mathrm{Mi}^{158}$ —; mas ela é também um peixe e, por causa disso, pode se jogar na água e desaparecer. Oxum é irreal, é mágica, ela pode sumir e a gente não sabe onde e como reaparecerá.

Em algumas danças ela é acompanhada por Oxóssi, o marido mítico, e Logum Edé, o filho que ela teve com o caçador, ao dançarem juntos o ijexá. Em outubro de 1999, na festa das aiabás, vi no terreiro de Oxumarê a dança desses três orixás: Oxóssi, Oxum e Logum Edé, o que

${ }^{158}$ Veja-se o artigo de Verger (in: Moura, 1994: 13-71). 
demonstra a ligação entre eles. Ela também desce nas festas de Xangô, pois é uma das esposas desse rei.

Podemos sintetizar as danças de Oxum nos seguintes aspectos:

- uma forma circular no começo e, sobretudo, na roda que constrói o espaço sagrado no qual acontecerá a incorporação. Esse movimento circular também é feito com os braços e com a postura do corpo, que é leve e mostra toda a sua coqueteria;

- uma ocupação do espaço durante o transe tranqüila e circular. Ela não se deixa levar para outras partes diferentes de seus círculos na água, aproxima-se das pessoas, mas sempre com leveza, com gentileza, pois ela simboliza a água doce, a água dos rios que desce e leva consigo as coisas do mundo;

— um movimento contínuo, sem paradas, à semelhança da água que desce e tem um andamento constante. Ela é muito paciente, pois um dos elementos da magia é a paciência de saber esperar que o encanto lançado faça seu efeito;

— uma característica de sedução em todas as danças, mas sobretudo na de tomar banho: ela se prepara com movimentos tranqüilos, como se a única coisa importante fosse o de se preparar para o seu papel, o da mulher bonita e que sabe usar esse seu valor.

O ponto fundamental do corpo na dança de Oxum é a bacia, pois todo o movimento do ijexá provém dessa área, que está ligada aos órgãos da sexualidade e da reprodução. Dessa região parte um movimento que toma posse do corpo inteiro numa ondulação tranqüila: liga o alto (a cabeça) com o baixo (os pés).

Quanto ao uso do espaço, sobretudo com os movimentos dos braços, ela o faz horizontalmente e com isso demonstra seu lado social. Ela é uma rainha bonita e também a chefe da sociedade secreta das mulheres, portanto, deve saber como se portar no meio das pessoas.

Seu movimento na vertical parece que se abre, mas tudo sempre se volta para ela. Tem uma expansão do busto para a frente que volta a se fechar outra vez sobre si mesma, seguindo a respiração. Na dança de tomar banho, seu corpo se abaixa até o chão, utilizando então toda a sua verticalidade, pois, sendo água, está em cima e embaixo.

Ela anda numa trajetória contínua, sem movimentos bruscos e sem paradas. E mostra todos os encantos de seu corpo e as possibilidades que tem de oferecer dons e ouro. Seu movimento sugere, sobretudo quanto o comparamos ao de Oiá, uma diferente capacidade de utilização do tempo. Oxum vive o tempo como contínuo e, nesse ritmo eterno, vive a sua respiração como se quisesse atrair todo mundo com o seu movimento do ombro. Ela sabe esperar, enquanto Oiá caminha bruscamente, pára, vai e deixa a idéia de ser uma conquistadora forte e feroz.

De acordo com aquilo que dizem no candomblé, ela é a outra metade de Iemanjá. As duas nos mostram o lado feminino: uma, de ouro, mais visível, a outra, de prata, mais escondida, mais sensível. Tanto é assim que, quando é oferecido algo a Iemanjá, também deve ser feito o mesmo para Oxum e vice-versa, "se não a outra fica ciumando!". 


\section{Iemanjá}

Como dizem lá no Axé, Iemanjá é a mais misteriosa dos orixás: "Ninguém sabe o que ela tem por baixo!". Sua casa está sempre fechada, se abre apenas no ossé, uma vez por mês, e na festa dela, pois "ela não gosta de barulho nem de confusão. O interno parece uma gruta do mar, assim como a outra casa dela no Rio Vermelho também parece uma gruta escondida no fundo do mar!", como me contaram. Ela é a expressão da feminilidade na sua inteireza, é a mãe de muitos filhos e a esposa, pois ela gosta da ordem e da hierarquia.

Podemos sintetizar algumas características dos movimentos de Iemanjá desse modo:

- uma trajetória circular que constrói o espaço sagrado no qual, logo no começo, acontecerá a incorporação. Esse movimento circular é feito também com o corpo inteiro, como se ela mesma originasse essa forma;

- durante a incorporação ela pára e então se move devagar com pequenos movimentos circulares ou como se o corpo virasse uma onda;

- em algumas danças, como o jincá, seu movimento é contínuo como a água que segue o seu curso constantemente. Em outras, no entanto, em seu andar ela pára, retoma força e volta a andar, assim como as ondas quando batem na praia;

- movimentos que descrevem a sua sensibilidade, o seu encanto que é como o da lua cheia, algo de que todos querem se aproximar, mas só poucos conseguem;.

- o uso do espaço é diferente daquele observado para Oiá. Iemanjá, em seu andar, é mais tranqüila do que Oiá e mais pausada do que Oxum. Ela ocupa muito espaço, pois é uma onda do mar. Assim, na primeira de dar rum, ela anda nas laterais, movimentando os braços horizontalmente e empurrando montanhas d'água e seus filhos. Ela dança dois passos para um lado e dois para o outro, mas também se move assimetricamente e, depois de dois passos, ela faz três e pára a fim de retomar a dança.

Quando Iemanjá se locomove como onda, ela ocupa um espaço mais em vertical e também seu movimento é um andar, um chegar para si mesma, é um movimento mais introspectivo, mais ligado a sua interioridade. Ela pára e se prepara para mergulhar no fundo.

Nas danças - com as mãos em forma de concha - , ela utiliza mais o nível inferior do espaço, o que nos remete às profundezas do mar e àquilo que existe lá embaixo. Juntamente com Oxum, ela é uma das grandes mães. Destacamos os níveis baixo e médio, pois ela também representa a fecundidade, a reprodução e, por isso, é mais chegada às partes do corpo situadas na bacia. Por outro lado, ela é muito coração, é caridosa (veja-se a lenda com Omulu).

Contudo, não podemos esquecer que um dos símbolos de Iemanjá é o abebê que, com sua forma redonda, nos lembra a forma da lua cheia, eterno símbolo do feminino. Mas ela também tem um lado mais agressivo, pois carrega uma espada, e o abebê é uma terrível arma de ofensa e defesa que a deusa usa para defender seus filhos.

Os aspectos gerais dos movimentos de Oxum podem ser idênticos aos de Iemanjá, porém me parece que o movimento mais marcante é o horizontal da primeira de dar rum, pois essa coreografia nos fala do lado social e da preocupação de Iemanjá com todos, uma vez que ela é a mãe suprema. Assim, a parte do corpo de onde surge o seu movimento é próxima ao coração. 
Saliento, ainda, que a filha-de-santo chora quando Iemanjá vem; um choro de emoção que demonstra a sensibilidade de Iemanjá.

O seu andar em círculo também sinaliza uma certa conformidade, uma certa ordem, talvez pelo fato de representar a mulher madura, firme, que não necessita mais sair da norma. Iemanjá tem muitas coreografias que demonstram as suas várias facetas, e a cor de prata ajuda a ressaltar a magia e os sonhos que ela leva consigo. Dizem que ela é a senhora dos sonhos.

Ela dança com Oxalá, de quem é esposa, e com seus filhos Oxum, Ogum, Oxóssi e Omulu. Mas, além de uma análise dos passos, que nos falam das histórias míticas, é importante ressaltar o fato de que nas danças de candomblé os fiéis acreditam ser o próprio orixá a se manifestar e, portanto, a amplitude e o fluxo do movimento relatam isto: a transformação interior. No corpo da filha-de-santo não há mais a personalidade dela, sua "presença", mas sim a do seu orixá. Com isso o deus distribui axé à própria filha e à comunidade inteira, contando a sua história mítica. As danças de transe esvaziam o corpo da filha-de-santo para deixar que a forma, a energia do orixá se manifeste e movimente aquela matéria como o orixá o desejar, e, por isso, a qualidade do movimento muda de modo tão evidente.

É interessante notar, ainda, que a relação entre os orixás também é manifestada através dos toques e da energia que é transmitida no movimento. Por exemplo, todos os orixás velhos como Oxalufã, Iemanjá Sabá, Omulu e Nanã — dançam com um ritmo lento e são curvados para o chão, demonstrando a fadiga de andar, pois são muito velhos. Os orixás jovens (ou de qualidade jovem, como Oxaguiã e Iemanjá Ogunté, Oiá e Ogum) dançam sempre com uma postura mais ereta. Os orixás guerreiros (Ogum, Oiá etc) dançam como se estivessem agredindo o espaço e utilizam as diagonais, enquanto os orixás ligados à maternidade (Oxum e Iemanjá) dançam ocupando o espaço de modo mais redondo, mais tranqüilo e sem o uso de diagonais. Xangô e Oxum, por sua vez, dançam utilizando um espaço mais regular, como que simbolizando a realeza. O mesmo acontece com Oxóssi, o caçador.

Queremos evidenciar com isso o quanto é complexa a compreensão da dança ritual que, aliás, deve ser feita sempre como um todo. Não basta uma simples descrição dos movimentos, pois eles não passam de uma moldura para que a energia do orixá se manifeste, levada pela música dos alabê.

Em última análise, essa dança é algo de fortemente encarnado e vivido. A respiração, o ritmo daquele elemento natural vive no corpo da filha-de-santo. Essa é uma experiência tão forte e enriquecedora que merece, verdadeiramente, grande respeito. Numa das cerimônias do terreiro de Oxumarê, por ocasião da festa de Oxalá em 2 de fevereiro de 2000, isso me pareceu claro como cristal. Atrás do Oxalá ia uma Iemanjá, sua esposa, que dançava do mesmo jeito, devagar, e seguia um Omulu - que, mais tarde, teve que ser retirado, pois não conseguia mais nem se mexer. Atrás deles, enfim, dançavam outros casais: Oxóssi e Oxum, Ogum e Oiá, indo sempre devagar, mas com o corpo em posição mais vertical.

Para finalizarmos, as danças de transe são a própria expressão da fé das filhas e filhos-desanto que se deixam tomar e ser conduzidos pelas divindades, cada um com o fluxo e a qualidade 
do movimento do dono da cabeça ao qual corresponde, a fim de reequilibrar as forças cósmicas para si mesmos e para sua comunidade.

\subsection{Uma festa pública}

Para que se entenda melhor o papel da dança de candomblé, acredito ser necessário descrever uma de sua festas públicas, por exemplo, que foi celebrada no Terreiro Axé Opô Afonjá - "As forças de Xangô", em outubro de 1999 —, no Alto de São Gonçalo do Retiro, no bairro de Cabula, longe do centro da cidade. Foi a festa das aiabás, os orixás femininos, realizada quase no final de uma longa série de rituais, que começaram com "As Águas de Oxalá", na última sexta-feira de setembro daquele ano.

Os participantes, em geral, são pessoas ligadas ao terreiro, ou as que o freqüentam ocasionalmente, pessoas do bairro, ogãs (usualmente pessoas ligadas à intelectualidade baiana) ou, ainda, simpatizantes de outros bairros ou de outras cidades.

A estrutura de base de uma festa pública de candomblé segue um padrão fixo, mas, cada ano que passa, alguns detalhes são mudados. Há novos participantes e alguns dos filhos-de-santo mais velhos vão deixando de comparecer por motivo de doença ou de outra natureza. A ausência destes últimos é especialmente sentida, pois são eles os "mais velhos no santo", isto é, os guardiões da tradição e os que detêm maior conhecimento das coisas sagradas: sabem mais cantigas de fundamento que são essenciais à festa.

Cada festa homenageia um orixá em particular. Começa de madrugada, com a matança, sacrifício de animais. Cada orixá tem seu próprio animal sacrificial e sua própria comida. Depois do sacrifício dos animais, todos cantam e oram para o orixá. Em seguida, as filhas do terreiro organizam-se para a preparação da comida sagrada que será oferecida ao orixá — junto com algumas partes específicas daqueles animais sacrificados - e ao público durante um intervalo da festa. A finalidade disso é alimentar a divindade: com o sangue do animal sacrificado, banham-se as pedras sagradas do orixá, os otás ${ }^{159}$, para fortificar as energias e a ligação com o orixá. Esses são rituais que são celebrados apenas para os fiéis da casa. Também nessas ocasiões, os orixás podem descer e dançar no meio dos mortais.

Antes da cerimônia pública, celebra-se o padê ou "despacho" de Exu — ritual obrigatório, que deve preceder a qualquer festa —, realizado no final da tarde. Padê significa "encontro" e, segundo Santos (1977:185-191):

"O pàdé tal qual é praticado no Axé Opô Afonjá é um rito solene e privado, a que só podem assistir as pessoas pertencentes ao "terreiro" ou visitantes de qualidade excepcional. Trata-se de uma cerimônia carregada de perigo, em virtude do poder sobrenatural das entidades que serão invocadas e devido à sua finalidade, que consiste em propulsionar e em manter as relações harmoniosas com essas entidades e em obter ou restabelecer, por meio de oferendas apropriadas, seu favor e proteção".

\footnotetext{
${ }^{159}$ Otá vem da palavra iorubá okutá, pedra.
} 
Depois das orações e dos rituais acima referidos, as filhas-de-santo colocam-se na roda sagrada. Antes de dançar, porém, todos saúdam a entrada principal — provavelmente para reverenciar Exu e os ancestrais - , os tambores, a mãe-de-santo e a mãe-pequena.

Depois do padê, há uma hora ou duas de descanso e, logo depois, a festa começa, primeiro com a entrada da Ialorixá e das pessoas com posições hierarquicamente mais altas no barracão; as abiãs ${ }^{160}$ já estão presentes.

Também o público já chegou para providenciar um bom lugar. Se, ali no meio há alguma pessoa importante, os ogãs, logo encontram um lugar mais apropriado. No momento da entrada da Ialorixá no barracão, o público levanta-se em sinal de respeito e consideração. A Ialorixá senta-se na sua cadeira - que, na África, é um símbolo de realeza - e, quando a roda das filhas é formada, ela sai na frente. Nesse momento inicia-se propriamente a festa. Antes de se porem na roda, as filhas-de-santo fazem as saudações: tocam com a mão o chão e colocam o dedo indicador na testa e atrás da cabeça, assim como também fazem na entrada principal, na frente dos tambores e diante da mãe-de-santo e da mãe-pequena. Fogos de artifício são soltos a fim de indicar que a festa está começando. Todo esse complicado ritual de saudação é feito com grande seriedade e respeito, segundo um ideal de postura africano, que foi muito bem descrito por Thompson (1974: 43).

As filhas-de-santo pedem a bênção também aos ogãs. A grande roda sagrada forma-se e o xirê pode começar. As filhas e os filhos-de-santo presentes dançam em círculo em sentido antihorário, cantando um mínimo de três cantigas para cada orixá. No Axé começa-se por Ogum, pois Exu já foi saudado à tarde. A "roda" tem uma ordem iniciática: as ebômis, as filhas mais velhas, abrem a roda, enquanto as recém-iniciadas, as iâos junto com as abiãs, a fecham. Participam da roda de trinta e cinco a quarenta fiéis, na maioria mulheres. São poucos os filhosde-santo, cerca de dez.

A orquestra é formada por três atabaques: o rum (o maior); o rumpi, (o médio), o lé, (o menor), e o agogô, um instrumento africano feito de duas campainhas de ferro. Atrás da orquestra, um grupo de meninas acompanha a festa, todas cantando e dançando junto às filhasde-santo, num crescendo de alegria e entusiasmo. O xirê pode durar de meia até duas horas. Nessa festa, prolongou-se por mais quarenta minutos. O xirê, segundo o orixá dono da festa, segue uma ordem diferente para chamar as divindades. A ordem preestabelecida seria a de saudar antes de tudo Exu, no padê e abrir o xirê com Ogum, fechando com Oxalá, mas no Axé Opô Afonjá, não se canta para Oxalá, porque já foi evocado no final do padê. Na festa que descrevo, foi essa a ordem seguida. Há um ciclo de danças e cantigas no qual as filhas e os filhos-de-santo olham para o centro do barracão, chamado "roda". Há "roda" para Xangô, para Oxóssi, para Oxalá, para Oxum e para Iemanjá.

Primeiro, canta-se para os orixás masculinos. Inicia-se com cantigas de Ogum, o guerreiro. Ele abre o caminho e dança como se se preparasse para guerrear e cortar o mal. Em seguida, canta-se para Omulu, o dono da terra. Ele dança curvado para o chão e, quando o

\footnotetext{
${ }^{160}$ Abiãs (os que vão nascer, em iorubá) são os aspirantes, os que estão situados na escala mais baixa da hierarquia religiosa e que ainda não se iniciaram.
} 
atabaque manda dançar "quebrando"161, flexiona as pernas e movimenta os ombros. Depois, Oxóssi, o caçador, se movimenta como se tivesse nas mãos arco e flechas e estivesse procurando caça. O ciclo de dança é concluído por Oxumarê, o arco-íris, que é louvado somente nas festas de Xangô e Omulu. Oxumarê dança com os dedos indicadores levantados como se fossem duas cobras. A Xangô pertence um ciclo particular de danças e cantigas no qual todas as filhas giram, olhando para o centro do barracão onde está o fundamento da casa. Em seguida, é a vez das aiabás: Oxum, vaidosa, dança, abrindo e fechando o ângulo dos cotovelos, expressa a fluidez da água doce com movimentos pequenos. Depois vem Obá, dançando como Xangô, com uma mão na frente; a roda olha para o centro. Oiá dança como Ogum, cortando qualquer coisa na sua frente e pondo as mãos como se estivesse afiando as suas espadas. Euá, leve e fluida, movimenta os braços como se estivesse enrolando alguma coisa e a jogasse fora para os outros. Iemanjá, a água salgada, dança expressando o movimento da onda do mar e também levanta as mãos como se afiasse espadas. Quem fecha a roda é Xangô, que se move abrindo e fechando os ombros. Ele apresenta-se, assim, como um rei. Os movimentos simbolizam a característica particular de um evento mítico de cada orixá. Uma das danças de Xangô, por exemplo, em que as mãos ficam juntas na frente do corpo e voltadas para o chão, refere-se à lenda na qual ele se joga debaixo da terra e desaparece para sempre, virando um orixá.

Cada vez que cantam para um orixá, as filhas-de-santo e os devotos tocam a terra e levam a mão direita à testa e atrás da cabeça. Esse é um gesto de respeito e de saudação.

Somente após terem cantado para os orixás, entoam uma cantiga especial com a intenção de chamar o orixá dono da festa, para que ele se manifeste. Segundo Lühning (1990b: 118):

"(...) as cantigas para chamar o santo variam de um orixá para o outro, ou conforme certos grupos ou família de orixá. Outras cantigas são mais gerais e têm um poder sobre as filhas-de-santo de todos os orixás. Estas são as mais temidas e menos usadas."

Começam, então, as incorporações, a virada, a caída no santo, enfim, as manifestações dos orixás. Primeiramente, as fiéis pertencentes ao dono ou dona da festa e depois todos os outros que têm ligações ou relações mitológicas com ele. O público e os devotos, agora, participam sempre mais envolvidos, acompanhando com batidas das mãos e gritando a saudação do orixá principal da festa num entusiasmo crescente.

São várias as qualidades de cada orixá presentes na festa, umas dez Oiá, por exemplo, rodam no barracão, alcançando todas as direções, cada uma com um qualidade de dança diferente, o que demonstra suas diferentes personalidades. Há uma Iansã muito forte que movimenta o corpo todo com impulsos freqüentes e com paradas rápidas. Há uma outra, mais tranqüila e harmoniosa que parece voar. Uma outra ainda, caminha altiva e orgulhosa no espaço. $\mathrm{Na}$ festa aqui descrita, para as aiabás, manifestam-se também as divindades que têm ligações com elas como Ogum, Oxóssi e o esposo de todas, o querido Xangô..

A incorporação é bem visível: o possuído perde o seu eixo e, tremendo, tapa o ouvido, fecha os olhos, perde a noção de direção até que, rodando em volta do próprio eixo, incorpora

\footnotetext{
161 "Quebrar" é usado aqui para indicar uma variação do ritmo, quando se dança inclinado para o chão, movimentando os braços como se estivesse balançando os ombros. O mesmo se dá em vários toques.
} 
completamente o orixá. Várias são as filhas-de-santo que rodopiam muitas vezes, com os braços abertos, como se formassem um sorvedouro. O momento no qual o orixá entra no corpo da filha é de grande concentração. Os movimentos são menores, os olhos estão fechados e os rostos têm uma expressão de interioridade. Para poderem receber o orixá, essas filhas-de-santo já passaram por um longo aprendizado.

A postura do corpo muda, o santo o deixa mais imponente e mais fluido, com uma expressão muito intensa na fisionomia. Os olhos ficam fechados e os lábios, alongados, dando a impressão de uma máscara. $\mathrm{O}$ corpo e o rosto se transformam completamente numa plasticidade de grande força e intensidade. A máscara do rosto tem duas funções nesse contexto: de um lado, é um elemento protetor perante a divindade, porque o homem não pode ver o numinoso sem algum tipo de filtro, seria muito perigoso. Por outro lado, é símbolo da transformação que se verifica na dança sagrada.

O encontro com a divindade desenvolve-se em etapas progressivas, porque a força do sagrado pode ser forte demais e interromper o processo de conhecimento inscrito no ritual. As mãos são colocadas para trás e sobre o quadril, caso a filha seja "velha no santo", enquanto o corpo oscila e o possuído transfere o peso corporal de uma perna para a outra. De vez em quando, o orixá treme na região das costas, com um movimento muito particular, chamado jincá.

Houve outras incorporações, mas os outros orixás foram despachados. Nesse momento, não é mais o fiel, porém o próprio orixá quem está presente. O orixá aguarda a ajuda de uma equede, que auxilia as filhas-de-santo em transe e as ampara a fim de que não caiam. A divindade espera com paciência a sua vez de ser ajudada, ficando em pé, com as pernas levemente flexionadas, ou andando para o barracão. A equede enxuga-lhe o suor, levando-a à camarinha para vestir a roupa do orixá.

O orixá da equede deve se harmonizar com o da iaô a quem auxilia. A equede não entra em transe e, geralmente, não usa vestido especial. Veste uma roupa branca simples ou, como no terreiro em foco, uma roupa estampada com as cores do orixá dono da festa, um modelo que lembra um vestido africano. As equedes tiram os sapatos do possuído e tudo o mais que não pertence ao orixá, como relógios e brincos, e amarram o ojá, o turbante, de forma diferente, fazendo um laço atrás para as "santas mulheres" e amarrando um laço sobre o ombro, para os "santos homens", de modo que deixam bem claro que, naquele momento, não é mais a filha-desanto quem dança, e sim o orixá.

Depois de cantar para o dono da festa, cada orixá presente e manifestado é saudado com a cantiga chamada primeira de dar rum. Tanto a dança quanto essa cantiga são chamadas assim porque são coordenadas pelo atabaque principal, o rum, de modo bastante peculiar. Dar rum ao orixá significa deixar o rum tocar especialmente para os orixás manifestados. A função das primeiras de dar rum é a de apresentar o orixá ao público, às irmãs-de-santo e aos atabaques. Nessa primeira parte, todas as danças têm coreografias parecidas.

Com o ritmo chamado avamunha, segundo uma informante: "os orixás são levados ao roncó, camarinha ou quarto sagrado, saindo pela entrada principal, junto com alguns ogãs e outros ajudantes para serem vestidos com os paramentos litúrgicos". Durante o intervalo, no qual 
os deuses são vestidos, o público é chamado a comer a comida especial do orixá dono da festa. Em nosso caso foram várias as comidas sagradas para os orixás e havia também uma bebida chamada aluá ou aruá, feita com suco de abacaxi deixado a fermentar com açúcar mascavo, água e gengibre. É uma bebida muito doce. A essa altura, algumas pessoas, entre as abiãs e as iaôs, formaram novamente a roda sagrada. Essa é uma oportunidade para elas praticarem as danças sagradas.

Uma nova queima de fogos, então, anuncia a chegada dos orixás paramentados. As divindades entram por uma porta do lado direito da Ialorixá, acompanhadas pelo som de uma outra cantiga especial, com a qual se pede licença para entrar no barracão. São treze orixás conduzidos pela iaquequerê, que toca o adjá, um instrumento particular que tem a função de chamar as divindades. Abre o cortejo um lindo Ogum, vestido de verde e azul com um mariô e carregando na mão a sua espada. Atrás dele vêm os outros orixás, Oxóssi e as Oiás, com roupas cor-de-rosa e, por último, vêm uma deusa vestida de branco, a Oiá Igbalé, Oxum, vestida de amarelo e ouro, e Iemanjá de branco e azul.

As aiabás, ao se apresentarem ao público, têm que expressar a própria majestade e a própria força vital. Elas são acolhidas com uma seqüência de três cantigas puxadas pelos ogãs. Movem-se em círculo dentro do barracão. Na última das três danças de apresentação, entregamse flores ao orixá dono da festa. Iniciam-se, desse modo, as danças de possessão junto com as cantigas, ambas contam episódios míticos da vida do orixá, como já sublinhamos anteriormente. O número de cantigas dirigidas a cada orixá depende do quanto o orixá dança "bonito". Às vezes, quando se canta para o dono da festa, como relata Lühning (1990b: 118):

"(...) cantam-se cantigas com fundamentos tão profundos que forçam as filhas-de-santo de outros orixás a caírem no santo. Essas são chamadas "cantigas de fundamento".

Os orixás, nesse momento, dançam episódios de suas vida sozinhos ou, se as cantigas mandam, juntam-se aos outros orixás em coreografias de grande beleza e fascínio. São exemplo disso as coreografias de Oiá lutando com Ogum ou guerreando junto de Xangô.

Ao longo do ritual, alguns dos ogãs da casa oferecem dinheiro, que é passado sobre a cabeça do orixá escolhido e, em seguida, deixado na frente dos atabaques, simbolizando um hábito africano.

Às vezes, são oferecidas ao público pequenas lembranças da festa. Depois que todos os orixás dançaram, são despedidos com uma cantiga especial a cantiga de maaló (despedida). Com ela, cada divindade vai embora, conduzida pela iaquequerê enquanto os atabaques tocam. A cerimônia acaba assim. O esquema das festas segue esse padrão em quase todas as casas tradicionais. Encontram-se, contudo, variações no xirê, nas cantigas e nas danças, conforme o fundamento da casa.

\subsubsection{As festas de Oiá, Oxum e Iemanjá}

Só para acrescentar, há também uma festa para cada aiabá que não irei transcrever, mas que mencionarei porque é de grande importância ritual. Logo depois da festa das aiabás, na 
primeira quarta-feira seguinte, ocorre a festa de Oiá. No domingo seguinte, fazem uma festa para Oxum e no outro Domingo, para Iá, Iemanjá.

A festa de Oiá tem um fundamento muito importante ligado a Oiá Igbalé, qualidade de Iansã relacionada com os eguns. Para isso, os ojés ${ }^{162}$ da Ilha de Itaparica vêm ao Axé para homenagear Oiá. Eles entram pela porta principal depois de Oiá ter dado o rum com as varetas deles, as exam, e um galho de mario ${ }^{163}$. Depois de entrarem, colocam-se de costas para os tambores e, ajoelhando-se, cantam para Oiá Igbalé e, após terem entregue o mariô vão no $i^{\prime}{ }^{164} \mathrm{e}$ deixam lá esses exam. Nessa festa, as filhas de Oiá, que no período da minha pesquisa eram quatorze, entram em transe com cantigas de Oiá.

A festa de Oxum é no Domingo. É caracterizada pelo fato de ser organizada em honra de Mãe Senhora e por isso possui uma obrigação especial. Três ebômis vão a pegar uma atalha com água que é posta aos pés da Oxum da casa. Toda as filhas-de-santo devem beber dessa água e, enquanto isso, uma cantiga acompanha o gesto ritual dizendo:

"Estou bebendo a água de minha mãe, saúde!".

A seguir serão descritas algumas cantigas da roda de Oxum:

A rí be dé ó omi ro a ará wa omi rò

A rí be dé ó omi ro a ará wa omi rò

A rí be dé l'omi ó, omi ro a ará wa

Omi ró ó, a rí be dé l'omi ó,

Omi ro a ará wa omi rò

(Nós vimos o brilho da sua coroa, a água pingou em nós, em nossos corpos água sagrada. Nós vimos o brilho da sua coroa, a água pingou em nós, em nossos corpos água sagrada. Nós vimos o brilho da coroa na água, e a água pingou sobre nós, em nossos corpos a água sagrada, nós vimos o brilho da coroa na água, a água pingou sobre nós, em nossos corpos a água sagrada.)

A Segunda cantiga na roda é:

Igbá iy' awó igbá si Osun ó réwà,

Igbá iyàwó igbá si osun ó réwà,

Awa sin e ki igbá réwá réwà,

Igbá iyáwó igbá si osun ó rewà

(Ibá iauô ${ }^{165}$ é para Oxum no dia do seu casamento. Nós a cultuamos, a formosa noiva que recebeu uma linda cabaça, a cabaça é para a noiva Oxum,

\footnotetext{
${ }^{162}$ Os ojés são os sacerdotes iniciados no culto dos eguns.

${ }^{163} \mathrm{O}$ mariô é um galho de folha de palmeira desfiado, utilizado seja por Ogum, seja pelos ojés. Serve para afastar os espíritos dos mortos e os maus fluídos. Costuma-se colocá-lo também na entrada da casa.

${ }^{164}$ Lugar dos ancestrais.

${ }^{165}$ É uma cabaça contendo tecidos, roupas, alimentos e outros pertencentes como presente para a noiva.
} 
que estava linda no dia do seu casamento.)

Dança-se aqui, como sempre em todos os toques batá, como descrevi nas danças para Obá: ombro contra ombro e olhando para o centro do barracão, com uma movimentação parecida àquela do xirê, mas agida com muito mais ênfase e com um movimento do corpo para trás mais amplo, como se o corpo todo se dobrasse. Os ombros mantêm esse movimento rotatório.

No domingo seguinte, ainda temos a festa de Iá, como é chamada Iemanjá assim no Axé, sendo considerada da nação grunci. Infelizmente, as danças dessa nação parecem ter sido esquecidas, uma única vez me foi dito que são danças feitas com uma postura dobrada e as mãos sobre os quadris. Aqui, também, os orixás foram chamados com a roda de Iemanjá. A posição que os corpos ocupam na roda é semelhante às demais rodas, enquanto o movimento das mãos é executado lançando-se primeiro uma e depois a outra mão para o centro com muita ênfase e força.

\section{Laderibo akalose iemanjá}

Adaribo

(Nessa cantiga Iemanjá é já velha e procura algum de seus filhos, mas não encontra ninguém.)

Nessa festa não há uma obrigação específica visível ao público, como acontece nas outras duas. Ocorrem, no entanto, rituais mais secretos, exclusivos às mais "velhas da casa".

Há uma outra cerimônia, no décimo segundo dia do ciclo das festas de Xangô, para um tipo de Iemanjá chamada Iamassê, considerada a mãe mitológica de Xangô. Nesse dia todo mundo usa roupa branca em homenagem a esse orixá. Esse orixá não incorpora em ninguém.

O orixá cria o movimento, como o de se projetar para fora, no espaço e no mundo: o corpo movimenta-se num continuum no qual espaço, tempo e energia interagem constantemente. 


\section{Capítulo 9:}

\section{O COTIDIANO DAS MULHERES DE CANDOMBLÉ}

\subsection{Introduzindo o problema, descrevendo casos}

No Axé mora um grande número de mulheres sozinhas. Algumas vivem na casa de Oxalá, outras moram com as respectivas famílias em casinhas, construídas desde muito tempo e outras chegam só no período das festas. As que moram na casa de Oxalá são as que cuidam mais das obrigações e que se aprimoram ao longo das feituras. Já as que moram com as famílias, normalmente têm uma vida particular, paralela àquela do candomblé. A seguir relatarei algumas histórias de vida e entrevistas feitas com algumas mulheres do candomblé.

\section{Mãe Stella de Oxóssi}

Mãe Stella é uma mulher anciã de classe média. Formou-se em enfermagem e trabalhou vários anos. Não têm filhos carnais, mas muitos espirituais. Mora no terreiro, numa casa particular, em companhia de uma ebômi e circundada pelo afeto de seus filhos-de-santo e familiares. É certamente a mãe-de-santo mais conhecida no Brasil e também no exterior. Suas posições políticas e religiosas são apreciadas no mundo ligado às religiões africanas da diáspora e aos problemas ecológicos, tendo se tornado, por isso, uma importante personagem política.

Lembro de um depoimento feito em 2000 num encontro no Parque da Cidade, em Salvador, junto com outros grupos sobre a questão do rio São Francisco, no qual ela falou com muita simplicidade sobre o problema e mostrou o mundo dos moradores e dos trabalhadores 
daquele rio como um todo. Conseguiu passar a idéia de um mundo de pessoas, animais e plantas que vivem ao longo de suas margens, fazendo quase uma cosmovisão da situação. Conseguiu organizar os atores e o rio numa ordem natural, com muita sabedoria e simplicidade, o que deixou as pessoas refletirem sobre o assunto. Ela é constantemente convidada para seminários, congressos e encontros afins para falar de religião ou sobre as relações raciais.

Seu dia-a-dia é muito fatigante. Os telefonemas dos fregueses e amigos começam de manhã cedo: lá pelas 8 horas as pessoas chamam e vai assim até umas 9.30, quando ela sai, seguida pelo seu fiel cachorro, até a casa de Xangô, onde ela olha os búzios e recebe as pessoas. Dependendo dos clientes, ela fica ali até as 13 horas ou mais, quando volta para casa, e recomeçam os telefonemas. De tarde, tira um descanso para reiniciar lá pelas 16 horas ou 17 horas.

Ela também é uma pessoa muito organizada e tenta encaixar todo mundo em sua agenda. Vi muitas vezes Mãe Stella preocupada por não poder ajudar alguma pessoa. Trata bem tanto as pessoas importantes quanto as mais comuns e se explica sempre de um jeito simples. Suas palavras passam sempre mensagens de procura de um equilíbrio interior pessoal para as pessoas se encontrarem.

Susanna: "Mãe Stella, como a senhora faz para receber tanta gente, todos os dias? "

Mãe Stella: "Isso é muito cansativo, mas as pessoas precisam. O mundo é difícil e as pessoas são despreparadas para a vida!"

S: "A senhora acha que é o mundo difícil ou difíceis são as pessoas?" (risadas).

M: "Os dois, mas até que uma pessoa não se acha, não entende quem ela é, e é difícil enfrentar a vida. A gente tem que procurar um equilíbrio. Orixá é equilíbrio e quando a gente o consegue tem que trabalhar para mantê-lo".

S: "Parece que este mundo está traumatizando sempre mais as pessoas, não é?"

M: "As pessoas são divididas entre muitas coisas; tudo é sempre mais corrido; é dificil se manter em pé. Mas a gente tem que dar um jeito de se encontrar e de fazer as próprias obrigações de coração leve. Não adianta fazer trabalhos sem se concentrar, a força não vem!. As pessoas precisam entender que têm que encontrar a força dentro de si mesmas e continuar. Às vezes a gente gostaria de ajudar mais, dizer uma palavra, mas não pode; cada um tem seu caminho e seu destino. Mas a vida continua. Se a gente tem uma relação boa com o orixá, a gente enfrenta; é questão de fé também!".

S: "Mãe Stella, parece que as pessoas depois da iniciação mudam de expressão, mudam a forma do corpo..."

M: "Eh! A iniciação conserta as pessoas! Cada um com seu caminho; então, se uma pessoa segue em frente com as obrigações, é claro que muda interna e externamente. Os seres humanos são um todo."

Tivemos que parar aqui a entrevista, pois procuravam-na: tinha uma pessoa precisando de sua ajuda. 


\section{Mãe Amália}

É uma senhora negra, de classe média-baixa, gordinha e sempre de bom humor, originária da Liberdade ${ }^{166}$. Trabalhava como cozinheira. Casou-se quando tinha 20 anos e teve cinco filhos, entre os quais uma mulher. Os filhos e os netos vivem com ela, de modo que em sua casa moram uns dez adultos, mais os seis netos. Além da família restrita, moram também várias filhas-desanto em períodos mais ou menos longos. Em seu terreiro, há um grande número de moças jovens iniciadas, cerca de quinze, que vivem constantemente no terreiro e que são orientadas pela mãe-de-santo. Mãe Amália foi iniciada há 23 anos. Ela é filha de Oiá, e agora tem 36 anos de feita. Tornou-se mãe-de-santo, mas não queria, pois isso comporta muita responsabilidade.

Seu terreiro fica na mesma área onde mora: perto da Av. Vasco da Gama, em Salvador. Trata-se de uma casa particular de três andares, com um quintal na frente e um outro atrás. Ali fica o barracão e, ao seu redor, as casas dos orixás, dos eguns e mais à frente, a de Exu.

Trabalha em casa nos afazeres domésticos e tem uma intensa atividade como mãe-desanto do bairro. Sua vida se divide entre as obrigações religiosas e familiares. O limite entre a vida privada e os deveres religiosos é muito sutil, pois as filhas-de-santo vivem com ela.

A vida de Mãe Amália começa de manhã cedo: quando não tem obrigações, ela se levanta lá pelas $6.00 \mathrm{~h}$ e inicia o seu dia ou lavando roupa ou preparando a comida para o almoço. Logo os outros componentes da família acordam e o dia começa. Já de manhã chegam os fregueses ou alguém do bairro passa simplesmente para dar um alô. Mãe Amália é a referência do bairro ou, pelo menos, de muitas pessoas da área. Tornou-se a conselheira de todo mundo e o seu jeito maternal e acolhedor a revela como uma pessoa cheia de sabedoria e humanidade.

Tem sempre alguém que chega para bater um papo ou para que essa mãe-de-santo olhe os búzios. As pessoas esperam para serem atendidas, acomodadas no pequeno quintal, embaixo de um pé de iroco muito grande e frondoso. Chegam e se sentam. O tempo, nos terreiros, não é o mesmo que o da sociedade de fora, ali as coisas acontecem segundo uma outra concepção do tempo $^{167}$. Portanto, um freguês pode esperar desde 30 minutos até duas horas ou mais. Enquanto ficam no quintal batendo papo com alguém do terreiro, a mãe-de-santo aproveita para acabar com outros afazeres: a preparação de algum ritual para alguém ou algo em casa etc. Como pude notar, as tarefas privadas e religiosas se entrelaçam em continuação.

Lembro de uma vez quando chegou uma mulher que tinha sido espancada pelo marido e fugido de casa. Mãe Amália mandou que alguém tomasse conta da mulher. Ela tomou um banho de folhas para se acalmar e depois teve uma longa conversa com a mãe-de-santo.

A mãe-de-santo passou-lhe conselhos e a sua mesma experiência com grande dignidade e, apesar da mãe-de-santo já ter-lhe falado para abandonar o marido e para se iniciar, não tomou nenhuma postura de acusação por a mulher não ter cumprido sua obrigação. Mãe Amália

\footnotetext{
${ }^{166}$ A Liberdade é um dos bairro populares de Salvador onde se localiza a famoso bloco Ilê Aiyê.

${ }^{167}$ Sobre o conceito do tempo no candomblé, veja-se Prandi (2001a).
} 
demonstrou uma grande compreensão e, com simplicidade, contou uma lenda na qual encaixou a vida daquela mulher. Ela, junto com seus dois filhos, passou a viver no terreiro por um bom tempo, uns oito ou dez meses, até encontrar um canto para si.

Essa senhora manteve várias conversas com a mãe-de-santo que procurou realmente ajudar-lhe, inclusive economicamente e em sua iniciação, que foi organizada dois meses depois daquele acontecimento.

Depois de resolver casos urgentes como este que acabo de contar, presenciei um outro, o de um homem "irradiado" de Exu que foi acalmado só depois de duas horas de rezas e conversas com a divindade. Este fato aconteceu numa tarde de domingo: muitas pessoas estavam presentes no terreiro, estavam batendo papo quando chegou um rapaz bêbado e com o rosto quase deformado, acompanhado por dois homens. A mãe-de-santo rapidamente pôs todo mundo dentro de casa e ficou de fora, em companhia do rapaz, com os ogãs e algumas das sacerdotisas mais velhas. Somente depois de duas horas foi que ele se acalmou e, então, a gente pôde sair.

Mas, além desses casos mais pesados, a mãe-de-santo cuida de todo mundo: os filhos carnais, os espirituais e de quem a procura. Toma a sua agenda e organiza os rituais para outros filhos-de-santo ou fregueses novos. De modo que, a cada semana, ela tem pelo menos uns dez rituais de limpeza para pessoas novas.

Usualmente, de manhã arruma a casa e organiza o seu dia inteiro. Sai para a feira quando já é de tarde. Geralmente, Mãe Amália vai para São Joaquim, perto do porto dos ferry-boats, pois ela diz que ali as verduras são mais frescas e as galinhas, mais baratas. Mas ela freqüenta também a feira de Sete Portas, perto da Cidade Baixa, onde conhece várias pessoas e gosta de ir para conversar e se distrair um pouco, lembrando dos antigos moradores da Liberdade. Volta já de tardinha, por volta das $5.00 \mathrm{~h}$ ou $6.00 \mathrm{~h}$ horas, e novamente encontra alguém do bairro ou de outro lugar que chegou para conversar com ela ou receber um conselho. Às vezes até os seus próprios filhos ficam esperando para falar com a própria mãe.

Mesmo nos dias mais tranqüilos pode acontecer algo como, por exemplo, uma tarde em que chegou uma moça em companhia de sua filhinha de cinco anos para se preparar para a obrigação do dia seguinte. De repente, ouviu-se o ilá da sua Iemanjá que parecia uma melodia. Todo mundo parou e duas equedes se foram para tomar conta da moça, mas a filha já tinha aprendido o que fazer. A pequena já tinha descalçado os sapatos da mãe, assim como tirado seus óculos, e estava indo ao barracão para deixar ali esses objetos, enquanto o orixá andava pelo quintal.

Nos dias de festas ou de obrigações grandes há sempre muita euforia e muito trabalho a se fazer. Todas as atividades particulares ficam para um segundo plano e a mãe-de-santo arca com toda a responsabilidade pela festa. Tudo depende dela, desde as coisas mais importantes até os pequenos detalhes. As filhas-de-santo e os ogãs pedem tudo para ela, a fim de terem certeza de sua aprovação e da sua satisfação. São coisas simples, como os enfeites do barracão que as pessoas já fazem há anos, mas tudo deve ser revisado pela mãe-de-santo e feito como a tradição manda. E é aí que cada filho e filha-de-santo tem a sua responsabilidade e o seu "o que fazer".

Mãe Amália: "E aí, querem saber o quê?" 
Susanna: "Como é que a senhora consegue passar essa calma para as pessoas, até aos mais agitados?"

M: "A gente dá um jeito e tem cada cabeça, dificil para consertar!"

S: "Mas, por exemplo, aquele dia que chegou aqui aquele bêbado, como consegui acalmá-lo?"

M: "Aquele foi um negócio sério! Ele não queria, porque não queria de jeito nenhum se acalmar! Mas a gente fez um trabalho e depois ele veio e indo conversando, ele se iniciou e agora ele trabalha e voltou para casa."

S: "A gente viu chegar aqui um bocado de pessoas cheias de problemas e a senhora consegue conversar com todos, dar uma força para todos!"

M: "Você viu como é, não é? Bem, sabe... a gente aqui já viu de tudo, então é muita experiência que a gente tem! E eu também já passei cada coisa! Mas as pessoas têm que se apegar ao próprio orixá. É ele quem nos ajuda nas situações mais difíceis. É ele quem nos avisa, alerta e ampara; então, é ele o nosso bem mais precioso. Tento passar isso aos meus filhos. As pessoas acham que candomblé é aquele negócio mágico. Candomblé é religião e como tal precisa de esforço e de muito amor; sem amor a pessoa não é nada. Aqui a gente aprende a respeitar os outros. Quando ouço algo desagradável sobre alguém, falo logo: ninguém pode julgar ninguém; somos todos seres humanos!"

\section{Ebômi Raiulda, filha de Xangô}

É uma mulher negra, de 45 anos, redondinha e muito simpática. É formada em artes, mas já aposentada. Ela mora com a mãe e não tem família própria. Tem muitos amigos e gosta da farra. Ela é reconhecida por sua forte intuição e pelo conhecimento de rituais e trabalhos, sobretudo, os de limpeza. Ela anda bastante nas festas até de outro terreiros e atualmente trabalha muito pelo Axé, pois recebeu um cargo importante.

Susanna: "Podemos falar um pouco das mulheres e do que significa ter sido iniciada?"

Ebômi Raiulda: "Olhe, a primeira coisa para uma mulher é ter um trabalho, ser independente do marido, que eles não prestam, e ter filhos! Mas primeiro, ser independente!"

S: "Por que? Você acha que uma mulher não pode ficar só em casa, tomando conta da família?"

E: "Olhe, eu acho que sim, mas já vi tantas coisas, e os homens não prestam; então, por que a gente tem que ficar brigando com um homem que talvez não dá nem comida? Acho melhor ter um trabalho e depois ir à luta para ter o nosso prejuízo!"

S: "Você não tem confiança nos homens?"

E: "Eu? De jeito nenhum! Já vi tantas coisas e não só entre os pobres; eles só pensam em curtir, não prestam! Quanto choro eu já ouvi e quanto eu já chorei, para quem? Para um mentiroso?"

S: "E você acha que fazer o santo ajuda a gente?" 
E: "Claro, não tenho dúvidas; a gente sabe ficar mais com a gente. Aprendemos a ter mais dignidade. É dificil, tenho que dizer, mas é muito bom, é muito bom mesmo!"

S: "A senhora percebe a ajuda do orixá todos os dias?"

E: "Eles estão aqui conosco todos os dias. Até mesmo agora estamos rodeados. Quando preciso de algo eu me concentro sobre algo do meu orixá, ai vem a resposta! Eles nos ajudam demais, demais!"

\section{Ebômi Elvira}

Essa é uma senhora negra, de uma das famílias mais importantes da Bahia, quanto à ancestralidade. Ela é filha de Oxalá, mas tem uma forte ligação com Oxum. Foi feita há 54 anos. Era enfermeira. Trabalhou por dez anos no Rio de Janeiro, onde tinha alcançado uma boa posição financeira. Mas, ao ficar sozinha, veio para o Axé Opô Afonjá e dali não saiu mais. Ela tomava conta de uma das velhas ebômis de Oxalá que morreu há um ano atrás. É uma pessoa muito especial, inteligente e esperta, que teve contato com muitas personalidades e isso se deu porque ela sabe conversar com todo mundo.

Ebômi Elvira aconselha quem a procura e, apesar do seu jeito, no começo tímido, ela logo se abre e ajuda sempre com uma palavra ou contando uma lenda.

Susanna: "O que a senhora acha da questão da mulher no candomblé?"

Ebômi Elvira: "Eu acho que o candomblé deu uma grande oportunidade para as mulheres. Você conhece a história das escravas, então? Elas mantiveram a sua força através do candomblé, se apegando ao orixá, amando-o, porque sem amor, não há nada! ".

S: "Mas, a senhora acha que a tradição toda foi mantida através das mulheres?"

E: "Claro que teve a ajuda dos homens, já ouvi falar desta história do matriarcado até no encontro ${ }^{168}$ aqui no Axé. As mulheres fazem algo e os homens outras coisas, é isso. Mas na nossa tradição a liderança se passa via feminina. É questão de ancestralidade e do fato de a mulher ser mãe. Na vida do dia-a-dia, as mulheres conseguiram muito: trabalho, oportunidades, curtição; porque elas são independentes e fortes para enfrentarem aquilo que já foi e o presente. As pessoas acham que candomblé é magia, vêm para cá, fazem um ebó e pronto! Não é isso. Tem que seguir a regra, a disciplina, pois só se recolhendo de vez em quando a gente ganha força e vai à luta!".

S: "A senhora está dizendo que as pessoas precisam de recolhimento de vez em quando?"

E: "Mas é isso mesmo, quando a pessoa não se sente bem, ela vem para cá, pega um pouco de axé, fica aqui uns dois dias e com certeza vai ter resposta para os seus problemas."

S: "Uma última pergunta, ebômi, a senhora acha que as pessoas se transformam depois da iniciação?"

\footnotetext{
${ }^{168}$ Referência ao encontro de alabês que se realiza todos os anos no Axé Opô Afonjá. No seminário de 2000 houve uma seção sobre o matriarcado no candomblé.
} 
E: "A iniciação é uma grande experiência. E não só os momentos do recolhimento. É uma viagem longa que dura sete anos e, depois, a vida toda a gente aprende. As pessoas aprendem a experienciar o próprio orixá e a se ligar com ele para serem ajudadas no dia-a-dia. Que a vida é esta, viver o dia-a-dia, fazendo as coisas que o destino nos apresenta"

Conforme as entrevistas acima, pudemos observar a clareza na exposição das falas referentes ao lado cotidiano da vida e também ao religioso.

\subsection{As mulheres como seres-no-mundo: o valor da experiência}

Conforme os depoimentos anteriormente apresentados, parece que as mulheres de candomblé adquirem ao longo do tempo uma profundidade e uma compreensão da vida que vai muito além do visível. Quando uma sacerdotisa torna-se mãe-de-santo, sua vida será praticamente dedicada às obrigações com os orixás e à ajuda às pessoas.

As mulheres que se tornam mães-de-santo conseguem sempre menos ter uma vida particular ou, colocando de outra maneira, suas vidas privadas ficam estreitamente relacionadas ao lado religioso. Desse modo, também aquelas que já passaram pelas obrigações, tornam-se conselheiras e consoladoras das pessoas, pois tiveram tantas experiências próprias de vida e já escutaram tantas histórias alheias que, por isso, conhecem a fundo o coração humano.

Parece que as mães-de-santo conseguem encaixar as experiências, inclusive as de sofrimento, numa ordem que deve ser alcançada por meio das várias obrigações. O mundo do candomblé é um mundo de obrigações, de deveres, de disciplina. Detrás dos sorrisos das sacerdotisas se esconde uma firme procura interior e uma fé inabalável. Como uma vez falou Mãe Stella: "Para ser livre precisa passar através das obrigações!".

Elas não são mais donas de suas próprias vidas apenas, mas, pelo fato de saber mais, de não ser mais ingênuas, têm a obrigação - como me explicaram - de fazer a caridade. As pessoas de fora não sabem, então é necessário entender isso e ajudar como se pode.

As outras mulheres que não são mães-de-santo não têm obrigações tão pesadas, porém, além do trabalho e da família, devem voltar ao terreiro periodicamente a fim de ajudar na preparação dos rituais. As experiências da iniciação tornam-se um pacto indestrutível entre elas, o orixá e a comunidade, porque no futuro um pode precisar do outro. Cria-se, então, uma corrente na qual quem foi ajudado deverá ajudar depois. A iniciação é uma experiência prática, vivida no corpo e que será lembrada para sempre, pois foi incorporada na carne e, por isso, seu trabalho principal é dar valor à vida, à memória da ancestralidade, ao orixá.

Numa sociedade na qual essas mulheres foram historicamente vítimas da escravidão ${ }^{169}$, tornaram-se "mulheres que sabem" diante de um mundo de pessoas que "não sabem". Elas dão valor ao seu orixá, pois, conforme Mãe Stella, "o orixá é dentro de nós!"; elas podem se tornar o próprio orixá e, assim, transformar suas vidas. Há, desse modo, uma revalorização do papel da

${ }^{169}$ Veja-se a este propósito os livros de Bastide (1971; 1974). 
mulher, pois o fato de poder ser mãe e não só num sentido carnal, é o valor supremo, e é através de parir filhos que assegura-se a continuação da vida e da tradição.

No candomblé e na vida dessas mulheres há um outro ponto de força: a vivência do sagrado no cotidiano. Não se trata de um deus distante que mora no céu. Os orixás vivem com e nas pessoas e descem periodicamente para trazer conforto e axé. O mundo do sagrado não é algo de difícil acesso, ou alcançável somente através de um mediador especial, o padre. No percurso ritual, no entanto, há todo um processo que leva as mulheres a acreditarem sempre mais na própria intuição e na própria experiência, pois elas são uma parte do divino e tornam-se deusa ou deus em determinadas circunstâncias. Tal experiência de entrar em transe e de saber-se ser um cavalo do deus faz a própria pessoa adquirir uma grande importância. O cotidiano não é mais algo ameaçador, pois elas sabem das dificuldades que podem encontrar e acreditam em suas intuições e na ajuda do sobrenatural. O dia, portanto, é experimentado como algo de acolhedor, de bom, que deve ser trabalhado, tanto para si mesmas, quanto para o orixá, o que se torna um valor supremo.

Nesses depoimentos percebe-se que a religião desempenha um papel fundamental de organização e de orientação de vida. É da religião que as mulheres de candomblé apreendem o próprio valor como mães, trabalhadoras, seres-no-mundo. Um mundo no qual cada um é chamado a agir conforme o próprio destino e a sua capacidade. Então a religião não consiste apenas numa série de princípios abstratos, mas em um conjunto de padrões corporificados ao longo do processo ritual, e nisso reside sua eficácia para se experiênciar e reorientar a própria vida e a dos outros. Cria-se assim uma cumplicidade entre mulheres que experimentaram os mesmos sentimentos e que passaram pelos mesmos rituais. Cumplicidade que não fica só dentro da própria comunidade, apesar de ter laços mais estreitos entre os irmãos e as irmãs-de-santo, mas abre-se aos outros seres humanos e enfim ao mundo, pois a vida pertence a todos. 


\section{CONCLUSÃo}

Apesar da grande influência que as tradições africanas tiveram no Brasil, o candomblé na Bahia é ainda percebido como algo "de baixo nível"; algo "muito ligado à terra", em que "as pessoas não conseguem ter um maior desenvolvimento espiritual ou mental", pois os de fora "não sabem o que significam os rituais" e ainda vêem essa religião como ligada a algo de perigoso. A despeito de avaliações negativas e preconceituosas, há no candomblé uma sabedoria diferente, fundamentada na junção das partes que formam o ser humano, numa dinâmica "dançante". No candomblé, o ser humano não é percebido como algo fixo, mas como um processo e um diálogo de várias partes que se entrelaçam num jogo dinâmico, um jogo em que se ligam as forças externas do macrocosmo.

No candomblé, portanto, é considerado sábio, de conhecimento, aquele que sabe lidar com a união dessas partes numa dinâmica que abra possibilidades e que não feche "os caminhos". Através de oferendas e rituais tudo pode ser reavaliado e renegociado com as divindades, inclusive as questões que dizem respeito ao mundo social ${ }^{170}$. Essa concepção é profundamente diferente daquela ocidental, segundo a qual os saberes tornam-se sempre mais diferenciados e fechados, faltando a visão do todo. Esse todo é percebido no candomblé - a partir de suas próprias premissas, é claro - e é para o todo que o processo ritual leva os fiéis.

O candomblé enquanto religião estrutura e organiza uma visão do mundo na qual o indivíduo está em harmonia com a natureza. Por isso, a religião reorienta as pessoas no seu "serno-mundo" e atribui valor especial às coisas, aos animais, às plantas e aos outros seres humanos; enfim, à própria comunidade, pois é desenvolvendo seu papel na sociedade que o indivíduo também se constrói e dinamiza.

O corpo é, de fato, o centro de todo o processo ritual no candomblé. Um corpo que não é rejeitado ou afastado como fonte de "pecado", mas algo de valor, como uma base firme sobre a qual cada um deve se apoiar com confiança. Através do processo ritual, os fiéis aprendem a dar valor ao seus sentimentos e às suas intuições, abrindo-se a um outro tipo de conhecimento que

${ }^{170}$ Sobre a função social das sociedades secretas entre os povos iorubás, ver Drewal (1992) e Lawal (1996). 
não se fundamenta só sobre o lado mental, mas sobre a experiência sensorial do corpo. $\mathrm{O}$ conhecimento se dá através da experiência do corpo, que não é simplesmente percebida como irracional ou de segundo nível, mas como algo que impulsiona a força vital que mantém e move o corpo humano.

Durante as diferentes etapas iniciáticas, as sacerdotisas do candomblé experimentam um processo do corpo, orgânico, no qual, por meio do sofrimento e da dor, conseguem alcançar um novo equilíbrio e uma nova força. Aprendem que não são mais sozinhas, mas amparadas por seu orixá e pela comunidade. No início, elas se defrontam com várias situações de perigo e de desequilíbrio, pois as percepções do corpo são pesadas e às vezes assustadoras, mas num segundo momento, a se estabelecer o vínculo da iniciada com o seu orixá pessoal, elas vão sentindo se equilibrarem as sensações e emoções, antes desordenadas e desconexas.

Esse "processo orgânico" leva os filhos-de-santo, ao prosseguirem no caminho místico, à feitura de santo, e então eles passam a dançar no ritual público: o transe passa a ser vivido como experiência fundamental. Podemos entender o transe como uma outra maneira de compreender o mundo que nos circunda; não há mais limite entre o interno e o externo, e o corpo habita o mundo no seu tempo e espaço. Pela possessão, que é uma reorganização dos princípios constitutivos da pessoa nos aspectos físico, mental e espiritual, o fiel se encontra com uma nova força dinâmica, que pode até mesmo em alguns casos curar doenças físicas e desequilíbrios mentais. No candomblé, como religiões de possessão, há um outro tipo de atenção e de sabedoria que é fundamentado no corpo e na procura da comunicação com os orixás. Há uma outra compreensão, mais sutil, que é baseada numa abertura maior para o "sentir", uma abertura dos sentidos.

A aprendizagem dos rituais dá-se através da interiorização de atos, palavras e gestos que não se apóia na leitura, mas na experiência da repetição, repetição que, não sendo algo de frio, permite um "ser-no-mundo" que penetra estavelmente nas coisas cotidianas, pois as representações dos caminhos místicos observam e utilizam os processos concretos do corpo e as técnicas da existência cotidiana. Nesse processo de constituição do conhecimento e do sentimento, a "presença" ameaçada consegue reagir e dinamicamente se reconstrói com técnicas e meios cotidianos ligados à cultura. Como dizia De Martino (1958), "a presença é estar presente no próprio horizonte histórico-existencial", significando, assim, que a presença é a vida e o seu movimento. Por isso o orixá, que é uma força viva, que dança no ritual, é "presente": ele age no mundo e nos mostra as suas ações, distribuindo o axé.

Conforme Prandi,

"É através do rito e do mito que cada um pode encontrar-se com uma identidade primal religiosamente descoberta e desvendada" (1991a: 24).

Essa identidade é o orixá dono da cabeça que acompanhará o fiel por toda a sua vida, amparando-o, protegendo-o ou até castigando-o, porque essa religião é uma religião de divindades-humanas que, como os seres humanos, experimentam as paixões. Assim, apreendendo a lidar com os orixás, o devoto apreende a lidar consigo mesmo e com a vida.

A arte presente nos rituais do candomblé, além de propiciar a fruição estética, serve para construir e chamar as energias dos orixás, pois acredita-se nas energias da natureza. 
Diferentemente do pensamento ocidental que inclui as energias como parte do nosso ambiente, para os fiéis do candomblé os orixás são energias reais, são "as coisas-em-si-mesmas". Há assim algumas técnicas como a música e a dança que constroem e abrem os "caminhos energéticos" para o orixá se manifestar no ritual. Assim, também a audição e a visão não são mais simplesmente o ouvir, o ver, mas uma ampliação de todos os sentidos para um "sentir" que abrange a realidade, o lado energético-espiritual.

A história do candomblé está ligada à história da escravidão e das mulheres negras. Apesar de haver nos candomblés várias pessoas brancas de classe média, a raiz provém da ancestralidade africana e da luta para se manter fiel à própria cultura e tradição. Assim, a tristeza e a depressão dos escravos foram transformadas pelas sacerdotisas e pelos sacerdotes do candomblé numa "nascente" de força, vida e alegria, pois sempre os fiéis relatam a passagem do sofrimento a uma nova visão da vida fundamentada numa consciência do corpo, nas suas percepções e na fé aos orixás.

As filhas-de-santo conseguiram ter e dar uma visão de continuidade de vida, pois encontraram um caminho para a própria vida que não é uma série de fragmentos, mas apóia-se numa tranqüilidade interior que provém de sua prática religiosa. O adepto encontra seu lugar na ordem da cosmovisão, no jogo dos conceitos, dos sons, das rezas, das danças, dos perfumes e dos ritmos. As mulheres de candomblé ao alcançarem os níveis hierárquicos na religião, assumem uma sabedoria que lhes permite desenvolver também os papéis sociais com mais segurança e dignidade, pois elas aprenderam a dar valor aos seus próprios orixás, que no final são elas mesmas, e a divindade transforma a vida.

A ligação com o sagrado continua no cotidiano, dá força e ajuda a enfrentar a vida, que é difícil e continua sendo, agora até com mais obrigações a cumprir. A entrada do sagrado no cotidiano, do extraordinário no ordinário, também permite a consciência de não ser só, mas de ter um amigo sagrado que ampara. Elas aprendem no cotidiano, na prática das coisas, na escuta, que a vida continua e que apesar dos problemas e das dificuldades, há um fluxo de continuidade de existência desde o ancestral até o recém-nascido, seja no âmbito carnal seja no espiritual. As devotas têm consciência disso e do destino que deve ser cumprido, como afirma sempre a famosa Tia Cantu, "cada um tem seu destino a cumprir, eu já cumpri minha missão!". As mulheres de candomblé tornam-se orientadoras, pois percebe-se em suas palavras uma experiência de vida "verdadeira"; não são palavras vazias, por trás têm o valor da experiência e da continuidade da vida, pois enxergam os problemas das pessoas dentro de uma ordem na qual cada pessoa e coisa adquire um valor e um significado. Há uma grande simplicidade atrás deste mundo, simplicidade que não significa "coisa de pouco", mas uma compreensão do mundo nas suas coisas-em-si.

O papel central da mulher nas casas de tradição queto provém de sua condição de mãe e provedora, daquilo que materialmente dá continuidade à vida e à descendência, como Iemanjá ou Oxum. Ela também é uma mulher que luta e guerreia contra os inimigos por sua própria liberdade, como Oiá na mitologia encarnada pelos orixás que dançam. Quando, na Bahia, se fala em "ser escravo do orixá", o sentido é o de "ser servidor do orixá", de ser aquela pessoa que foi escolhida para caminhar segundo às vontades do deus. É a religião se auto-justificando. 
Assim, esses e essas crentes que adotam tal visão de mundo conseguem "produzir um sentido" e dar sentido aos seus corpos, pois é ele o lugar onde se mostra o sentido. 


\section{BIBLIOGRAFIA}

ABIMBOLA, Wande. The Yoruba Concept of Human Personality. In: CNRS. La notion de personne en Afrique Noire. Paris, Centre National de la Recherche Scientifique, 1973.

ABIODUN, Rowland. Woman in Yoruba Religious Images. African Languages and Cultures 2,1: 1-18, 1989.

. Understanding Yoruba Art and Aesthetics. The Concept of Ase. African Art, vol.XXVII, no.3, 1994.

ADESANYA, Adebayo. Yoruba Metaphysical Thinking. Odu, 5, Ibadan, Nigéria, 1958.

ÁJÀYÍ, Omófolábò. Yoruba Dance. Quebec, Canadá, African World Press, 1998.

ASANTE, K. Welsh. Commonalities in African Dance: an Aesthetic Foundation. Rhythms of Unity. Wesport, Connecticut, Greenwood Press, 1985. . African Dance. Canadá, Quebec, African World Press, 1998.

AUGRAS, Monique. O duplo e a metamorfose. Petrópolis, Vozes, 1983.

. Un pluriel singulier: la construction de la personne dans le candomblé. Societés, 21:29-31, 1988.

. A cozinha sagrada. Rio de Janeiro, (mimeo), 1994.

BACHOFEN, Johann. Il Matriarcato. In: Moretti, Dal simbolo al mito. Milão, Spirali, 1983.

BARBÁRA, Rosamaria Susanna. A dança do vento e da tempestade. Dissertação de Mestrado em Ciências Sociais. Salvador, UFBA, 1995.

. La letteratura orale ioruba: gli oriki. In: FALDINI, Luisa (org.). Religione e magia: culti di possessione in Brasile. Turim, Utet, 1997.

. Storie di Bahia. Milão, Mondadori, 1999.

. A dança sagrada do vento. In: Martins \& Lody (org.). Faraimará - o caçador traz Alegria. Rio de Janeiro, Pallas, 1999. 
BARNES, Sandra (org.). Africa's Ogun: Old World and New. Bloomington \& Indianapolis, Indiana University Press, 1989.

BARROS, José Flávio de \& TEIXEIRA, Maria Lina Leão. O código do corpo: inscrições dos orixás. In: MOURA, Carlos Eugênio Marcondes de (org). Meu sinal está no seu corpo, São Paulo, Edicon/Edusp, 1989.

BASTIDE, Roger. Les Amériques noires. Paris, Payot, 1967.

. Sogno, trance e follia. Milão, Jaca Book, 1974.

. Cavalos dos santos. In: Estudos afro-brasileiros. São Paulo, Editora Perspectiva, 1974.

. (org). Schiava: la donna di colore in america Latina. Milão, Mazzotta, 1977.

. O candomblé da Bahia (Rito nagô). São Paulo, Nacional, 1978.

. Le principe d'individuation: contribution à une philosophie africaine. In: La Notion de personne en Afrique Noire, Paris, CNRS, n. 544, 1973.

. As religiões africanas no Brasil. São Paulo, Pioneira, 1985.

BATTISTRADA, Franco. Per un umanesimo rivisitato. Milão, Jaca Book, 1999.

BAUDIN, P. Fétichisme et féticheurs. Lyon, Seminaire des Mission Africaines, 1884.

BENISTE, José. Orun Aiyé, o encontro de dois mundos. Rio de Janeiro, Bertrand Brasil, 1997.

BERNARDO, Teresinha. A mulher no candomblé e na umbanda. Dissertação de Mestrado em Antropologia, São Paulo, PUC, 1986.

BETTELHEIM, B. Truants from Life. Illinois, The Free Press, 1954.

BIRMAN, Patricia. Fazendo estilo, criando gênero. Rio de Janeiro, Editora da UERJ, 1995.

BLACKING, John. The Anthropology of the Body. London, Academic Press, 1977.

BOAS, Franz. Dance and Music in the Life of the Northwest Coast Indians of North America. In: BOAS, Franziska (org). The Function of Dance in Human Society, New York, The Boas School, 1944.

BODDY, Janice. Spirit Possession Revisited: beyond Instrumentality. Annual Review of Anthropology, vol. 23: 407-434, 1994.

BOURDIEU, Pierre. Outline of a Theory of Practice. Cambridge, Cambridge University Press, 1977.

BOURGUIGNON, Erika. Trance Dance. Dance Perspective, nº 35, 1968.

Possession. São Francisco, Chandler and Sharp, 1976.

BRAGA, Julio. O jogo de búzios: um estudo de adivinhação no candomblé. São Paulo, Brasiliense, 1988.

. Contos afro-brasileiros. Salvador, Empresa Gráfica da Bahia, 1989.

. Ancestralidade afro-brasileira. Salvador, Ianamá, 1992.

BRELICH, Angelo. Introduzione alla storia delle religioni. Roma, Edizioni Dell' Ateneo, 1975. 
BRITO POLVORA. O Corpo Batuqueiro. In: FACHEL LEAL, Ondina (org). O corpo e o significado. Porto Alegre, UFRGS, 1995.

CABRERA, Lydia. Piante e magia. Milão, Rizzoli, 1984. . Yemayá y Ochún. Madri, C\&R, 1974.

CALAME-GRIAULE, Genevieve. Il mondo della parola: etnologia e linguaggio dei dogon. Turim, Boringhieri, 1982.

CARYBÉ. Iconografia dos deuses africanos no candomblé da Bahia. São Paulo, Raízes Artes Gráficas, 1980.

CARNEIRO, Edison. Candomblés da Bahia. Rio de Janeiro, Civilização Brasileira, 1947. . Religiões negras. Rio de Janeiro, Civilização Brasileira, 1981.

CARVALHO, José Jorge de. Ritual and Music of the Sango Cults of Recife, Brazil. Ph.D. Thesis. Belfast, the Queen's University (mimeo), 1984.

CHERCI e CHERCI. Ernesto De Martino. Nápolis, Liguori, 1987.

CHERNOFF MILLER, John. African Rhythm and African Sensibility. Chicago, University of Chicago, 1979.

CONNERTON, Paul. Como as sociedades recordam. Oeiras, Celta Editora, 1993.

CONSORTE, Josildeth Gomes. Em torno de um manifesto de ialorixás baianas contra o sincretismo. In: CAROSO, Carlos e BACELAR, Jeferson (orgs.), Faces da tradição afrobrasileira. Rio de Janeiro, Pallas, 1999.

COSSARD-BINON, Giséle. Contribution a l'étude des candomblés au Brésil: le candomblé angola. Paris, Doctorat de Troisième Cycle (mimeo)/ Faculté des Lettres et Sciences Humaines, 1970.

A filha-de-santo. In: MOURA, Carlos Eugênio Marcondes de (org). Olóòrisa: escritos sobre a religião dos orixás. São Paulo, Ágora, 1981.

COURLANDER. Le danze di Haiti. In: BOAS. F. (org.). La funzione sociale della danza. Milão, Savelli, 1981. (tit. orig. In: BOAS Franziska (org). The Function of Dance in Human Society. New York, The Boas School, 1974).

CSORDAS, Thomas. Embodiment and Experience. The Existencial Ground of Culture and Self. Cambridge, Cambridge University Press, 1990.

. Somatic Modes of Attention. Cultural Anthropology, vol. 8, n.2: 135-156, 1993.

. Embodiment as a Paradigm for Anthropology. Ethos, vol.18: 5-47, 1994.

CUNHA, Marlene. Em busca de um espaço. São Paulo, Dissertação de Mestrado em Antropologia/ USP, 1986.

D'ARCAIS, P. L'individuo libertario. Turim, Einaudi, 1999.

DANIEL, Yvonne. Dance and Social Change in Contemporary Cuba. Bloomington \& Indianapolis, Indiana University Press, 1995.

DANTAS, Beatriz Góis. Repensando a pureza nagô. Religião e Sociedade, n. 8:15-20 julho 1982. 
DAVIDSON, Basil. La civiltá africana. Turim, Einaudi, 1972. (tit. orig. The Africans. An Entry to Cultural History. Londres, Longmans, Green and Co., 1969).

DE AZEVEDO SANTOS, Maria Stella. E aí aconteceu o encanto. Salvador, Axé Opô Afonjá, 1988. . Meu tempo é agora. São Paulo, Oduduwa, 1993.

DE MARTINO, Ernesto. Il mondo magico. Turim, Boringhieri, 1973. [1 ${ }^{\text {a }}$ ed. 1948].

. Morte e pianto rituale nel mondo antico: dal lamento pagano al pianto di Maria. Turim, Boringhieri, 1983. [1 ${ }^{\mathrm{a}}$ ed. 1958].

. Sud e magia. Milão, Feltrinelli, 1959.

. La fine del mondo. Turim, Einaudi, 1977.

. La terra del rimorso. Milão, Il Saggiatore, 1994. [1ª ed. 1961].

DEREN, Maya. I cavalieri divini del vudu. Milão, Il Saggiatore, 1997.

DI CRISTOFARO LONGO, Gioia. Centralità del ruolo della donna nella trasmissione della cultura. In: MANCA, Di Cristofaro longo, Donne e cultura. Roma, Ave, 1995.

DOUGLASS, Mary. Natural Symbols. Londres, The Cresset Press, 1970.

DREWAL, THOMPSON, Margaret. Yoruba Ritual: Performers, Play, Agency. Bloomington \& Indiana, Indiana University Press, 1992.

DURKHEIM, Emile. As formas elementares da vida religiosa. São Paulo, Paulinas, 1989.

. De quelques formes primitives de classification. L'année sociologique, Paris, 1901/1902.

EDUARDO, Octavio da Costa. The Negro in Northern Brazil. Seatle, University of Washington Press, 1948.

ELIADE, Mircea. O mito do eterno retorno. Lisboa, Edições 70, 1969.

. Trattato di storia delle religioni. Turim, Boringhieri, 1976.

. O sagrado e o profano. São Paulo, Martins Fontes, 1995.

. Lo sciamanismo e le tecniche dell'estasi. Roma, Mediterranee, 1999.

ELLIS, A. The Yoruba-Speaking People of the Slave Coast of West Africa. London, Curzon Press, 1974.

ENGELS, F. L'origine della famiglia, della proprietà privata e dello stato. Roma, Editori Riuniti, 1993.

EVANS-PRITCHARD, Edward. The Dance. Africa, i:446-62, 1928.

. I nuer. Milão, Angeli, 1975.

FADIPE, N. A .The Sociology of the Yoruba. Ibadan, Nigéria, Ibadan University Press, 1970.

FALDINI, Luisa (org.). Religione e magia: culti di possessione in Brasile. Turim, Utet, 1997.

FERREIRA, Luis. Los tambores del candomblé. Montevideo, Ediciones Colihue-Sepé, 1997. 
FERRETTI, Sergio. Querebentan de Zomadônu. Etnografia da Casa das Minas do Maranhão. São Luís, Universidade Federal do Maranhão, 1996.

FINNEGAN, R. Drum, Language and Literature. In: Oral Literature in Africa. Nairobi, Oxford University Press, 1977.

FRIEDSON, Steven. Musical Experience in Tumbuka Healing. Chicago \& London, The University of Chicago Press, 1996.

GADAMER, H. G. Verdade e método. Petrópolis, Vozes,1997.

GALIMBERTI, Umberto. Il corpo. Milão, Feltrinelli, 1987.

GENNEP, Arnold van. The Rites of Passage. London, Routledge and Kegan Paul, 1960. [1 ${ }^{\mathrm{a}} \mathrm{ed}$. 1909].

GEERTZ, Cliford. A interpretação das culturas. Rio de Janeiro, Zahar Editores, 1978.

GORER, Geoffrey. La funzione delle danze nelle comunità africane primitive. In: BOAS. F (org). La Funzione sociale della danza, Milão, Savelli, 1981. (tit, orig. In: BOAS, Franziska (org.) The Function of Dance in Human Society, New York, The Boas School, 1944).

GLEASON, Judith. In Praise of the Goddess. Boston, Shambhala, 1987.

GOLDMAN, Márcio. A construção ritual da pessoa: a possessão no candomblé. In: MOURA, Carlos Eugênio Marcondes (org.). Candomblé desvendando identidades. São Paulo, EMW Editores, 1987.

GOODMAN, Felicitas. How About Demons?: Possession and Exorcism in the Modern World. Bloomington \& Indianapolis, Indiana University press, 1988.

GROTTANELli, Cristiano; CLEMENTE, Pietro; DEI, Fabio e SIMONICCA, Alessandro. Discussione su storia notturna. Quaderni di storia. Roma, anno XVII:103-129, n.34, luglio-dicembre 1991.

GUÉNON, René. Simboli della scienza sacra. Milão, Adelphi, 1992.

GUYTON, Arthur. Trattato di fisiologia medica. Pádua, Piccin Nuova Libraria, 1987.

HALL, Edward. Proxemics. Current Anthropology, 9, 1968.

HANNA, Judith. African Dance as Education. Impulse, 48-56, 1965 a.

. African's New Traditional Dance. Ethnomusicology IX: 13-21, 1965 b.

. The Status of African Dance Studies. Africa, 36 (3): 303-07, 1966.

HARDING, RACHEL. A Refuge in Thunder: Candomblé and Alternative Spaces of Blackness. Bloomington \& Indianapolis, Indiana University Press, 2000.

HEALEY, Mark. Os desencontros da tradição em "Cidade das mulheres": raça e gênero na etnografia de Ruth Landes. Cadernos Pagu, (6-7): 153-200, 1996.

HEIDEGGER, Martin. Essere e tempo. Milão, Longanesi, 1976.

. The Question Concerning Technology and Other Essay. New York, Harper Colophon Books, 1977. 
HERSKOVITS, MELVILLE J. The Myth of the Negro Past. New York, 1941.

. Drums and Drummers in Afro-Brazilian Cult Life. The musical quarterly, XXX, 4: 477492, 1944.

. The City of Women. Book Review. Northwestern University Evanson, Illinois, 1947.

. The Panan. Les afro-américains, M. IFAN, n.27: 133-140, Dakar, 1952.

HOLT AND BATESTON. Forma e função da dança em Bali. In: BOAS, Franziska (org.). The Function of Dance in Human Society, New York, The Boas School, 1944.

IDOWU, E. Bolaji. Olódùmarè: God in Yoruba Belief. New York, Original Publications, 1995.

JACKSON, M. Introduction. Phenomenology, Radical Empiricism, and Anthropological Critique. In: JACKSON, M. (ed). Things as they are: New Directions in Phenomenological Anthropology. Bloomington, Indiana University Press, 1996.

JANH, John. Muntu, La civiltá africana moderna. Turim, Einaudi, 1975. (Tit.orig. Umrisse der neoafrikanischen Kultur. Dusseldorf, Eugen Diederichs Verlag, 1958).

JOHNSON, Rev. Samuel. The History of the Yorubas. Lagos, Nigéria, C.M.S. Bookshop, 1956.

JONES, A. Studies in African Music. London.v.1-2., 1959.

JUNG, Carl Gustav e KERÉNYI, Karl. Prolegomeni allo studio della mitologia. Turim, Einaudi, 1948.

KAEPPLER, Adrienne. Folclore as Expressed. In: The Dance in Tonga. JAF 80 (316): 160-68, 1967a.

. The Structure of Tongan Dance. University of Hawaii, Ph.D. Dissertation (Antropology), $1967 \mathrm{~b}$.

KAPFERER, Bruce. Introduction: Ritual Process and the Transformation of Context. Social Analysis, 1: 3-19, 1979a.

. Entertaining Demons. Social Analysis, 1:108-152, 1979b.

. A Celebration of Demons: Exorcism and Aesthetics of Healing in Sri Lanka. Oxford, Berg Publishers, 1991.

. Entertaining Demons: Comedy, Interaction and Meaning in a Singalese Healing Ritual. Social Analysis n.1: 102-152, February, 1979.

KEALIINOHOMOKU, Joann. A Comparative Study of Dance as a Constellation of Motor Behaviors among African and United States Negroes. Northwest University, M.A. thesis (Anthropology), 1965.

. Hopi and Polynesian Dance: a Study in Cross Cultural Comparisons. Ethnomusicology XI (3): 343-357, 1969 ..

. Field Guides. In: Tamara Comstock, org. New Dimensions in Dance Research: Anthropology and Dance. pp. 245-60. New York, Committee on Research in dance, 1974b.

KOGAN, Ainda Aisenson. Cuerpo y persona: filosofia del cuerpo vivido. México, Fondo de Cultura Económica, 1981. 
KUBIK, Gerhard. Angolan Traits in Black Music, Games and Dances of Brazil: a Study of African Cultural Extensions Overseas. (Estudos de Antropologia Cultural, n.10). Lisboa, Junta de Investigações do Ultramar, 1979.

KURATH, Gertrude. Dance: Folk and Primitive. In: LEACH M. \& Fried J., Standard Dictionary of Folklore, Mythology and Legend. New York, Funk \& Wagnalls, 1949 a.

. A Choreographic Questionnaire. Midwest Folklore, 2: 53-55, 1952 a.

. Choreology and Anthropology. AA 58: 177-179, 1956 a.

. Panorama of Dance Ethnology. Current Anthropology, 1 (3): 233-254, 160.

LABAN, Rudolf. Principles of Dance and Movement Notation. New York, Dance Horizons, 1956.

. Dominio do movimento. (Language of the Movement, A Guide Book to Choreology). São Paulo, Summus, 1978.

LANDES, Ruth. A cidade das mulheres. Rio de Janeiro, Civilização Brasileira, 1967, [1 ${ }^{\text {a }}$ ed. 1947].

. A Cult Matriarchate and Male Homosexuality. Journal of Abnormal Psychology. julho, 1940.

LANGER, Susan. Sentimento e forma, São Paulo, Perspectiva, 1980. (Tit.orig. Feeling and Form, 1953).

LAPASSADE, Georges. Saggio sulla transe. Milão, Feltrinelli, 1990.

LAWAL, Babatunde. A arte pela vida: a vida pela arte. Afro-Ásia, no 14, 1983.

. The Gèlèdé Spectacle: Art, Gender, and Social Harmony in an African Culture. Seattle e Londres, University of Washington Press, 1996.

. The Search for Identity in Contemporary Nigerian Art. Studio International, 193, $\mathrm{n}^{\circ} 2$, 193: 145-150, 1996.

LEACH, Edmund. Cultura e comunicação. Rio de Janeiro, Zahar, 1978.

LEAL FACHEL, Ondina. Corpo e significado. UFRGS, 1995.

LEENHARDT, M. Do Kamo: la personne et le mythe dans le monde mélanésien. Paris, Gallimard, 1947.

LE BRETON, David. Antropologia del cuerpo y modernidad. Buenos Aires, Nueva Visión, 1992.

LEIRIS, Michel. La possessione e i suoi aspetti teatrali tra gli etiopi di Gondar. Milão, Ubulibri, 1988. [1 ${ }^{\mathrm{a}} \mathrm{ed}$. 1958].

LEITE, Fábio. A questão ancestral: notas sobre ancestralidade e instituições ancestrais em sociedades africanas iorubá, agni, senufo. São Paulo, USP (Tese de Doutorado em Sociologia), 1983.

. Valores civilizatórios em sociedades negro-africanas. África, 18-19 (1): 103-117, 1995 1996. 
LÉPINE, Claude. Contribuição ao estudo da classificação dos tipos psicológicos no candomblé Ketu de Salvador. São Paulo, USP (Tese de Doutorado em Antropologia), 1978.

- Os estereótipos da personalidade no candomblé nagô. In: MOURA, Carlos Eugênio Marcondes de (org.). Olóòrisa: escritos sobre a religião dos orixás. São Paulo, Ágora, 1981.

LEROI-GOURHAN, Albin. Il gesto e la parola. Turim, Einaudi, 1977. (Tit. orig. Le geste et la parole, Paris, 1964).

LÉVI-STRAUSS, Claude. Mythologiques IV: l' homme nu. Paris, PUF, 1971.

Introduzione all'opera di Marcel Mauss. Sociologia e antropologia. São Paulo, Pedago, 1974.

LEWIS, Ioan M. Le religioni Estatiche. Roma, Ubaldini, 1972.

LIMA, Vivaldo da COSTA. A família de santo nos candomblés jêje-nagôs da Bahia: um estudo de relações intra-grupais. Salvador, UFBA (Dissertação de Mestrado), 1977.

. Os obás de Xangô. In: MOURA, Carlos Eugênio Marcondes de (org.). Olóòrìsa: escritos sobre a religião dos orixás. São Paulo, Ágora, 1981.

. O conceito de "nação" dos candomblés da Bahia. Afro-Ásia. Salvador, nº 12: 65-90, 1976.

- Organização do grupo de candomblé: estratificação, senioridade e hierarquia. In: MOURA, Carlos Eugênio Marcondes de (org.). Bandeira de Alairá: outros escritos sobre a religião dos orixás. São Paulo, Livraria Nobel, 1982.

- Nações de candomblé. In: Encontro de nações de candomblé. Salvador, Centro de Estudos Afro-Asiático da UFBA e Ianamá, 1984.

LODY, Raul. O povo do santo: religião, história e cultura dos orixás, vuduns, inquices e caboclos. Rio de Janeiro, Pallas, 1995.

LOMAX, Alan. Folk Song Style and Culture. Washington DC, American Association for the Advancement of Science (Publication 88), 1968.

. Choreometrics and Ethnographic Filmmakers. Filmmakers Newsletter, 4 (4): 31-38, 1971.

LOWEN, A. La spiritualità del corpo. Roma, Astrolabio, 1991.

LOSPINOSO, Marrianita. Circuiti femminili; autenticità, ambiguità e scambi nei rapporti di terreno. In: DI CRISTOFARO LONGO, Gioia e MARIOTTI, Luciana, Etnografia al femminile. Roma, Armando, 1998.

LÜHNING, Angela. Die Musik im Candomblé Nagô-Ketu: Studien zur Afrobrasilianischen Musik in Salvador, Bahia. In: Beiträge zur Ethnomusikologie, $\mathrm{n}^{\circ}$ 24, Hrsg. J.Kuckertz Musikverlag Karl Dieter Wagner, Hamburg, 1990a.

Música: coração do candomblé. Revista USP, no 7: 115-124, set-nov, 1990.

. O Mundo fantástico dos erês. Revista USP, nº 18: 92-97, 1993.

. Música no candomblé da Bahia: Cânticos para dançar. Quarto Simpósio de Musicologia Latino-Americana (no prelo), Curitiba, 2000. 
LUZ, Marco A. Agadá: dinâmica da civilização africano-brasileira. Salvador, Centro Editorial e Didático da UFBA e SECNEB, 1995.

MALHEIROS, P. A escravidão no Brasil: ensaio histórico-jurídico-social. Rio de Janeiro, Ed. Cultura, 1944.

MARCEL, G. Etre et avoir. Paris, Aubier, 1953.

MARCHIANÓ, Grazia. La parola e la forma. Bari, Dedalo, 1977.

MARINO, Roberval. Arte e educação no universo cultural nàgó: O Ilé Àse Opó Afonjá. Um estudo de caso de 1977 a 1988. São Paulo, USP (Tese de Doutoramento em Comunicação), 1989.

MARIOTTI, Luciana. Bambole e Donne artiste in Amazzonia. In: DI CRISTOFARO LONGO, Gioia e MARIOTTI, Luciana, Etnografia al femminile. Roma, Armando, 1998.

MARTIN, Gyorgy \& PESOVAR, Erno. A Structural Analysis of the Hungarian Folk Dance. Acta Ethnografica Academiae Scientiarum Hungaricae, X (1-2), 1961.

MARTINS, Suzanna. A study of the dance of Iemanjá. Dissertation to the Temple University, 1995.

MAUSS, Marcel. Il manuale d'etnografia. Milão, Jaca Book, 1972. . Sociologia e antropologia, vol.II. São Paulo, Pedago, 1974.

MERLEAU-PONTY, Maurice. L'institution dans l'histoire personnelle et publique. In: MerleauPonty, Résumés de cours (Collège de France, 1952-1960). Paris, Gallimard, 1968a.

. Le problème de la passivité: le sommeil, l'inconscient, la mémoire. In: Merleau-Ponty, Résumés de cours (Collège de France, 1952-1960). Paris, Gallimard, 1968b.

. Fenomenologia da percepção. São Paulo, Martins Fontes, 1994.

METRAUX, Alfred. Il vodu haitiano. Turim, Einaudi, 1971.

MINTZ, Sidney. I ruoli economici e la tradizione culturale. In: BASTIDE (org.). Schiava: la donna di colore in America Latina, Milão, Mazzotta, 1977.

MOTTA, Roberto. Ruth Landes e os candomblés bantos. São Paulo, ANPOCS (mimeo), 1984.

NEHER, Andrew. A Physiological Explanation of Unusual Behavior in Ceremonies Involving Drums. Human biology, no 4: 151-160, 1962.

NASCIMENTO, Luis Claudio Dias do. Candomblé e Irmandade da Boa Morte. Cachoeira, Fundação Maria Cruz, 1999.

NEUMANN, Erich. La grande madre. Roma, Astrolabio, 1981.

NKETIA, Kwabena. The Music of Africa. New York, W. W. Norton \& Company, 1974.

OLIVEIRA, Altair B. Cantando para os orixás. Rio de Janeiro, Pallas, 1997.

OMARI, Mikelle S. From the Inside to the Outside: the Art of Candomblé. Los Angeles, University of California/ Monograph Series \# 24, 1990.

ORTIZ, R. La matrifocalité religieuse. Diogène 15, 1979.

OTTO, Rudolf. Il sacro. Milão, Feltrinelli, 1966. [1 ${ }^{\text {a }}$ ed. 1917]. 
PANDOLFI, Mariella. Itinerari delle emozioni. Milão, F. Angeli, 1991.

PÂQUES, Viviana. La religion des esclaves: recherches sur la confrérie marocaine des Gnawa. Bergamo, Moretti \& Vitali Editori, 1991.

PELOSINI, Gaetano. La magia della spirale: l'equilibrio totale in un ordine cosmico. Roma, Esoterica, 1994.

PIERUCCI, Flávio e PRANDI, Reginaldo. A realidade social das religiões no Brasil. São Paulo, Hucitec, 1996.

PLATONE. Gorgia. In: Opere. Bari, Laterza, 1973.

PRANDI, Reginaldo. Os candomblés de São Paulo: a velha magia na metrópole nova. São Paulo Hucitec e Edusp, 1991 a.

. A religião e a multiplicação do eu: transe, papéis e poder no candomblé. Revista USP, no 9, pp. 133-144, 1991 b.

- As artes da adivinhação: candomblé tecendo tradições no jogo de búzios. In: MOURA, Carlos Eugênio Marcondes (org). As senhoras do pássaro da noite. São Paulo, Edusp, 1994.

. Herdeiras do axé: sociologia das religiões afro-brasileiras. São Paulo, Hucitec, 1996.

- Referências sociais das religiões afro-brasileiras: sincretismo, branqueamento, africanização. In: CAROSO, Carlos e BACELAR, Jeferson (orgs.). Faces da tradição afro-brasileiras. Rio de Janeiro, Pallas, 1999 a.

. Conceitos de vida e de morte no ritual do axexê: tradição e tendências recentes dos ritos funerários no candomblé. In: MARTINS, Cleo e LODY, Raul. Faraimará, o caçador traz alegria. Rio de Janeiro, Pallas, 1999 b.

. Mitologia dos orixás. São Paulo, Companhia das Letras, 2000.

. O candomblé e o tempo: concepções de tempo, saber e autoridade da África para as religiões afro-brasileiras. Revista Brasileira de Ciências Sociais, nº 47, pp. 43-58, 2001 a.

. Exu, de mensageiro a diabo: sincretismo católico e demonização do orixá Exu. Revista $U S P, n^{\circ} 50$, pp. 46-65, 2001 b.

QUERINO, Manuel. Costumes africanos no Brasil. Rio de Janeiro, Civilização Brasileira, 1938.

RABELO, Miriam \& ALVES, Paulo \& Souza, Iara. Experiência de doença e narrativa. Rio de Janeiro, Fiocruz, 1999.

RABELO, Miriam, SOUZA, Iara. Vida vivida, vida contada: uma reflexão sobre a experiência do nervoso na trajetória de mulheres de classe trabalhadora em Salvador. XXIV Encontro ANPOCS, 2000.

RADCLIFFE BROWN, Alfred. The Andaman Islander. New York, The Free Press of Glencoe, 1964.

RAMOS, Artur. Pesquisas estrangeiras sobre o negro do Brasil. In: A aculturação negra no Brasil. Rio de Janeiro, Biblioteca Pedagógica Brasileira, 1942.

. Introdução à antropologia brasileira. Rio de Janeiro, Edições da C.e B., 1943. 
REIS, A. Escravidão \& invenção da liberdade. São Paulo, Brasiliense, 1988.

RIBEIRO, René. Cultos afro-brasileiros do Recife: um estudo de ajustamento social. Recife, Instituto Joaquim Nabuco, 1952.

RICOEUR, P. Tempo e narrativa. Tomo I. Campinas, Papirus, 1994.

ROCHA, Agenor MIRANDA. Caminhos de odu. Rio de Janeiro, Pallas, 1999.

RODRIGUES, Nina. Os africanos no Brasi. São Paulo, Nacional, 1935.

. O animismo fetichista dos negros bahianos. $2^{\text {a }}$ ed. Rio de Janeiro, Civilização Brasileira, 1935.

ROYCE ANNYA P. Field Guide for the Collection of Ethnic Dance. MS, 1969 b.

. The Anthropology of Dance. Bloomington, Indiana Unversity Press, 1980.

ROSALDO, M.e LAMPHERE, L. (org.) A mulher, a cultura, a sociedade. Rio de Janeiro, Paz e Terra, 1979.

ROUGET, Gilbert. Musica e transe. Turim: Einaudi, 1986.

SACHS, Curt. La storia della danza. Turim, Boringhieri, 1980. (1ª ed. New York, W. W. Norton, 1937).

SANTOS, Deoscoredes Maximiliano dos (Mestre Didi). História de um terreiro nagô, 2a. ed.. São Paulo, Max Limonade, 1988.

SANTOS, Juana Elbein dos Os nagô e a morte. Petrópolis, Vozes, 1977.

SARACENO, Chiara - PICCONE STELLA, Simonetta. Genere: la costruzione del femminile e del maschile. Bolonha, Il Mulino, 1996.

SARTRE, J.P. L' essere e il nulla. Milão, Il Saggiatore, 1953.

SEGATO, Rita. Santos e daimones. Brasília, Editora da UnB, 1995.

SENGHOR, L.S. L'esprit de la civilization ou les lois de la culture negro-africaine. Présence Africaine, $\mathrm{n}^{\circ}$ VIII/X: 60, Paris, 1956.

SIKIRU, Salami (King) A mitologia dos orixás africanos. São Paulo, Oduduwa, 1990.

SNYDER FULLER, A. The Dance Symbol. In: New Dimension in Dance Research: Anthropology and Dance. Tucson, The University of Arizona, 1972.

SODRÉ, Muniz e LIMA, DE Luís Felipe. Um vento sagrado. história de vida de um adivinho da tradição nagô-kêtu brasileira. Rio de Janeiro, Mauad, 1996.

STOLLER, P. Fusion of the Worlds: An Ethnography of Possession among the Sonhay of Niger. Chicago e Londres, The University of Chicago Press, 1989. . Sensuous Scholasrship. Philadelphia, University of Pennsylvania Press, 1997.

TAMBIAH, Stanley. The Magic Power of Words. Man 3 (2), 1968.

. A Performative Approach to Ritual Proceeding. The British Academy, v. LXV: 113-169, 1979.

TCHIMOU, Famedji-Koto. Langage de la danse chez les Dogons. Paris, L'Harmattan, 1995. 
THOMPSON, Robert Farris. African Art in Motion. Nacional Gallery of Washington DC, 1974. . Flash of the Spirit: African and Afro-American Art and Philosophy. New York, Random House, 1983.

TRINDADE, Liana. Exu, poder e perigo. São Paulo, Ícone, 1985.

TURNER, Turner. Bodies and Anti-bodies: Flesh and Fetish in Contemporary Social Theory. In: CSORDAS, T. (org). Embodiment and Experience: The Existencial Ground of Self and Culture. Cambridge, Cambridge University Press, 1994.

TURNER, Victor. The Forest of Symbols. Ithaca, Cornell University Press, 1967.

. The Ritual Process. Chicago, Aldine, 1969.

. Dramas, Fields and Metaphors. Ithaca, Cornell University Press, 1974.

. Revelation and Divination in Ndembu Ritual. Ithaca, Cornell University Press, 1975.

VALLADO, ARMANDO. O sacerdote em face da renovação do candomblé. In: CAROSO, Carlos e BACELAR, Jeferson (orgs.). Faces da tradição afro-brasileira. Rio de Janeiro, Pallas e CEAO, 1999.

. Iemanjá, a grande mãe africana do Brasil. Mito, rito e representação. São Paulo, USP (Dissertação de Mestrado em Sociologia), 2000.

VERGER, Pierre. Note sur le culte des Orisa et Vodun. Ifan-Dakar, Mémoire de L'Institut Français d'Afrique Noir, 1957.

. O estado de erê: papel desempenhado pelo estado de alheiamento durante a iniciação de iyawô nos cultos de orisha e vodun. Anais da Segunda Reunião de Antropologia, Bahia, 1955. Salvador, Sociedades Artes Gráficas, 1957.

. The Yoruba High God: a Review of the Sources. Odu, vol. 2: 19-40, Ibadan, 1964.

. Flux et reflux de la traite des nègres entre le Golf de Bénin et Bahia de Todos os Santos. Paris, Mouton, 1968.

. Trance and Convention in Nagô-Yoruba Spirit Mediumship. In: Spirit Mediumship and Society in Africa. Londres, Beattle and Middleton, 1969.

. Notion de personne et lignée familiale chez les Yoruba. In: CNRS. La notion de personne en Afrique Noire. Paris, Centre National de la Recherche Scientifique, 1973.

. Orixás. Salvador, Corrupio, 1981.

. A contribuição especial das mulheres ao candomblé no Brasil. In: Culturas africanas. Documentos da Reunião de peritos sobre "As sobrevivências das tradições religiosas africanas nas Caraíbas e na América Latina”, pp. 272-290. São Luís, 1985.

. Artigos. Tomo I, São Paulo, Corrupio, 1992.

. Grandeza e decadência do culto de Iyá-mi Òsòròngà entre os yoruba. In: MOURA, Carlos Eugênio Marcondes de, As senhoras do pássaro da noite, pp.13-71. São Paulo, Edusp, 1994. 
WATERMAN, Richard. African Influence on the Music of Americas: Acculturation in the Americas. Selected papers of the XXIX International Congress of Americanists, edit by Sol Tax, Chicago, 1952: 207-218.

. Role of Dance in Human Society. In: Focus on Dance II. Washington, DC., American Association for Health, Physical Education and Recreation, 1962.

WEBER, Max. Rejeições religiosas do mundo e suas direções. In: TRAGTEMBERG, Maurício (org.). Ensaios de sociologia. São Paulo, Victor Civita, 1974.

. L'etica protestante e lo spirito del capitalismo. Milão, BUR, 1996.

WHEATLEY, Joan. La cittá come símbolo: Saggi sull'ordinamento e sulla percezione dello spazio urbano nelle societá tradizionali. Brescia, Marcelliana, 1983.

WOORTMANN, Klass. A família das mulheres. Rio de Janeiro, Tempo Brasileiro/ CNPq, 1987. 